\title{
Paleocene Vertebrates from Jabal Umm Himar, Kingdom of Saudi Arabia
}

\section{U.S. GEOLOGICAL SURVEY BULLETIN 2093}

Prepared in cooperation with the Ministry of Petroleum and Mineral Resources, Jiddah, Kingdom of Saudi Arabia

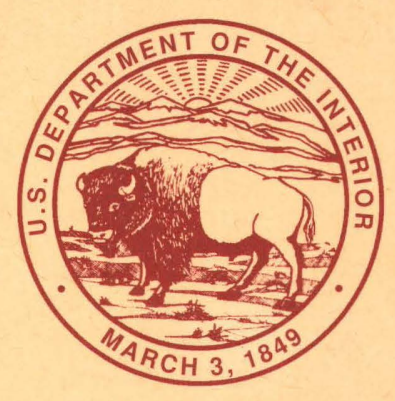




\section{AVAILABILITY OF BOOKS AND MAPS OF THE U.S. GEOLOGICAL SURVEY}

Instructions on ordering publications of the U.S. Geological Survey, along with prices of the last offerings, are given in the currentyear issues of the monthly catalog "New Publications of the U.S. Geological Survey." Prices of available U.S. Geological Survey publications released prior to the current year are listed in the most recent annual "Price and Availability List." Publications that may be listed in various U.S. Geological Survey catalogs (see back inside cover) but not listed in the most recent annual "Price and Availability List" may be no longer available.

Order U.S. Geological Survey publications by mail or over the counter from the offices given below.

BY MAIL

\section{Books}

Professional Papers, Bulletins, Water-Supply Papers, Techniques of Water-Resources Investigations, Circulars, publications of general interest (such as leaflets, pamphlets, booklets), single copies of Earthquakes \& Volcanoes, Preliminary Determination of Epicenters, and some miscellaneous reports, including some of the foregoing series that have gone out of print at the Superintendent of Documents, are obtainable by mail from

U.S. Geological Survey, Information Services

Box 25286, Federal Center, Denver, CO 80225

Subscriptions to periodicals (Earthquakes \& Volcanoes and Preliminary Determination of Epicenters) can be obtained ONLY from the

\section{Superintendent of Documents \\ Government Printing Office \\ Washington, DC 20402}

(Check or money order must be payable to Superintendent of Documents.)

\section{Maps}

For maps, address mail orders to

U.S. Geological Survey, Information Services

Box 25286, Federal Center, Denver, CO 80225

Residents of Alaska may order maps from

U.S. Geological Survey, Earth Science Information Center 101 Twelfth Ave. - Box 12

Fairbanks, AK 99701

\section{OVER THE COUNTER}

\section{Books and Maps}

Books and maps of the U.S. Geological Survey are available over the counter at the following U.S. Geological Survey Earth Science Information Centers (ESIC), all of which are authorized agents of the Superintendent of Documents:

- ANCHORAGE, Alaska-Rm. 101, 4230 University Dr.

- LAKEWOOD, Colorado-Federal Center, Bldg. 810

- MENLO PARK, California-Bldg. 3, Rm. 3128, 345 Middlefield Rd.

- RESTON, Virginia-USGS National Center, Rm. 1C402, 12201 Sunrise Valley Dr.

- SALT LAKE CITY, Utah-Federal Bldg., Rm. 8105, 125 South State St.

- SPOKANE, Washington-U.S. Post Office Bldg., Rm. 135, West 904 Riverside Ave.

- WASHINGTON, D.C.-Main Interior Bldg., Rm. 2650, 18th and C Sts., NW.

\section{Maps Only}

Maps may be purchased over the counter at the following U.S. Geological Survey offices:

- FAIRBANKS, Alaska-New Federal Bldg., 101 Twelfth Ave.

- ROLLA, Missouri-1400 Independence Rd.

- STENNIS SPACE CENTER, Mississippi-Bldg. 3101 


\section{Paleocene Vertebrates from Jabal Umm Himar, Kingdom of Saudi Arabia}

Edited by Frank C. Whitmore, Jr., and Cary T. Madden

U.S. GEOLOGICAL SURVEY BULLETIN 2093

Prepared in cooperation with the Ministry of

Petroleum and Mineral Resources, Jiddah,

Kingdom of Saudi Arabia

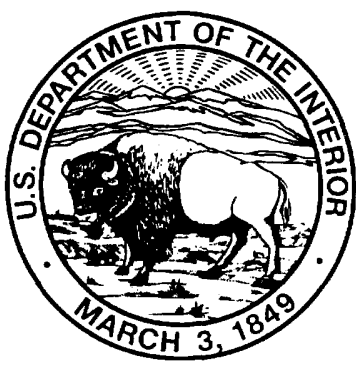

UNITED STATES GOVERNMENT PRINTING OFFICE, WASHINGTON : 1995 


\title{
U.S. DEPARTMENT OF THE INTERIOR BRUCE BABBITT, Secretary
}

\author{
U.S. GEOLOGICAL SURVEY \\ GORDON P. EATON, Director
}

For sale by U.S. Geological Survey, Information Services

Box 25286, Federal Center, Denver, CO 80225

\begin{abstract}
Any use of trade, product, or firm names in this publication is for descriptive purposes only and does not imply endorsement by the U.S. Government.
\end{abstract}

Published in the Eastern Region, Reston, Va.

Manuscript approved for publication April 14, 1994.

Library of Congress Cataloging in Publication Data

Paleocene vertebrates from Jabal Umm Himar, kingdom of Saudi Arabia / edited by Frank C. Whitmore, Jr., and Cary T. Madden.

p. $\quad$ cm. - (U.S. Geological Survey bulletin ; 2093A-F)

"Prepared in cooperation with the Ministry of Petroleum and Mineral Resources, Kingdom of Saudi Arabia."

Includes bibliographical references.

Supt. of Docs. no.: U19.3:2093A-F

1. Vertebrates, Fossil-Saudi Arabia. 2. Paleontology-Paleocene. I. Whitmore, Frank C., Jr. II. Madden, Cary T. III. Geological Survey (U.S.). IV. Saudi Arabia Wizārat al-Batrūl wa-al-Tharwah al-Ma'dinīyah. V. Series.

QE75.B9 no. 2093A-F

[QE841]

$557.3 \mathrm{~s}-\mathrm{dc} 20$

94-32990

[566.09538] 


\section{CONTENTS}

[Letters indicate the chapter.]

A. The Umm Himar Formation (Paleocene) of Saudi Arabia and Associated Strata: Stratigraphy, Vertebrate Fauna, and Paleoenvironment

By Cary T. Madden, Frank C. Whitmore, Jr., Dwight L. Schmidt, and Ibne Mohammed Naqvi

B. A Paleocene Percoid Fish, Tentatively Referred to the Family Serranidae, from Jabal Umm Himar, Kingdom of Saudi Arabia

By P.H. Greenwood

C. Paleocene Amiid Fish from Jabal Umm Himar, Kingdom of Saudi Arabia By Mark V.H. Wilson

D. A Paleocene Lungfish, Ceratodus humei Priem 1914, from Jabal Umm Himar, Kingdom of Saudi Arabia

By Frank C. Whitmore, Jr.

E. Paleocene Pelomedusid Turtles from Jabal Umm Himar, Kingdom of Saudi Arabia By Roger C. Wood

F. Dyrosaurs (Crocodilia, Mesosuchia) from the Paleocene Umm Himar Formation, Kingdom of Saudi Arabia

By Wann Langston, Jr. 



\section{The Umm Himar Formation (Paleocene) of Saudi Arabia and Associated Strata: Stratigraphy, Vertebrate Fauna, and Paleoenvironment}

By Cary T. Madden, Frank C. Whitmore, Jr., Dwight L. Schmidt, and Ibne Mohammed Naqvi

Prepared in cooperation with the Ministry of

Petroleum and Mineral Resources, Jiddah,

Kingdom of Saudi Arabia

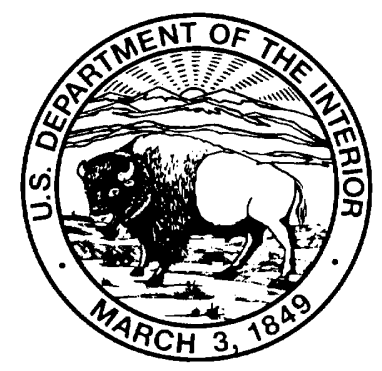




\section{CONTENTS}

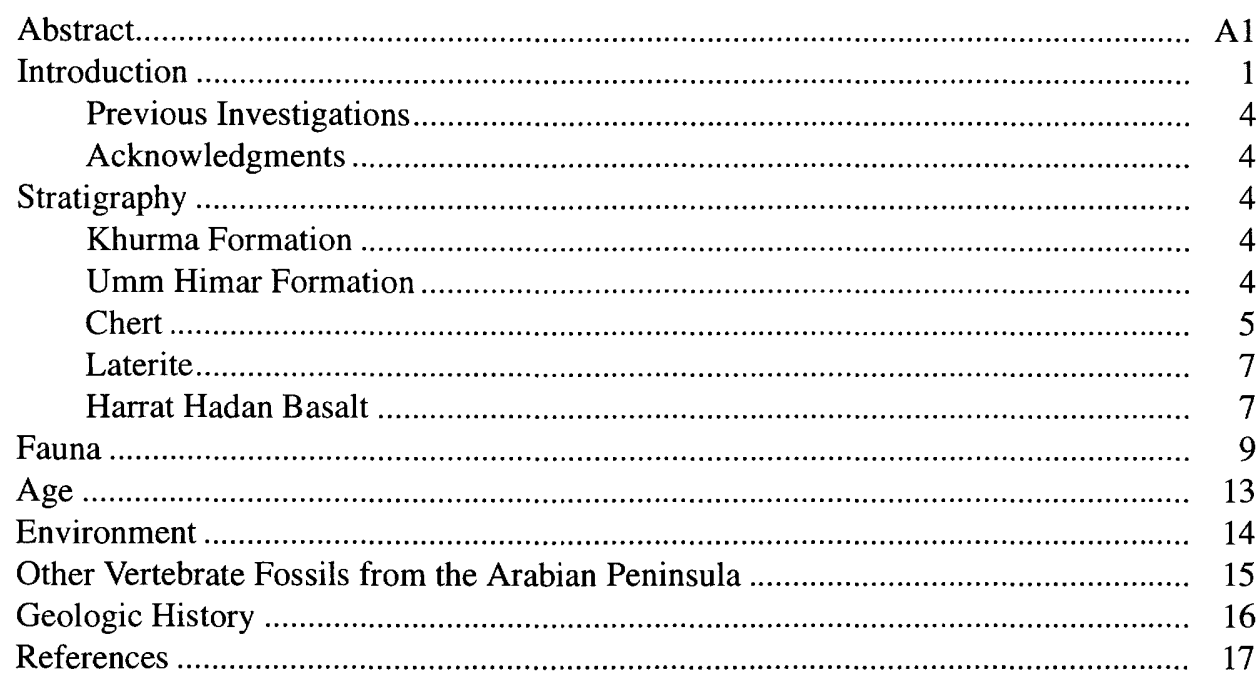

\section{FIGURES}

A1. Map of western Saudi Arabia, showing location of Jabal Umm Himar area .................................................. A2

A2. Geologic map of Jabal Umm Himar area, showing fossil localities .................................................................

A3. Stratigraphic sections measured at vertebrate fossil localities in the Jabal Umm Himar area ............................... 6

A4. Composite stratigraphic columnar section of Umm Himar Formation and overlying and underlying rocks in Jabal Umm Himar area

A5. Tertiary diagram showing composition of dolomitic limestone from the upper member of the Umm Himar Formation

A6. Diagram showing isotopic age plotted against $\mathrm{K}_{2} \mathrm{O}$ content for basaltic rocks from Harrat Hadan and other areas

\section{TABLES}

A1. Chemical analyses for $\mathrm{Fe}_{2} \mathrm{O}_{3}$ and $\mathrm{FeO}$ and semiquantitative spectrographic analyses for other elements in iron-oxide materials from the Jabal Umm Himar area

A2. Partial chemical analyses, in percent, for major elements of samples from the dolomitic limestone member of the Umm Himar Formation, Jabal Umm Himar area. The average of five samples of pisolitic laterite from nearby Jabal Saq is also given

A3. List of vertebrate fossils from the localities at Jabal Umm Himar. 


\title{
The Umm Himar Formation (Paleocene) of Saudi Arabia and Associated Strata: Stratigraphy, Vertebrate Fauna, and Paleoenvironment
}

\author{
By Cary T. Madden, ${ }^{1}$ Frank C. Whitmore, Jr., ${ }^{2}$ Dwight L. Schmidt, ${ }^{3}$ and Ibne Mohammed Naqvi ${ }^{4}$
}

\begin{abstract}
The first Paleocene vertebrate fauna known from the Arabian Peninsula is represented by fossils collected from 21 localities at Jabal Umm Himar, near Turabah, Southern Hijaz Province, Saudi Arabia. The fossils are from a mudstone, 2-3 meters thick, in the Umm Himar Formation. This formation, about 20 meters thick, consists of three members: (1) a basal ferruginous mudstone, (2) an interbedded mudstone and shale, from which the fossils were recovered, and (3) an upper dolomitic limestone. The Umm Himar Formation is underlain by Nubian-like quartzose sandstone, which overlies Precambrian rocks. The formation is overlain by the Harrat Hadan Basalt of late Oligocene and early Miocene age.

The vertebrates include sand sharks (Odontaspis substriata); nurse sharks (Ginglymostoma maghrebianum and G. sokotoense); eagle rays (Myliobatis dixoni); torpedos (Eotorpedo hilgendorfi); pycnodont fish (Pychodus); perch (Parapercichthys arabis); bowfins (Amiidae); catfish (Siluriformes); lungfish (Ceratodus humei); very large sidenecked turtles (Pelomedusidae); and archaic crocodilians (Rhabdognathus spp., Hyposaurus nopcsai, and Phosphatosaurus sp.). The Paleocene age determination for the fauna is based upon the stratigraphic ranges of the lungfish Ceratodus humei, the dyrosaurid crocodilians Rhabdognathus compressus and Hyposaurus nopcsai, and catfish (Siluriformes). Although not conclusive evidence of a Paleocene age, the sharks are consistent with this interpretation. The most nearly comparable fauna is that of the Dange Formation of Sokoto Province, Nigeria, whose age has been determined, on the basis of Foraminifera, to be late Paleocene.
\end{abstract}

'P.O. Box 1197, El Prado, NM 87529

${ }^{2}$ U.S. Geological Survey, Rm. E-308, NHB 137, Smithsonian Institution, Washington, D.C. 20560.

${ }^{3}$ U.S. Geological Survey, MS 913, Box 25046, Denver Federal Center, Denver, CO 80225-0046.

${ }^{4}$ U.S. Geological Survey Saudi Arabian Mission, P.O. Box 1488 , Jiddah, Saudi Arabia.
The paleoenvironment of Jabal Umm Himar was estuarine. The presence of a coastal environment indicates that at least a shallow sea must have existed in the At Taif region during the earliest Tertiary.

\section{INTRODUCTION}

Jabal Umm Himar ("hill of the mother of the donkey") is a large hill at lat $21^{\circ} 10^{\prime} \mathrm{N}$., long $41^{\circ} 25^{\prime} \mathrm{E}$., $100 \mathrm{~km}$ east of At Taif and $26 \mathrm{~km}$ west of Turabah, in the central western part of Saudi Arabia (fig. A1). An unimproved desert road connecting At Taif and Turabah crosses the Jabal Umm Himar area (fig. A2) in the Jabal In quadrangle (Gonzalez, 1973). All parts of the area are readily accessible by fourwheel-drive vehicle over the desert plain. The plain is at an altitude of about $1,200 \mathrm{~m}$ and small hills rise $10-50 \mathrm{~m}$ above it. The conspicuous basalt plateau of Harrat Hadan rises nearly $200 \mathrm{~m}$ above the desert plain in the northern part of the Jabal Umm Himar area.

In 1971 two fossil vertebrates were collected by Schmidt and Louis Gonzalez from a small wadi at locality 1 (fig. A2), $3.5 \mathrm{~km}$ northeast of Jabal Umm Himar. In 1974, the fossils were identified by Whitmore as representing a large member of the Mesosuchia, a widely distributed (Africa, Europe, Asia, North America, and South America) suborder of archaic crocodilians that originated in the Early Jurassic and became extinct in the late Eocene. Additional surface material was collected during October 1974 by Schmidt, T.H. Kiilsgaard, R.H. Blank, and N.E. Gettings.

The present report records the Paleocene vertebrates, stratigraphy, and environment of deposition in the Jabal Umm Himar area. This report is based upon paleontologic and geologic field investigations undertaken during JulyAugust 1976 and December-January 1978-79 (Madden and others, 1979). The fossils described in this bulletin constitute the first Paleocene vertebrate fauna known from the Arabian Peninsula.

Specimens discussed in this Bulletin have been assigned numbers with the prefix SAP (for Saudi Arabian Project) that identify them as to locality, higher taxon, and 


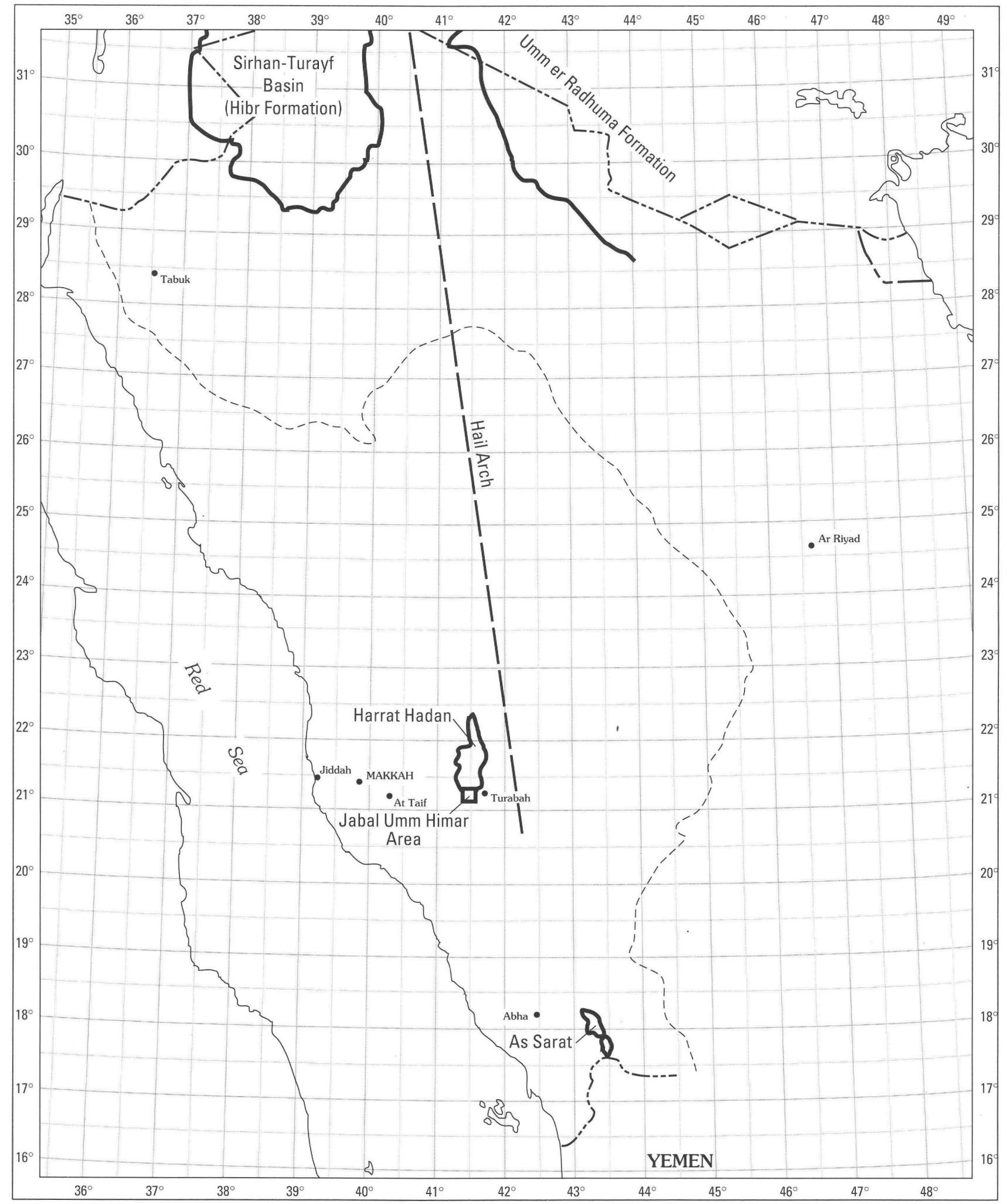

Figure A1. Index map of western Saudi Arabia, showing location of the Jabal Umm Himar area relative to the Hail Arch, the Sirhan-Turayf Basin, and other geologic features. 


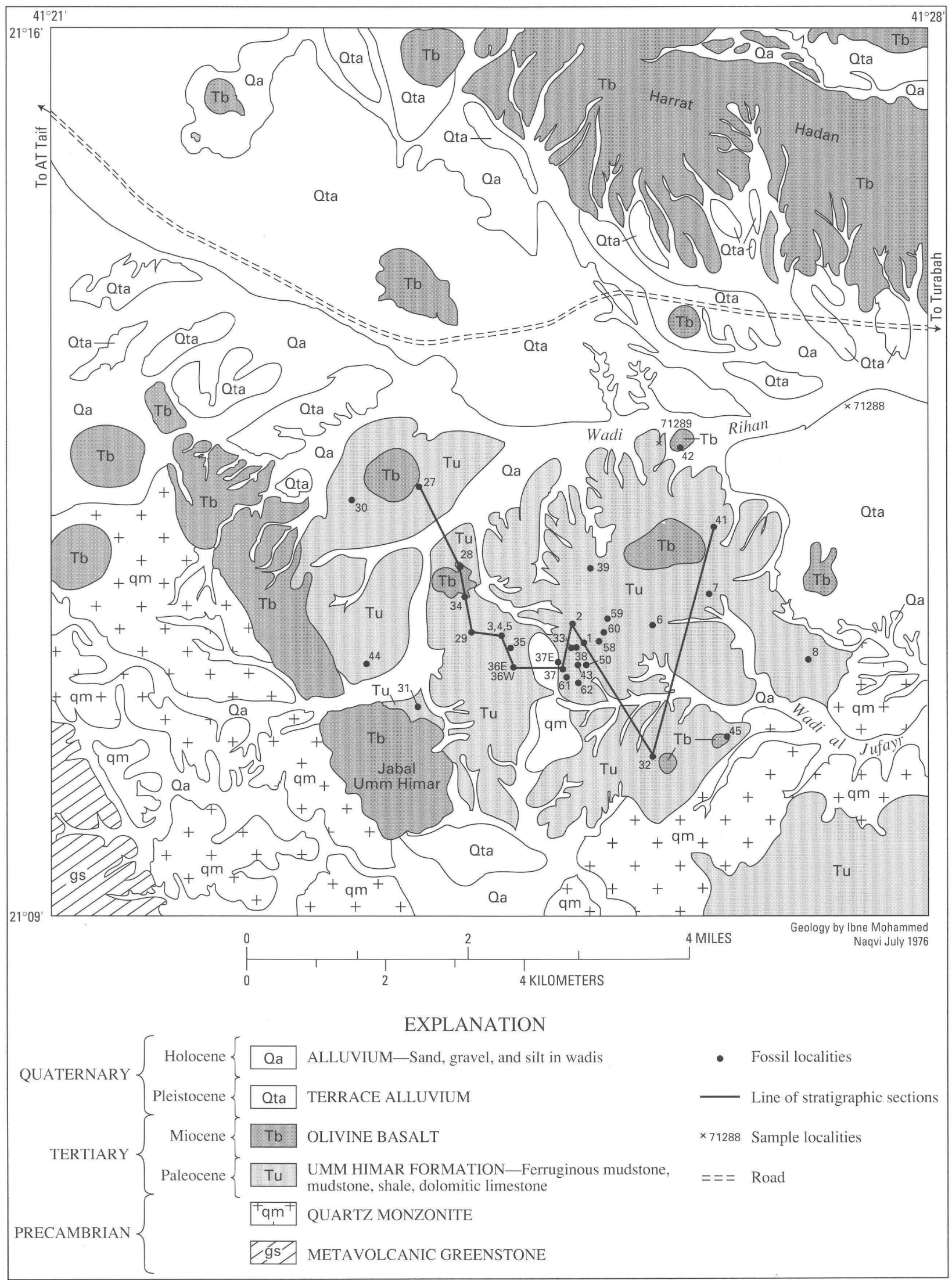

Figure A2. Geologic map of Jabal Umm Himar area, showing fossil sample localities and line of stratigraphic sections (fig. A3). 
specimen number within the taxon from a given locality. For example, SAP 33-CR-9 signifies the ninth crocodilian specimen from locality 33.

\section{PREVIOUS INVESTIGATIONS}

Brown and others (1963) mapped the region, including the Jabal Umm Himar area, as a part of the 1:500,000-scale map of the Southern Hijaz quadrangle. Baghanem (1972) described the geology of the Jabal Umm Himar area in a master's thesis for the South Dakota School of Mines and Technology. In 1970, Baghanem, then a geologist with the Directorate General of Mineral Resources (DGMR), Kingdom of Saudi Arabia, collected fossils including remains of turtles (order Chelonia) from the Jabal Umm Himar area. His fossils were the first collected from the area.

Gonzalez (1973) mapped and described the Umm Himar deposits as a part of the 1:100,000-scale map and report of the Jabal In quadrangle.

\section{ACKNOWLEDGMENTS}

Our field investigations were sponsored by the Directorate General of Mineral Resources, Ministry of Petroleum and Mineral Resources, Kingdom of Saudi Arabia, under an agreement with the U.S. Geological Survey (USGS). We had helpful discussions about the paleontology and geology of Jabal Umm Himar with A.H. Baghanem, W.A. Berggren, Eric Buffetaut, G.F. Brown, Richard Estes, the late F.J. Fitch, L.B. Halstead, D.G. Hadley, the late J.H. Hanley, the late W.R. Hamilton, Nicholas Hotton III, Roman Karpoff, G.E. Mayer, T.H. Kiilsgaard, M.J. Novacek, R.W. Purdy, L.F. Rooney, F.S. Simons, N.F. Sohl, I.G. Sohn, V.A. Springer, R.K. Stucky, W.R. Taylor, J.A.H. Van Couvering, D.J. Ward, S.H. Weitzman, P.J. Whybrow, and G.R. Zug. Participants in our various field parties were J.R. Matzko, T.H. Kiilsgaard, Farah Warsama, Mohammed Mellah, and Mohammed Ali. Wann Langston, Jr., Mark V.H. Wilson, and Roger C. Wood contributed stratigraphic and paleoecologic data concerning crocodilians, fishes, and turtles, respectively. Their detailed observations appear in succeeding chapters.

\section{STRATIGRAPHY}

The vertebrate fossils were collected at 21 localities in the Jabal Umm Himar area (fig. A2). Fossil bone fragments lie on slopes below-and within - a 2-3-m-thick fossiliferous mudstone of the Umm Himar Formation, herein named for Jabal Umm Himar. Stratigraphic sections were measured at each fossil locality and 12 of these sections are shown in figure A3. The type section for the Umm Himar Formation is at locality 3 (figs. A2 and A3). Tentative corre- lations between sedimentary units are shown on the diagram, figure A3. A composite columnar section, figure A4, shows the subdivision of the formation and characteristic thicknesses of its members. North of the Jabal Umm Himar area, parts of the Umm Himar Formation are exposed discontinuously over about $7,500 \mathrm{~km}^{2}$ around the Harrat Hadan plateau (Brown and others, 1963; Gonzalez, 1973; Baghdadi, 1977).

The Umm Himar Formation consists of three members: a basal ferruginous mudstone, a middle fossiliferous interbedded mudstone and shale, and an upper dolomitic limestone. The formation is flat lying and about $22 \mathrm{~m}$ thick. It is underlain by Precambrian rocks consisting of highly deformed metavolcanic greenstones and quartz monzonite (Gonzalez, 1973). In a few places, thin remnants of a quartzitic sandstone of the Khurma Formation (Brown and others, 1963) lie between the Umm Himar Formation and the Precambrian basement rocks.

The top of the Umm Himar Formation is a slightly undulating erosional surface of possible Eocene age covered by locally derived erosional debris less than $1 \mathrm{~m}$ thick. In many places this debris is a silicified breccia. Floodbasalt flows of middle Tertiary age overlie the erosion surface and Umm Himar Formation (Gonzalez, 1973).

\section{KHURMA FORMATION}

Erosional remnants of white to tan, fluviatile quartzitic sandstone and quartz-pebble conglomerate, from 2 to $4 \mathrm{~m}$ thick, are exposed at several places in the Jabal Umm Himar area; such a remnant, not mapped on figure $\mathrm{A} 3$, occurs at locality 41 (fig. A4). The conglomerate lies directly on saprolitic quartz monzonite. Conspicuous crossbedding suggests a generally northerly transport direction (Baghanem, 1972). The rocks are commonly friable but locally are well cemented by silica and iron oxide. The conglomerate contains rounded to subrounded pebbles that are as large as $1.2 \mathrm{~cm}$ in diameter and that average $0.6 \mathrm{~cm}$ across (Baghanem, 1972, p. 17). The sandstone appears to have been gently deformed and to lie with slight angular unconformity beneath the Umm Himar Formation. The quartzitic facies contrasts sharply with the overlying mudstone of the Umm Himar Formation. The sandstone is tentatively correlated with the Khurma Formation that Brown and others (1963) mapped on the northeastern side of the Harrat Hadan plateau.

\section{UMM HIMAR FORMATION}

The basal member of the Umm Himar Formation consists of red-brown oolitic iron oxide and mudstone from 2 to $4 \mathrm{~m}$ thick (figs. A3 and A4). In most places the ferruginous mudstone member lies on saprolitic quartz monzonite of 
Precambrian age, but in a few places, it lies unconformably on the Khurma Formation.

The ferruginous mudstone is massive to poorly bedded, its lower part is characterized by oolitic iron oxide and irregular, fist-sized lumps of massive iron oxide, or bog iron. The oolites are from 0.3 to $2 \mathrm{~mm}$ in diameter and have nuclei of broken oolites, detrital grains, and fossil fragments (Baghanem, 1972). A bog iron specimen (no. 71242) from locality 3 contains about 65.5 percent total iron as $\mathrm{Fe}_{2} \mathrm{O}_{3}$ and FeO. A vertical channel sample (no. 71244) through $50 \mathrm{~cm}$ of oolitic iron oxide contains about 61 percent total iron as $\mathrm{Fe}_{2} \mathrm{O}_{3}$ and $\mathrm{FeO}$, whereas a vertical channel sample (no. 71243) through $1 \mathrm{~m}$ contains about 45 percent total iron as $\mathrm{Fe}_{2} \mathrm{O}_{3}$ and $\mathrm{FeO}$ (table $\mathrm{A} 1$ ). Interstitial quartz, calcite, chlorite, and goethite fill the space between the goethitic oolites (Baghanem, 1972, p. 21). The upper part of the member is ferruginous mudstone containing abundant root casts, as much as $3 \mathrm{~cm}$ in diameter, filled with iron-oxide oolites.

The middle member of the Umm Himar Formation is greenish-gray mudstone and tan shale from 5 to $10 \mathrm{~m}$ thick. The lower half is massive, thick-bedded mudstone, containing detritus, abundant montmorillonite, illite, and subordinate gypsum (Baghanem, 1972, p. 24). Fossil bones are locally abundant in the lower 2-3 m. Most of the bones are disoriented fragments, but a few are articulated.

Carbonate fluorapatite and montmorillonite, according to $\mathrm{x}$-ray diffraction analyses, make up one or more conspicuously white beds, from 3 to $10 \mathrm{~cm}$ thick, in the lower half of the member. The $\mathrm{P}_{2} \mathrm{O}_{5}$ content of one bed is 5.96 percent (chemical analysis by DGMR-USGS Chemical Laboratory, Jiddah). Detrital grains, largely quartz, are sparse. Dispersed oolites, about $1 \mathrm{~mm}$ in diameter, have well developed concentric structure and make up to 20 percent of the sample. They consist largely of montmorillonite and carbonate fluorapatite. The upper part of the middle member and the shaly (lower) part of the upper member, in total a dolomitic shale, contain 1.37 percent $\mathrm{P}_{2} \mathrm{O}_{5}$ (vertical channel sample through $7 \mathrm{~m}$, no. 116218, table A2), which suggests that the entire shale part of the section is slightly phosphatic.

The upper half of the middle member consists largely of interbedded siltstone and shale. Bedding becomes well developed to laminated near the top where the shale is commonly highly fissile.

The upper member of the Umm Himar Formation consists of gray, fine-grained dolomitic limestone that weathers yellowish tan; the rock is mostly well indurated but locally is chalky and white. The top is a greatly undulating erosion surface. The preserved thickness of the member is commonly about $6 \mathrm{~m}$, and the maximum thickness is about 11 $\mathrm{m}$. Bedding ranges from thick bedded to laminar. At most places the lower contact with the shale is abrupt, but in some places the lower few meters consist of impure to silty limestone, or of interbedded limestone and shale. Fossil invertebrates and shell debris are present locally. At least one bed of gastropod coquina, from 10 to $20 \mathrm{~cm}$ thick, lies near the upper part of the stratigraphic section. Baghanem (1972, p. 28) reports well-preserved pelecypods and gastropods, as well as scattered quartz grains, carbonate oolites, and cross laminae. The composition of the carbonate rock is highly variable (table A2, fig. A5) and all samples but one are highly siliceous.

Small sills of basalt intrude the mudstone and shale (middle) member and the dolomitic limestone (upper) member at two localities (localities 3 and 34, fig. A3). The basalt is related to the Oligocene and Miocene Harrat Hadan Basalt. The intrusive basalt locally deforms the bedding of the Umm Himar Formation. This deformation and associated contact metamorphism are intense in places outside the Jabal Umm Himar area of figure A2 where larger sills and plugs of basalt intrude the formation. The intrusion causes local silicification and minor iron oxide replacement of the carbonate rock. One irregular pod of replacement iron oxide, $3 \mathrm{~m}$ long and $2 \mathrm{~m}$ wide, at locality 3 , contains about 63 percent total iron as $\mathrm{Fe}_{2} \mathrm{O}_{3}(71252$, table $\mathrm{A} 1)$. The $\mathrm{Fe}_{2} \mathrm{O}_{3}$ content of the carbonate rock is from 1.5 to 4.1 percent (table A2). The replacement iron contains 1.37 percent $\mathrm{FeO}$, which is proportionately 1.5 to 19 times more abundant than the FeO content of the oolitic iron (table A1). The replacement iron was probably hydrothermally reworked from the sedimentary iron in the section during the emplacement of the intrusive basalt.

\section{CHERT}

A siliceous breccia commonly forms a resistant, nonconformable top on the dolomitic limestone member of the Umm Himar Formation (fig. A3). This cap rock of silicified chert has protected and preserved the Umm Himar Formation. The white cherty breccia weathers dark brown and is commonly from 0.5 to $1.5 \mathrm{~m}$ thick. It consists of silicified, angular fragments, from 0.5 to $3 \mathrm{~cm}$ across, of former carbonate including locally abundant shell debris, as well as other detritus. The siliceous breccia is probably silicified colluvium developed on a low-relief erosional surface cut on the dolomitic limestone of the Umm Himar. Remnants of iron oxide overlie the siliceous breccia in many places, especially where nearby outcrops of basalt have protected the iron oxide from erosion. Silicification extends downward into the dolomitic limestone of the Umm Himar; the gastropod coquina bed is especially well silicified. Baghanem (1972) describes two beds containing abundant gastropods and pelecypods that are replaced by silica near the top of the dolomitic limestone member. Brown and others (1963) mention a "silicified coquina of 'Melanoides'like freshwater snails." It is unlikely that the chert is sedimentary silica related to the deposition of the Umm Himar Formation. It is more probable that the silica is a product of 


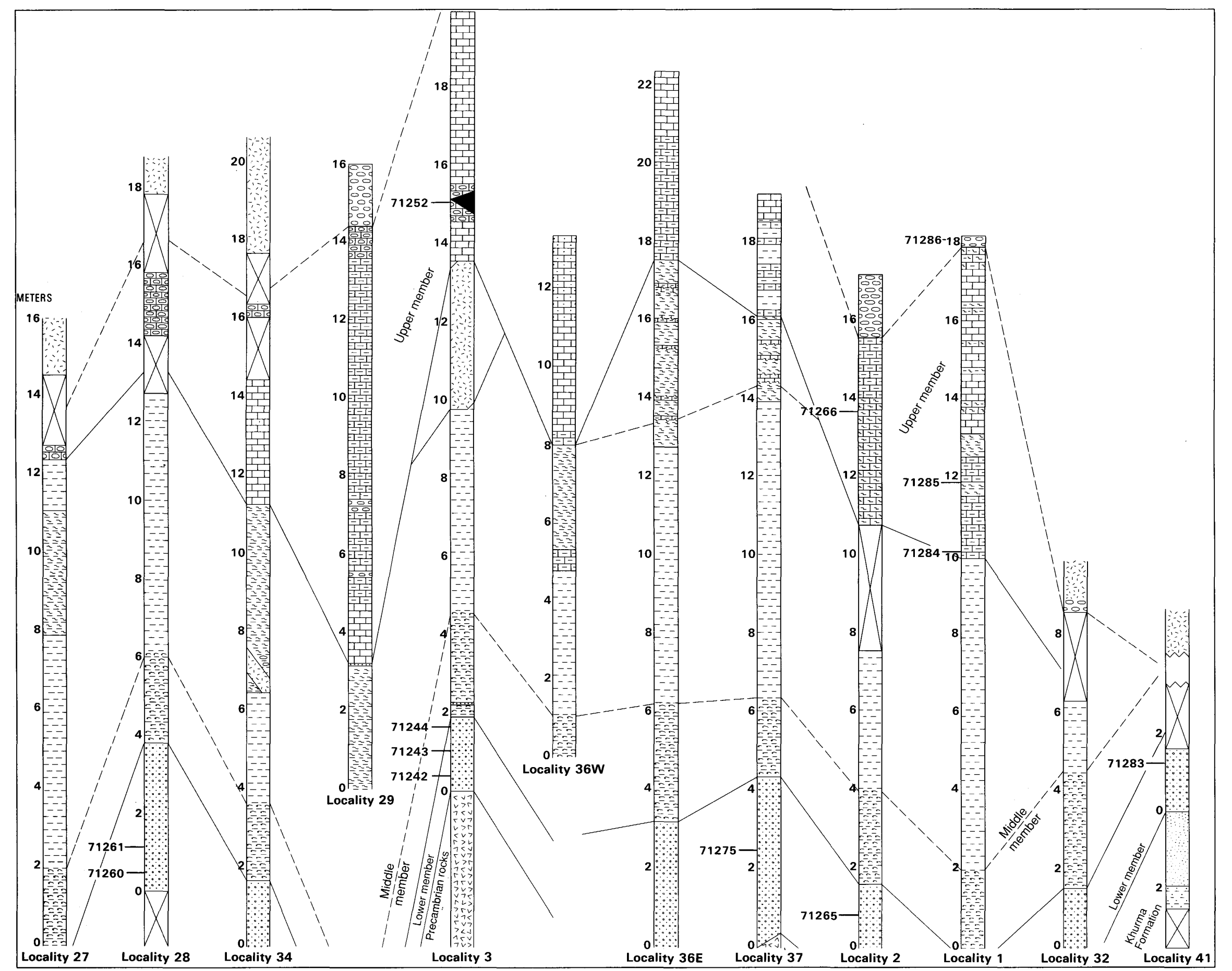


soil processes and laterization following deposition of the Umm Himar Formation.

\section{LATERITE}

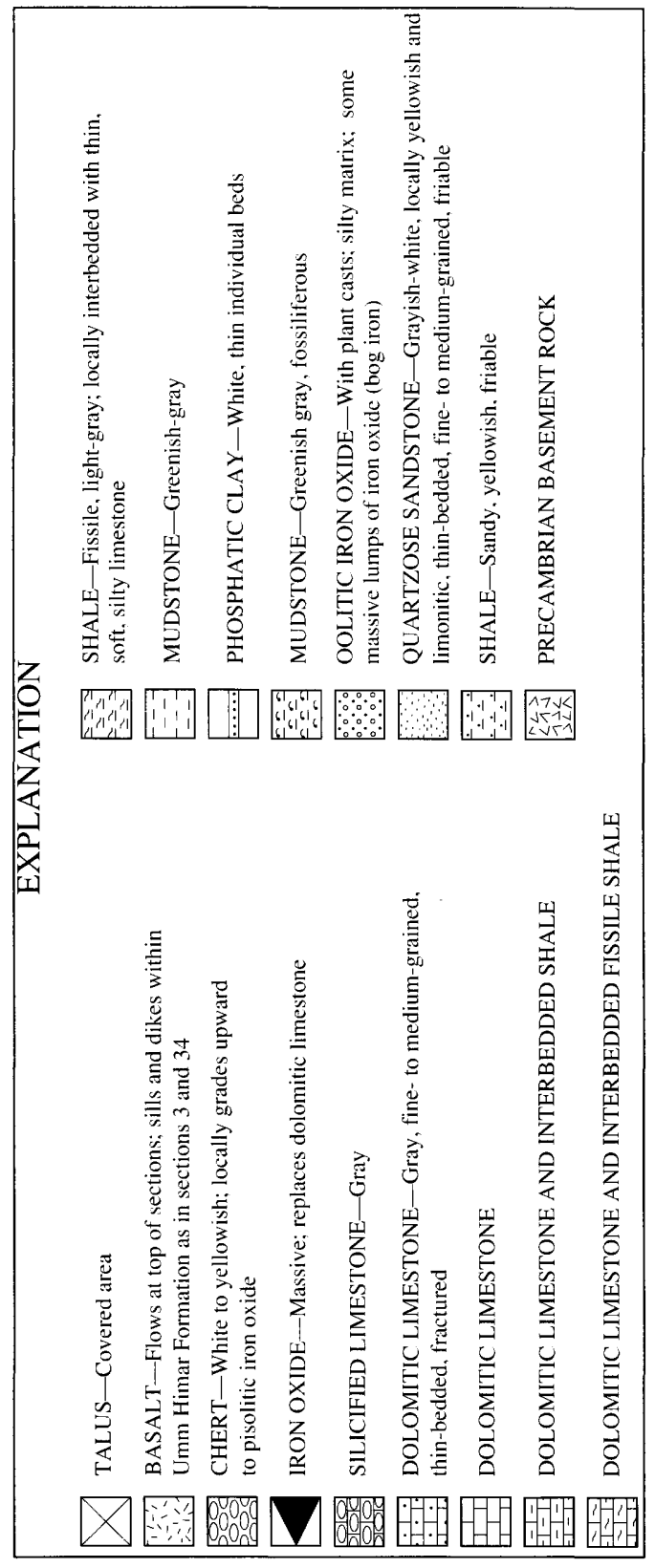

A pisolitic iron-oxide layer, in places several meters thick, lies above a jaspery substratum. This layer is always adjacent to, and overlain by, basalt, in such a way that abundant basalt talus obscures the stratigraphic relations. In places it is inferred to overlie the dolomitic limestone member of the Umm Himar Formation and hence probably lies on the silicified upper part of the formation. At Javbal Saq, $10 \mathrm{~km}$ west of the northwestern corner of the geologic map (fig. A2), a pisolitic iron-oxide layer of laterite (Martin, 1969 , p. 11), about $5 \mathrm{~m}$ thick, lies on sandstone and quartzpebble conglomerate (Khurma Formation?) and is overlain by Tertiary basalt. The average composition of five samples from the Jabal Saq locality (Martin, 1969, p. 8) is given in table A2. Baghanem (1972, p. 36) refers to similar ironoxide layers as "reworked ferric oxide deposits," some about $2 \mathrm{~m}$ thick. They rest on Precambrian rocks or on sandstone and are overlain by Tertiary basalt. A calcic phase in the "reworked deposits" (Baghanem, 1972, p. 37) is probably a carbonate cement deposited in the laterite by carbonate waters associated with the basalt eruptions.

The pisolitic iron-oxide layers are lateritic deposits formed prior to the deposition of the Tertiary basalt as described in the As Sarat area, $350 \mathrm{~km}$ south of Harrat Hadan (Overstreet and others, 1977). In the As Sarat area, the laterite formed during Eocene and early Oligocene time and was covered by upper Oligocene to lower Miocene basalt. A thick saprolite underlies the lateritic and silicic paleosoil zones in both the As Sarat and the Harrat Hadan areas.

\section{HARRAT HADAN BASALT}

Alkalic olivine basalt underlies the Harrat Hadan plateau, which rises nearly $200 \mathrm{~m}$ above the surrounding plain. Numerous buttes are erosional outliers of basalt flows whereas other buttes and conical hills are necks of basalt feeders. The outliers of basalt rest upon the Umm Himar Formation on all sides of the basalt plateau. The steep basalt scarps of the plateau and butte landforms are perpetuated by the underlying, less resistant Umm Himar beds. However, the basalt itself is highly saprolitic beneath its own erosionally resistant outcrop and basalt talus, and this soft, deeply weathered basalt also, in part, accounts for the steep basalt scarps.

The Harrat Hadan Basalt has been dated (fig. A6) by whole-rock K-Ar method at $27.8 \pm 1.4$ and $26.6 \pm 1.3 \mathrm{Ma}$ (lower basalt, olivine tholeiite; Arno and others, 1980); 17.7 $\pm 0.9,16.0 \pm 0.8$, and $15.2 \pm 3.0 \mathrm{Ma}$ (upper basalt, basanite; Arno and others, 1980); and $16.6 \pm 1.5$ and $16.2 \pm 1.8 \mathrm{Ma}$ 


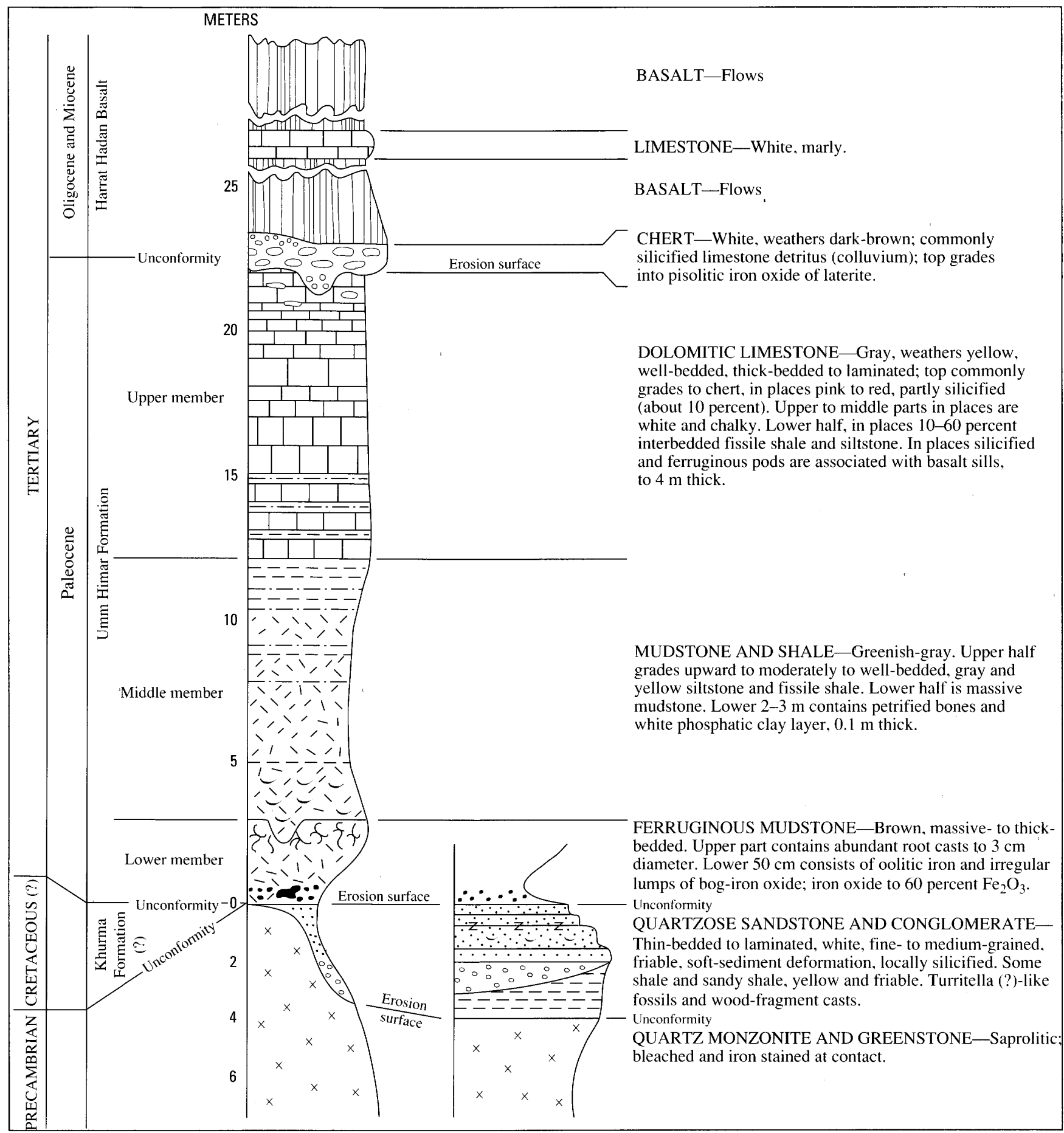

Figure A4. Composite stratigraphic columnar section of the Umm Himar Formation and overlying and underlying rocks in the Jabal Umm Himar area.

(Brown and others, 1989). A "hornblende phonolite" at Jabal 'In, $18 \mathrm{~km}$ west of the northwest corner of figure A2, has been dated at 22.2 $\pm 3.5 \mathrm{Ma}$ (Brown and others, 1989) and is probably a late fractionation product of the parent magma of the Harrat Hadan Basalt.
Basalt from the Harrat As Sarat, which is a high basalt plateau geomorphically similar to Harrat Hadan, has been dated $30.3 \pm 0.5$ and $25.3 \pm 0.5 \mathrm{Ma}$. The Harrat As Sarat contains a late fractionated trachyte dated at $22.3 \pm 0.2 \mathrm{Ma}$ (Brown and others, 1989; Coleman and others, 1975). 
Table A1. Chemical analyses for $\mathrm{Fe}_{2} \mathrm{O}_{3}$ and $\mathrm{FeO}$ and semiquantitative spectrographic analyses for other elements in iron-oxide materials from the Jabal Umm Himar area. See figures A2 and A3 for sample localities.

[Iron analyses by Masoud Shah, H. Karam, and M. Calcalttawy, DGMR-USGS Chemistry Laboratory, Jiddah, May 23, 1977. 0.0 indicates element looked for but not found; other elements also looked for but not found are $\mathrm{Ag}, \mathrm{As}, \mathrm{Au}, \mathrm{Bi}, \mathrm{Cd}, \mathrm{Mo}, \mathrm{Nb}, \mathrm{Pb}, \mathrm{Sb}, \mathrm{Sn}$, and W. All samples are grab samples except as noted]

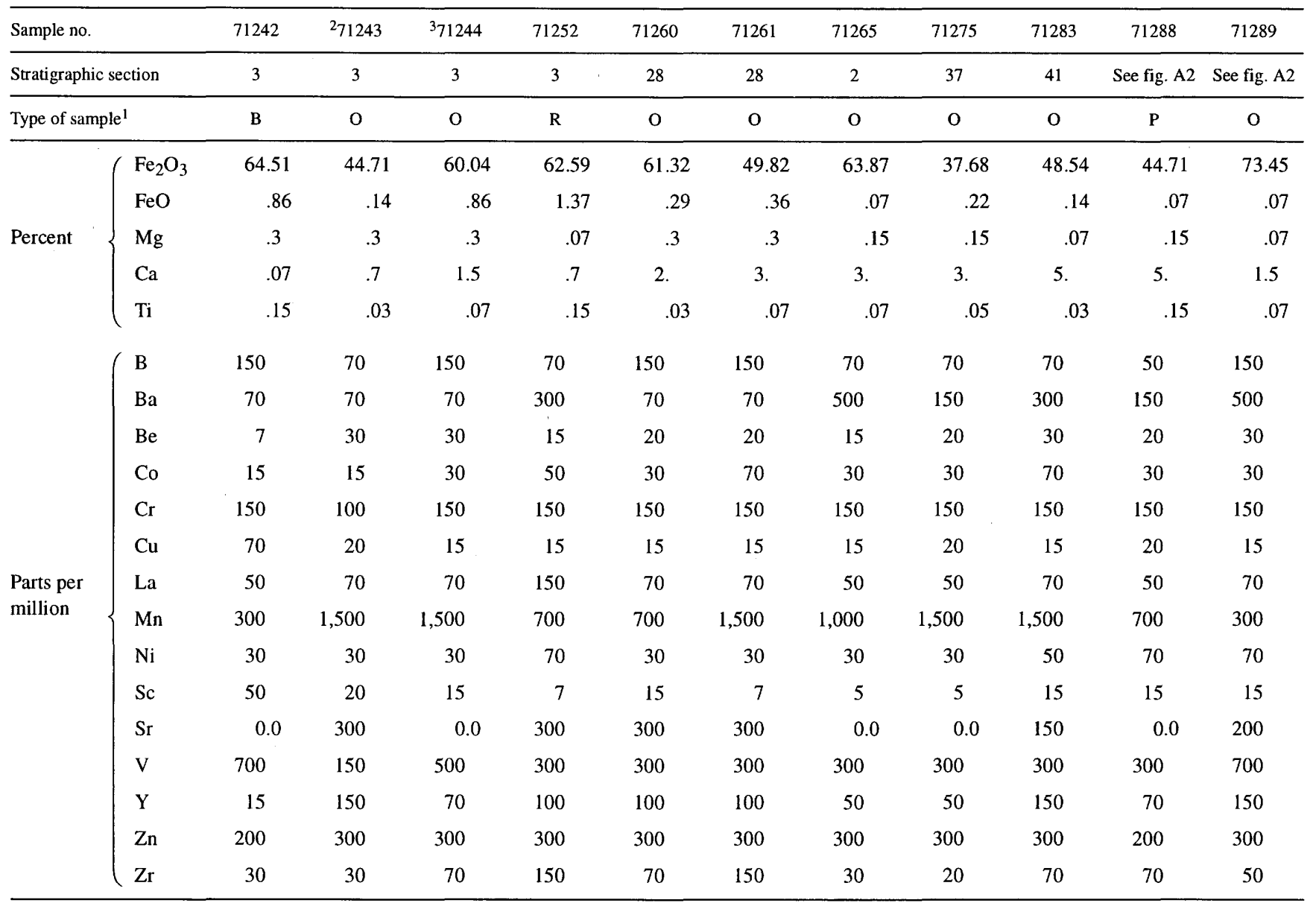

\footnotetext{
${ }^{1} \mathrm{O}$, oolitic iron oxide-sedimentary origin in ferruginous mudstone (lower) member of the Umm Himar Formation.

$\mathrm{B}$, bog iron oxide-massive lumps in ferruginous mudstone (lower) member of the Umm Himar Formation.

$\mathrm{R}$, iron oxide in massive pods replacing dolomitic limestone (upper) member of the Umm Himar Formation.

$\mathrm{P}$, pisolitic iron oxide in laterite overlying the Umm Himar Formation.

${ }^{2}$ Channel sample through $1 \mathrm{~m}$, lower part of ferruginous mudstone (lower) member of the Umm Himar Formation.

${ }^{3}$ Channel sample through $0.5 \mathrm{~m}$, lower part of ferruginous mudstone (lower) member of the Umm Himar Formation.
}

The lower part of the Harrat Hadan Basalt and the whole of the Harrat As Sarat basalt appear to be of similar age between about 30 and $22 \mathrm{Ma}$, whereas the upper part of the Harrat Hadan Basalt above about $20 \mathrm{~m}$ of intercalated limestone appears to range between about 18 and $15 \mathrm{Ma}$. The intercalated uppermost lower Miocene limestone is chemically very different from the dolomite and dolomitic limestone of the Paleocene Umm Himar Formation (fig. A5). We interpret the upper basalt at Harrat Hadan as resting disconformably on the lower basalt.

\section{FAUNA}

The Paleocene vertebrates from the 21 localities have been named the Umm Himar local fauna (Madden and others, 1979). These vertebrates include sand sharks (Odontaspis substriata); nurse sharks (Ginglymostoma maghrebianum, G. sokotoense); early torpedos (Eotorpedo hilgendorfi); eagle rays (Myliobatis dixoni); three species of pycnodont fish (Pycodus spp.); a large amiid (Amiidae gen. et sp. indet.), the first Tertiary member of this family from 
Table A2. Partial chemical analyses, in percent, for major elements of samples from the dolomitic limestone member of the Umm Himar Formation, Jabal Umm Himar area. The average of five samples of pisolitic laterite from nearby Jabal Saq is also given.

[Samples 116216-116221 analyzed by I. Baraja, Masoud Shah, Aziz Khan, and H. Karam, DGMR-USGS Chemistry Laboratory, Jiddah, February 26, 1978; symbol (-) indicates no determination]

\begin{tabular}{|c|c|c|c|c|c|c|c|}
\hline \multirow{4}{*}{$\begin{array}{l}\text { Plot number (fig. A5) } \\
\text { Sample no. } \\
\text { Type of sample }\end{array}$} & \multicolumn{6}{|c|}{ Dolomitic limestone member ${ }^{1}$} & \multirow{2}{*}{$\frac{\text { Laterite }^{2}}{-}$} \\
\hline & 34 & 43 & 52 & ${ }^{6} 1$ & 75 & 848 & \\
\hline & 116221 & 116219 & 116217 & 116218 & 116216 & - & $42121-42125$ \\
\hline & Dolomite & Dolomite & Limestone & $\begin{array}{c}\text { Siliceous } \\
\text { dolomitic shale }\end{array}$ & $\begin{array}{l}\text { Dolomitic } \\
\text { limestone }\end{array}$ & $\begin{array}{l}\text { Siliceous } \\
\text { dolomite }\end{array}$ & $\begin{array}{l}\text { Pisolitic } \\
\text { ironstone }\end{array}$ \\
\hline $\mathrm{SiO}_{2}$ & 15.50 & 20.50 & .90 & 39.50 & 12.40 & 39.20 & 23.8 \\
\hline $\mathrm{Al}_{2} \mathrm{O}_{3}$ & .76 & 4.36 & .40 & 9.90 & .94 & - & .75 \\
\hline $\mathrm{Fe}_{2} \mathrm{O}_{3}$ & 1.59 & 2.55 & 4.14 & 9.52 & 3.19 & - & 43.1 \\
\hline $\mathrm{CaO}$ & 27.29 & 24.73 & 50.60 & 12.54 & 32.16 & 18.20 & 2.9 \\
\hline $\mathrm{MgO}$ & 16.75 & 13.90 & 3.27 & 7.67 & 12.84 & 12.7 & 0.4 \\
\hline $\mathrm{P}_{2} \mathrm{O}_{5}$ & .01 & .17 & .04 & 1.37 & .02 & 一 & - \\
\hline $\mathrm{CO}_{2}$ & 37.60 & 32.80 & 39.88 & 14.93 & 37.41 & - & - \\
\hline Ignition loss & - & - & - & - & - & - & 12.6 \\
\hline
\end{tabular}

\footnotetext{
${ }^{1}$ Samples collected near locality 3 (fig. A2) by L.F. Rooney and D.G. Hadley.

2 Data from Martin, 1969, p. 8. Average of five analyses of five representative grab samples from Jabal Saq, $10 \mathrm{~km}$ west of the northwest corner of figure A2; analyses were made in DGMR-USGS laboratory, Jiddah, 1968.

${ }^{3}$ Chip sample through $5.5 \mathrm{~m}$ of upper part of member (section no. 3) including silicified top.

${ }^{4}$ Chip sample through $4 \mathrm{~m}$ of middle and upper part of member (section no. 3).

${ }^{5}$ Chip sample through $1.2 \mathrm{~m}$ of lower part of member (section no. 3 ).

${ }^{6} \mathrm{Chip}$ sample through $7 \mathrm{~m}$ of lower part of member and shale part of underlying mudstone and shale member (section no. 3 ).

${ }^{7} \mathrm{Grab}$ sample, representative limestone (from near station no. 44, fig. A2).

${ }^{8}$ Data from Baghdadi, 1977, p. 11.
}

the African continental plate; catfishes (Siluriformes); perch (Parapercichthys arabis); a large lungfish (Ceratodus humei); large side-necked turtles (Pelomedusidae gen. et sp. indet.); and medium to large dyrosaurid crocodilians ( $R h a b$ dognathus spp., Hyposaurus nopscai, and Phosphatosaurus sp. (table A3). The most notable feature of this fauna is the association of taxa that originated during the Mesozoic but survived into the early Tertiary: Amiidae, Pycnodontiformes, Ceratodus, Pelomedusidae, and Dyrosauridae. This association is characteristic of the earliest Tertiary (Paleocene to middle Eocene) faunas of Africa (Swinton, 1930; White, 1934; Arambourg, 1952; Arambourg and Joleaud, 1943; Priem, 1897). The Umm Himar local fauna has affinities with the Paleocene faunas of Africa because Arabia was a contiguous part of that continent until the early Miocene (Brown, 1970); since then, as a result of the opening of the Red Sea and other plate movements, Arabia has been attached to Eurasia.

Sharks are represented by Odontaspis substriata, Ginglymostoma maghrebianum, and G. sokotoense. The genera Odontaspis and Ginglymostoma first appeared in the geologic record in rocks of Cretaceous age in Europe, Africa, and Asia, and both occupy nearshore or estuarine habitats in coastal waters (Bigelow and Schroeder, 1948). $O$. substriata is the most common shark at Jabal Umm
Himar, and apparently also at most other African localities during the Paleocene (Arambourg, 1952). The rarest shark is G. maghrebianum, which is represented by only one tooth, from locality 37. Another Ginglymostoma, G. sokotoense, is sympatric with G. maghrebianum at that locality and is known also from locality $36 \mathrm{~W}$.

Torpedos and eagle rays are represented by Eotorpedo hilgendorfi and Myliobatis dixoni, respectively. Remains of eagle rays were collected from 10 of the 21 localities, whereas those of torpedos were collected from only 3 localities. Eotorpedo hilgendorfi is, however, the most common species of torpedo known from the earliest Tertiary of Africa (White, 1934; Arambourg, 1952; Cappetta, 1972; Jaekel, 1904).

The extinct pycnodont fishes belong to the holostean order Pycnodontiformes and are represented by one jaw fragment from locality 1 collected in 1974 by Schmidt, as well as by teeth from seven other localities (table 3; Madden, 1983). Pycnodonts were widely distributed during the Mesozoic, for they are known from Europe, Asia, Madagascar, Africa, and North and South America. However, only in Europe and Africa were these holosteans hitherto known to have survived into the Tertiary; they are known from the Eocene of Europe and from the lower Paleocene to middle Eocene (Danian to Lutetian) of West Africa. The only genus 


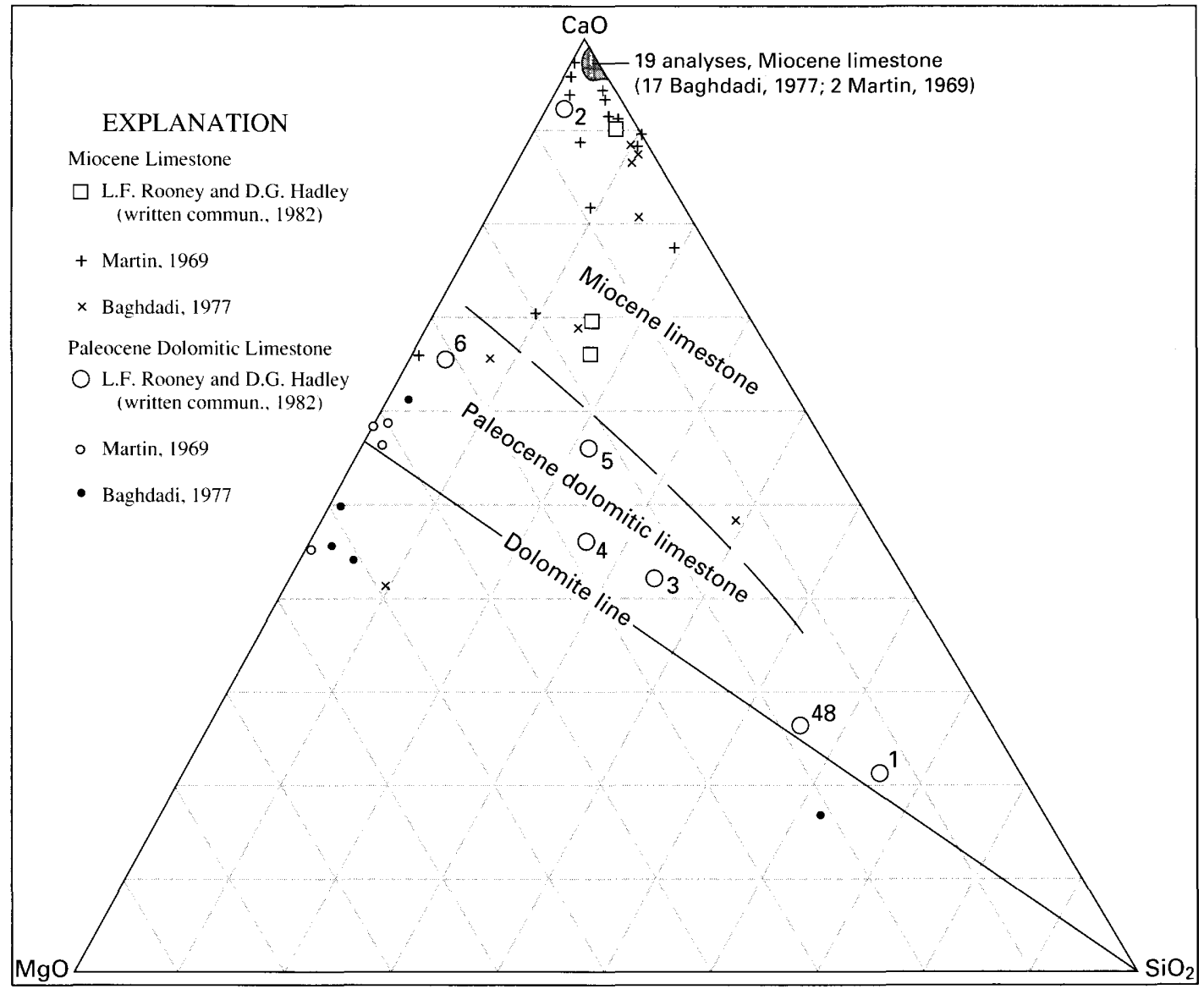

Figure A5. Tertiary diagram $\left(\mathrm{CaO}-\mathrm{MgO}-\mathrm{SiO}_{2}\right)$ showing composition of dolomitic limestone from the upper member of the Umm Himar Formation, Jabal Umm Himar area (see table A2), as compared to limestone in the overlying Miocene flood basalts.

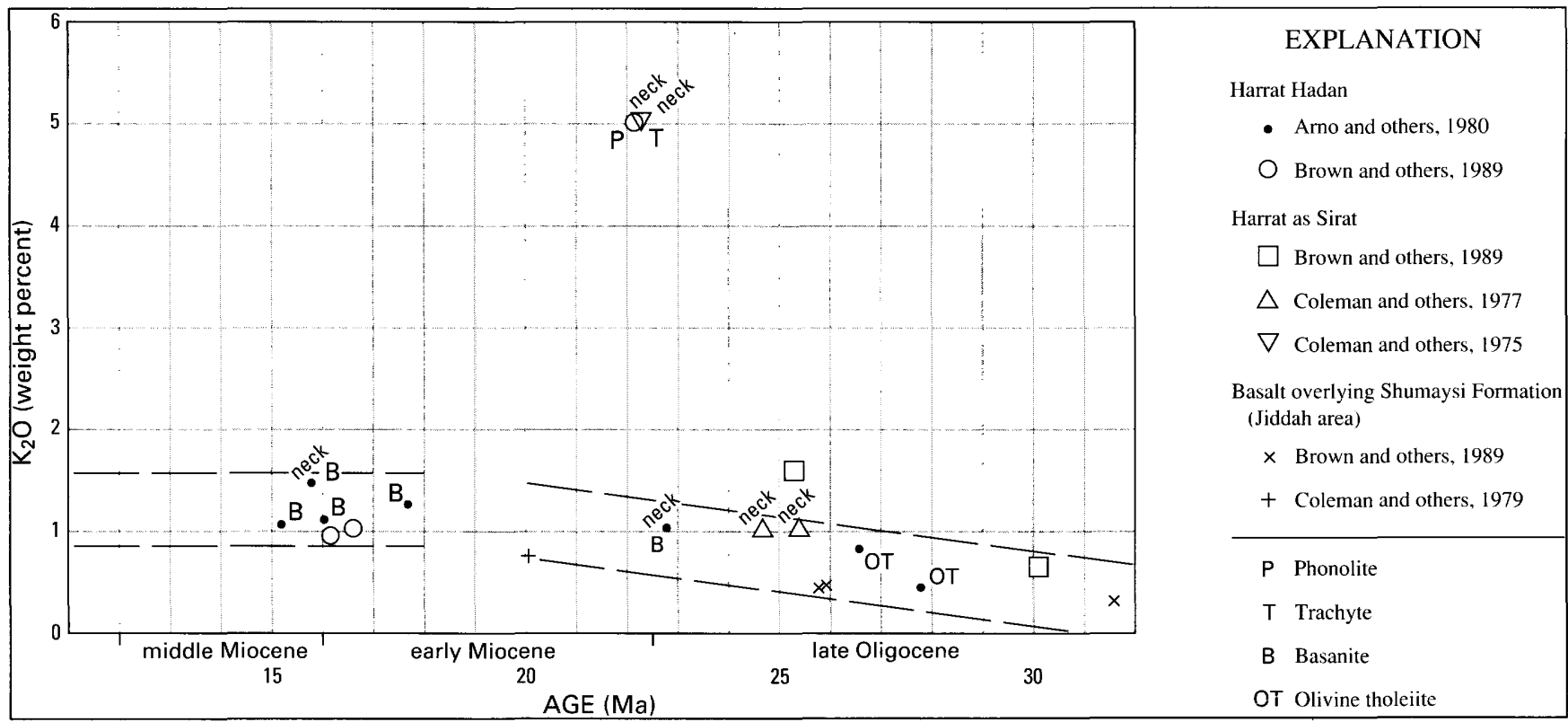

Figure A6. Diagram showing isotopic age plotted against $\mathrm{K}_{2} \mathrm{O}$ content for basaltic rocks from Harrat Hadan and from correlative basaltic rocks from other areas. 
Table A3. List of vertebrate fossils from the localities at Jabal Umm Himar.

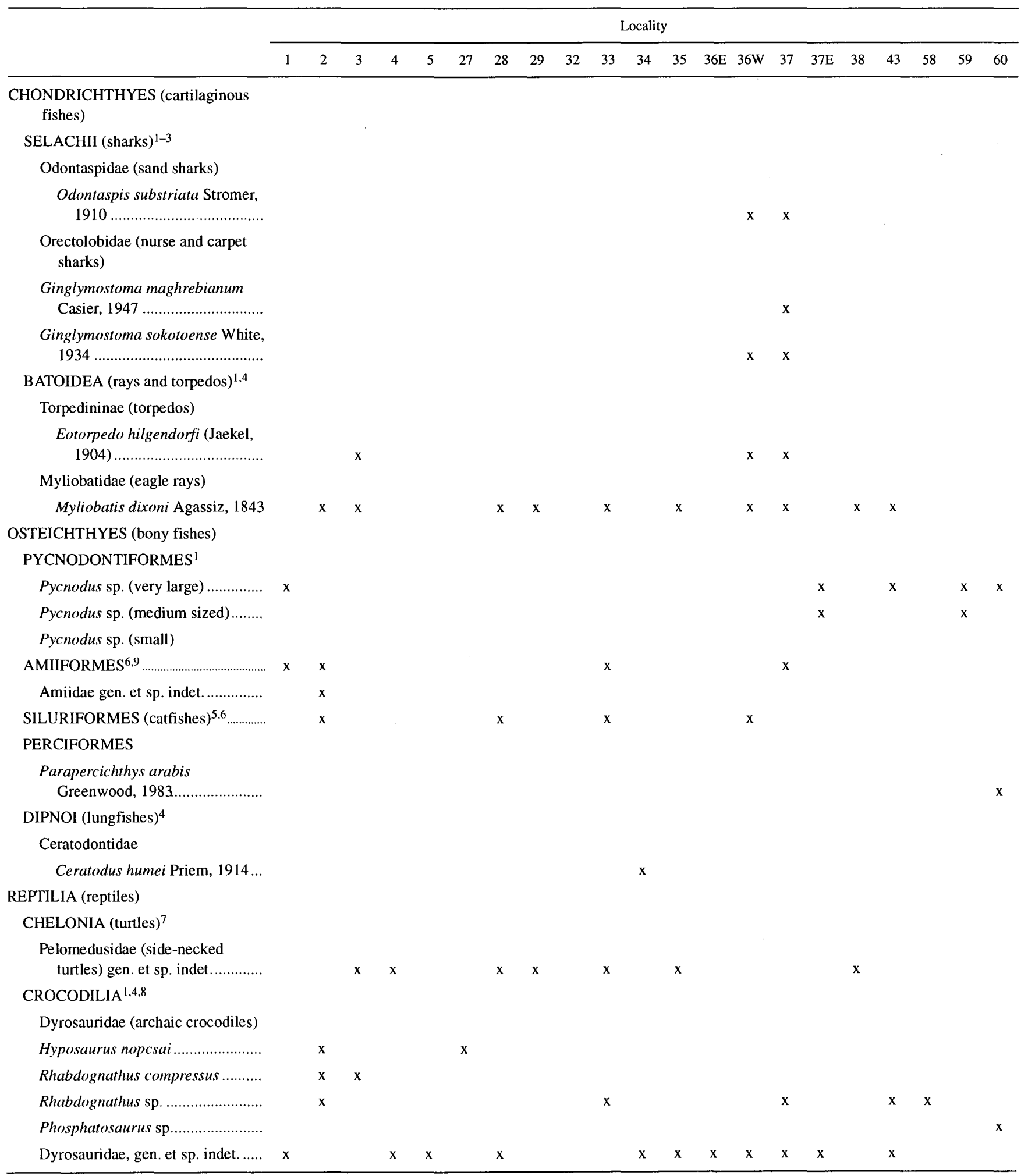

${ }^{1}$ Identified by C.T. Madden.

${ }^{2}$ Identified by R.W. Purdy.

${ }^{6}$ Identified by R.K. Stucky.

${ }^{3}$ Identified by D.J. Ward.

${ }^{7}$ Identified by R.C. Wood.

${ }^{8}$ Identified by Wann Langston, Jr.

${ }^{4}$ Identified by F.C. Whitmore, Jr. $\quad{ }^{9}$ Identified by M.V.H. Wilson.

${ }^{5}$ Identified by W.R. Taylor. 
known from the lower Tertiary is Pycnodus; the fossils from Jabal Umm Himar are assigned to that genus. On the basis of tooth size we estimate that three species were present. The upper jaw bone from locality 1 represents the largest pycnodont known from Africa.

Amiids are represented by a single vertebra from locality 2 , interpreted as an anterior caudal centrum of a large species, probably not congeneric with any amiid of Tertiary age (Wilson, Chap. C, this volume). Until now, only polypterids and lungfishes were known from Paleocene freshwater deposits in Africa (Van Couvering, 1977). Fossil Amia species are known from Tertiary freshwater deposits of Eurasia and from Cretaceous and Tertiary freshwater deposits of North America (Boreske, 1974). The occurrence of a Paleocene amiid in an assemblage that has African affinities suggests either incomplete isolation of the African-Arabian freshwater fauna or a long prior history for amiids on the African plate.

Catfish spines and vertebrae were recovered from 4 of the 21 localities (localities 2, 28, 33, 36W). These remains were identified by W.R. Taylor of the U.S. National Museum of Natural History and R.K. Stucky, then of the University of Colorado Museum. Stucky (written commun., 1979) has reported that three types of catfishes are represented. Elsewhere in the African plate, catfishes are first known from the lower Paleocene (Montian) of the Congo (now Zaire; Casier, 1960) and also from the upper Paleocene of Nigeria (White, 1926, 1934; Cappetta, 1972). These are the earliest records for the order in the Old World; catfish have been reported from the Cretaceous of Bolivia (Wenz, 1969) and of Patagonia (Cione and Laffite, 1980) and from the Cretaceous of South Dakota (Frizzell, 1965).

Lungfish are represented by a single tooth of a very large Ceratodus from locality 34 . This specimen is identified as Ceratodus humei because of its few ridges and large size. $C$. hume $i$ is endemic to the African plate. It first appeared in the Early Cretaceous and last appeared in the Paleocene (Whitmore, Chap. D, this volume). This is one of few species of Ceratodus that survived into the Tertiary. $C$. hume $i$ was widely distributed; it is known from both North and West Africa.

Turtle remains are known from 15 of the 21 localities, but only those from localities $3,4,26,29,33,35$, and 38 are identifiable. These remains represent what is probably a single species of pelomedusid (side-necked) turtles (Wood, Chap. E, this volume). The Jabal Umm Himar turtle was very large, its shell roughly comparable in size with that of the largest living side-necked species, Podocnemis expansa, from the Amazon and Orinoco basins of South America; a badly fragmented shell from locality 35 measured some 90 $\mathrm{cm}$ in length. Modern pelomedusids are confined to South America, sub-Saharan Africa, and Madagascar. However, this group was much more widely distributed during the earliest Tertiary (Wood, 1984): Paleocene side-neckers are known from Europe, the Pako-Indian subcontinent, North
Africa, sub-Saharan Africa, and South America. The Arabian species partly bridges the geographic hiatus between the Paleocene pelomedusids known from North Africa and those from the Pako-Indian subcontinent. This turtle was probably essentially aquatic, judging from its flattened shells.

Crocodilian remains vary in abundance at 15 localities. All are recognizable as members of the primitive Suborder Mesosuchia, Family Dyrosauridae. Three genera are represented: Rhabdognathus, Hyposaurus, and Phosphatosaurus. The Dyrosauridae range from the Late Cretaceous (late Maastrichtian) to late Eocene and have been reported from North and West Africa, North and South America, and Asia (Pakistan and Burma). The Dyrosauridae are thus demonstrated to have had a southern Tethyan distribution (Langston, Chap. F, this volume). The material from Jabal Umm Himar includes three partly articulated but incomplete skeletons of the dyrosaur Rhabdognathus sp. This material permits the first attempt at skeletal reconstruction of a longirostrine dyrosaur. The Dyrosauridae of the Umm Himar Formation strongly resemble those of the Dange Formation, upper Paleocene, of Sokoto Province, Nigeria.

During excavations at locality 37 , large and small smooth rounded pebbles and cobbles of quartzite were found near the crocodile skeleton. Quartzite rocks are not indigenous to the fossil bed, and these were probably transported as gastroliths, or gizzard stones, by the reptile.

\section{AGE}

The Jabal Umm Himar vertebrate local fauna is assigned a Paleocene age on the basis of stratigraphic ranges of the lungfish Ceratodus humei, the dyrosaurid crocodilians Rhabdognathus compressus and Hyposaurus nopcsai, and catfish (Siluriformes).

With one questionable exception, $C$. hume $i$ has been reported in beds no later than the Paleocene. The two dyrosaur species are known only from the Paleocene of Mali and from the Dange Formation (late Paleocene, Thanetian) of Sokoto Province, Nigeria, whose age has been determined on the basis of Foraminifera (Petters, 1978). Langston (Chap. F, this volume) states that the strong resemblance of the Umm Himar dyrosaurs to those of the Dange Formation suggests a late Paleocene age for the Umm Himar Formation. Ceratodus and the Dyrosauridae are Mesozoic animals that survived into the Paleogene of the Tethyan region.

The catfishes (Siluriformes), on the other hand, are typically Tertiary forms. They are unknown in pre-Tertiary rocks of Europe, Asia, or Africa, but have recently been reported from the Cretaceous of South America.

The stratigraphic range of the fossil sharks is consistent with a Paleocene age for the Umm Himar Formation. 


\section{ENVIRONMENT}

The environment of Jabal Umm Himar in Paleocene time was estuarine or lagoonal; the climate was either tropical or subtropical, but probably seasonally arid in the nearby interior. These reconstructions are based upon the presence of certain vertebrates, their fossilized condition, and the type of sediments in which they were deposited.

All the shark and ray genera identified from Jabal Umm Himar occupy salt-water and brackish-water habitats in modern seas and oceans. The most notable feature of this fauna, from a paleoenvironmental viewpoint, is the presence of nearshore forms. Odontaspis, Ginglymostoma, and Myliobatis occupy coastal habitats, either nearshore or estuarine, and are most abundant in shallow waters (Bigelow and Schroeder, 1948, 1953). Catfish are also found in both fresh and salt water. The presence of Ginglymostoma indicates a tropical or subtropical environment because these sharks inhabit only tropical and subtropical seas and oceans at present. The dyrosaurs were evidently euryhaline forms (Langston, Chap. F, this volume), but like the sharks and rays from Jabal Umm Himar, they are most often found in shallow marine sediments that indicate nearshore and possibly estuarine environments.

The lungfish Ceratodus humei indicates a probable seasonally arid climate, at least for the nearby interior. Most modern lungfish, namely species of African Protopterus and South American Lepidosiren, inhabit shallow ephemeral bodies of fresh water in seasonally arid climates. They survive in such climates by burrowing into bottom mud and aestivating during dry seasons. The single specimen of $C$. humei was probably transported to Jabal Umm Himar from a freshwater habitat in the nearby interior. Modern lungfish inhabit fresh water exclusively. Assuming that the amiid was a freshwater fish that had habits similar to those of Holocene Amia, the single vertebra was probably also washed into the deposit from a large river or shallow lake environment.

Clams from near the top of the Umm Himar Formation were identified by N.F. Sohl and E.G. Kauffman (written commun., 1975) and the late J.H. Hanley (written commun., 1977) as Brachydontes and a Corbicula-like form. The association of these two mollusks is indicative of a brackish-water environment. Deposits of this marginal marine environment are now exposed over an area of some $60 \mathrm{~km}$ by $120 \mathrm{~km}$.

The fossil bed is composed of shallow-water deposits, either lagoonal or estuarine, that are poorly sorted and poorly consolidated. Such deposits indicate a low-energy environment, one having little or only gentle current action. Partly articulated crocodile skeletons at localities 33 and 37 are consistent with this interpretation. Abundant iron oolites and root casts in the bed immediately below the fossil bed suggest a lagoonal marsh in which tides provided the agitation for oolitic growth. The deposition of iron oxide in the Jabal Umm Himar area also suggests a tropical environment. In the Lake Chad region today, which can be used as a modern analog (Lemoalle and Dupont, 1973), iron is transported from a tropical zone of lateritic soil to a saline environment at Lake Chad where iron is deposited as oolites. In Lake Chad the water salinity is a result of an arid climate, but at Jabal Umm Himar the depositional salinity was provided by the proximity of the sea and aridity need not be implied by evidence of the iron oolites. Kaolinite is the characteristic product of tropical weathering. Colloidal and (or) absorbed iron and kaolinite are transported in acid river water. On entering brackish or saline water, the solution becomes basic and the kaolinite is converted to montmorillonite (the common clay in the Umm Himar deposits) and reactive iron is precipitated with silica in the form of oolites.

At Jabal Umm Himar a tropical environment and tropical weathering persisted after the deposition of the Umm Himar Formation. This is indicated by the development of a laterite upon the Umm Himar deposits. The siliceous part of the soil profile is best preserved, but, in places, remnants of the pisolitic iron oxide (upper part of the profile) are preserved and overlain by the Harrat Hadan Basalt, which is as old as late Oligocene.

In the southern Arabian Shield, laterite, overlying a siliceous subsoil and thick saprolite, is well preserved beneath the basalt flows of the As Sarat; the lowest flows are dated about late Oligocene (Coleman and others, 1977). The lower basalt flows themselves are partly lateritized (Overstreet and others, 1977, p. 10) and the equivalent Yemen Volcanics (formerly Trap Series) to the south contain intercalated paleosols (Overstreet and others, 1977, p. 10; Grolier and Overstreet, 1978).

It is interesting to note that the four types of iron oxide deposits in the Jabal Umm Himar area probably have a common initial source of iron that is associated with tropical weathering. This is suggested by similar minor-element abundances for all the iron types (semiquantitative spectrographic analyses, table A1). The pisolitic iron of the laterite was a direct product of tropical weathering of the Umm Himar deposits. The oolitic iron and the bog iron, deposited in the basal part of the Umm Himar Formation, resulted from iron transported from nearby lateritic soils. The replacement iron in the dolomitic limestone member probably was hydrothermally reworked iron from the other three deposits; the hot intrusive basalt of Harrat Hadan Basalt age heated interstitial water in the Umm Himar sediments and, through convection, the hot water transported and deposited iron in the dolomitic limestone. 


\section{OTHER VERTEBRATE FOSSILS FROM THE ARABIAN PENINSULA}

The vertebrate fossils from Jabal Umm Himar represent the first Paleocene vertebrate fauna known from the Arabian Peninsula. Fossil vertebrates found elsewhere in the peninsula range in age from the Devonian to the late Pleistocene.

Leliève (1989) reported the first known occurrence of Devonian vertebrates in Saudi Arabia. Two dermal plates found in the Jawf Formation, northeast of the Arabian Shield, seem to indicate an early Emsian age. One plate was identified as from an arthrodire, Suborder Brachythoraci, and was tentatively referred to the Family Buchanosteidae. The other specimen was indeterminate.

Unidentifiable bones were reported from the Jilh Formation of Triassic age in eastern Saudi Arabia (Powers and others, 1966, p. D36).

F.C. Whitmore, Jr. (written commun., 1976) has identified two vertebrae collected by P.L. Binda (formerly with the Saudi Arabian Directorate General of Mineral Resources and King Abdulaziz University, Jiddah) from the Jurassic Hanifa limestone southeast of Jizan as belonging to an archaic (mesosuchian) crocodile.

Karpoff (1957) reported that fossils collected from the Usfan Formation of Eocene age, near Jiddah, include sharks; he (written commun., 1977) reports that these forms represent galeoids.

Thomas and others (1989) report terrestrial vertebrates of early Oligocene age from the Ashwaq formation at two localities in the southern part of the Dhofar (Sultonate of Oman). Eleven species of mammal are present, representing five orders (Primates, Proboscidea, Embrithopoda, Hyracoidea, and Rodentia).

R. Meyer (written commun., 1975) has identified a fish fauna of modern African or Asian affinities from the lower Miocene Baid Formation in the Ad Darb area, Jizan region (Schmidt and others, 1982). Dunkle (in Brown, 1970) identified a similar fauna from the same formation and region.

Powers and others (1966, p. D97) reported the first fossil vertebrates from eastern Arabia: indeterminate sharks from the Hadrukh Formation of probable early Miocene age and indeterminate vertebrates from the Dam Formation of early Miocene (Burdigalian) age. Later, Tleel (1973) reported fossil mammals from the latter formation, near Dhahran; his report is the first published reference to Tertiary mammals from the Dam Formation. Three vertebratebearing lithostratigraphic units of Miocene age have been formally named in eastern Saudi Arabia. They are, in ascending order of age, the Hadrukh (continental), Dam (marine), and Hofuf (continental) Formations (Whybrow, 1984; Whybrow and others, 1987).

Whybrow and others (1982) described a fauna from the Hadrukh Formation of early Miocene age: rodents, including two new genera in the families Zapodidae and
Cricetidae; antelope; an ochotonid lagomorph; and teeth of sharks and teleosts, possibly reworked from lower beds. Fossil fruit of the tribe Potamogetoneae (pondweeds and ditch grasses) were found. The reports of rodents and plants were the first for the Neogene of Saudi Arabia.

Hamilton and others (1978) recorded two faunas from the Dam Formation: (1) the Jabal Midra Ash-Shamali fauna includes a fish (Lates), turtle, rabbit, cricetodont rodent (cf. Cricetodon atlasi), an indeterminate dipodid rodent, and small and medium-sized species of bovids; (2) the Ad Dabtiyah fauna consists of fish, turtle, crocodile, two new but indeterminate species of dryopithecine apes (see also Andrews and others, 1978), an indeterminate carnivore, indeterminate rodents, a geniohyid hyracoid (cf. Pachyhyrax championi), a shovel-tusked gomphotheriid proboscidean (Platybelodon [possibly Amebelodon filholi, eds.]), two rhinoceroses (Brachypotherium sp. and Dicerorhinus or Aceratherium sp.), two indeterminate species of pigs, a chevrotain (Dorcatherium cf. D. libiensis), an indeterminate giraffe, and an indeterminate boselaphine bovid. A delphinoid cetacean has also been found in the Dam Formation (Whitmore, 1987). Fossil vertebrates from the Dam Formation have also been described by Thomas and others (1982) and by Buffetaut (1984).

Further studies of the Ad Dabtiya local fauna, from the continental equivalents of the Dam Formation, have been led by P.J. Whybrow (1987). These include a report on a new hominoid, Heliopithecus leakyi Andrews and Martin 1987, separate papers on the mastodons, rhinoceroses and ruminants by Gentry (1987), suids (Pickford, 1987) and a cyprinid fish (Greenwood, 1987).

Thomas and others (1978), Sen and Thomas (1979), Thomas (1983), and Morales and others (1987) described a middle Miocene fauna from the Hofuf Formation near Al Jadidah, south of Damman in eastern Saudi Arabia. This fauna includes a hyena (Percrocuta sp.), two rodents, a proboscidean (Gomphotherium angustidens), a rhinoceros (Dicerorhinus cf. D. primaevus), a pig (cf. Lopholistriodon sp.), a giraffe (Palaeotragus sp.), and three species of bovids.

A late Miocene mammalian fauna, including the proboscidean Stegotetrabelodon grandincisivum, occurs at Jabal Barakah on the coast of Abu Dhabi in the United Arab Emirates (Glennie and Evamy, 1968, p. 81-82; Madden and others, 1982; Madden and Whitmore, 1983). Whybrow (1989) named the Baynunah Formation, applying the name to "...surface exposures of fossiliferous late Miocene sediments found in the United Arab Emirates and located east of 52 degrees, zero minutes east and north of 22 degrees, 30 minutes north." Jabal Barakah was designated as the type section.

Miocene vertebrates also occur in southwestern Saudi Arabia. A fish fauna of early Miocene age was found in the Baid Formation at Ad Darb (Madden and Whitmore, 1983) and a mammalian fauna including the anthracothere Mas- 
ritherium occurs in the same formation at nearby Wadi Sabya (Madden and others, 1983).

Brown (oral commun., 1977) reports that some years ago an advanced horse fossil of late Tertiary age was collected at $\mathrm{Al} \mathrm{Hufuf} \mathrm{Oasis.}$

Mammal bones have been found in lake beds of late Pleistocene age in the Rub' Al Khali, the Empty Quarter of the southern Arabian Peninsula. McClure (1978, p. 261) reports Bos primigenius, Bubalus, and Hippopotamus. J.W. Whitney collected bones representing a large bovine, two species of antelope, Equus sp., and a small canid (F.C. Whitmore, Jr., written commun., 1980, 1981).

\section{GEOLOGIC HISTORY}

Vertical movements on the central Arabian arch controlled erosion and sedimentation in central Arabia during the Paleozoic and Mesozoic (Powers and others, 1966, p. D103). During the Middle Cretaceous, southern Arabia was uplifted while northern Arabia continued to subside. The Hail Arch first emerged during the Late Cretaceous along an axis trending north-northwest through the vicinity of Hail (fig. A1). The Aruma Formation, Upper Cretaceous, consisting of sandstone and an upper phosphorite bed, shows distinct facies changes across the arch. By the Paleocene, during further uplift of the arch and contraction of the Tethys Sea, a Mediterranean seaway was separated from the eastern seaway of the Arabian Gulf (Powers and others, 1966, p. D104). Paleocene deposition is represented by the lower part of the Hibr Formation of limestone and phosphorite beds in the Sirhan-Turayf basin of western Saudi Arabia on the west side of the arch (Meissner and Ankary, 1972) and Jordan (Bender, 1975) and by the Umm er Radhuma Formation (Powers and others, 1966) on the east side of the $\operatorname{arch}$ (fig. A1).

The Mediterranean seaway transgressed southward across Egypt, and Upper Cretaceous and Paleocene marine beds were deposited; maximum transgression in Egypt was during the late Paleocene (Landenian) (Said, 1962, p. 144145). Evidence of this marine transgression is not preserved in the Sudan (Whiteman, 1971). Maximum southerly transgression of the seaway reached the vicinity of Jiddah where a marine limestone, the Usfan Formation, was deposited during the late Paleocene(?) (Karpoff, 1957; Brown, 1970). The Usfan Formation consists of, in ascending order, fossiliferous marine limestone, fine-grained sandstone with minor silty sandstone beds, glauconite sandstone (approximately dated at $55 \pm 1.2$ and $42.8 \pm 1.0 \mathrm{Ma}$ by the whole rock $\mathrm{K}-\mathrm{Ar}$ method), and chert (possibly silicified marl) (Brown, 1970). Brown and others (1963) report a phosphatic constituent in the Usfan. The maximum southerly transgression, the Jiddah embayment, extended more than $200 \mathrm{~km}$ east of Jiddah and east of Taif. A coastal area (strand line) existed in the vicinity of Harrat Hadan at the
Jabal Umm Himar fossil locality. The embayment axis may have been in the present location of the Red Sea.

The eastern boundary of the Jiddah embayment was probably along a southern extension of the Hail Arch, and the southern embayment perhaps connected with the Paleocene Sirhan-Tirayf basin to the north. At Jabal Umm Himar, the Umm Himar Formation, initially more than $22 \mathrm{~m}$ thick, was deposited during the Paleocene in a restricted lagoonal-estuarine environment.

In the Harrat Hadan area the Umm Himar Formation is underlain by quartzose sandstone and quartz-pebble conglomerate of the Khurma Formation (Brown and others, 1963). The Khurma Formation is a mature fluviatile deposit of Nubian facies. The continental Khurma Formation may be correlated with some part of the marine sandstone of the Aruma Formation that was deposited in the early SirhanTurayf basin in the northwestern part of Saudi Arabia. In Sudan, the youngest Nubian Sandstone is Upper Cretaceous (Turonian; Whiteman, 1971, p. 50). In Egypt, the Nubian Sandstone underlies Cenomanian deposits (Said, 1962, p. 318).

After deposition of the Umm Himar Formation, the sea receded from the Jiddah embayment. Slight erosion of the upper part of the formation resulted in a gently undulating surface covered by limestone colluvium. This debris was subsequently weathered to a laterite in a semitropical or tropical climate both in Saudi Arabia (Overstreet and others, 1977) and in Sudan (Delany, 1954). Still later, much of the ferriferous part of the lateritic soil was eroded leaving the underlying silicic part of the soil profile. This resistant silicified soil zone, in addition to a low relief that was near sea level, accounts for the preservation of the thin Umm Himar Formation for about 30 million years until it was covered by the Harrat Hadan Basalt.

The complete regression of the Paleocene sea by late early Eocene is well recorded in the Sinai, Gulf of Suez, and northern part of Egypt (Tromp, 1950, p. 386; Said, 1962, p. 145). A significant regional unconformity lies at the base of the middle Eocene in Egypt (Tromp, 1950). Another broad but brief transgression and regression resulted in middle Eocene limestone deposition in Egypt. However, in the Gulf of Suez, a continuous marine section of late Eocene and Oligocene age indicates that some form of narrow seaway persisted at least in the Gulf (Tromp, 1950).

In the Jiddah area, the lower and middle parts of the Shumaysi Formation were freshwater deposits of early Eocene age (Moltzer and Binda, 1981). In contrast, the upper part of the Shumaysi contains sparse layers of silicic ash that should be correlative to the late Oligocene and early Miocene Jizan Group of the southern Red Sea coastal plain (Schmidt and others, 1982). The uppermost part of the Shumaysi consists of siltstone, shale, and limestone containing pelecypods and gastropods of a mixed marine and freshwater environment (Al-Shanti, 1966; Moltzer and 
Binda, 1981), but a marine environment of this age has not been reported from anywhere else in the Red Sea region.

The sedimentary Shumaysi Formation is conformably overlain by a thick section of basalt flows dated by the whole-rock K-Ar method at $25.9 \pm 3.0,32.6 \pm 2.0,25.8 \pm$ 5.0 (Brown and others, 1989), and $20.1 \pm 0.7 \mathrm{Ma}$ (Coleman and others, 1979) and undoubtedly is penecontemporaneous to the extension of the lower part of the Harrat Hadan Basalt (fig. A6). The Jiddah area rocks were subsequently extensionally block faulted in latest early Miocene time during the first-stage seafloor spreading of the Red Sea (Schmidt and others, 1982).

The continental flood basalt of the Harrat Hadan is alkalic and of late Oligocene to early Miocene age. The earliest alkalic flood basalts from around the Red Sea are also of the same age. In Egypt, scattered but widespread thin basalt flows overlie fluvio-marine sediments as young as late Oligocene and are overlain by lower Miocene marine sediments well dated by fossils (Tromp, 1950, p. 390). Basal flows of the Ethiopian basalt series in southeastern Sudan have been dated at $33 \mathrm{Ma}$ by the K-Ar method (Grasty and others, 1963, p. 101) but this date is considered too old by Jones and Rex (1974). The basal basalt overlies laterite and contains interbeds of mudstone with plant fossils, $0.5 \mathrm{~m}$; limestone with crocodile, catfish, and wrasse fossils, $1 \mathrm{~m}$; and dolomite, $0.2 \mathrm{~m}$ (Delany, 1954, p. 16; Whiteman, 1971, p. 103). The Ethiopian basalt series in Ethiopia is dated at 27-23 Ma by Jones and Rex (1974), which corresponds well to the As Sarat and lower part of the Harrat Hadan ages of 30-22 Ma in southern Saudi Arabia, about $250 \mathrm{~km}$ east of the basalts in Sudan and Ethiopia (distance with Red Sea closed). Corresponding flood basalts in Yemen are between 29 and $20 \mathrm{Ma}$ (Civetta and others, 1978). In the Afar of Ethiopia, the early volcanics are dated from latest Oligocene to early Miocene (Mohr, 1975).

The Red Sea escarpment was first significantly uplifted 5-10 million years after the extensive early continental basalt volcanism and after the initiation of the firststage opening of the Red Sea. This rise of the Red Sea escarpment and the resultant elevation of the Harrat Hadan plateau started the present erosion cycle there. The erosionally resistant laterite on the Umm Himar Formation formed a lagging stripped surface adjacent to the receding basalt scarp of the Harrat Hadan plateau. The Harrat Hadan Basalt was deeply weathered to saprolite during the Miocene and Pliocene, and the low erosional resistance of the saprolitic basalt greatly enhanced the stripping process and the development of the plateau landform. Erosion in the Harrat Hadan area was augmented by continued uplift of the Red Sea escarpment during the second-stage opening of the Red Sea after about $5 \mathrm{Ma}$. The combined uplift has elevated the Umm Himar Formation at Harrat Hadan about 1,200 m above its probable correlative, the Paleocene marine Usfan Formation, near Jiddah.

\section{REFERENCES}

Al-Shanti, Ahmad M.S., 1966, Oolitic iron ore deposits in Wadi Fatima between Jeddah and Mecca, Saudi Arabia: Saudi Arabian Directorate General of Mineral Resources Bulletin 2, $51 \mathrm{p}$.

Andrews, Peter, Hamilton, W.R., and Whybrow, P.J., 1978, Dryopithecines from the Miocene of Saudi Arabia: Nature, v. 274, no. 5668 , p. $249-251$.

Andrews, Peter, and Martin, L., 1987, The phyletic position of the Ad Dabtiyah hominoids: Bulletin of the British Museum (Natural History), Geology, v. 41, no. 4, p. 383-394.

Arambourg, Camille, 1952, Les Vertebres fossiles des gisements de phosphates (Maroc-Algerie-Tunisie): Service des Mines du Maroc, Rabat, Notes et Memoires, 92, p. 1-372.

Arambourg, Camille, and Joleaud, L., 1943, Vertebres fossiles du Bassin du Niger: French West Africa, Direction des Mines, Bulletin 7, p. 33-70.

Arno, V., Bakashwin, M.A., Bakor, A.Y., Barberi, F., Basahel, A., Di Paola, G.M., Ferrara, G., Gazzas, M.A., Giuliana, A., Heikel, M., Marinelli, G., Nassief, A.W., Rosi, M., and Santacroce, R., 1980, Recent volcanism within the Arabian plate, preliminary data from Harrat Hadan and Nawasif-al Buqum in Geodynamic Evolution of the Afro-Arabian Rift System: Roma, Accademia Nazionale dei Lincei, Atti dei Convegni Lincei 47, p. 629-643.

Baghanem, A.M., 1972, Geology of the lake beds near Turabah, Saudi Arabia: Rapid City, South Dakota School of Mines and Technology, M.S. thesis; see also: Saudi Arabian Directorate General of Mineral Resources, Open-File Report 488, 59 p.

Baghdadi, A.J., 1977, Prospecting for limestone around Harrat Hadan: Bureau de Recherches Geologiques et Minieres Saudi Arabian Mission Report 77 JED 26, 13 p.

Bender, Friedrich, 1975, Geology of the Arabian Peninsula, Jordan: U.S. Geological Survey Professional Paper 560-I, 36 p.

Bigelow, H.B., and Schroeder, W.C., 1948, Fishes of the western North Atlantic: New Haven, Yale University, Sears Foundation Marine Research, Memoir 1, pt. 1, 576 p.

1953, Fishes of the western North Atlantic: New Haven, Yale University, Sears Foundation Marine Research, Memoir 1, pt. 2, 588 p.

Boreske, J.R., Jr., 1974, A review of the North American fossil amiid fishes: Museum of Comparative Zoology, Harvard University, Bulletin, v. 146, no. 1, p. 1-87.

Brown, G.F., 1970, Eastern margin of the Red Sea and the coastal structures in Saudi Arabia: Royal Society of London Philosophical Transactions, Series A, v. 267, p. 75-87.

Brown, G.F., Jackson, R.O., Bogue, R.G., and Maclean, W.H., 1963, Geologic map of the Southern Hijaz quadrangle, Kingdom of Saudi Arabia: U.S. Geological Survey Miscellaneous Geologic Investigations Map I-210-A, scale 1:500,000.

Brown, G.F., Schmidt, D.L., and Huffman, A.C., Jr., 1989, Geology of the Arabian Peninsula Shield area of western Saudi Arabia: U.S. Geological Survey Professional Paper 560-A, $188 \mathrm{p}$.

Buffetaut, Eric, 1984, On the occurrence of Crocodylus pigotti in the Miocene of Saudi Arabia, with remarks on the origin of the Nile crocodile: Neues Jahrbuch für Geologie und Paläontologie, Monatshefte, 1984, Heft 9, p. 513-520. 
Cappetta, H., 1972, Les poissons crétacés et tertiaires du Bassin des Iullemmeden (République du Niger): Palaeovertebrata, v. 5, p. 179-243.

Casier, E., 1960, Note sur la collection des poissons Paléocéne et Éocéne de l'enclave de Babinda (Congo): Annales du Musée Royale du Congo Belge, A III, v. 1, no. 2, p. 1-48.

Cione, Alberto, and Laffite, Guillermo, 1980, El primer siluriform (Osteichthyes, Ostariophysi) del Cretacico de Patagonia. Consideraciones sobre el area de differenciacion de los Siluriformes-aspectos biogeographicos: in Actas del Segundo Congreso Argentino de Paleontologia y Bioestratigraphia, v. 2 , no. 2 , p. $35-46$.

Civetta, Lucia, La Volpe, Luigi, and Lirer, Lucio, 1978, K-Ar ages of the Yemen Plateau: Journal of Volcanology and Geothermal Research, v. 4, p. 307-314.

Coleman, R.G., Fleck, R.J., Hedge, C.E., and Ghent, E.D., 1975, The volcanic rocks of southwest Saudi Arabia and the opening of the Red Sea: U.S. Geological Survey Saudi Arabian Project Report 194, 60 p.

1977, The volcanic rocks of southwest Saudi Arabia and the opening of the Red Sea, in Hilpert, L.S., ed., Red Sea Research, 1970-1975. Saudi Arabian Directorate General of Mineral Resources Bulletin 22, p. D1-D30.

Coleman, R.G., Hadley, D.G., Fleck, R.J., Hedge, C.E., and Donato, M.M., 1979, The Miocene Tihama Asir ophiolite and its bearing on the opening of the Red Sea, in Tahoun, S.A., ed., Evolution and mineralization of the Arabian-Nubian Shield, v. 1: King Abdullaziz University, Institute of Applied Geology Bulletin 3, v. 1. Oxford-New York, Pergamon Press, p. 173-186.

Delany, F.M., 1954, Recent contributions to the geology of the Anglo-Egyptian Sudan: International Geological Congress, 19th, Algiers, v. 20, p. 11-18.

Frizzell, D.L., 1965, Otoliths of new fish (Vorhizia vulpes, n. gen., n. sp. Siluroidei?) from Upper Cretaceous of South Dakota: Copeia, 1965, p. 178-181.

Gentry, A.W., 1987, Ruminants from the Miocene of Saudi Arabia: Bulletin of the British Museum (Natural History), Geology, v. 41, no. 4., p. 433-440.

Glennie, K.W., and Evamy, B.D., 1968, Dikaka; plant-root structures associated with aeolian sand: Palaeogeography, Palaeoclimatology, Palaeoecology, v. 4, p. 77-87.

Gonzalez, Louis, 1973, Geologic map and sections of the Jabal 'In quadrangle: Saudi Arabian Directorate General of Mineral Resources Geologic Map GM-2, 7 p.

Grasty, R., Miller, J.A., and Mohr, P.A., 1963, Preliminary results of K-Ar age determinations, Trap Series basalts: Geophysical Observatory Addis Ababa Bulletin no. 6, (v. 3, no. 2), p. 97-101.

Greenwood, P.H., 1987, Early Miocene fish from eastern Saudi Arabia: Bulletin of the British Museum (Natural History), Geology, v. 41, no. 4, p. 451-454.

Grolier, M.J., and Overstreet, W.C., 1978, Geologic map of the Yemen Arab Republic: U.S. Geological Survey Miscellaneous Investigations Series Map I-1143 B, scale 1:500,000.

Hamilton, W.R., Whybrow, P.J., and McClure, H.A., 1978, Fauna of fossil mammals from the Miocene of Saudi Arabia: Nature, v. 274 , no. 5668 , p. $248-249$.

Jaekel, Otto, 1904, Ueber einen Torpeniden und andere Fischreste aus dem Tertiär von Kamerun, in Esch, E., Solger, F., Oppen- heim, P., and Jaekel, O., Beiträge zur Geologie von Kamerun: Stuttgart, p. 287-291.

Jones, P.W., and Rex, D.C., 1974, New dates from the Ethiopian plateau volcanics: Nature, v. 252, no. 5480, p. 218-219.

Karpoff, Roman, 1957, Sur l'existence de Maestrichtien au Nord de Djeddah (Arabie séoudite): Académie des Sciences (Paris), Comptes Rendus, v. 245, no. 16, p. 1322-1324.

Lemoalle, J., and Dupont, B., 1973, Iron-bearing oolites and the present conditions of iron sedimentation in Lake Chad (Africa), in Amstutz, G.C. and Bernard, A.J., eds., Ores in sediments: New York, Springer-Verlag, p. 167-178.

Madden, C.T., 1983, Paleocene pycnodont fishes from Jabal Umm Himar, Harrat Hadan area, Kingdom of Saudi Arabia: Saudi Arabian Deputy Ministry for Mineral Resources Open-File Report USGS-OF-03-40, 25 p.

Madden, C.T., Glennie, K.W., Whitmore, F.C., Jr., Schmidt, D.L., Ferfoglia, R.J., and Whybrow, P.J., 1982, Stegotetrabeledon (Proboscidea, Gomphotheriidae) from the Miocene of Abu Dhabi: U.S. Geological Survey Saudi Arabian Project Report, Jiddah, p. 1-22.

Madden, C.T., Naqvi, I.M., Whitmore, F.C., Jr., Schmidt, D.L., Langston, Wann, Jr., and Wood, R.C., 1979, Paleocene vertebrates from coastal deposits in the Harrat Hadan area, At Taif region, Kingdom of Saudi Arabia: U.S. Geological Survey Saudi Arabian Project Report 269, 29 p.

Madden, C.T., Schmidt, D.L., and Whitmore, F.C., Jr., 1983, Masritherium (Artiodactyla, Antdhracotheriidae) from Wadi Sabya, southwestern Saudi Arabia: an earliest Miocene age for continental rift-valley volcanic deposits of the Red Sea margin: Saudi Arabian Deputy Ministry for Mineral Resources Open-File Report USGS-OF-03-61 (Interagency Report, IR-561), 24 p.

Madden, C.T., and Whitmore, F.C., Jr., 1983, Tertiary vertebrate faunas of Arabian Peninsula: Geological Society of America Abstract with Programs, v. 15, no. 6, p. 633.

Martin, Conrad, 1969, Preliminary investigation of cement materials in the Taif area, Saudi Arabia: U.S. Geological Survey Saudi Arabian Project Report 109, 18 p.

McClure, H.A., 1978, Ar Rub'Al Khali, in Al-Sayari, S.S., and Zötl, J.G., eds., Quaternary period in Saudi Arabia: Vienna, Springer-Verlag, p. 252-263.

Meissner, C.R., Jr., and Ankary, Abdullah, 1972, Phosphorite deposits in the Sirhan-Turayf Basin, Kingdom of Saudi Arabia: Saudi Arabian Directorate General of Mineral Resources Report of Investigations 2, $27 \mathrm{p}$.

Mohr, P.A., 1975, Structural setting and evolution of Afar, in Pilger, A. and Rösler, A., Afar depression of Ethiopia: InterUnion Commission on Geodynamics, Scientific Report no. 14, v. 1. Stuttgart, E. Schweitzerbartsche Verlagsbuchhandlung, p. 27-37.

Moltzer, J.G., and Binda, P.L., 1981, Micropaleontology and palynology of the middle and upper members of the Shumaysi Formation, Saudi Arabia: King Abdulaziz University, Jiddah, Faculty of Earth Sciences Bulletin 4, p. 57-76.

Morales, J., Soria, D., and Thomas, H., 1987, Les Giraffidae (Artiodactyla, Mammalia) d'Al Jadidah du Miocene moyen de la Formation Hofuf (Province du Hasa, Arabie Saoudite): Geobios, no. 20, fasc. 4, p. 441-467.

Overstreet, W.C., Stoeser, D.B., Overstreet, E.F., and Goudarzi, G.H., 1977, Tertiary laterite of the As Sarat Mountains, Asir 
Province, Kingdom of Saudi Arabia: Saudi Arabian Directorate General of Mineral Resources Bulletin 21, 30 p.

Petters, S.W., 1978, Ancient seaway across the Sahara: The Nigerian Field, v. 42, p. 22-30.

Pickford, M., 1987, Miocene Suidae from Ad Dabtiyah, eastern Saudi Arabia: Bulletin of the British Museum (Natural History), Geology, v. 41, no. 4, p. 441-446.

Powers, R.W., Ramirez, L.F., Redmond, C.D., and Elberg, E.L., Jr., 1966, Geology of the Arabian Peninsula-sedimentary geology of Saudi Arabia: U.S. Geological Survey Professional Paper 560-D, 147 p.

Priem, M.F., 1897, Sur les poissons de l'Eocéne du Mont Mokattam (Egypte): Société Géologique de France, Bulletin, v. 25, p. 212-227.

1914, Sur les vertébrés du Cétacé et de l'Eocéne d'Egypte: Société Géologique de France, Bulletin, v. 14, p. 366-382.

Said, Rushi, 1962, The geology of Egypt: New York, Elsevier, $377 \mathrm{p}$.

Schmidt, D.L., Hadley, D.G., and Brown, G.F., 1982, Middle Tertiary continental rift and evolution of the Red Sea in southwestern Saudi Arabia: Saudi Arabian Deputy Minister for Mineral Resources Open-File Report USGS-OF-03-6 (Interagency Report, IR-503), 56 p.

Sen, S., and Thomas, H., 1979, Discovery of middle Miocene rodents in the Hofuf Formation, Hasa Province, Saudi Arabia: Société Géologique de France, Bulletin, v. 21, no. 1, supplement, p. 34-37.

Swinton, W.E., 1930, On fossil reptilia from Sokoto Province: Geological Survey of Nigeria Bulletin, v. 13, p. 15-60.

Thomas, Herbert, 1983, Les Bovidae (Artiodactyla, Mammalia) de Miocéne moyen de la Formation Hofuf (Province de Hasa, Arabie Saoudite): Montpellier, Palaeovertebrata, v. 13, no. 5, p. 157-206.

Thomas, Herbert, Roger, J., Sen, S., Bourdillon-de-Grissac, C., and Al-Sulaimani, Z., 1989, Découvertes de vertébrés fossiles dans l'Oligocéne inférieur du Dhofar (Sultanat d'Oman): Geobios, no. 22, fasc. 1, p. 101-120.

Thomas, Herbert, Sen, S., Khan, M., Battaile, B., and Ligabue, G., 1982, The lower Miocene fauna of Al-Sarar (eastern province, Saudi Arabia): Atlal, The Journal of Saudi Arabian Archaeology, v. 5, no. 3, p. 109-136.

Thomas, Herbert, Taquet, P., Ligabue, G. and Del'Agnola, C., 1978, Découverte d'un gisement de vertébrés dans les depots continentaux du Miocéne moyen du Hasa (Arabie Saoudite): Compte Rendus sommaire de la Société Géologique de France, 1978, fasc. 2, p. 69-72.
Tleel, J.W., 1973, Surface geology Damman Dome, Eastern Province, Saudi Arabia: American Association Petroleum Geologists, Bulletin, v. 57, no. 3, p. 558-576.

Tromp, S.W., 1950, The age and origin of the Red Sea graben: Geological Magazine, v. 87, p. 385-392.

Van Couvering, J.A.H., 1977, Early records of freshwater fishes in Africa: Copeia, no. 1, p. 163-166.

Wenz, S., 1969, Note sur quelques poissons actinoptérygiens de Crétacé supérieur de Bolivia: Bulletin, Société Géologique de France, v. 11, no. 7, p. 434-438.

White, E.I., 1926, Eocene fishes from Nigeria: Geological Survey of Nigeria Bulletin, v. 10, p. 1-82.

1934, Fossil fishes of Sokoto Province: Geological Survey of Nigeria Bulletin, v. 14, p. 1-78.

Whiteman, A.J., 1971, The geology of the Sudan Republic: Oxford, Clarendon Press, 290 p.

Whitmore, F.C., Jr., 1987, A delphinoid ear bone from the Dam Formation (Miocene) of Saudi Arabia: Bulletin of the British Museum (Natural History), Geology, v. 41, no. 4, p. 447-450.

Whybrow, P.J., 1984, Geological and faunal evidence from Arabia for mammal "migrations" between Asia and Africa during the Miocene, in Andrews, P., and others, eds., The early evolution of man with special emphasis on Southeast Asia and Africa: Courier Forschunginstitut Senckenberg, v. 69, p. 189-198.

comp., 1987, Miocene geology and palaeontology of Ad Dabtiyah, Saudi Arabia: Bulletin of the British Museum (Natural History), Geology, v. 41, no. 4, p. 365-457.

1989, New stratotype, the Baynunah Formation (late Miocene), United Arab Emirates, lithology and palaeontology: Newsletters on Stratigraphy, v. 21, no. 1, p. 1-9.

Whybrow, P.J., and Bassouni, M.A., 1986, The Arabian Miocene; rocks, fossils, primates and problems: 10th International Congress of Primatology, Nairobi, 1984, Proceedings, Cambridge, United Kingdom, v. 1, p. 85-89.

Whybrow, P.J., Collinson, M.E., Daams, R., Gentry, A.W., and McClure, H.A., 1982, Geology, fauna (Bovidae, Rodentia) and flora from the early Miocene of eastern Saudi Arabia: Tertiary Research, v. 4, no. 3, p. 105-120.

Whybrow, P.J., McClure, H.A., and Elliott, G.F., 1987, Miocene stratigraphy, geology and flora (Algae) of eastern Saudi Arabia and the Ad Dabtiyah vertebrate locality: Bulletin of the British Museum (Natural History), Geology, v. 41, no. 4, p. 371-382.

Wood, R.C., 1984, Evolution of the pelomedusid turtles: Studia Geologica Salamanticensia, Volume Especial 1 (Studia Palaeochelonologica I) p. 269-282. 


\section{A Paleocene Percoid Fish, Tentatively Referred to the Family Serranidae, from Jabal Umm Himar, Kingdom of Saudi Arabia}

By P.H. Greenwood

U.S. GEOLOGICAL SURVEY BULLETIN 2093-B

Prepared in cooperation with the Ministry of

Petroleum and Mineral Resources, Jiddah,

Kingdom of Saudi Arabia

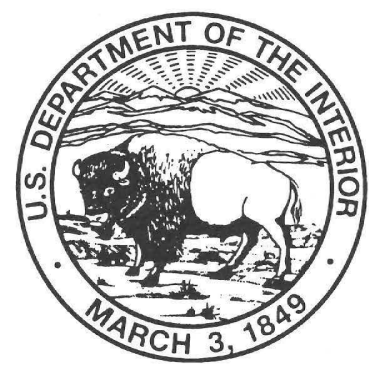




\section{CONTENTS}

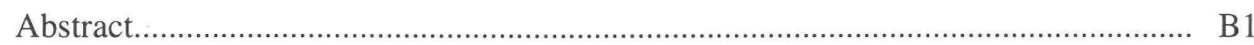

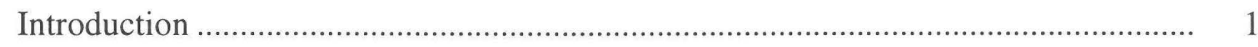

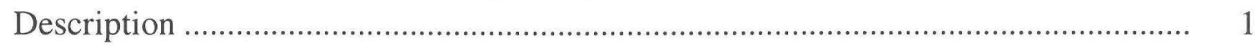

Taxonomic Position ......................................................................................... 3

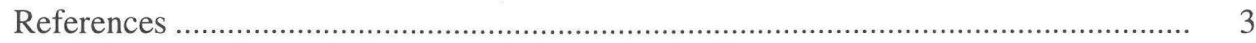

\section{FIGURES}

B1. A, entire specimen (USGS SAP 60-Per-1) in right lateral view. B, outline drawing of identifiable bones visible in right lateral view.

B2. A, entire specimen (USGS SAP 60-Per-1) in left lateral view. B, outline drawing of identifiable bones visible in left lateral view

B3. A, dorsicranium of entire specimen (USGS SAP 60-Per-1). B, outline drawing of identifiable bones in dorsicranium 


\title{
A Paleocene Percoid Fish, Tentatively Referred to the Family Serranidae, from Jabal Umm Himar, Kingdom of Saudi Arabia
}

\author{
By P.H. Greenwood ${ }^{1}$
}

\begin{abstract}
A previously unknown percoid fish, described from the Umm Himar Formation, has closest affinities to a family now known mostly from marine and brackish water of temperate and tropical regions. Related percoid fishes are known from the Paleocene of France, Sweden, and Chile.
\end{abstract}

\section{INTRODUCTION}

The holotype and sole example of Palaeopercichthys arabis Greenwood (1983, 1987 for a correction to the generic name used in 1983) is a somewhat distorted and incomplete syncranium (with part of the pectoral girdle) from a fish about $18.5 \mathrm{~cm}$ standard length. It was collected as float at the surface of locality 60 , Jabal Umm Himar, but is from the lower 2-3 $\mathrm{m}$ of the middle member of the Umm Himar Formation (see Madden and others, Chap. A, this volume). The specimen (U.S. Geological Survey SAP 60-Per-1) is temporarily deposited in the U.S. Geological Survey's Saudi Arabian collection, Department of Paleobiology, National Museum of Natural History, Washington, D.C.

\section{DESCRIPTION}

Palaeopercichthys arabis is fully described and illustrated below (figs. B1-B3), and its taxonomic affinities were discussed in Greenwood (1983).

Diagnostic features for Palaeopercichthys arabis are as follows:

A serranidlike teleost having the frontal and pterotic laterosensory canals in the form of deep and broad gutters open except for a short, partially bridged posterior section. The frontal canals of each side are separated medially by a $5 B D$ narrow but prominent wall of bone formed from each frontal. The frontal and parietal bones are without crests, but a low, anteromedially directed ridge is present on each parietal. Posteriorly, the frontals are separated by a broad tongue of the supraoccipital bone; in dorsal view the outline of the supraoccipital is roughly pyriform.

In lateral view the roof of the occipito-temporal skull region rises steeply, and is noticeably domed. The deep posttemporal fossa of each side is almost square in outline; the supratemporal fossae are shallow and, seemingly, are confined to the supraoccipital bone.

The dentigerous surface of the vomer is heart shaped; the existing alveolar scars indicate that the vomerine teeth were small and densely arranged. The palatine is a stout ploughshare-shaped bone with a deeply grooved lateral margin; alveolar scars on its dentigerous region indicate that the teeth were probably larger than those on the vomer and those situated laterally and posterolaterally on the premaxilla.

The premaxilla is about four-fifths the length of the maxilla. It carried a fine felt of small teeth, probably extending the entire length of its lateral dentigerous face; a few, somewhat larger, teeth seem to have been present anteriorly. There is, apparently, no supramaxilla. The maxilla extends to the level of the vertical through the anterior orbital margin.

Regrettably, no elements of the lower jaw are preserved. It is thought, from the orientation of the quadrate (after making due allowances for distortion), that the lower jaw sloped upwards at an angle of about 30 degrees to the horizontal.

All identifiable elements of the infraorbital series are relatively deep bones when compared with those from extant serranid and percichthyid taxa. A large suborbital shelf is present on the presumed third infraorbital bone. It is impossible to determine whether or not any of the infraorbital bones preserved had a serrated ventral margin.

The outer margins of bones in the opercular series apparently are without spines, serrations, or deep indentations, but the operculum probably carried a single, bluntly rounded spine on its dorsoposterior border. 


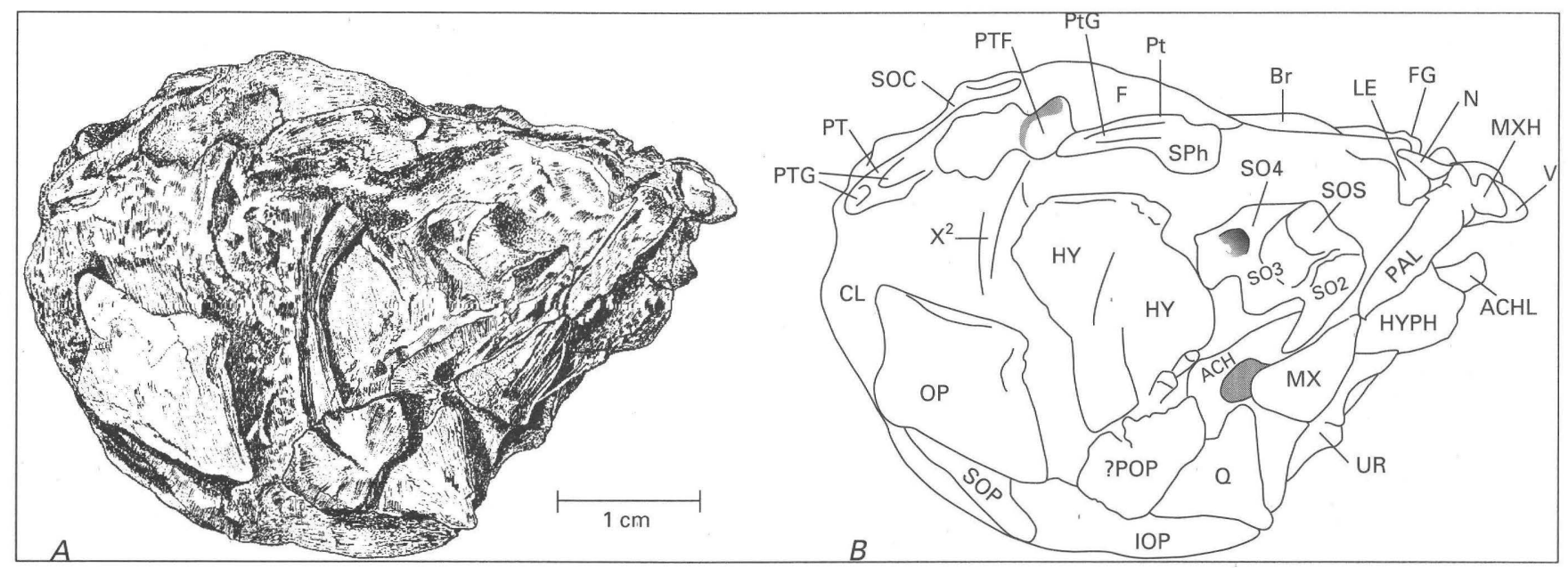

Figure B1. A, entire specimen (USGS SAP 60-Per-1) in right, lateral view. When in situ on vertebral column, dorsal roof of skull would slope upwards from vomer at angle of about 40-45 degrees to horizontal (and not lie almost horizontally as depicted here). $B$, outline drawing of identifiable bones visible in right lateral view. $\mathrm{ACH}$, anterior ceratohyal; $\mathrm{ACHL}$, tip of anterior ceratohyal (left); $\mathrm{Br}$, bridge across posttemporal laterosensory canal groove; $\mathrm{CL}$, cleithrum; CLH, head of cleithrum; EOC, epioccipital; F, frontal; $\mathrm{FG}$, laterosensory canal groove in frontal; $\mathrm{FBr}$, base of bridge across frontal laterosensory canal groove; HY, hyomandibula; HYPH, hypohyals; IOP, interoperculum; LE, lateral ethmoid; MX, maxilla; MXH, head of maxilla; N, nasal; OP, operculum;
OPS, ? opercular spine; PAL, palatine; PAR, parietal; PMX, premaxilla; PMXA, ascending process of premaxilla; POP, preoperculum; PR, ridge on parietal; PT, posttemporal; PTF, posttemporal fossa; PTG, laterosensory canal groove on posttemporal; $\mathrm{Pt}$, pterotic; $\mathrm{Ptg}$, laterosensory canal groove on pterotic; Q, quadrate; SE, supraethmoid; SO, suborbital bones; $\mathrm{SO}$, 2nd suborbital bone; SO3, 3rd suborbital bone; SO4, ?4th suborbital bone; SOC, supraoccipital bone; SOCC, supraoccipital crest (ridgelike portion); SOP, suboperculum; SOS, suborbital shelf on 3rd suborbital bone; SPh, sphenotic; UR, urohyal; V, vomer; $\mathrm{X}^{1}$, unidentified bone, possibly part of pterygoid arch; and $\mathrm{X}^{2}$, unidentified bone, possibly part of hyomandibula.

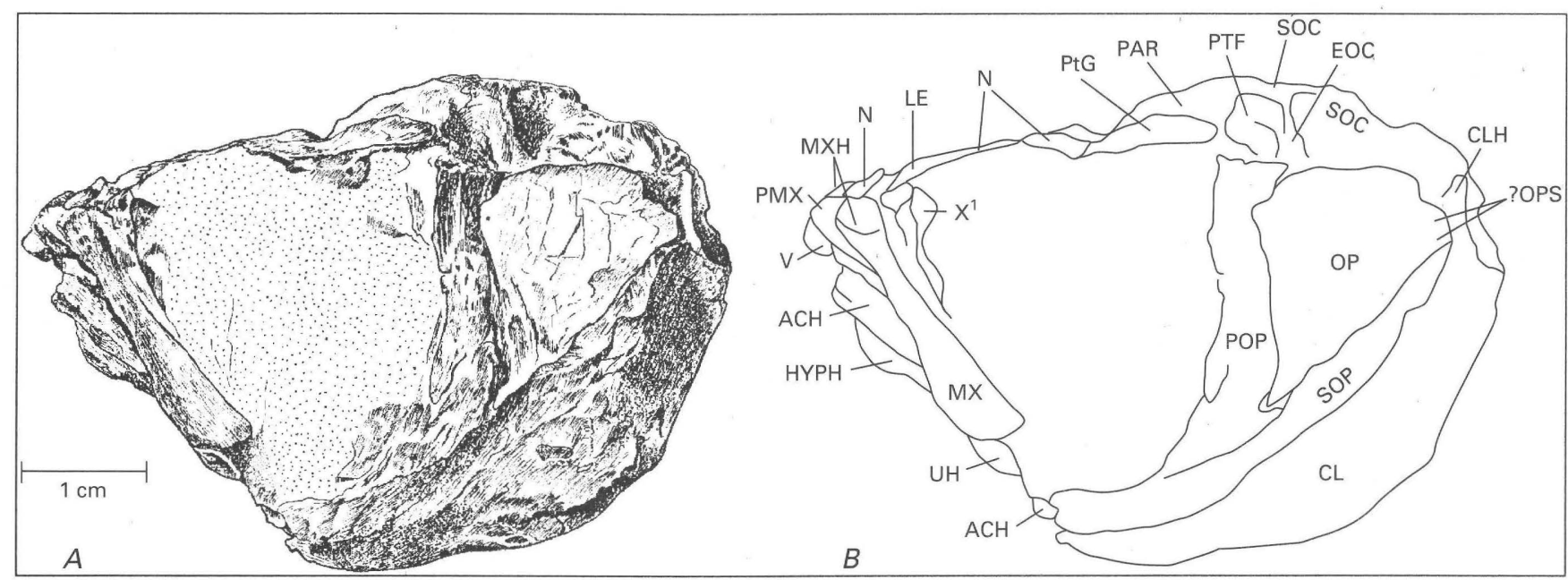

Figure B2. A, entire specimen (USGS SAP 60-Per-1) in left lateral view. Matrix-filled orbital region is indicated by stippling. $B$, outline drawing of identifiable bones visible in left lateral view. Abbreviations as in fig. B1. 


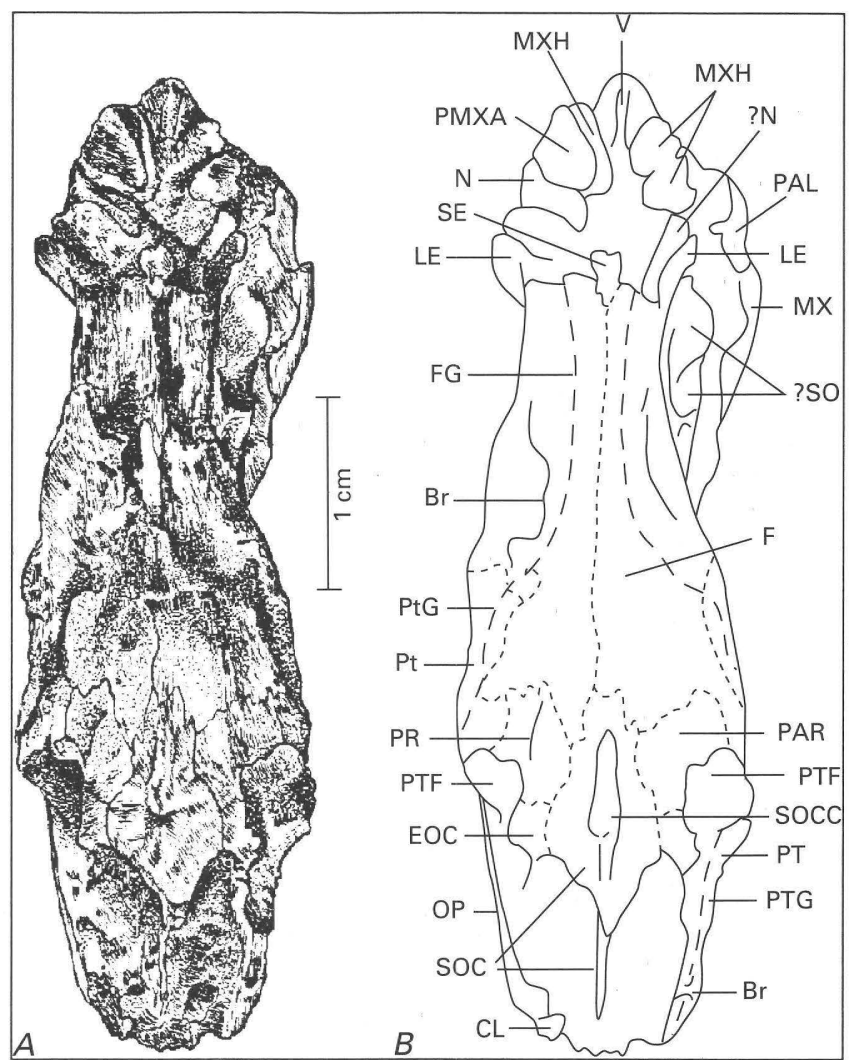

Figure B3. $A$, dorsicranium of entire specimen (USGS SAP 60Per-1). $B$, outline drawing of identifiable bones in dorsicranium. Sutures are indicated by dotted lines; the course of frontal and pterotic laterosensory canal systems is indicated by dashed lines. Abbreviations as in fig. B1.

\section{TAXONOMIC POSITION}

Enough diagnostic characters are preserved in the holotype to warrant the assignment of Palaeopercichthys arabis to the perciform suborder Percoidei. Its familial assignment is, however, far less certain. On the basis of overall similarity, the visible syncranial features seem to suggest affinity with certain extant members of the families Serranidae and Percichthyidae. Unfortunately the nature and condition of the specimen preclude its detailed comparison with the few recorded Paleocene serranids and percichthyids known, for the families respectively, from France, Sweden, and Chile (see Arratia 1982).
Extant percichthyids have a wide distribution in marine, brackish, and fresh waters of tropical and temperate regions; living serranids, too, are widely distributed in tropical and temperate regions but with only a few taxa occurring in freshwater habitats. Interestingly, Palaeopercichthys arabis shares certain derived features with an extant freshwater percichthyid from Australia (Plectroplites ambigua), namely the steeply upswept profile to the postorbital skull roof and that area's inflated appearance. The fossil shares with another extant percichthyid, Perichthys trucha from Chilean fresh waters, the apparently derived feature of open, gutterlike fronto-pterotic lateral-line canals. The significance, in a phylogenetic sense, of these resemblances cannot be evaluated since the only specimen of Palaeopercichthys arabis is both incomplete and damaged, thus not revealing any of the diagnostic features that would allow its certain placement in either the Percichthyidae or the Serranidae. The visible characteristics that it shares with the Serranidae (as currently defined) are its generally plesiomorphic jaw morphology and overall similarity with that family in its syncranial organization and morphology. The absence from the specimen (either morphologically or because of its incompleteness) of features presumed to be diagnostic for other basal percoid families adds to the difficulty of assigning the taxon to a definite place in this confused area of percoid taxonomy.

With this level of uncertainty, and because of the syncranial anatomy having an overall serranidlike facies, the taxon is tentatively referred to the Serranidae.

\section{REFERENCES}

Arratia, G., 1982, A review of freshwater percoids from South America (Pisces, Osteichthyes, Perciformes, Percichthyidae and Perciliidae): Abhandlungen der Senckenbergischen Naturforschenden Gesellschaft, 540, p. 1-52.

Greenwood, P.H., 1983, A new Palaeocene fish from Saudi Arabia: Journal of Natural History, v. 17, no. 3, p. 405-418.

1987, A replacement name for Parapercichthys Greenwood (1983), a junior homonym: Copeia, no. 3, p. 787.

Madden, C.T., Naqvi, I.M., Whitmore, F.C., Jr., Schmidt, D.C., Langston, Wann, Jr., and Wood, R.C., 1979, Paleocene vertebrates from coastal deposits in the Harrat Hadan area, At Taif region, Kingdom of Saudi Arabia: U.S. Geological Survey Saudi Arabian Project Report 269, 29 p. 


\title{
Paleocene Amiid Fish from Jabal Umm Himar, Kingdom of Saudi Arabia
}

\author{
By Mark V.H. Wilson
}

PALEOCENE VERTEBRATES FROM JABAL UMM HIMAR, KINGDOM OF SAUDI ARABIA

U.S. GEOLOGICAL SURVEY BULLETIN 2093-C

Prepared in cooperation with the Ministry of

Petroleum and Mineral Resources, Jiddah,

Kingdom of Saudi Arabia

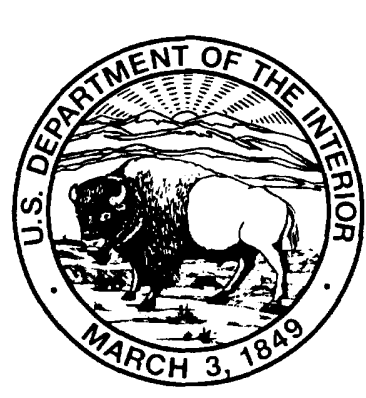




\section{CONTENTS}

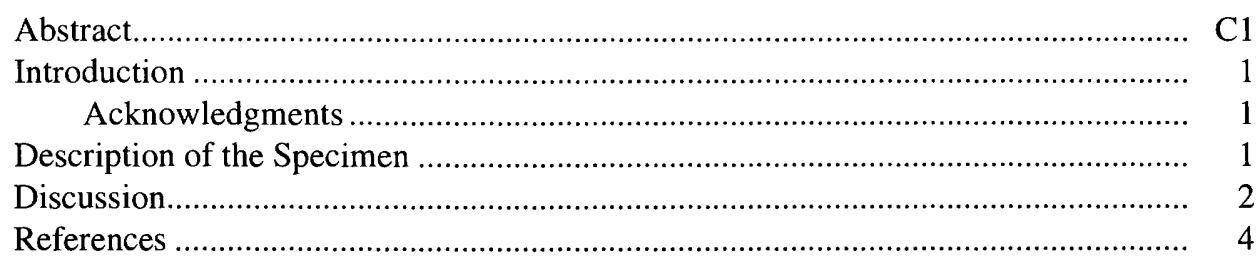

\section{PLATE}

[Plate follows references]

C1. The Saudi Arabian fossil amiid centrum compared with certain other fossil centra.

\section{FIGURE}

C1. Histological detail of USGS SAP 2-Am-1 in transverse section in the region of neural-arch facets 


\title{
Paleocene Amiid Fish from Jabal Umm Himar, Kingdom of Saudi Arabia
}

\author{
By Mark V.H. Wilson ${ }^{1}$
}

\begin{abstract}
A single vertebral centrum from the Paleocene Umm Himar Formation near Turabah, Saudi Arabia, represents the first Tertiary record of the Amiidae from the Arabian Peninsula. The centrum resembles an anterior diplospondylous caudal centrum of Amia or Kindleia in proportions and histology, but differs in being much larger, in being more circular, and in having hemispherical arch facets. It is probably not congeneric with any described amiid of Tertiary age, but with discovery of additional material the Saudi Arabian amiid might prove to be closely related to one of the genera of large-bodied amiids with ossified vertebrae known from Cretaceous formations.
\end{abstract}

\section{INTRODUCTION}

Among the Paleocene fossil vertebrates collected from Jabal Umm Himar, Kingdom of Saudi Arabia (Greenwood, 1983; Madden and others, 1979; Chap. A, this volume), is a single broken vertebral centrum. This report establishes that the centrum represents an amiid fish, and discusses the taxonomic, stratigraphic, and biogeographic significance of this identification.

The fossil, USGS SAP 2-Am 1, was collected in 1974 from locality 2 of the Jabal Umm Himar local fauna (Madden and others, 1979, Chap. A, this volume, fig. A2). The site is in the lower few meters of the middle mudstone and shale unit of the Umm Himar Formation, at $21^{\circ} 11.3^{\prime} \mathrm{N}$, $41^{\circ} 30.8^{\prime} \mathrm{E}, 3 \mathrm{~km}$ northeast of Jabal Umm Himar.

The fossil centrum is probably of Paleocene age and almost certainly not older than latest Cretaceous or younger than Eocene, based on first and last appearances of taxa found at various Umm Himar fossil localities. At locality 2 the centrum was preserved with remains of torpedos (Turpedininae), eagle rays (Myliobatidae), catfishes (Siluriformes), and mesosuchian crocodilians (Hyposaurus nopcsais, Rhabdognathus compressus, and Rhabdognathus

'Department of Zoology and Laboratory for Vertebrate Pảleontology, The University of Alberta, Edmonton, Alberta T6G 2E9 Canada. sp.), an assemblage suggestive of estuarine habitats. The taxa found at other Umm Himar sites indicate estuarine or lagoonal conditions, with abundant sharks, eagle rays, catfishes, a percoid, side-necked turtles, and crocodilians, along with rare pycnodonts, lungfish, and perciforms (Greenwood, 1983; Madden and others, 1979, Chap. A, this volume). A tropical climate at the time of deposition is suggested by the presence of iron oolites within the Umm Himar Formation and by laterite developed on the unconformity that constitutes the top of the formation (Madden and others, 1979, Chap. A, this volume).

\section{ACKNOWLEDGMENTS}

I thank C.T. Madden and F.C. Whitmore, Jr., for arranging for my study of the specimen, and Richard Stucky and Joseph Nelson for reading a draft of the manuscript. Allan Lindoe helped with specimen preparation. This research was supported in part by Natural Sciences and Engineering Research Council of Canada operating grant A9180 to the author.

\section{DESCRIPTION OF THE SPECIMEN}

The centrum is incomplete, having been broken along an oblique plane passing through the middle of the bone (pl. $\mathrm{C} 1$, fig. 1). The sagittal plane of the centrum is indicated by the presence of two hemispherical excavations that are interpreted as neural or haemal arch facets (pl. C1, figs. 2-5).

It is difficult to orient the centrum correctly because there is no reliable indicator of either anterior or dorsal directions. However, for the purposes of this description the arch facets will be interpreted as neural-arch facets. The inferred neural-arch facets are closer to one face of the centrum than to the other, and the face that is more distant from the facets is presumed to be the anterior face (pl. C1, fig. 1; figs. 2, 3 toward the left).

The centrum is $15 \mathrm{~mm}$ thick (anteroposteriorly), and when complete was about $29 \mathrm{~mm}$ wide and about $34 \mathrm{~mm}$ high. It is amphicoelous and imperforate, with the anterior 


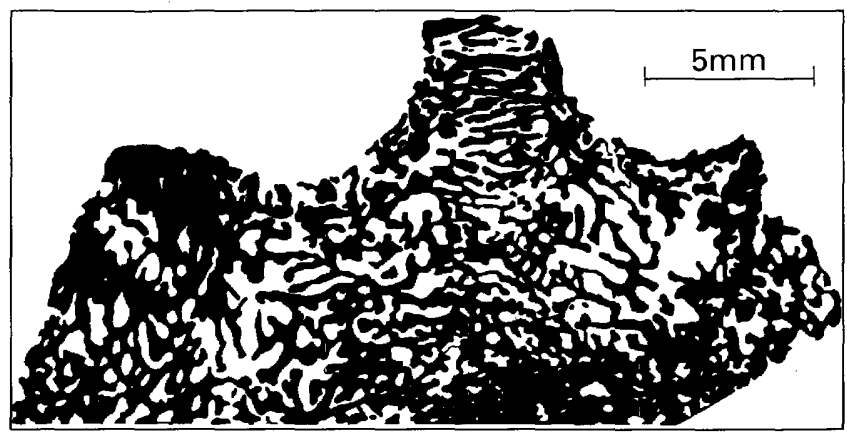

Figure C1. Histological detail of USGS SAP 2-Am-1 in transverse section in the region of neural-arch facets, drawn by camera lucida, bone shown in black, pore spaces in white. The section is incomplete in the lower right and upper right because of breakage of the specimen.

and posterior faces having conical caps of lamellar bone that are thicker at their rims than at their centers. These caps show concentric growth rings externally (pl. C1, fig. 1) and definite growth layers in cross section (pl. C1, fig. 2). The external surface of the centrum, apart from the anterior and posterior faces, has a porous, incomplete (partly eroded) layer of lamellar bone that covers porous bone beneath.

In transverse section the centrum consists of porous bone (pl. C1, figs. 4, 5). The porosity is greatest beneath the arch facets and decreases toward the middle of the centrum (fig. C1). The less porous parts have been secondarily filled by additional bone.

A distinctive feature is the histology of the bone between the arch facets, where layers result from the alternation of bony lamellae and intervening spaces. The bony lamellae and other bony partitions throughout the centrum are themselves layered on a small scale. These small-scale layers are interpreted as growth increments, and are parallel to the walls of the pore spaces.

\section{DISCUSSION}

The centrum is assigned to the Amiidae on the basis of external proportions and histology in transverse section. The list of taxa with which the centrum has been compared includes both freshwater and marine fishes known to have been extant during latest Cretaceous to early Tertiary times.

Late Cretaceous and early Tertiary freshwater and marine fishes of Africa and the Arabian peninsula (including fauna from Israel and Lebanon) consist of Elasmobranchii, Polypteridae, Lepidosirenidae, Ceratodontidae, Lepisosteidae, Pycnodontidae, Amiidae, and various Teleostei (Chap. A, this volume; Chalifa, 1989; Chalifa and Tchernov, 1982; de Broin and others, 1974; Greenwood, 1974, 1983; Van Couvering, 1977; Wiley, 1976). The Polypteridae and Lepisosteidae have vertebrae with distinctive shapes not at all similar to the fossil centrum in question. The Ceratodontidae, Lepidosirenidae and Pycnodontidae lack ossified centra, although some Devonian lungfish have them (Schultze, 1970). The calcified centra of elasmobranchs have a variety of shapes (Applegate, 1967), including spool-shaped forms with hemispherical arch facets, but all are concentrically laminated and radially fibrous in transverse section (pl. C1, fig. 9).

Teleostean vertebral centra are for the most part longer and more constricted, having prominent longitudinal ridges. However, some teleostean centra, such as those of primitive salmoniforms, approach the Saudi Arabian centrum in shape, including the possession of hemispherical arch facets. The similarity does not extend to histological features seen in transverse section; prominent radiating struts of dense bone characterize the teleostean centra (Schaeffer, 1967; pl. C1, fig. 6), but are not seen in the Saudi Arabian fossil.

The Saudi Arabian fossil centrum is, however, closely approximated in external form and histology by centra of the Amiidae, a family with a long fossil history but a single extant freshwater species in North America (Schultze and Wiley, 1984). I have compared the Saudi Arabian fossil with centra of Amia and with the Late Cretaceous to early Tertiary genus Kindleia, included within Amia by some authors (Janot, 1967; Boreske, 1974; Gaudant, 1980), and synonymized with Cyclurus Agassiz by Gaudant (1987). Centra of these genera are imperforate, amphicoelous, higher and wider than long, and have a slightly porous appearance externally. In transverse section the centra of Amia and Kindleia are composed of spongy bone (Schaeffer, 1967), resembling that of the Saudi Arabian fossil in detail (pl. C1, figs. 4, 5, 7, 8). Among the striking similarities are the greater porosity of bone beneath the arch facets, and the layered appearance of bony lamellae and intervening spaces between the arch bases ( $p l . \mathrm{C} 1$, figs. 5, 7). I therefore conclude that the Saudi Arabian fossil belongs within the Amiidae.

In Amia and Kindleia the shape of the centrum differs markedly from one end of the vertebral column to the other (Boreske, 1974). Trunk vertebrae are wider than they are high, and relatively longer than are caudal centra. Diplospondylous caudal centra are in turn shorter than monospondylous caudal centra (Boreske, 1974, fig. 14). The proportions of the Saudi Arabian fossil are closest to those of diplospondylous caudal centra of Amia or Kindleia near the front of the diplospondylous series.

However, there are important differences between the Saudi Arabian fossil and the known species of Amia and Kindleia: size and shape of the centrum, and shape of neural facets. The fossil is large compared to all known Kindleia and almost all known Amia. Although data are not available for all species, the estimated height and width of the Saudi Arabian fossil are approached only by the largest specimens of Amia uintaensis, a Late Cretaceous to early Tertiary 
species from North America (Boreske, 1974), and by Amia? chauliodeia Hall and Wolberg 1989, a Late Cretaceous species from North America. Second, in Amia and Kindleia, caudal centra approach a rectangular shape and neural and haemal arch facets are elongated anteroposteriorly and often subrectangular or hourglass shaped (Janot, 1967, pl. xi, fig. 5; Boreske, 1974, fig. 11) rather than hemispherical.

It seems clear from these differences that the Saudi Arabian amiid is not congeneric with either Amia or Kindleia, both of which occur in Cretaceous and early Tertiary freshwater deposits in North America (Hall and Wolberg, 1989; Wilson, 1982) and Eurasia (Boreske, 1974; Janot, 1967). Late Cretaceous forms other than Amia and Kindleia include disarticulated skull bones and vertebrae reported by de Broin and others (1974) from lower Senonian continental deposits of Nigeria and said to be similar to Amia; Pachyamia, a genus with ossified centra and diplospondyly, reported by Chalifa and Tchernov (1982) from Cenomanian lagoonal or marine deposits of Israel; and Melvius, a large-bodied amiid described by Bryant (1987) from disarticulated but associated remains in the fluvial uppermost Cretaceous Hell Creek Formation of North America. Another genus in the family is Urocles, from the Jurassic and Lower Cretaceous of Europe (Lange, 1968) and the Cretaceous of Brazil (Santos, 1960). The amiid Enneles is also known from Brazil (Santos, 1960), from the Santana Formation of Ceara, and is probably of Early Cretaceous (Aptian) age (Forey, 1977). Also often included within the Amiidae (Patterson, 1973; Chalifa and Tchernov, 1982) are the Jurassic and (or) Early Cretaceous genera Amiopsis, Ikechaoamia, Liodesmus, Sinamia, and Vidalamia, all of which occur in the Northern Hemisphere: North America, Europe, northern China and Mongolia (Chalifa and Tchernov, 1982; Zhang and Zhang, 1980; Li, 1984; Liu and Su, 1983). All of these taxa are older than Tertiary.

According to Patterson (1973) and Chalifa and Tchernov (1982), ossified centra arose within the Amiidae-if the Late Jurassic Liodesmus, which lacks centra, is correctly interpreted as an amiid. Further, most Jurassic and Cretaceous amiids had diplospondyly in the caudal region (Schaeffer, 1960; Chalifa and Tchernov, 1982), as did Atacamichthys, a Jurassic teleost from Chile not classified as an amiid or even as a halecomorph (Arratia and Schultze, 1987).

Although most or all of these genera had ossified centra, too little is known about details of their vertebral anatomy to permit meaningful comparisons with the Saudi Arabian fossil. A partial exception is Melvius, which had caudal centra very similar to but much larger than those of Amia, that is, comparable in size to the Saudi Arabian fossil but more like Amia in shape. Atacamichthys centra have been studied in transverse section (Arratia and Schultze, 1987), and do not resemble the Saudi Arabian fossil. Any of the other genera with ossified centra could be relatives of the Saudi Arabian amiid.

To summarize the above discussion, the fossil represents an amiid with vertebral anatomy similar in histology and proportions to Amia, Kindleia, and Melvius, comparable in size to Melvius and some species of Amia but differing from all three in overall shape and in shape of arch facets. In view of the anatomical differences between the new fossil and Amia, Kindleia, and Melvius, and the geologic age differences between the new fossil and all other known amiids, it is unlikely that the Saudi Arabian fossil represents a species that has been named. However, I have refrained from describing a new taxon on the basis of the single fossil centrum because it has been shown that many previous descriptions of amiid species, based on vertebral characters, are not specifically distinct (Boreske, 1974).

Although all previously reported latest Cretaceous, Tertiary, and Holocene amiids are freshwater fish, there is some doubt about whether earlier amiids are all freshwater fish, as stated by Chalifa and Tchernov (1982), or whether some were marine. Although some appear to be in continental deposits (Maisey, 1990), the freshwater status of other deposits is doubtful.

There is also doubt about the habitat of the Saudi Arabian amiid, a fact that restricts its usefulness for interpreting the biogeographic history of the family. The fossil locality is thought to represent an estuary at the southern extremity of a marine transgression from the Tethys Sea to the north (Madden and others, 1979; Chap. A, this volume). Although some marine taxa are included in the assemblage, several others are more probably of freshwater origin. If the Saudi Arabian amiid proves to be marine, it would be the geologically youngest marine amiid known.

Although separated from Africa by shallow seaways during various parts of its Mesozoic history, the Arabian Peninsula is usually considered to be part of or connected to the African plate (Smith and others, 1981; Lillegraven and others, 1979). If, as seems likely, the Saudi Arabian amiid was a freshwater fish, it represents the most recent occurrence of freshwater amiids on the African land mass. The family is otherwise missing from the African Tertiary record (Greenwood, 1974; Van Couvering, 1977). Because amiids have been reported from the lower Senonian of Nigeria (de Broin and others, 1974), it is possible that they have a long independent history in Africa similar to that inferred for gars by Wiley (1976). However, in view of the post-Early Jurassic breakup of Pangea and the earliest records of the family in the Jurassic, it is possible that the Saudi Arabian fossil amiid represents a lineage that survived on the African plate and its connected fragments after isolation from its sister group in either Eurasia or South America.

A further possibility is that amiids gained access to Africa-Arabia at a time significantly later than the early divergence of the family, perhaps from Eurasia, after the 
last continental connections between South America and Africa were broken in about the late Albian to Turonian time interval (Lillegraven and others, 1979). Some terrestrial fossil vertebrates have a distribution that suggests Laurasian-African connections during the Cretaceous, as for example the occurrence of a pachycephalosaurid dinosaur in the Upper Cretaceous of Madagascar (Sues, 1980). The question of amiid history in Africa and the Arabian Peninsula cannot be confidently answered on present evidence, although a better understanding of the phylogenetic relationships of the Saudi Arabian amiid would help, as would efforts to find additional amiid fossils in African and Arabian deposits of Cretaceous and early Tertiary age.

\section{REFERENCES}

Applegate, S.P., 1967, A survey of shark hard parts, in Gilbert, P., Mathewson, R.F., and Rall, D.P., eds., Sharks, skates and rays: Johns Hopkins Press, p. 36-67.

Arratia, G., and Schultze, H.P., 1987, A new halecostome fish (Actinopterygii, Osteichthyes) from the Late Jurassic of Chile and its relationships, in Martin, J.E., and Ostrander, G.E., eds., Papers in Vertebrate Paleontology in Honor of Morton Green: Dakoterra, v. 3, p. 1-13.

Boreske, J.R., Jr., 1974, A review of the North American fossil amiid fishes: Museum of Comparative Zoology, Harvard University, Bulletin, v. 146, no. 1, p. 1-87.

Bryant, L.J., 1987, A new genus and species of Amiidae (Holostei; Osteichthyes) from the Late Cretaceous of North America, with comments on the phylogeny of the Amiidae: Journal of Vertebrate Paleontology, v. 7, no. 4, p. 349-361.

de Broin, F., Buffetaut, E., Koeniger, J.C., Rage, J.C., Russell, D., Taquet, P., Vergnaud-Grazzini, C., and Wenz, S., 1974, La faune de vertébrés continentaux du gisement d'In Beceten (Sénonien du Niger): l'Académie des Sciences (Paris), Comptes Rendus, v. 279D, p. 469-472.

Chalifa, Y., 1989, Two new species of longirostrine fishes from the lower Cenomanian (Late Cretaceous) of Ein-Yabrud, Israel, with comments on the phylogeny of the Dercetidae: Journal of Vertebrate Paleontology, v. 9, no. 3, p. 314-328.

Chalifa, Y., and Tchernov, E., 1982, Pachyamia latimaxillaris, new genus and species (Actinopterygii: Amiidae), from the Cenomanian of Jerusalem: Journal of Vertebrate Paleontology, $v$. 2 , no. 3, p. 269-285.

Forey, P.L., 1977, The osteology of Notelops Woodward, Rhacolepis Agassiz and Pachyrhizodus Dixon (Pisces: Teleostei): British Museum (Natural History) Geology, Bulletin, v. 28, no. 2, p. 123-204.

Gaudant, J., 1980, Sur Amia kehreri (Poisson Amiidae du Lutétien de Messel, Allemagne) et sa signification paléogéographique: l'Académie des Sciences (Paris), Comptes Rendus, v. 290D, p. 1107-1110.

1987, Mise au point sur certains poissons Amiidae du Cénozoïque européen: le genre Cyclurus Agassiz (=Kindleia Jordan): Paläontologische Zeitschrift, v. 61, p. 321-330.

Greenwood, P.H., 1974, Review of Cenozoic freshwater fish faunas in Africa: Geological Survey of Egypt, Annals, v. 4, p. 211-231.
1983, A new Palaeocene fish from Saudi Arabia: Journal of Natural History, v. 17, no. 3, p. 405-418.

Hall, J.P., and Wolberg, D.L., 1989, A new Late Cretaceous (Campanian-Maastrichtian) amiid (Halecomorphi; Actinopterygii) from the Fruitland Formation, San Juan Basin, New Mexico: Journal of Paleontology, v. 63, no. 1, p. 108-115.

Janot, C., 1967, A propos des amiidés actuels et fossiles: Colloques Internationales du Centre National de la Recherche Scientifique, v. 163, p. 139-153.

Lange, S.P., 1968, Zur morphologie und taxonomie der fischgattung Urocles aus Jura und Kreide Europas: Palaeontographica, v. 131A, p. 1-78.

Lillegraven, J.A., Kraus, M.A.J., and Bown, T.M., 1979, Paleogeography of the world of the Mesozoic, in Lillegraven, J.A., Kielan-Jaworowska, Z., and Clemens, W.A., eds., Mesozoic mammals: the first two-thirds of mammalian history: University of California Press, p. 277-308.

Li Guo-qing, 1984, Discovery of Sinamia from East Jilin: Vertebrata Palasiatica, v. 22, p. 145-150.

Liu Hsien-ting, and Su De-zao, 1983, Fossil amiids (Pisces) of China and their biostratigraphic significance: Palaeontologica Polonica, v. 28, p. 181-194.

Madden, C.T., Naqvi, I.M., Whitmore, F.C., Jr., Schmidt, D.L., Langston, Wann, Jr., and Wood, R.C., 1979, Paleocene vertebrates from coastal deposits in the Harrat Hadan area, At Taif region, Kingdom of Saudi Arabia: U.S. Geological Survey Saudi Arabian Project Report 269, 29 p.

Maisey, J.G., 1990, Stratigraphy and depositional environment of the Crato Member (Santana Formation, Lower Cretaceous of N.E. Brazil), in Grimaldi, D.A., ed., Insects from the Santana Formation, Lower Cretaceous, of Brazil: Bulletin of the American Museum of Natural History, no. 195, p. 15-19.

Patterson, C., 1973, Interrelationships of holosteans, in Greenwood, P.H., Miles, R.S., and Patterson, C., eds., Interrelationships of fishes: Zoological Journal of the Linnean Society, v. 53, suppl. 1, p. 233-305.

Santos, R.S., 1960, A posição sistemática de Enneles audax Jordan e Branner da Chapada do Araripe, Brasil: Divisão de Geologia e Mineralogia, Monografia, v. 17, p. 1-25.

Schaeffer, B., 1960, The Cretaceous holostean fish Macrepistius: American Museum Novitates, no. 2011, 18 p.

1967, Osteichthyan vertebrae, in Patterson, C., and Greenwood, P.H., eds., Fossil vertebrates: Journal of the Linnaean Society of London (Zoology), v. 47, no. 311, p. 185-195.

Schultze, H.P., 1970, Die Histologie der Wirbelkörper der Dipnoer (The histological structure of the centra of dipnoans): Neues Jahrbuch für Geologie und Paläontologie, Abhandlungen, v. 135, no. 3, p. 311-336.

Schultze, H.P., and Wiley, E.O., 1984, The neopterygian Amia as a living fossil, in Eldredge, N., and Stanley, S.M., eds., Living fossils: New York, Springer Verlag, p. 153-159.

Smith, A.G., Hurley, A.M., and Briden, J.C., 1981, Phanerozoic paleocontinental world maps: Cambridge, Cambridge University Press, $102 \mathrm{p}$.

Sues, H.D., 1980, A pachycephalosaurid dinosaur from the Upper Cretaceous of Madagascar and its paleobiogeographical implications: Journal of Paleontology, v. 54, no. 5, p. 954-962.

Van Couvering, J.A.H., 1977, Early records of freshwater fishes in Africa: Copeia, 1977, no. 1, p. 163-166. 
Wiley, E.O., 1976, The phylogeny and biogeography of fossil and Recent gars (Actinopterygii: Lepisosteidae): University of Kansas Museum of Natural History, Miscellaneous Publication, no. 64, p. 1-111.

Wilson, M.V.H., 1982, A new species of the fish Amia from the Middle Eocene of British Columbia: Palaeontology, v. 25, no. 2, p. 413-424.
Zhang, Mi-man, and Zhang, Hong, 1980, Discovery of Ikechaoamia from South China: Vertebrata Palasiatica, v. 18, no. 2, p. 89-93. 

PLATE 


\section{Plate C1}

[The Saudi Arabian fossil amiid centrum compared with certain other fossil centra]

Figures 1-5. Fossil amiid centrum from Jabal Umm Himar, USGS SAP 2-Am-1.

1. Anterior view, showing growth rings on anterior face.

2. Lateral view, showing left neural facet (arrow).

3. Dorsolateral view, showing right (upper arrow) and left (lower arrow) neural facets.

4. Entire specimen in transverse section.

5. Detail of transverse section showing circular profile of the neural facets, porosity beneath facets, and alternating bony lamellae and planar pore spaces between facets.

6-9. Comparative fossil centra in transverse section.

6. UALVP (University of Alberta, Laboratory for Vertebrate Paleontology) 15488, probable salmoniform centrum from Upper Cretaceous Vermilion River Formation, Manitoba, Canada, showing radiating bony struts.

7. UALVP 10833, caudal centrum of Kindleia fragosa Jordan, from Paleocene Paskapoo Formation, Alberta, Canada.

8. UALVP 13862, trunk centrum of a large Kindleia fragosa, from Paleocene Paskapoo Formation, Alberta, Canada.

9. UALVP 70, a spool-shaped centrum possibly of the ray Myledaphus sp., from Upper Cretaceous Horseshoe Canyon Formation, Alberta, Canada, showing concentric rings typical of chondrichthyan centra. 



\section{A Paleocene Lungfish, Ceratodus humei \\ Priem 1914, from Jabal Umm Himar, Kingdom of Saudi Arabia}

By Frank C. Whitmore, Jr.

U.S. GEOLOGICAL SURVEY BULLETIN 2093-D

Prepared in cooperation with the Ministry of

Petroleum and Mineral Resources, Jiddah,

Kingdom of Saudi Arabia

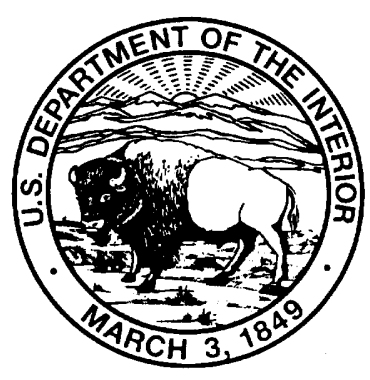

UNITED STATES GOVERNMENT PRINTING OFFICE, WASHINGTON : 1995 


\section{CONTENTS}

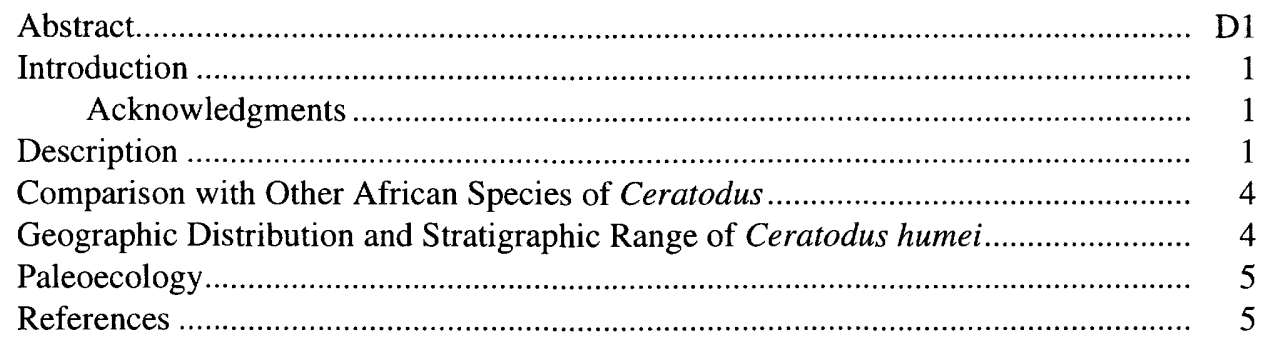

\section{FIGURES}

D1. Index map of western Saudi Arabia showing location of the Jabal Umm Himar area

D2. Right pterygo-palatine tooth of Ceratodus humei. 


\title{
A Paleocene Lungfish, Ceratodus humei Priem 1914, from Jabal Umm Himar, Kingdom of Saudi Arabia
}

\author{
By Frank C. Whitmore, Jr. ${ }^{1}$
}

\begin{abstract}
A single pterygo-palatine tooth of a large lungfish, identified as Ceratodus humei Priem 1914, was collected from the Umm Himar Formation of Paleocene age in the Harrat Hadan area, At Taif region, in the western part of the Kingdom of Saudi Arabia. It was associated with crocodilian remains in a fauna that also includes sharks, rays, bony fishes, and turtles. The fauna indicates an estuarine or lagoonal environment. The presence of a single lungfish specimen, in contrast to the large numbers of lungfish found in probable lake beds of Cretaceous and Paleocene age in the Sahara, points to the probability that the Saudi Arabian specimen was transported, before burial, from a nearby body of fresh water.

The geographic range of Ceratodus humei extends from Morocco to western Saudi Arabia; the geologic range of $C$. humei sensu stricto is from Lower Cretaceous to Paleocene.
\end{abstract}

\section{INTRODUCTION}

A single right pterygo-palatine tooth of a large lungfish was collected by Cary T. Madden on July 31, 1976, from the Umm Himar Formation of Paleocene age in the Harrat Hadan area, At Taif region, Kingdom of Saudi Arabia (fig. D1). The specimen was found at locality 34 , about $2 \mathrm{~km}$ north-northeast of Jabal Umm Himar, at lat $21^{\circ} 11^{\prime} \mathrm{N}$., long $41^{\circ} 24.3^{\prime} \mathrm{E}$. (Madden and others, 1979, fig. 2). The tooth was associated with crocodilian remains belonging to the extinct suborder Mesosuchia (see Langston, Chap. F, this volume). Elsewhere in the Harrat Hadan area, the Umm Himar Formation has yielded sharks (Odontaspis macrota, cf. Scapanorhynchus sp., Ginglymostoma maghrebianum, $G$. blackenhorni, and Squatina sp.); rays (Mylobatidae); bony fishes (Pycnodontiformes, Amiiformes, Siluriformes, and Perciformes); and turtles (Pelomedusidae) (Madden and

${ }^{1}$ U.S. Geological Survey, National Museum of Natural History, Washington, DC 20560 others, Chap. A, this volume). Of the fossil vertebrates, the rays, Crocodilia, and turtles are the most widespread components of the Umm Himar fauna; the single tooth reported here is the only lungfish specimen that was found while collecting at 21 vertebrate-bearing localities in the Umm Himar Formation. At all the localities "fossil bone fragments lie on slopes below-and within-a 2-3-m-thick fossiliferous mudstone" at the base of the Umm Himar Formation (Madden and others, Chap. A, this volume). The mudstone is brown and massive to thick-bedded; its upper part contains abundant root casts up to $3 \mathrm{~cm}$ in diameter. The lower $50 \mathrm{~cm}$ consists of oolitic iron and irregular lumps of bog-iron oxide (Madden and others, Chap. A, this volume).

\section{ACKNOWLEDGMENTS}

Field investigations and subsequent laboratory studies were sponsored by the Directorate General of Mineral Resources (DGMR), Ministry of Petroleum and Mineral Resources, Kingdom of Saudi Arabia, under an agreement with the U.S. Geological Survey (USGS). Participants in the field parties were D.L. Schmidt, C.T. Madden, Ibne Mohammed Naqvi, J.J. Matzko, T.H. Kiilsgaard, Farah Warsama, Mohammed Mellah, and Mohammed Ali.

I thank Robert W. Purdy and Hans-Peter Schultze for reviewing the manuscript, and P.H. Greenwood for furnishing locality data.

The photographs of the lungfish tooth were taken by Robert H. McKinney of the USGS.

\section{DESCRIPTION}

$$
\begin{gathered}
\text { Class Osteichthyes } \\
\text { Subclass Sarcopterygii } \\
\text { Order Dipnoi } \\
\text { Family Ceratodontidae }
\end{gathered}
$$

\footnotetext{
${ }^{2}$ Martin (1984, p. 266) assigns C. humei to the Lepidosirenidae, stating that it is an archaic member of that family.
} 


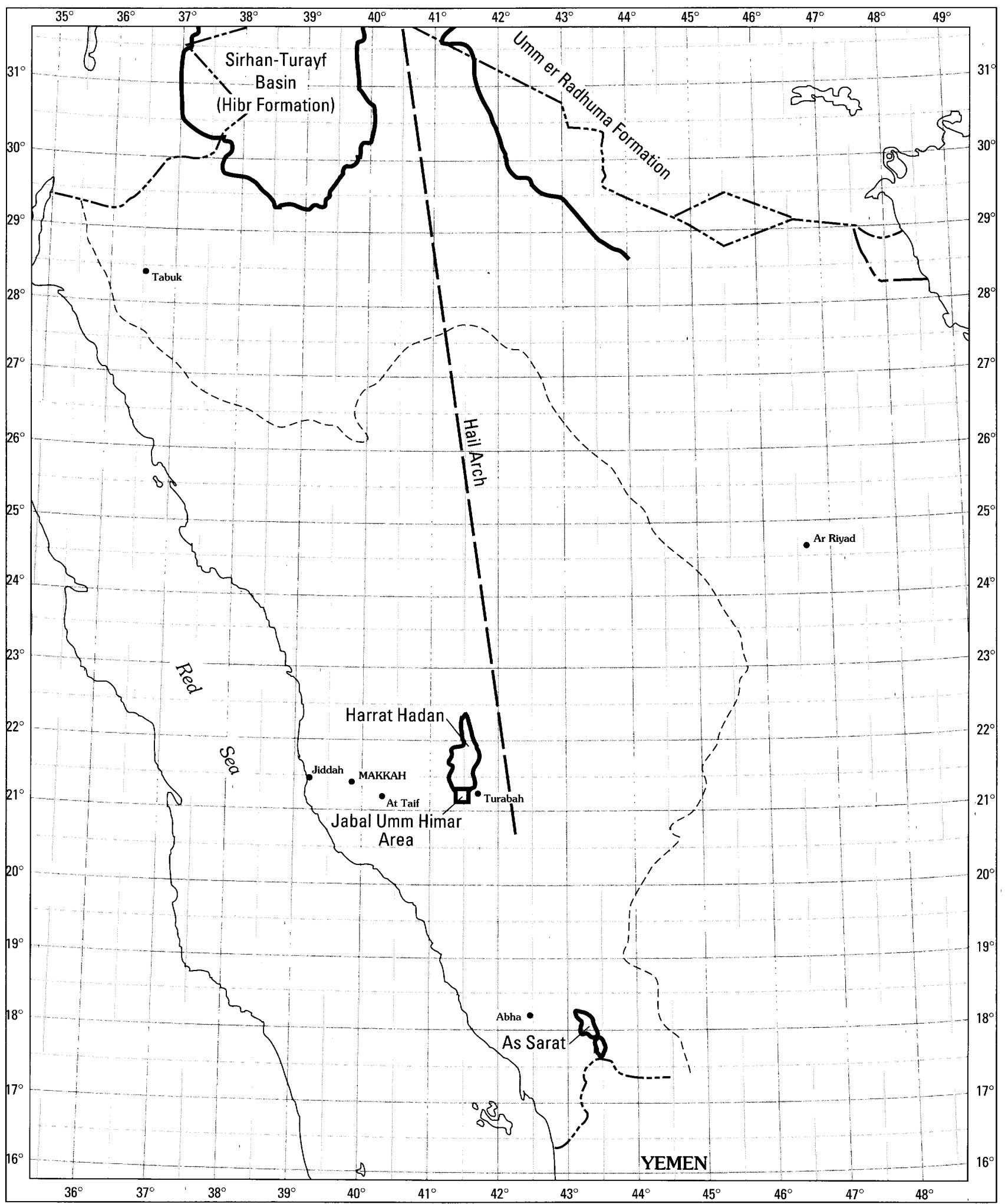

Figure D1. Index map of western Saudi Arabia showing location of the Jabal Umm Himar area relative to the Hail Arch, the SirhanTurayf Basin, and other geologic features. 


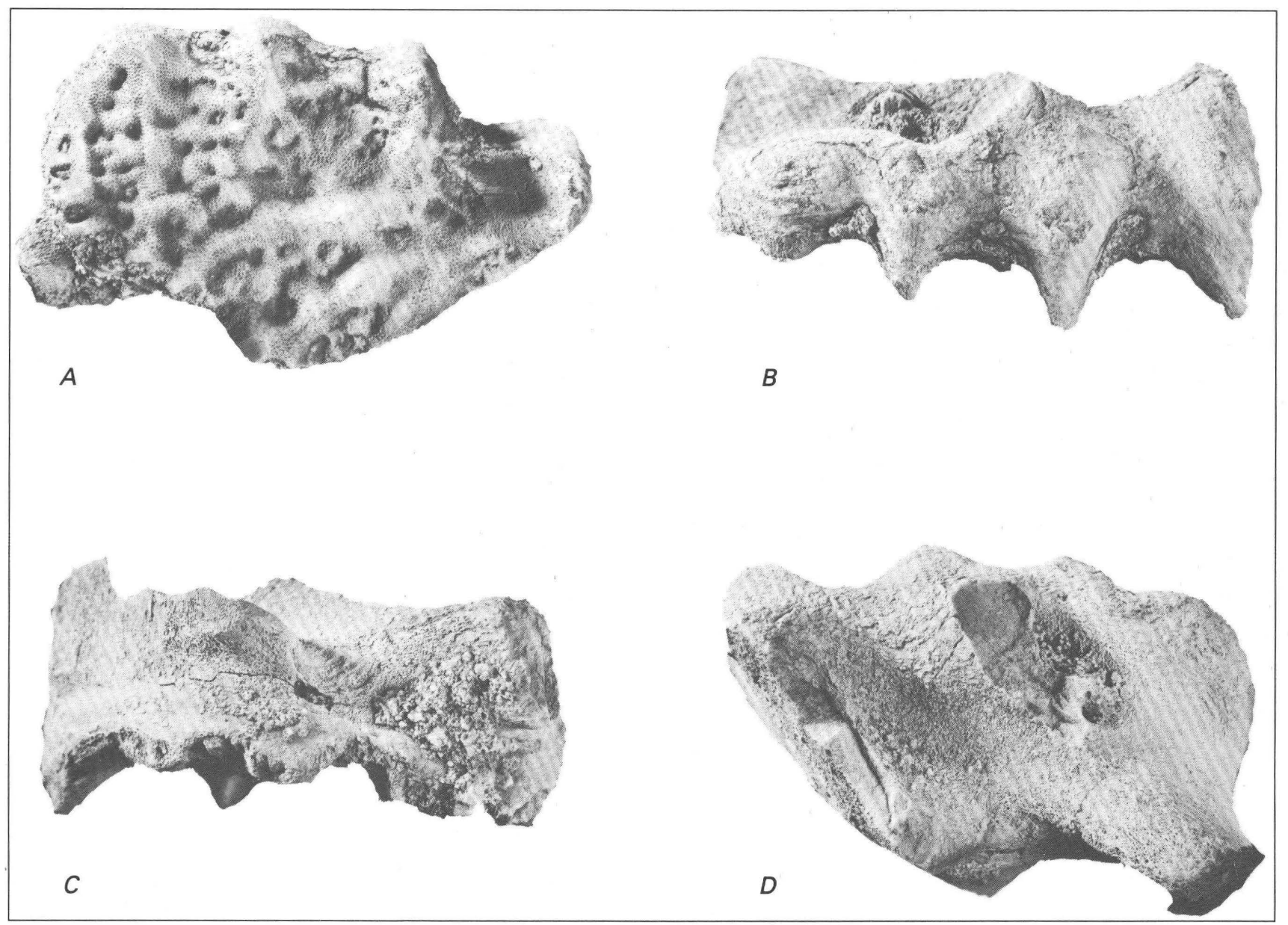

Figure D2. Right pterygo-palatine tooth of Ceratodus humei, USGS SAP 34-LNG-1. A, occlusal view; $B$, external view; $C$, medial view; $D$, dorsal view. $\times 1$.

\section{Ceratodus humei Priem 1914}

Figure D2

A single right pterygo-palatine tooth (USGS SAP 34-LNG-1) of a large lungfish was collected at locality 34 . The occlusal surface (fig. D2A) measures $7.2 .4 \mathrm{~mm}$ anteroposteriorly; its width, from the second crest to the mesialointernal angle, is $46.3 \mathrm{~mm}$. These are the measurements used by Tabaste (1963). The antero-internal border of the tooth, which lies on the midline of the palate, is almost straight for a distance of $45 \mathrm{~mm}$ posterior to the anterior apex of the tooth. The postero-internal border, which is 35 $\mathrm{mm}$ long, is at an angle of 55 degrees to the antero-internal border. The postero-external border, gently curved and 29 $\mathrm{mm}$ long, lies at approximately a right angle to the posterointernal border. The antero-external border is $66 \mathrm{~mm}$ long; it lies approximately parallel to the postero-internal border.

On the antero-external border of the tooth are four crests (figs. D2A, $B$ ). The first three are sharply pointed and prominent; the fourth is much lower and forms the external termination of a low sharp ridge that runs about halfway across the tooth and blends with the reticulate occlusal surface. The height of the crests decreases from front to back. The first and third crests rise prominently above the general occlusal surface and have no medially trending ridges. A low ridge runs posteromedially from the second crest about halfway across the tooth, where it blends with the reticulated occlusal surface.

These characters match the emended diagnosis of the species presented by Tabaste (1963, p. 443; translated from French by F.C.W.): "Masticating surface of the teeth, both upper and lower, almost plane, without crest. Crests reduced to 4 strong denticulations of the labial border. Mesial border rectilinear. Internal border curved." The Saudi Arabian specimen closely resembles one from the Maastrichtian of In Afarag, Algeria, figured by Tabaste (1963, pl. II, fig. 2). It differs from the Algerian specimen in having the mesialointernal angle slightly farther posterior, between the second and third crests. The difference may be due partly to abrasion of the internal border of the Saudi Arabian tooth.

Several wear facets are visible on the crown of the tooth. The largest is on the posterolateral side of the first crest. It measures $16.8 \mathrm{~mm}$ dorsoventrally and $8.6 \mathrm{~mm}$ 
transversely and is so extensive that it may have removed the crown of the crest, altering the outline of the tooth as seen in occlusal view. In other palatine teeth of Ceratodus hume $i$ the first crest curves anterolaterally (compare Arambourg and Joleaud, 1943, pl. III, figs. 7 and 8); this may have been true of the tooth from Saudi Arabia when it was unworn.

There is a small facet, $6.1 \mathrm{~mm}$ anteroposterior and 3.4 $\mathrm{mm}$ wide, on the tip and anterior face of the fourth crest. No wear facets are visible on the second and third crests. A single facet runs along almost the entire width of the posterior edge of the tooth crown. It begins at the lateral edge of the crown and extends medially for $23 \mathrm{~mm}$. Its maximum anteroposterior width is $5.8 \mathrm{~mm}$. There is a round facet, 3.5 $\mathrm{mm}$ in diameter, at the posterior end of the anterointernal border. It is at the posterior end of an indistinct discontinuous ridge that runs posteriorly from the first crest.

The tooth plate is attached dorsally to the heavy pterygoid bone (figs. D2C, D), which has a maximum dorsoventral thickness of $20.7 \mathrm{~mm}$ at the midline of the skull, over the anterior end of the tooth (fig. D2C). The ascending process of the pterygoid projects posterolaterally above the tooth plate, at an angle of 25 degrees with the midline of the skull. Its origin lies above the area between the third and fourth crests of the tooth plate. The process, which is broken, projects posterodorsally to the posterior edge of the tooth plate. At its broken (posterior) end, the process is 19.2 $\mathrm{mm}$ high and $10.1 \mathrm{~mm}$ wide.

Above the tooth plate the pterygoid surface is dorsally concave, having a deep anteroposterior trough medial to the origin of the ascending process (fig. D2D).

\section{COMPARISON WITH OTHER AFRICAN SPECIES OF CERATODUS}

Ceratodus is a form genus for Mesozoic and Tertiary dipnoan tooth plates; skull roofs of Mesozoic lungfishes with ceratodontid tooth plates are so distinct from each other that they have been assigned to at least four different genera (Schultze, 1981, p. 188). Nevertheless, given the limitations of available material, it appears that specific distinctions within the form genus are valid and useful (see also Schultze, 1981).

The type specimen of $C$. humei is $34 \mathrm{~mm}$ long and 20 mm wide, much smaller than the Saudi Arabian specimen discussed there. Authors after Priem (1914) have assigned much larger teeth to the species: Stromer and Weiler (1930) report a mandibular tooth $53 \mathrm{~mm}$ long and $29 \mathrm{~mm}$ wide at the second crest; Arambourg and Joleaud (1943) state that the largest tooth in their collection is $60 \mathrm{~mm}$ long and 50 $\mathrm{mm}$ wide, with the largest mandibular tooth being $45 \mathrm{~mm}$ long and $35 \mathrm{~mm}$ wide; Tabaste (1963) reports the largest tooth from her Paleocene collection as being $94 \mathrm{~mm}$ long.
On the occlusal surface of the tooth plate of Ceratodus hume $i$ the crests are not produced medially as well-defined ridges. This is in contrast to the pterygo-palatine teeth of other African species of Ceratodus: Ceratodus africanus Haug 1905 (Peyer, 1925, pl. 1 and 2; Arambourg and Joleaud, 1943, pl. 2 and 3; Tabaste, 1963, pl. 1); C. tuberculatus Tabaste 1963 (pl. 2 and 3); C. tiguidiensis Tabaste 1963 (pl. 5); C. pectinatus Tabaste 1963 (pl. 6); and C. protopteroides Tabaste 1963 (pl. 6).

In Ceratodus africanus, the tooth crests are directed posteriorly beginning with the third crest (Tabaste, 1963, p. 442). In the Saudi Arabian specimen, all four crests are directed anteriorly, the angle with the sagittal plane increasing from the first crest (parallel to the plane) to the fourth (almost at right angles to it).

In the Saudi Arabian specimen, the ascending process of the pterygoid originates above the area between the second and third crests; in C. africanus, it originates between the third and fourth crests (Peyer, 1925, p. 5).

\section{GEOGRAPHIC DISTRIBUTION AND STRATIGRAPHIC RANGE OF CERATODUS HUMEI}

Ceratodus humei has been reported from the Lower Cretaceous of the Djoua Depression on the northeast border of the Hoggar, Algeria; southern Morocco; and in Niger (Tabaste, 1963, p. 439, 443). Martin (1981, p. 73) identified as Ceratodus humei a tooth plate from the lower Cenomanian of Baharija, Upper Egypt, which was referred to $C$. africanus by Peyer (1925). The species is known from the Campanian (upper Senonian) of Quft, Upper Egypt (Priem, 1914, p. 368); of Mahamid, Upper Egypt (Stromer and Weiler, 1930, p. 25; Arambourg and Joleaud, 1943, p. 47); and of Damergou, Niger (Arambourg and Joleaud, 1943, p. 47). Greigert and others (1954) placed the Damergou material in the Turonian. Maastrichtian occurrences are at In Afarag, Algeria, and at Mt. Igadman and Termeuth, Niger (Tabaste, 1963, p. 439-440).

Tabaste (1963, p. 444) first reported Ceratodus from the Tertiary outside Australia. She (1963, table IV) listed $C$. humei from the Paleocene at Cheik Keini and In Fargas, Mali. Martin (1984, p. 268) states that C. humei or a closely related species persists into the Lutetian (middle Eocene) at Tamaguilelt in east central Mali. Savage (1969, p. 169) reported Ceratodus sp. indet. from beds of probable late Eocene age at Dor el Taha in southern Libya.

The presence of Ceratodus humei in Saudi Arabia is the easternmost occurrence in the geographical range for the species that covers almost the entire width of North Africa. Its range in Paleocene time, from the eastern Mali to Saudi Arabia, almost equals the maximum extent of the species. The geologic range of $C$. humei sensu stricto was from Lower Cretaceous into Paleocene. 


\section{PALEOECOLOGY}

Tabaste (1963, p. 458) reports that, according to A.F. de Lapparent, lungfish teeth are found in large concentrations at widely scattered points in the Sahara. Tabaste interprets these concentrations as perhaps traces of temporary lakes where lungfish could survive droughts because of their ability to aestivate.

In contrast to the large numbers of teeth found at Saharan localities, the presence of only one lungfish tooth in the collections from Jabal Umm Himar suggests that the specimen was transported to its place of burial. Its association with crocodilians, in a fauna that also includes sharks, rays, bony fishes and turtles, is best explained by interpreting the fauna as estuarine or lagoonal, having lived near the mouths of streams in whose drainage system the lungfish lived.

The presence of iron oolites and root casts in the fossilbearing horizon suggests deposition in an estuarine or lagoonal marsh (see Madden and others, Chap. A, this volume).

\section{REFERENCES}

Arambourg, Camille, and Joleaud, L., 1943, Vertébré fossiles du Bassin du Niger: West French Africa, Direction des Mines, Bulletin 7, p. 33-70.

Greigert, J., Joulia, F., and de Lapparent, A.F., 1954, Repartition stratigraphique des gisements de Vertébrés dans le Crétacé du Niger: Comptes Rendus de l'Académie des Sciences, Paris, v. 239, p. 433-439.

Hauf, Émile, 1905, Paléontologie. Documents scientifiques de la Mission saharienne (Mission Fureau-Lamy). Publication de la Société de Géographie, Paris, p. 751-832.
Madden, C.T., Naqvi, I.M., Whitmore, F.C., Jr., Schmidt, D.L., Langston, Wann, Jr., and Wood, R.C., 1979, Paleocene vertebrates from coastal deposits in the Harrat Hadan area, At Taif region, Kingdom of Saudi Arabia: U.S. Geological Survey Saudi Arabian Project Report 269, 29 p.

Martin, Michel, 1981, Über drei Zahnplatten von Ceratodus aus der Ägyptischen Kreide: Mitteilungen der Bayerischen Staatssammlung für Paläontologie und historische Geologie, Heft 21, p. 73-80.

1984, Deux Lepidosirenidae (Dipnoi) Crétacés du Sahara, Protopterus humei (Priem) et Protopterus protopteroides (Tabaste): Paläontologische Zeitschrift, Bd. 58, Heft 3/4, p. 265-277.

Peyer, B., 1925, Ergebnisse der Forschungsreisen Prof. E. Stromers in den Wüstem Ägyptens. II. Wirbeltier-Reste der Baharije-Stufe (unterstes Cenoman). 6. Die CeratodusFunde: Abhandlungen der Bayerischen Akademie der Wissenschaften, Band 30, Abhandlung 5, 23 p.

Priem, M.F., 1914, Sur les vertébrés du Crétacé et de l'Éocène d'Égypte: Société Géologique de France Bulletin, v. 14, p. 366-382.

Savage, R.J.G., 1969, Early Tertiary mammal locality in southern Libya: Proceedings of the Geological Society of London, no. 1657, p. 167-171.

Schultze, Hans-Peter, 1981, A dipnoan tooth plate from the Lower Cretaceous of Kansas, USA: Transactions of the Kansas Academy of Sciences, v. 84, no. 3, p. 187-195.

Stromer, E., and Weiler, W., 1930, Ergebnisse der Forschungsreisen Prof. E. Stromers in den Wüstem Ägyptens. VI. Beschreibung von Wirbeltier-Resten aus dem nubischen Sandsteine Ober-ägyptens und aus ägyptischen Phosphaten nebst Bemerkungen über die Geologie der Umgegend von Mahamid in Ober-ägypten: Abhandlungen der Bayerischen Akademie der Wissenschaften, MathematisheNaturwissenschaftliche Abteilung, Neue Folge 7, p. 1-42.

Tabaste, Nicole, 1963, Étude des restes de poissons du Crétacé saharienne: Institut français d'Afrique noire Mémoires, v. 68 , p. $436-499$. 


\section{Paleocene Pelomedusid Turtles from Jabal Umm Himar, Kingdom of Saudi Arabia}

By Roger C. Wood

PALEOCENE VERTEBRATES FROM JABAL UMM HIMAR, KINGDOM OF SAUDI ARABIA

U.S. GEOLOGICAL SURVEY BULLETIN 2093-E

Prepared in cooperation with the Ministry of

Petroleum and Mineral Resources, Jiddah,

Kingdom of Saudi Arabia

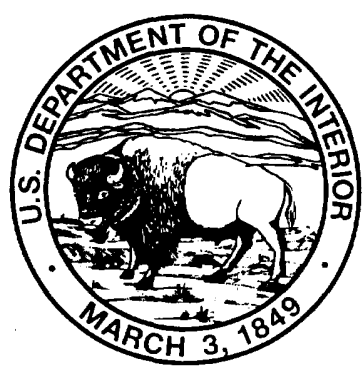

UNITED STATES GOVERNMENT PRINTING OFFICE, WASHINGTON : 1995 


\section{CONTENTS}

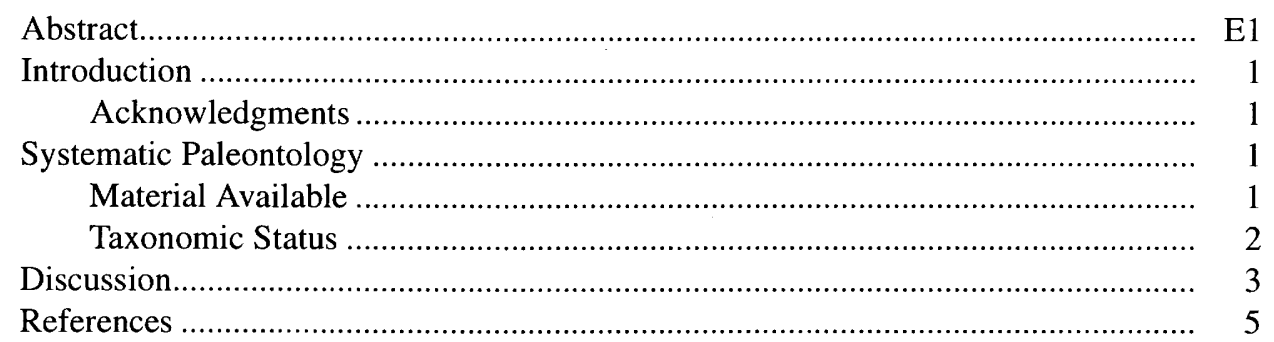

\section{FIGURES}

E1. Posterior half, anterior half, and composite drawings of xiphiplastron …….................................................... E2

E2. Ventral and dorsal view of proximal end of pelomedusid humerus ................................................................. 2

E3. Dorsal and posterior views of isolated neural bones of Arabian pelomedusid .................................................. 3 


\title{
Paleocene Pelomedusid Turtles from Jabal Umm Himar, Kingdom of Saudi Arabia
}

\author{
By Roger C. Wood ${ }^{1}$
}

\begin{abstract}
Fragmentary chelonian remains collected from Jabal Umm Himar, near Turabah, Saudi Arabia, appear to represent a single type of pelomedusid (side-necked) turtle. Too little of this taxon has been preserved to permit diagnosis below the familial level. However, it was clearly a large species and almost certainly primarily aquatic. This occurrence is the first record of pelomedusid turtles, either living or fossil, from the Arabian Peninsula. Comparison with both African and Asiatic fossil pelomedusids provides no definite insights regarding the Arabian turtle's relationships to other members of the family from either continent.
\end{abstract}

\section{INTRODUCTION}

Fossil turtle remains are relatively common among the Paleocene fossil vertebrates collected from 21 localities at Jabal Umm Himar, near Turabah, in the Harrat Hadan area, At Taif region, Kingdom of Saudi Arabia (Madden and others, 1979). Despite their fragmentary nature, these remains are of particular interest because they provide the first adequate documentation for the presence of this reptilian order from the Arabian Peninsula. These specimens form the basis for the description in the present report.

\section{ACKNOWLEDGMENTS}

I am grateful to C.T. Madden and F.C. Whitmore, Jr., for their invitation to study this material. I thank L. Cahen and A.J. Charig for permission to examine African fossil turtles in their care from Zaire and Nigeria, respectively. Thanks are also due to C.T. Madden and C.A. Walker for unpublished information. The line illustrations were drawn by Laszlo Meszoly. Funding for the line drawings was provided by a grant from Stockton State College's Research and Professional Development Committee. A postdoctoral

${ }^{1}$ Faculty of Science and Mathematics, Stockton State College, Pomona, N.J. 08240. fellowship from the National Science Foundation provided the time necessary to complete my research, while a grant from the National Geographic Society made it possible for me to examine comparative material in several European museums during the summer of 1978.

The pelomedusid turtle fossils were collected during field investigations sponsored by the Directorate General of Mineral Resources (DGMR), Kingdom of Saudi Arabia under an agreement with the U.S. Geological Survey (USGS).

C.T. Madden and F.C. Whitmore, Jr., edited and reviewed the original manuscript.

\section{SYSTEMATIC PALEONTOLOGY}

\author{
Order Testudines \\ Suborder Pleurodira \\ Family Pelomedusidae
}

MATERIAL AVAILABLE

Turtle remains are known from 15 of the 21 localities (Madden and others, 1979). Most of these are amorphous shell fragments of no taxonomic value. Nevertheless, their abundance suggests that turtles must have been a relatively common component of the Umm Himar local fauna.

A partial shell was found at locality 33 , but it was severely eroded, badly fractured, and collected as unassociated pieces rather than in a plaster jacket. Efforts to reassemble these fragments proved unsuccessful; however, given the shell's wretched state of preservation, it seems unlikely that much in the way of useful taxonomic information would have been discernible in any event.

Only seven localities $(3,4,28,29,33,35$, and 38) yielded identifiable material, all isolated specimens. Anatomically recognizable bones of the shell include several neurals and a few peripherals from the carapace as well as a nearly complete right hypoplastron and three partial xiphiplastra from the plastron. The remainder of the skeleton is represented only by the proximal end of a humerus and several pelvic fragments. 


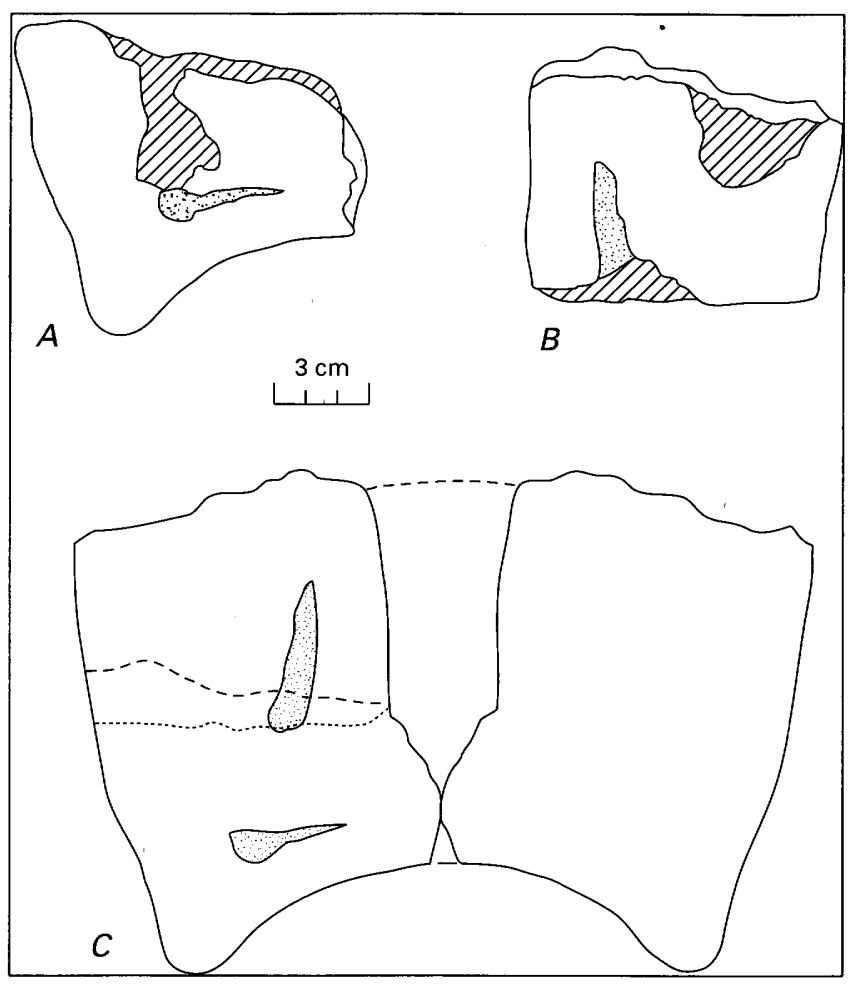

Figure E1. $A$, Posterior half of left xiphiplastron (USGS SAP NO-Pel-1); $B$, anterior half of right xiphiplastron (USGS SAP 38-Pel-1); $C$, composite drawing of left and right xiphiplastron based upon specimens shown in $A$ and $B$, with the latter projected in mirror image. The internal surface is shown on the left, the external surface on the right. Stippled areas represent pelvic scars, diagonally shaded areas are broken surfaces. The dashed line in $C$ marks the anterior border of specimen $A$; the dotted line marks the posterior border of specimen $B$.

\section{TAXONOMIC STATUS}

The available evidence indicates that only a single type of chelonian is represented in the Umm Himar local fauna. The species represented appears to have been a pelomedusid or side-necked turtle. This identification is based upon the following typical characters: (1) presence of a laterally placed, subcircular mesoplastron on the underside (plastron) of the shell; (2) fusion of the pelvic girdle to the shell (fig. E1); (3) proportions of the head of the humerus (fig. E2); and (4) the shape and presumed arrangement of the neural bones (fig. E3) along the midline of the top part of the shell (carapace).

Of these four characters, the last is the most tenuous and requires some clarification. In typical pelomedusids, the first neural abuts directly against the rear of the nuchal bone and is relatively long and narrow, forming an elongate oval. The successive neurals are all hexagonal (often appropriately described as coffin shaped) and follow in uninterrupted sequence, their proportions toward the rear of the series becoming increasingly short anteroposteriorly and

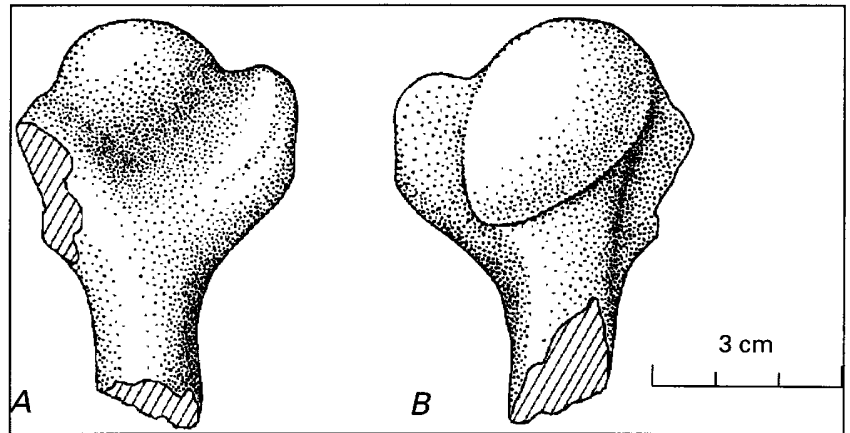

Figure E2. Proximal end of pelomedusid humerus (USGS SAP 3-Pel-1), in $A$, ventral and $B$, dorsal views. Diagonally shaded areas are broken bone surfaces.

broad transversely. Pelomedusids usually have six to seven neurals.

One of the identifiable Umm Himar shell fragments is clearly a first neural (fig. E3A). Because they are both hexagonal in outline and relatively elongate anteroposteriorly, several other isolated neural specimens (figs. $\mathrm{E} 3 B, C, D$ ) undoubtedly were situated close to or immediately behind the first one. Although the total number of neurals in a typical Umm Himar shell cannot be determined from present evidence, what has been preserved accords well with the widely prevalent pelomedusid pattern and suggests that the Arabian form's shell probably was characterized by six to seven neurals arranged along the midline of the carapace in unbroken sequence.

Despite the fragmentary and disarticulated nature of the material, several features can be discerned that might be of taxonomic value below the familial level. For example, cross-sectional views of the neural bones (figs. E $3 F, G, H$ ) indicate that a rather pronounced ridge extending along much of the length of the carapace's midline. This ridge, or keel, was apparently continuous and characterized by gently sloping sides in contrast, for instance, to the abruptly projecting and discontinuous keels of some turtles, perhaps best exemplified by certain populations of the living North American emydines Graptemys and Malaclemys.

Even discounting the presence of the median ridge on the external surface of the neurals, these bones appear to be disproportionately thick in relation to their surface areas (see especially fig. E3H). Because bones in turtles do not apparently become progressively thicker as shell size increases, the massiveness of the Arabian neurals cannot legitimately be ascribed simply to their large size. Therefore, the thickness of this turtle's bones might, as part of a suite of characters, perhaps be perceived as a distinctive feature of taxonomic value.

While size alone is insufficient for diagnosing any turtle species, it might (again, with other characters) contribute to such a diagnosis. Adult specimens of the Arabian pelomedusid clearly attained a rather large size, their shells being 


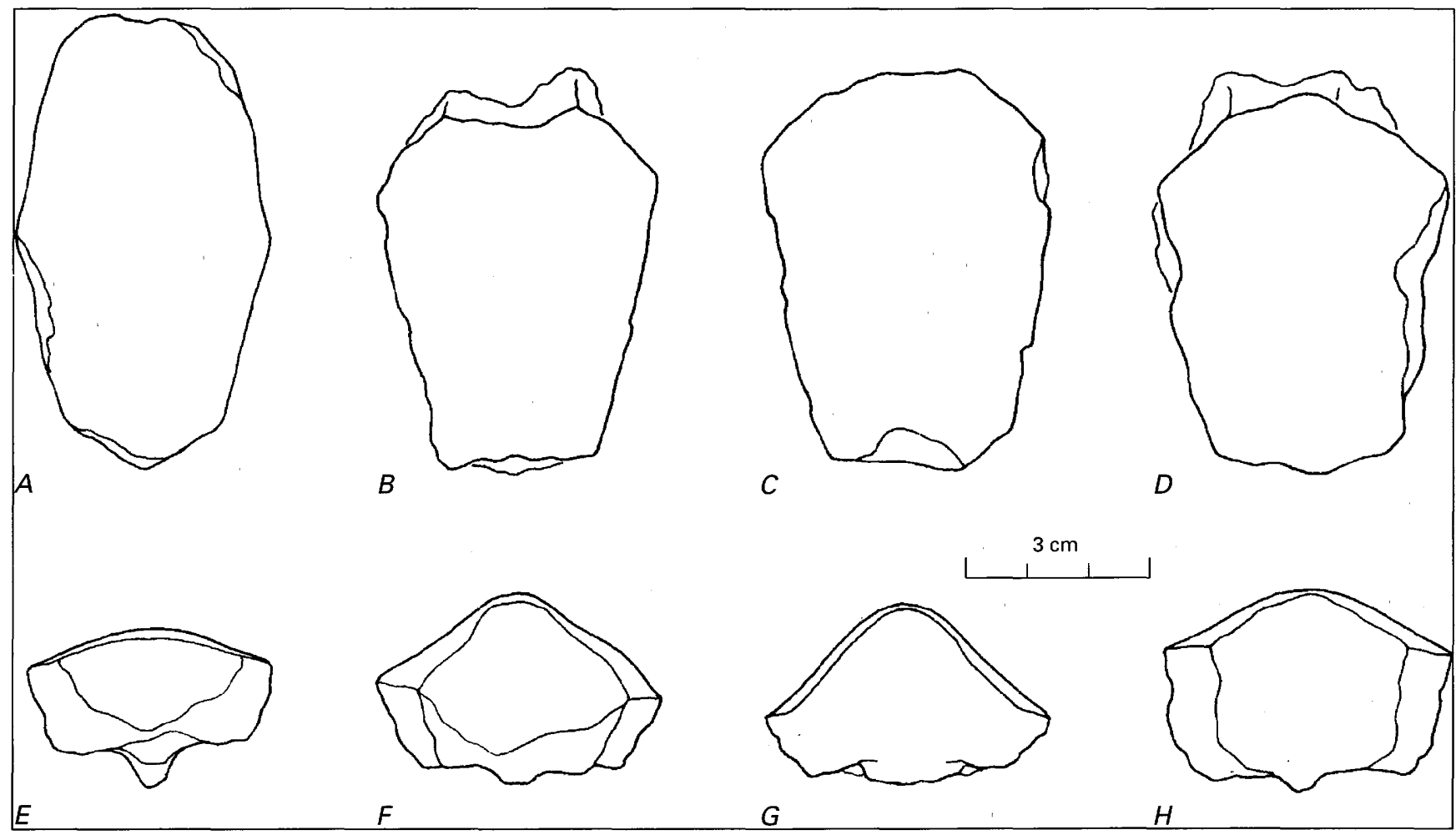

Figure E3. Isolated neural bones of Arabian pelomedusid (USGS SAP 33r-Pel-1, USGS SAP 33-Pel-2, USGS SAP 33r-Pel- 3, USGS SAP 29-Pel-1): $A-D$, dorsal views, anterior ends facing top of page; $E-H$, views of posterior ends showing thickness and median ridge. $A$ is a first neural, the others are probably second or third neurals.

roughly comparable in length to those of the largest living pelomedusid, Podocnemis expansa from the Amazon and Orinoco River basins of South America. The badly fragmented shell from locality 33 measured roughly $90 \mathrm{~cm}$ in length (C.T. Madden, personal commun., 1978). The largest known shells of $P$. expansa are reported to attain a length of $87.5 \mathrm{~cm}$ (Pritchard, 1979, p. 751). A few other fossil pelomedusids were comparable in size to the Arabian form ("Podocnemis" indica Lydekker, 1887) or even larger (Stupendemys geographicus Wood, 1976).

Several other features can be discerned that, however, are unlikely to be taxonomically useful. The external shell surfaces are covered with a lightly inscribed network of anastomosing vermiculations. This sculpture is typical of many, but by no means all, pelomedusids. 'Moreover, judging from a single specimen composed of an associated hexagonal neural and the medial portion of an adjacent peripheral, shells of the Arabian pelomedusid appear to have been moderately flattened dorsoventrally, suggesting that this was a highly aquatic species. Finally, the shape of the anal notch at the posterior end of the plastron seems to have been somewhat variable. In at least some extant species of pelomedusids (Podocnemis unifilis), anal notch shape varies considerably and is not apparently correlated with either sex or size.
In summary, it is possible that the Umm Himar pelomedusid may represent a previously undescribed taxon characterized by rather large size, very thickly boned shell, and a continuous keel along the midline of the carapace (rather than the usually flat transverse arch). However, the available material does not really permit a definitive diagnosis. For the present, therefore, the Uinm Himar chelonian is best simply named "Pelomedusidae gen. et sp. ident."

\section{DISCUSSION}

This section describes the first record of pelomedusid turtles, either fossil or living, from the Arabian Peninsula. The occurrence is not particularly surprising, however. Fossil pelomedusids are known from both east and west of the Arabian locality. In Africa, they are relatively abundant (Wood, 1971), whereas in the Indian subcontinent they are known so far from only a few specimens (Wood, 1970). The most similar of the asiatic fossil pelomedusids appears to be "Podocnemis" indica (Lydekker,' 1887) from the Paleocene or Eocene of Pakistan. It is likely that this taxon represents a pelomedusid; although this unfortunately cannot be conclusively shown. Its carapace is large (nearly $90 \mathrm{~cm}$ long), the neural pattern is similar (although nothing is known about 
the relative thickness of the neurals), and, like the Arabian shell material ". . . the median line is much elevated, with the [pleurals] sloping rapidly away on either side" (Lydekker, 1887, p. 64). The sediments from which " $P$. indica" was recovered were described as ". . . either of marine or estuarine origin [which] is confirmed by the Chelonians, one of which is covered with the 'spat' of oysters while sharks' teeth are embedded in the matrix of the other" (Lydekker, 1887, p. 59-60).

In Africa, the geographically closest fossil pelomedusid is Podocnemis somaliensis from the middle Eocene of Somalia (Walker, 1966). A variety of morphological details militates against any particularly close relationship between the Somalian and Arabian pelomedusids. Abundant nautiloids were collected along with the single known shell of $P$. somaliensis, which suggests that this fossil pelomedusid, like " $P$." indica, may have been salt tolerant.

Shweboemys antiqua (Andrews) from upper Eocene deltaic or nearshore marine deposits of northern Egypt is in some respects similar to the Arabian turtle. Although smaller, its carapace had a similar neural bone pattern and its pleurals slope flatly to either side of a midline peak. Its neurals, however, are not disproportionately thick.

Fragments from Sokoto Province, Nigeria, originally described by Swinton (1930) as "Podocnemis-like," almost certainly represent a very large pelomedusid and are roughly contemporaneous with the Arabian material. Several isolated neural bones (R5661, R5665, R5685) examined in the paleontological collections of the British Museum (Natural History) are roughly comparable in size and shape to the hexagonal Umm Himar neurals, but they are proportionately much thinner and lack any signs of a midline ridge. Swinton also described and figured (Swinton, 1930, pl. 14, fig. 2) the ventral surface of a first neural bone and said that its dorsal surface is ". . . devoid of ornamentation." Complete shells and even skulls of very large pelomedusids recently have been discovered in northern Nigeria (C.A. Walker, personal commun., 1980); this discovery should soon permit a very full characterization of this taxon. Only when similar good fortune results in the recovery of comparably preserved specimens from the Arabian Peninsula will adequate comparisons be possible.

Of all the African fossil pelomedusids, the most similar to the Arabian turtle in terms of both age and morphology appears to be Taphrosphys congolensis (Wood, 1975). Remains referable to this species range in age from Late Cretaceous through Eocene, but the best preserved and most abundant specimens are Paleocene in age. Undescribed material now under study permits fairly complete reconstruction of the entire carapace of $T$. congolensis. It was rather large (perhaps $80 \mathrm{~cm}$ in length) and had seven neurals shaped and arranged according to the typical pelomedusid pattern. Rather deeply inscribed anastomosing vermiculations covered its external surface. Conceivably there may have been a continuous ridge along the midline of the carapace, but this possibility cannot be verified from those portions of the carapace that have been preserved, nearly all of which have been squashed flat; in some cases, the dorsal surface of the carapace is actually somewhat concave. Unlike the Arabian pelomedusid shell with its markedly thickened bone, however, the shell of $T$. congolensis tends to be thinner than one might ordinarily expect for a turtle of its size.

Given the similarities between the Umm Himar pelomedusid and $T$. congolensis, it is tempting to speculate, despite their geographic separation, that they might be particularly closely related to each other. Again, however, until such time as better preserved specimens of the Arabian turtle become known, such speculations cannot be confirmed.

One nonanatomical commonality worth noting concerns habitat. The environment represented by the deposits in which the Umm Himar fauna occurs was estuarine or lagoonal (Madden and others, 1979; and Chap. A, this volume). Likewise, the sediments from which $T$. congolensis was recovered also accumulated in a littoral marine environment (Cahen, 1954). Although pelomedusids are all freshwater forms at present, the family's fossil record indicates that they were not always so narrowly adapted in the past. Two tortoiselike and therefore presumably terrestrial forms (both from the middle Tertiary of Africa and neither yet reported formally in the published literature) have been recognized. More directly relevant to interpretation of the turtles from Jabal Umm Himar are a variety of other fossil pelomedusids (especially of Late Cretaceous and early Tertiary age) that seem to have inhabited brackish and perhaps even marine waters. The nearshore or deltaic marine habitat apparently common to both $T$. congolensis and the Umm Himar pelomedusid raises the possibility that uninterrupted gene flow may have been possible between these two contemporaneous forms on opposite sides of the African continent through intermediate populations around its periphery. Such distributional continuity as postulated here would in turn help to account for the morphological similarities noted above.

Why some fossil turtles had exceptionally thick shells is not at all understood nor has the question received much attention. Some authors (Fichter, 1969; Jackson, 1978) have suggested, without either much conviction or enthusiasm, that the thicker shells of some North American fossil turtles may be correlated with cooler climates. Such an explanation would seem to have little, if any, relevance to the Arabian turtles, which are believed to have lived in a tropical or subtropical climate (Madden and others, 1979; and Chap. A, this volume). Convincing evidence, however, cannot at present be readily marshalled in support of some alternative explanation. The problem, therefore, remains unsolved. 


\section{REFERENCES}

Cahen, L., 1954, Géologie du Congo Belge: Liège, Imprimerie $H$ Vaillant-Carmanne, $577 \mathrm{p}$.

Fichter, L.S., 1969, Geographical distribution and osteological variation in fossil and recent specimens of two species of Kinosternon (Testúdines): Journal of Herpetology, v. 3, nos. 3-4, p. 113-119.

Jackson, D.R., 1978, Evolution and fossil record of the chicken turtle Deirochelys, with a re-evaluation of the genus: Tulane Studies in Zoology and Botany, v. 20, nos. 1-2, p. 35-55.

Lydekker, R., 1887, Eocene chelonians from the Salt-Range: Memoirs of the Geological Survey of India, Paleontologia Indica, Series 10: Indian Tertiary and Post-Tertiary Vertebrata, v. 4, pt. 3, p. 59-65.

Madden, C.T., Naqvi, I.M., Whitmore, F.C., Jr., Schmidt, D.L., Langston, Wann, Jr., and Wood, R.C., 1979, Paleocene vertebrates from coastal deposits in the Harrat Hadan area, At Taif region, Kingdom of Saudi Arabia: U.S. Geological Survey Saudi Arabian Project Report 269, 29 p.

Pritchard, P.C.H., 1979, Encyclopedia of turtles: Neptune, N.J., T.F.H. Publications, 895 p.

Swinton, W.E., 1930, On fossil Reptilia from Sokoto Province: Geological Survey of Nigeria, Bulletin no. 13, p. 15-60.

Walker, C.A., 1966, Podocnemis somaliensis, a new pleurodiran turtle from the middle Eocene of Somalia: Palaeontology, v. 9, pt. 3, p. 511-516.

Wood, R.C., 1970, A review of the fossil Pelomedusidae (Testudines, Pleurodira) of Asia: Breviora, no. 357, p. 1-24.

1971, The fossil Pelomedusidae (Testudines, Pleurodira) of Africa: Ph.D. thesis, Harvard University.

1975, Redescription of "Bantuchelys" congolensis, a fossil pelomedusid turtle from the Paleocene of Africa: Revue de Zoologie Africaine, v. 89, fasc. 1, p. 127-144.

1976, Stupendemys geographicus, the world's largest turtle: Breviora, no. 436, p. 1-31. 


\section{Dyrosaurs (Crocodilia, Mesosuchia) from the Paleocene Umm Himar Formation, Kingdom of Saudi Arabia}

By Wann Langston, Jr.

PALEOCENE VERTEBRATES FROM JABAL UMM HIMAR, KINGDOM OF SAUDI ARABIA

U.S. GEOLOGICAL SURVEY BULLETIN 2093-F

Prepared in cooperation with the Ministry of Petroleum and Mineral Resources, Jiddah, Kingdom of Saudi Arabia

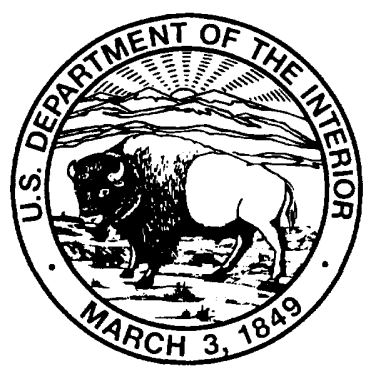




\section{CONTENTS}

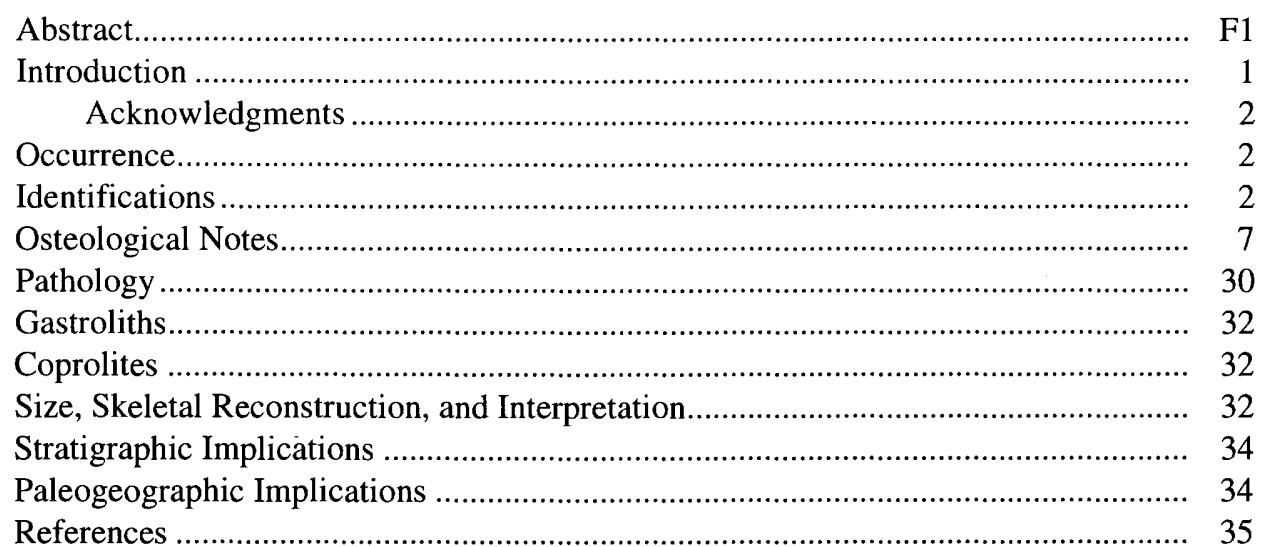

\section{FIGURES}

F1. Geologic map of Jabal Umm Himar area, showing fossil localities ........................................................... F3

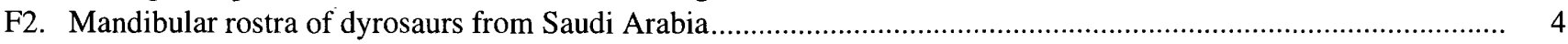

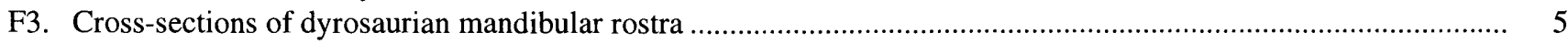

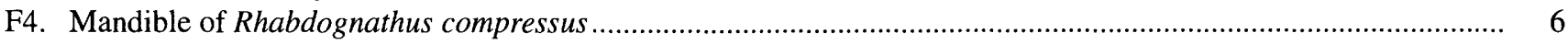

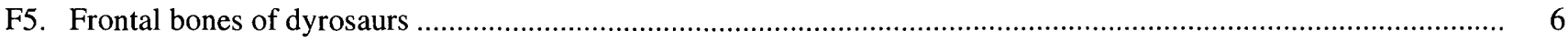

F6. Rhabdognathus sp., no. 35-CR-9. End of interlocked cranial and mandibular rostra.......................................... 8

F7. Rhabdognathus sp. Reconstruction of post-rostral skull, from above .............................................................. 8

F8. Rhabdognathus sp. Quadrate bones from above ......................................................................................

F9. Rhabdognathus sp., no. 37A-CR-1. Distal (articular) end of left quadrate ....................................................... 9

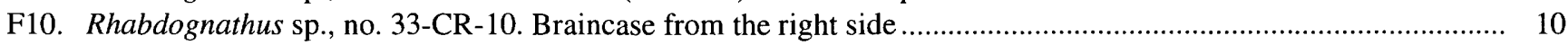

F11. Rhabdognathus sp., no. 37-CR-1. Articular region of left mandible, from above ............................................. 11

F12. Rhabdognathus sp., no. 37-CR-1. First and second mandibular teeth showing recumbency and overlapping roots

F13. Rhabdognathus sp. no. 37-CR-1. Atlas and axis, right lateral view

F14. Rhabdognathus sp., no. 57-CR-1. Opposing articular ends of the atlantal and axial centra .................................. 13

F15. Rhabdognathus sp. Variation in the ventral ridge system on axial vertebrae................................................. 14

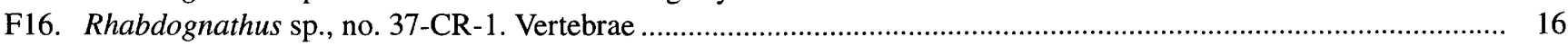

F17. Rhabdognathus sp., no. 37-CR-1. Articulated seventh cervical to ninth thoracic vertebrae, ventral aspect ............ 16

F18. Rhabdognathus sp., no. 37-CR-1. Caudal vertebrae ............................................................................... 18

F19. Rhabdognathus sp., no. 37-CR-1. Proximal ends of thoracic ribs ................................................................ 19

F20. Rhabdognathus sp., no. 37-CR-1. Sacral vertebrae and ribs, dorsal aspect ..................................................... 19

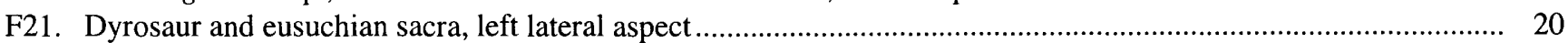

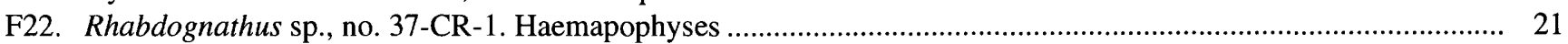

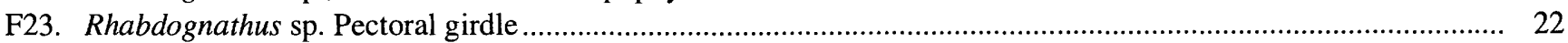

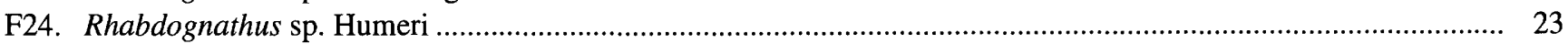

F25. Rhabdognathus sp. Articular ends of the humerus of large individuals ........................................................ 23

F26. Rhabdognathus sp., no. 58-CR-1. Right pubis, ventral aspect.................................................................... 24

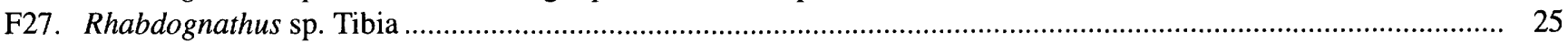

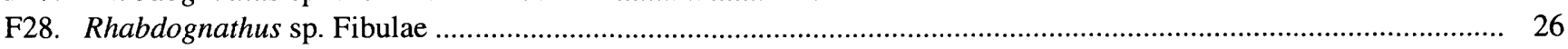

F29. Rhabdognathus sp. Reconstruction of right pes ...................................................................................... 27 
F30. Rhabdognathus sp., no. 37-CR-2. Left astragalus and calcaneum .............................................................. F28

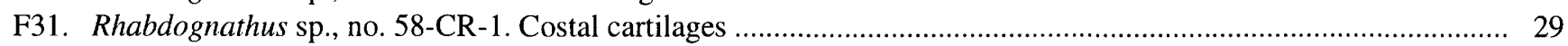

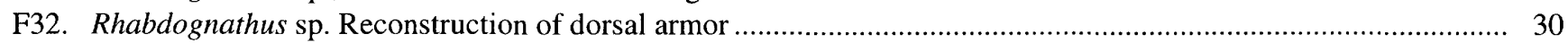

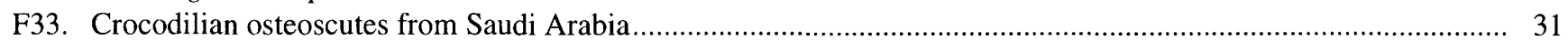

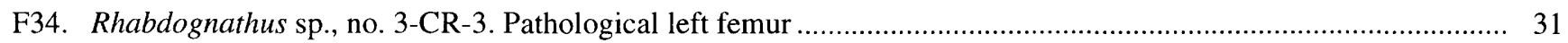

F35. Hyposaurine dyrosaur skeleton based primarily on Rhabdognathus sp. from Saudi Arabia ............................... 33

\section{TABLES}

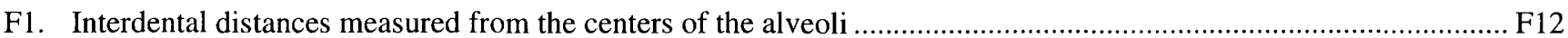

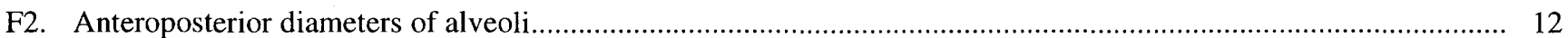

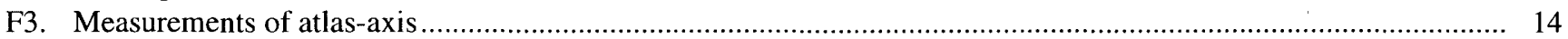

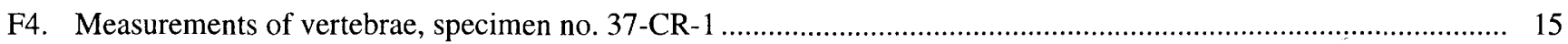

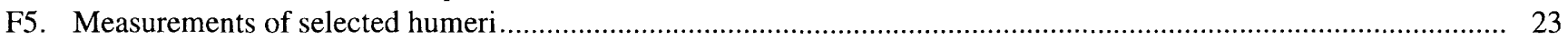

F6. Comparative measurements of dyrosaurian femora................................................................................. 25

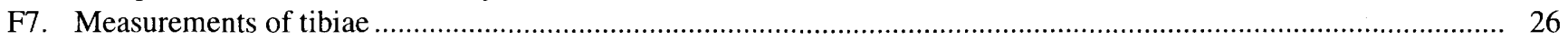





\title{
Dyrosaurs (Crocodilia, Mesosuchia) from the Paleocene Umm Himar Formation, Kingdom of Saudi Arabia
}

\author{
By Wann Langston, Jr. ${ }^{1}$
}

\begin{abstract}
Dyrosaur remains from western Saudi Arabia support the view that sediments of the Umm Himar Formation are of Paleocene age and represent lagoonal and estuarine environments. Bones and teeth of at least 45 individuals, from 15 localities, vary considerably in size. Three partly articulated but incomplete skeletons assigned to Rhabdognathus sp. shed new light on the osteology and permit a first attempt at skeletal reconstruction of a longirostrine dyrosaur. Three hyposaurines (Hyposaurus nopcsai, Rhabdognathus compressus, Rhabdognathus sp.) and one phosphatosaurine (Phosphatosaurus sp.) are recognized from rostral fragments and frontal bones. Such diversity, noted in other occurrences, may reflect ecological segregation manifested in specialized rostral and dental characters and by individual size.

The braincase of Rhabdognathus sp. is exceptionally well ossified and is greatly attenuated anteriorly by prolongation of the laterosphenoids and the basicranial axis. Olfactory and optic nerves passed forward through separate tunnels formed by these bones. The structure probably increased the strength of the cranial axis otherwise lessened by the long temporal fossae and slender temporal arcades.

Hyposaurine dyrosaurs possessed relatively powerful forelimbs, suggesting derivation from terrestrial ancestors. Extremely high neural spines in the posterior trunk and tail may have enhanced swimming capability, and also limited vertical flexion of the body. The cranio-cervical joint and shape of the cervical vertebrae confirm Buffetaut's interpretation of restricted lateral but increased vertical ranges of motion in the neck. Massive and broadly overlapping dorsal osteoscutes lack anterolateral peg and socket articulations.

The Saudi Arabian material shows little evidence of disease, but injury during life is evinced by an amputated and partly healed femur. Gastroliths are associated with some specimens.
\end{abstract}

\footnotetext{
IVertebrate Paleontology Laboratory, The University of Texas at Austin, Balcone Research Center, Austin, Texas 78712.
}

\section{INTRODUCTION}

Many remains of dyrosaurs were found by joint U.S. Geological Survey-Saudi Arabia field parties in 1976-78. No fewer than 45 individuals of varying sizes are represented in the collection. Most of the material consists of incomplete vertebrae, limb bones, and other fragments collected on the surface, but three incomplete skeletons were also found in situ.

Whereas the Dyrosauridae are well defined on both cranial and postcranial features, effective generic and specific discrimination within the family is as yet restricted to cranial and mandibular characters, which reflect differing feeding adaptations (Moody and Buffetaut, 1981; Buffetaut, 1982). A number of descriptive accounts of dyrosaur remains have been published since Owen first recognized Hyposaurus rogersii in 1849 (for a taxonomic history of the Dyrosauridae, see Buffetaut, 1976a,b, 1982). The most comprehensive description of a dyrosaur skeleton is that of the North American Maastrichtian Hyposaurus natator (Troxell, 1925). Troxell's study was augmented by a description of an incomplete skeleton of Hyposaurus (=Congosaurus) bequaerti (Dollo) by Swinton (1950). Interestingly, neither species was recognized as dyrosaurian at the time (see Buffetaut, 1976b). Arambourg (1952) provided additional data on Dyrosaurus phosphaticus (Thomas), and descriptions of the skull of $D$. phosphaticus by Thevenin (1911), by Piveteau (1935), and lately by Buffetaut (1982) have furnished most of our knowledge about the cranial anatomy of the slender-snouted dyrosaurs. Of massive-headed forms, Buffetaut $(1978 \mathrm{a} ; 1979)$ has described the skulls of Sokotosuchus ianwilsoni Halstead and Phosphatosaurus gavialoides Bergounioux. Storrs (1986) has recently described an incomplete dyrosaur skeleton from the Paleocene of Pakistan. Nevertheless, many aspects of dyrosaurian osteology remain to be seen. The Saudi Arabian material sheds additional light on some questions, and permits for the first time a tentative skeletal reconstruction of this unusual crocodilian taxon. 


\section{ACKNOWLEDGMENTS}

I am indebted to C.T. Madden and F.C. Whitmore, Jr., for allowing me to study the Saudi Arabian dyrosaur material collected by Madden and his associates. I am also indebted to A.B. Busbey III, for his comments and careful criticism.

All specimens described herein are the property of the Kingdom of Saudi Arabia. They are numbered according to the localities of Madden and consecutively within each locality: no. 37-CR-1 means the first numbered crocodilian specimen from Madden's locality 37. All locality numbers bear the prefix USGS SAP indicating the U.S. Geological Survey-Saudi Arabian collection, but the acronym has been omitted in the text in the interest of brevity.

\section{OCCURRENCE}

The specimens described below were derived from 15 of 21 vertebrate-producing sites in the vicinity of Jabal Umm Himar, a large hill $100 \mathrm{~km}$ east of At Taif and $26 \mathrm{~km}$ west of Turabah, in southern Hijaz Province, Kingdom of Saudi Arabia (fig. F1).

All of the material was recovered from a well-defined 2-3-m-thick, massive, thick-bedded, green-gray mudstone at the base of the middle member of the Umm Himar Formation of Paleocene age. The source of these sediments has been interpreted as a lagoonal or estuarine environment subject to little or only gentle current action (Madden and others, 1979, Chap. A, this volume). It is significant that all fossils occurred roughly on strike over a distance of only $4.5 \mathrm{~km}$. This fact increases the likelihood that they represent nearly coeval events.

Most localities produced only weathered and fragmentary material of little importance except to demonstrate the presence of dyrosaurs in the Umm Himar Formation at those places, and to provide data on the size range of the individuals.

\section{IDENTIFICATIONS}

Taxonomically useful specimens in the collection are:

Number Description

2-CR-2 Posterior end of mandibular symphysis.

2-CR-4 Section of mandibular rostrum, including anterior end of splenial symphysis.

2-CR-5 Fragment of mandibular rostrum.
Number Description

3-CR-2 Short piece of mandibular rostrum anterior to splenia symphysis.

27-CR-1 Frontal plate.

27-CR-2 Section of mandibular rostrum.

33-CR-9 Incomplete skeleton, including braincase, temporal arch fragments, parts of the rostrum and postcranial elements.

37-CR-1 Partly articulated skeleton, including posterior part of braincase, postorbital bone, parts of the rostrum, quadrate, and articular region of the mandible, and a large part of the postcranial skeleton.

37E-CR-2 Fragment of mandibular rostrum.

43-CR-1 Incomplete mandibular symphysis.

58-CR-1 Partly articulated skeleton, including posterior part of braincase, segment of the mandibular rostrum and postcranial elements, and a large part of the postcranial skeleton.

60-CR-4 Fragment of rostrum.

Phosphatosau-
rus $\mathrm{sp}$.

Numbers 2-CR-5, 3-CR-2, 37E-CR-2, and 58-CR-1 display the reduced seventh tooth that is distinctive of the family Dyrosauridae (Buffetaut, 1976a). An incomplete left postorbital bone associated with no. 37-CR-1, but not certainly belonging to the skeleton from locality 37 , retains the broken base of the characteristic dyrosaurid postorbital spur (see Buffetaut, 1976a). Temporal arch bones with no. 33-CR-9 indicate the presence of a distinctively huge elongate supratemporal fenestra of dyrosaurid proportions. Braincases belonging to nos. 33-CR-9, 37-CR-1, and 58-CR-1 are uniquely dyrosaurian. All other material in the collection is morphologically consistent with what is currently known about the dyrosaurid skeleton.

All rostral fragments except no. $60-\mathrm{CR}-4$ are evidently from slender-snouted dyrosaurs of the subfamily Hyposaurinae Buffetaut (1980). These specimens differ considerably in size and shape and represent different segments of the snouts (fig. F2). The variety of these specimens brings to mind a curious phenomenon within the Dyrosauridae: several closely similar species often occur in the same deposits. Swinton (1930), for example, described an assemblage of 17 rostral fragments from Paleocene rocks at Wurno, in northwestern Nigeria. Among them he recognized three new genera and species: Wurnosaurus wilsoni, Rhabdognathus rarus, and Sokotosaurus nopcsai; and, on the basis of the occipital end of a skull, he named a new species of Dyrosaurus, D. minor. Although the existence of three or four closely similar longirostrine forms in such close 

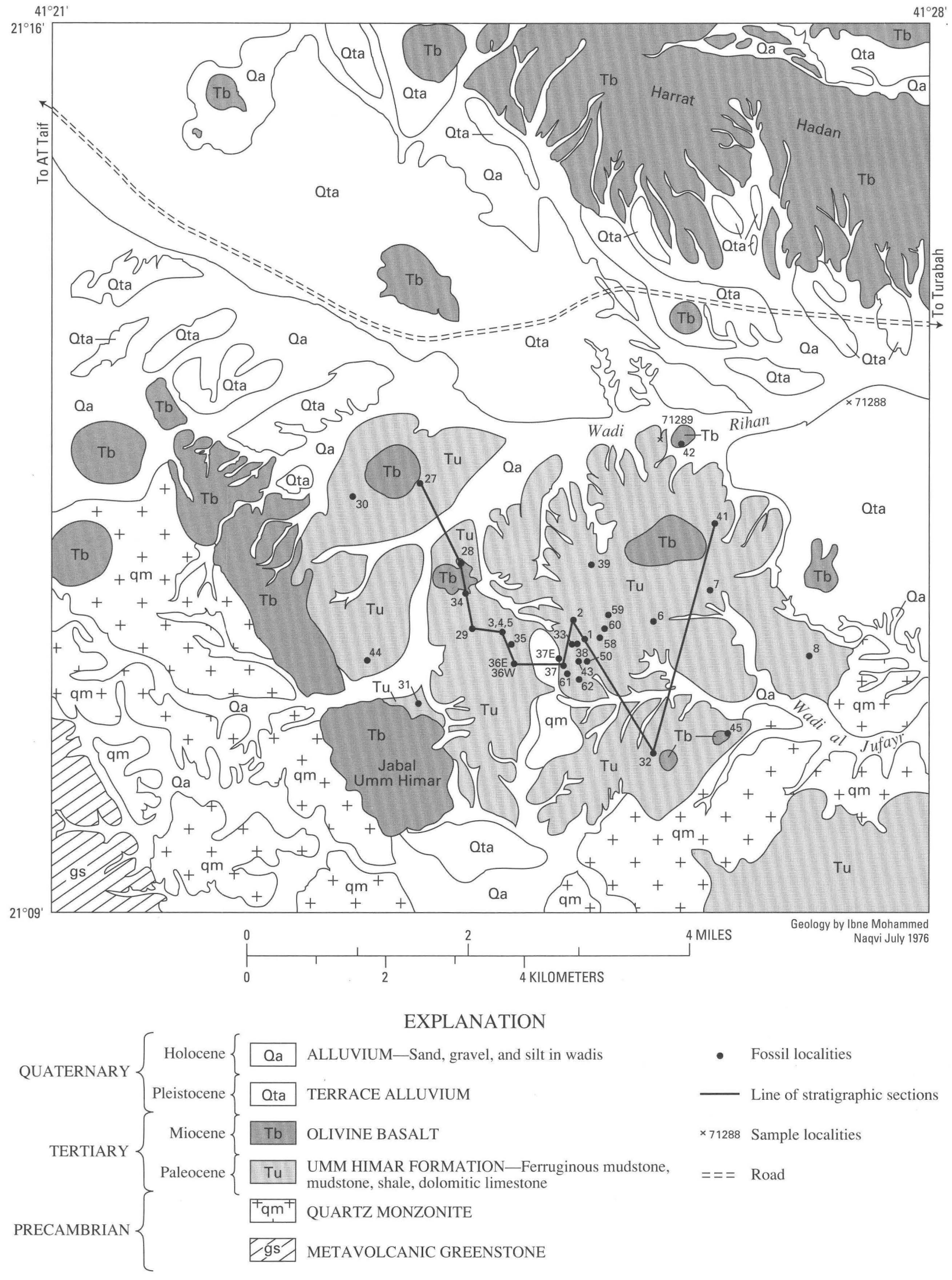

Figure F1. Geologic map of Jabal Umm Himar area, showing fossil sample localities and line of stratigraphic sections (fig. A3). 


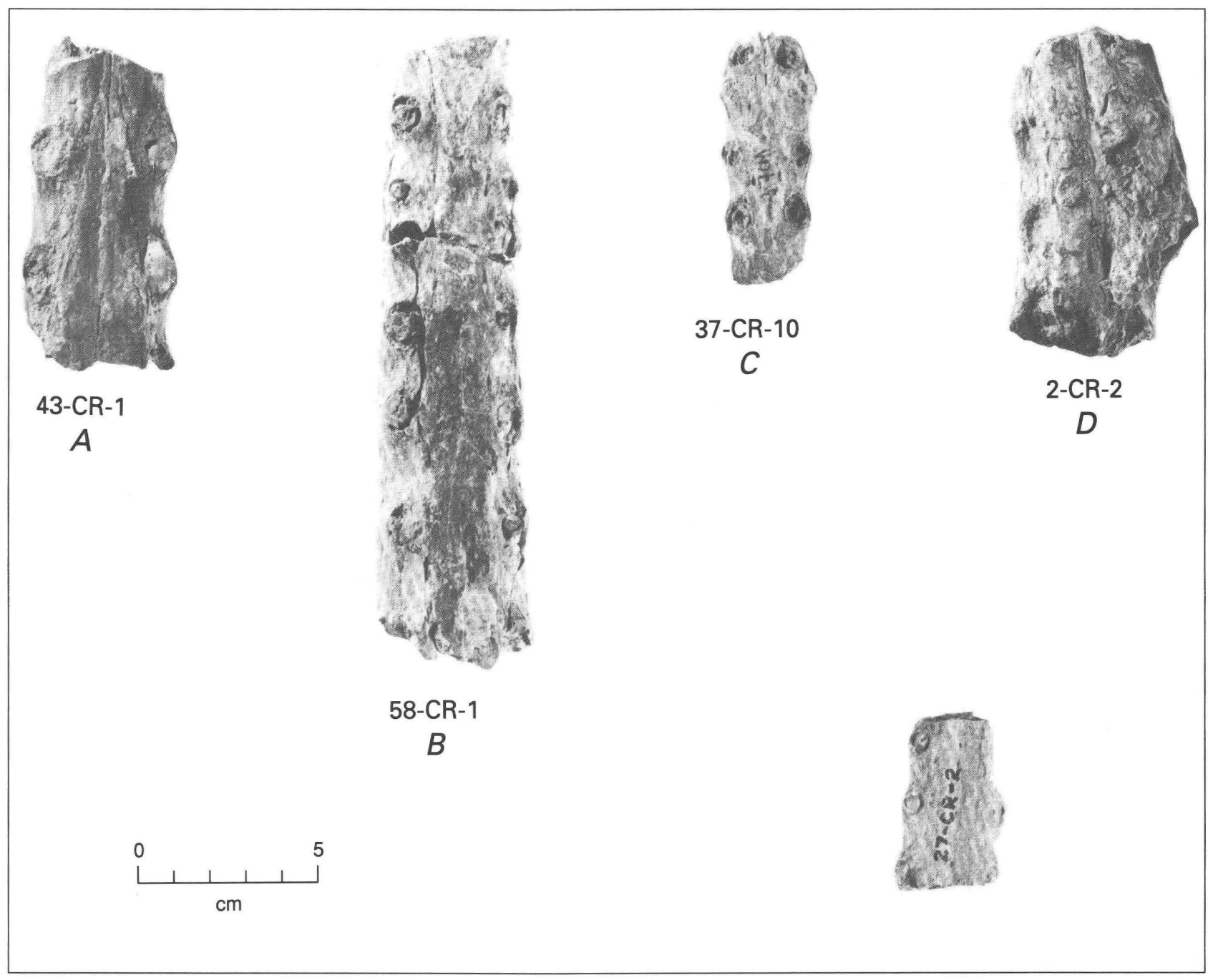

Figure F2. Mandibular rostra of dyrosaurs from Saudi Arabia. A-C, Rhabdognathus sp.; D-E, Hyposaurus nopcsai.

proximity as implied in Swinton's study is suspect on ecological grounds, his specimens are different, and most recent writers (Steel, 1973; Halstead and Middleton, 1976; Buffetaut, 1979, 1980) accept the validity of the species. Buffetaut (1980), however, reassigned Wurnosaurus and Sokotosaurus to the genus Hyposaurus, and Halstead and Middleton (1976) synonymized D. minor with Rhabdognathus rarus. Similar assemblages are reported from Mali and elsewhere (Buffetaut, 1980).

Swinton, among others, emphasized the cross-sectional shape of dyrosaur rostra as a taxonomic tool (fig. F3). The outline, however, may be expected to vary somewhat with size of the individual and the positions of the sections along the rostrum. Sections may vary radically when taken through the alveoli and the adjacent interalveolar spaces (figs. $\mathrm{F} 3 H, I$ ), so cross sections of rostra must be used with some caution.

Rostra associated with the incomplete skeletons of nos. 33-CR-9, 37-CR-1, and 58-CR-1, and isolated specimens
37-CR-7, 37-CR-10, 43-CR-1, and 37-CR-12 conform fairly well to Buffetaut's (1980) revised definition of Rhabdognathus. In most of the specimens it is impossible to tell where the splenial symphysis ends in relation to the dental sequence, but in no. 58-CR-1 this point is at the level of the tenth tooth, as in Rhabdognathus. The transverse separation between alveoli is, however, greater than in known species of this genus, and the alveolar salients are less marked than in $R$. rarus. The uniform occurrence of these differences throughout the Saudi Arabian sample is suggestive, but the taxonomic value of such features standing alone seems doubtful to me. Rather than add another ill-defined taxon to the literature I will refer these specimens to Rhabdognathus $\mathrm{sp}$.

Two rostral fragments, nos. 2-CR-4 and 3-CR-2 (figs. F3 $G-I ; \mathrm{F} 4)$, are strikingly different from the others in the collection. They are about as high as wide in cross section, but their sides are flatter than in Rhabdognathus sp., the teeth are more widely spaced, and the distance between 


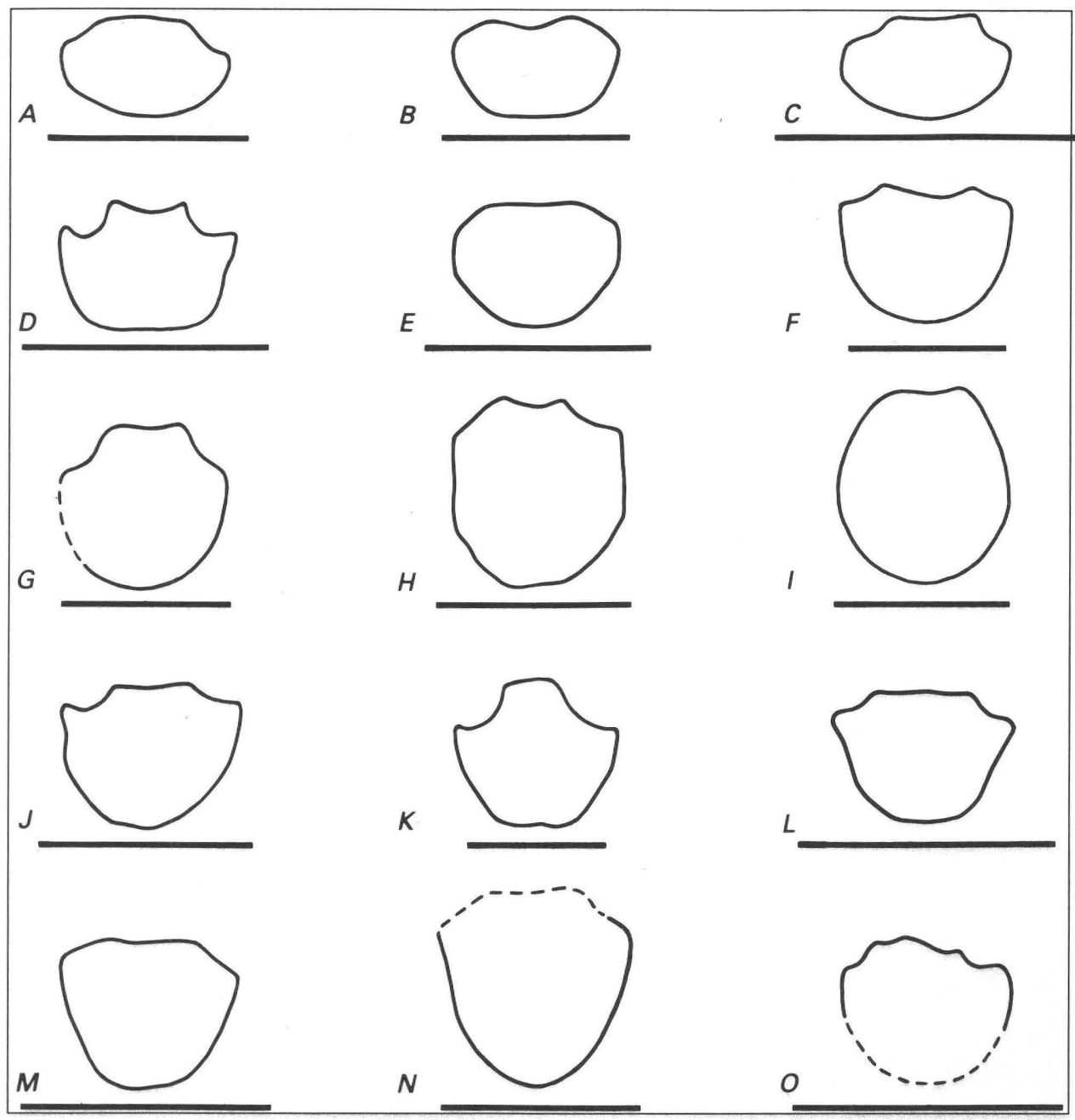

Figure F3. Cross sections of dyrosaurian mandibular rostra, drawn to the same scale. All sections except $I$ are through alveoli. A, Hyposaurus (= Wurnosaurus) wilsoni (Swinton), section near tip of splenial symphysis; B, Hyposaurus nopcsai (no. 27-CR-2), section forward of the tip of the splenial symphysis; $C, H$. nopcsai (no. 2-CR-2), section near end of symphysis; $D$, Hyposaurus (= Sokotosaurus) nopcsai (Swinton), holotype, section near anterior tip of splenial symphysis; $E, H$. nopcsai from Swinton, 1930; F, Dyrosaurus phosphaticus Thomas; G, Rhabdognathus compressus (no. 3-CR-2), section at level of 9th tooth; $H, R$. compressus (no. 2-CR-4); $I$, the same drawn through inter-alveolar space; $J$, R. rarus Swinton (lectotype, Halstead and Middleton, 1976), section at level of 6th tooth; $K, R$. rarus (syntype of Swinton, 1930), section near anterior end of rostrum, possibly at 3rd tooth; L, Rhabdognathus sp. (no. 37-CR-1), section at level of ?4th tooth; M, Rhabdognathus sp. (no. 43-CR-1), section near end of splenial symphysis; $N$, Rhabdognathus sp. (no. 33-CR-9), section at level of 4th tooth; O, Rhabdognathus sp. (no. 58-CR-1) section at level of 10th tooth. Sections of Swinton's specimens $(C, D, J, K)$ are new, drawn from casts; $F$, redrawn from Buffetaut and others.

opposite alveoli is as much as two times the width of the alveoli. Alveolar salients are not strongly developed. The alveoli are narrowly oval, with the width equal to about 64 percent of the length. The long axis of the alveoli slants diagonally outward behind. The broken crowns of teeth are strongly compressed laterally, a little thicker anteriorly than posteriorly, and the thickly enameled outer surface bears strong longitudinal ribbing (the condition of the lingual side of the crown is undetermined). The teeth have remarkably long roots. Although in cross section these rostral fragments are perhaps less elevated and more rounded than implied in Buffetaut's definition of Rhabdognathus compressus, the dental characters of these specimens are sufficient to place them in that species.

The posterior part of a mandibular symphysis (no. 2-CR-2) is transversely oval in section, similar to Hyposaurus wilsoni, but the alveoli are larger and closer together than in that species. The buccal surface is concave transversely, instead of arched as in $H$. wilsoni. This specimen and no. 27-CR-2, a short segment of another rostrum from 
farther forward (figs. $\mathrm{F} 2 D, E ; \mathrm{F} 3 B, C$ ), are best assigned to $H$. nopcsai. This disposition appears to be confirmed by a frontal plate (no. 27-CR-1; fig. F5B), which resembles the frontals referred to Sokotosaurus by Halstead and Middleton (1976, fig. 7j). While those authors' argument for this assignment is not completely convincing, this solution seems preferable to regarding the pitted frontals as an atypical (?atavistic) Rhabdognathus.

A well-preserved frontal plate (no. 2-CR-3) is very similar in outline to no. 27-CR-1, but differs in lacking pitted sculpture and in the slight transverse depression of the interorbital plate (fig. F5C). It may belong to Rhabdognathus sp. The anteromedial edge of the supratemporal fenestra is more angular than in H. nopcsai.

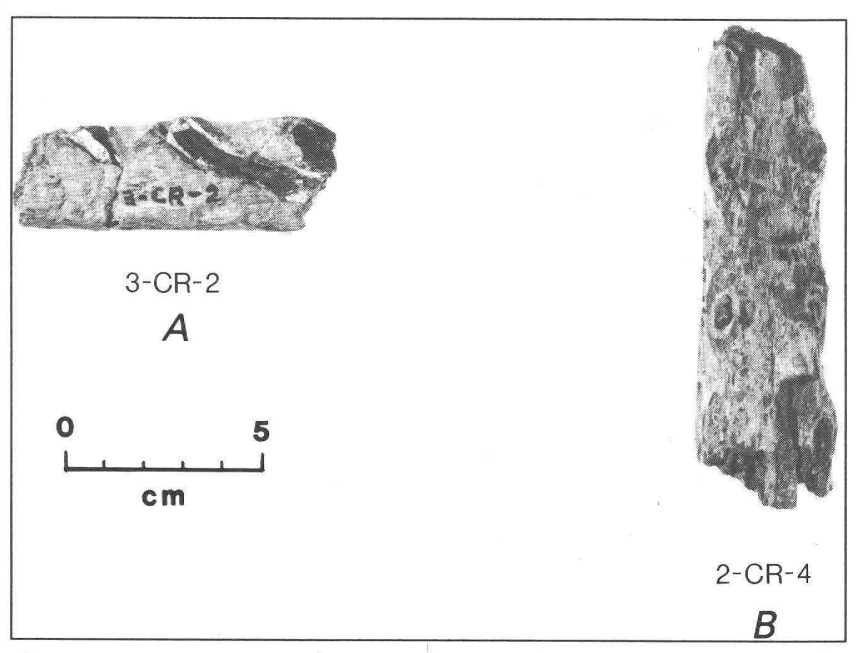

Figure F4. Rhabdognathus compressus. A, lateral view of mandibular segment with tooth root exposed; $B$, dorsal view of mandibular rostrum showing laterally compressed teeth in section and oval alveoli.
Specimen no. 60-CR-4 consists of several weathered large and massive rostral fragments. Some vertebrae and limb segments associated with them in the field are not unusually large, so no. 60-CR-4 clearly represents more than one individual. One large piece, evidently from the cranial rostrum, contains one nearly complete subround alveolus with a transverse diameter of $29 \mathrm{~mm}$, and behind this is part of another alveolus of similar proportions. The teeth were curved but not so strongly bent as the teeth in Rhabdognathus sp. The two alveoli are separated by an interdental space of only $9 \mathrm{~mm}$ and neither of them is surrounded by an elevated rim. A large tooth (no. 60-CR-6) is poorly preserved, being little more than a matrix cast of the pulp cavity with patches of dentine adhering near the tip and the root. Surface features are not preserved. The specimen is thick and although possessing a small nipple at the tip is clearly blunter than teeth in most dyrosaurs. It is slightly bent transversely but shows no anteroposterior curvature. It is broadly oval in cross section with transverse and fore and aft diameters of 18 and $25 \mathrm{~mm}$, respectively, at the base. The specimen is $57 \mathrm{~mm}$ high, but the intact tooth was, of course, larger than this.

Also from locality 60 is a small part of the anterior end of a mandibular rostrum probably belonging to no. 60-CR-4. This rostrum contains part of the side of a large recumbent tooth, probably the first. Only the inner side of the root is visible, but this contains a pulp cavity exceeding $20 \mathrm{~mm}$ in diameter. The preserved segment of the root is 78 $\mathrm{mm}$ long, and it is broken off at both ends. Dorsolateral to this tooth is the crown of a second recumbent tooth missing the outer surface. It is about $15 \mathrm{~mm}$ in diameter where broken off at the base and is $45 \mathrm{~mm}$ long as preserved. This tooth has not yet erupted, but its pointed tip is directed into what was evidently an alveolus with raised edges. Lacking the tip of this tooth, it is impossible to say how widely separated the first two teeth would have been. It is clear,
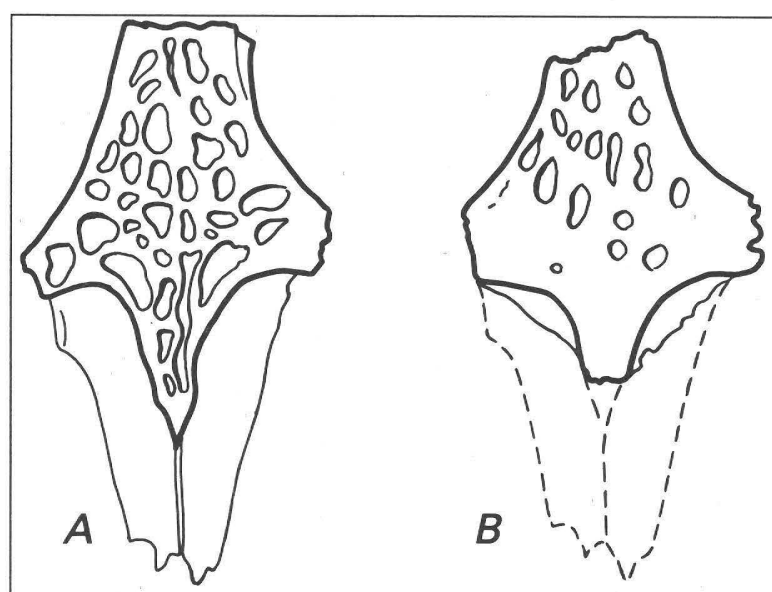

$27-\mathrm{CR}-1$

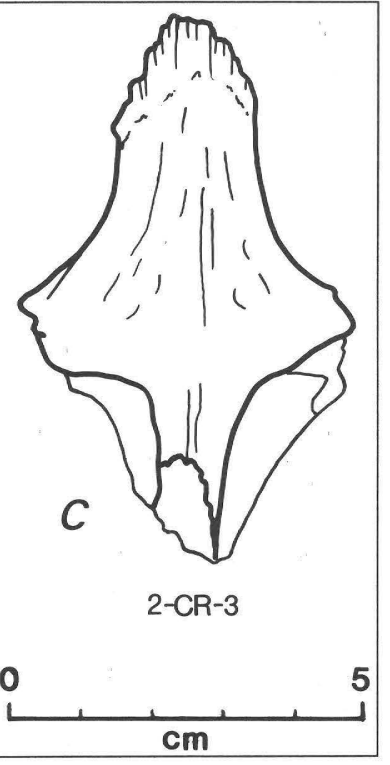

Figure F5. Frontal bones of dyrosaurs. $A$, frontal plate assigned to cf. Sokotosaurus Swinton (= Hyposaurus) by Halstead and Middleton, from the Dange Formation in Nigeria; $B$, $H$. nopcsai, referred specimen; $C$, frontal plate possibly belonging to Rhabdognathus sp. A redrawn from Halstead and Middleton, 1976. 
however, that the end of the rostrum was not expanded transversely.

A second, smaller, but more complete rostral end (no. 60-CR-5) confirms the interpretation of the larger fragment and appears to represent a smaller individual of the same species. It is clearly dyrosaurian. A third, less complete, tip agrees with the second.

Whether the diverse fragments from locality 60 belong to the same species is not clear, but I believe all the rostral parts at least are attributable to one species. The close spacing of the teeth and the lack of elevated alveolar rims in no. 60-CR-4 suggest they are from the posterior part of the snout. The characters noted agree with Phosphatosaurus gavialoides Bergounioux (1955), previously known from the Paleocene of Mali and Niger and the lower Eocene of Tunisia (for a description and illustrations of $P$. gavialoides, see Buffetaut, 1978a). But scant basis exists for distinguishing the large form from locality 60 from the Late Cretaceous Sokotosuchus ianwilsoni Halstead, from Niger, which resembles Phosphatosaurus in those features preserved in no. 60-CR-4. Nevertheless, I shall tentatively assign the Saudi Arabian material to Phosphatosaurus sp., because, other things being equal, its geological age is more in accord with Phosphatosaurus than with Sokotosuchus.

A thick, bent tooth crown (no. 28-CR-1) may belong to Phosphatosaurus, but it is much smaller than the specimens from locality 60 . The crown is almost smooth, but it has a sharp carmina on its anterior edge. It is curved both anteroposteriorly and medially.

Thus, as at Wurno and in Mali, several species of dyrosaurs seem to occur in close association at Jabal Umm Himar.

Such diversity may have been an accident of taphonomy; however, the phenomenon now evident in at least three widely separated localities may reflect natural associations. Ecological segregation was perhaps affected by differing habits reflected in disparate head and tooth forms and body size.

\section{OSTEOLOGICAL NOTES}

There is a considerable body of literature dealing with the osteology of dyrosaurs. The most recent comprehensive contribution is by Buffetaut (1982), but no complete account of the skeleton has yet been published. The following notes emphasize certain aspects observed for the first time in the Saudi Arabian material. The most useful specimens are the three skeletons nos. 33-CR-9 and -10, 37-CR-1, and 58-CR-1, of which the last two were found partly articulated and are more complete than the first. Material from other localities will be discussed as appropriate. I presume that most if not all of the specimens are attributable to Rhabdognathus sp., but I suspect that for postcranial elements these notes are generally applicable to any of the more advanced Hyposaurinae.

Skull.-The dyrosaur head skeleton is fairly well known through descriptions of $D$. phosphaticus by Thevenin (1911), Arambourg (1952), and Piveteau (1935), of Hyposaurus natator by Troxell (1925), and of Phosphatosaurus gavialoides and Sokotosuchus ianwilsoni by Buffetaut (1978a; 1979). Although illustrations of almost complete hyposaurine skulls and jaws exist-D. phosphaticus (Thevenin, 1911, pl. 1), Rhabdognathus rarus, and (Buffetaut, 1980, pl. 2)-these have not been described fully. The Saudi Arabian material adds little more to existing knowledge, but the anterior part of the braincase in no. 33-CR-10 and well preserved occipital segments of this specimen and nos. $37-\mathrm{CR}-1$ and $58-\mathrm{CR}-1$ provide some new data of importance.

Most of the skull and jaw material in the Saudi Arabian collection is badly shattered and concerted attempts to reassemble the specimens have not been very successful. In addition to the braincase, material from locality 33 includes the tip of the rostrum, with upper and lower jaws tightly interlocked when found (a frequent occurrence in slendersnouted dyrosaurs); the left postorbital and squamosal bones; and several fragments of the temporal arcades. Many fragments of the rostrum contain teeth. It is presumed that all these parts are derived from one individual (no. 33-CR-10): Specimen no. 37-CR-1 includes the anterior end and about the posterior half of the mandibular rostrum, with the palatal part of the cranial rostrum attached when discovered; the occiput; the right quadrate; and various fragments. The articular part of the left mandible is also present. However, locality 37 , like locality 33 , has yielded cranial remains of other individuals, including the anterior end of a left mandible (no. 37-CR-7), a basicranium (no. 37-CR-9), a tip of a very small mandibular rostrum (no. 37-CR-20), a fragmentary left postorbital (no. 37-CR-11), and other fragments. Specimen no. 58-CR-1 contains the middle third of the mandibular rostrum, with the opposing palatal bones attached in matrix; a badly crushed posterior segment of the rostrum; the well-preserved occipital and otic region of the skull; and several teeth.

As in other long-snouted dyrosaurs, the cranial bones are lightly sculptured, the dominant feature being long grooves and ridges, with pitting largely confined to the temporal arches and the angular and surangular bones.

The external nares, surrounded by the premaxillae, are undivided, but posteriorly they are entered by a short narial spine formed exclusively of the premaxillae (fig. F6A). In outline they are broadly pear shaped, a little wider in front than behind, and about five-sixths as wide as they are long. The narial opening is higher posteriorly than anteriorly, so it is directed forward as well as upward (fig. F6B). The incisive foramen, seen through the nares, is slitlike, a little wider in front than behind, and rises anteriorly between the premaxillae. An attempted reconstruction of the postrostral 


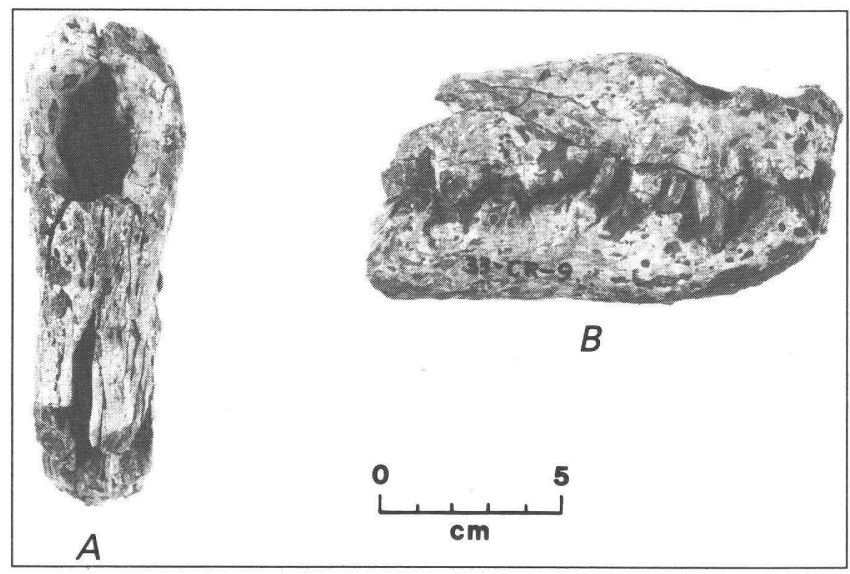

Figure F6. Rhabdognathus sp., no. 33-CR-9. End of interlocked cranial and mandibular rostra. $A$, from above; $B$, from the side.

skull (fig. F7) shows that the supratemporal fenestra of Rhabdognathus sp. had the same proportions seen in Dyrosaurus and the orbits were correspondingly small. The parietal space between supratemporal fenestrae is reduced to a narrow ridge.

The frontal participated extensively in the supratemporal fenestrae, sending back a distinct sagittal crest between them. This crest, which is $7 \mathrm{~mm}$ wide, rises slightly toward the rear. The least interorbital distance in no. 2-CR-3 is 20 $\mathrm{mm}$, and the greatest transverse diameter (across the postorbital processes) is $46 \mathrm{~mm}$. The parietal ramus of the frontal is longer than in other crocodilians and posteriorly it divides, overlapping the sides of the parietal with long posteriorly acute processes. This arrangement is altogether different from the transverse and usually blunt fronto-parietal contact in eusuchians.

The frontals are supported anterolaterally by the extremely elongated laterosphenoids (fig. F10). The parietals, best seen in no. 33-CR-10, display the same relationships to adjoining bones as in eusuchians, due allowance being made for the longitudinal attenuation of all the elements. As in a specimen of Dyrosaurus figured by Lavocat (1955) and Buffetaut (1982), the parietal plate descends in a broad V-shaped pattern onto the posterior face of the occiput, thus excluding the supraoccipital from the skull roof.

The rostrum is elevated, a feature noted elsewhere in D. phosphaticus by several authors. At the level of the fifth upper tooth (MX 1), the rostrum, including the mandible, is $33 \mathrm{~mm}$ wide and $64 \mathrm{~mm}$ high in no. 33-CR-9. The sutural relationships between the premaxilla and maxillae are as depicted in D. phosphaticus by Piveteau (1935, fig. 7). The coalesced nasal bones do not reach the nares.

The right quadrate of no. 37-CR-1 lacks its proximal end and part of the medial condyle, but the distal end is perfectly preserved in no. 37A-CR-1 (fig. F8). What remains of the quadrate in no. 37-CR-1 is an oblong piece $91 \mathrm{~mm}$ long

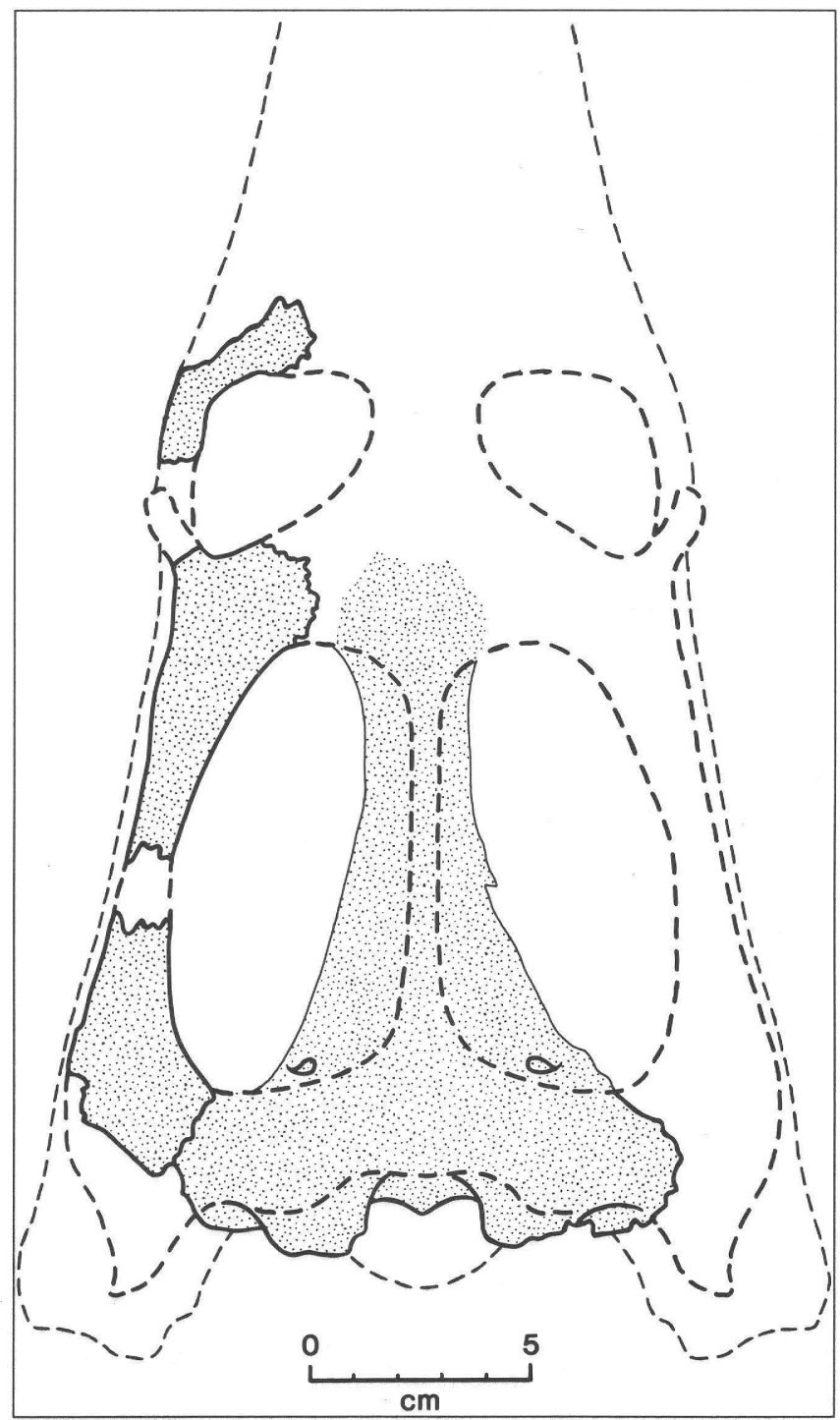

Figure F7. Rhabdognathus sp. Reconstruction of the post-rostral skull, from above, based on no. 33-CR-10.

and $40 \mathrm{~mm}$ wide at the condylar end. That part which extends beyond the end of the paroccipital process seems much longer in relation to its width than in living crocodilians. Whether this resulted in an attenuated suspensorium as is suggested in some published illustrations (Piveteau, 1935, fig. 9; Buffetaut, 1980, pl. 2-2) or is merely an illusion owing to a wider contribution by the quadratojugal, is unknown. The articular condyle (fig. F9) is more broadly exposed dorsally than below. The lateral part is well rounded dorsoventrally and curves around onto the dorsal surface to a greater extent than in eusuchians. The medial condyle is larger than the lateral condyle, but it was extended more onto the posteroventral side of the quadrate. The intercondylar notch is broad and shallow. The lateral condyle is sharply truncated where it joined the quadratojugal to complete the cranial articulation. A small notch on the medial edge near the posterior end is located where one 


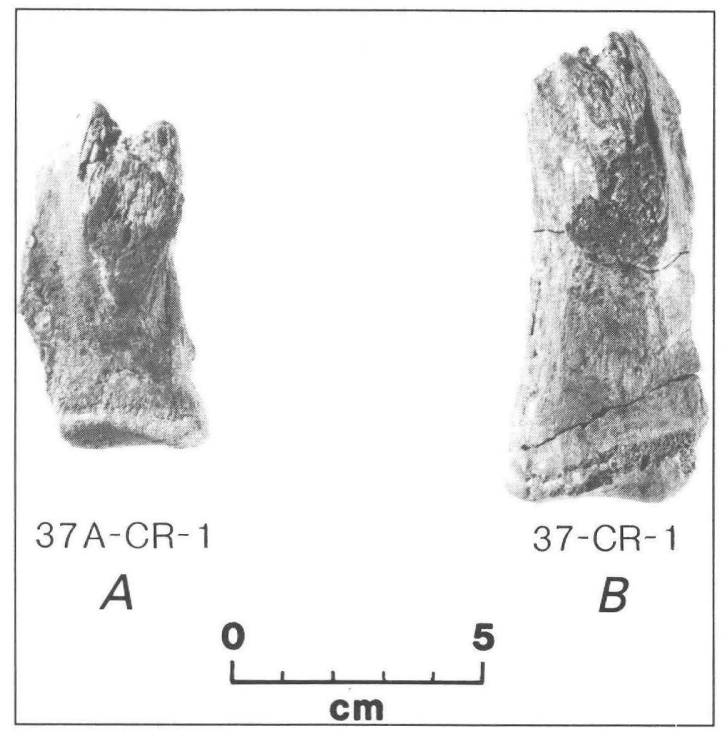

Figure F8. Rhabdognathus sp. Quadrate bones from above. $A$, left; $B$, right.

would normally expect the aeriferous foramen, but an actual opening in the bone is not apparent. A fragment of the left quadrate bears a strong rounded tendon scar adjacent to its quadratojugal edge. This probably corresponds to crest $\mathrm{A}$ of Iordansky (1973) and is situated in about the same position as this crest in Crocodylus acutus. In no. 37A-CR-1 the crest occurs a little more medially. A piece of what may be part of the united quadratojugal and jugal is preserved, but the condylar part of the quadratojugal is missing. In Hyposaurus natator, the quadratojugal is said to compose about one-fourth of the cranial jaw hinge (Troxell, 1925), and Buffetaut (1975) has pointed to this as a fairly common feature of long-snouted mesosuchians.

The occipital region of the dyrosaurian skull is a massive structure that is frequently found more or less intact. Several of these have been figured (Swinton, 1930, pl. 4, 5; Piveteau, 1935, fig. 9; Lavocat, 1955, fig. 1; Buffetaut, 1980, pl. 2-2, 1982, figs. 17, 18). Occipital masses belonging to nos. 33-CR-10, 37-CR-1, and 58-CR-1 are present in the Saudi Arabian collection, and no. 33-CR-10 is attached to the anterior end of the braincase. These specimens, which await further preparation, should provide new data on the endocranial cavity and otic structures. The posttemporal fenestra occurs on the posterodorsal edge of the occipital face as a wide but slitlike opening. It passes inward beneath the roof of the parietal and the medial branch of the squamosal. Its path slants downward through the occipital mass and emerges in a transversely oval foramen on the posterior wall of the supratemporal fossa (fig. F10, posterior-most arrow). The foramen magnum is subtriangular in outline with the apex downward. It is bounded largely by the exoccipitals with a minor contribution from the basioccipital in an arrangement not unlike that seen in many eusuchians. Such features as the huge occipital tuberosities and greatly

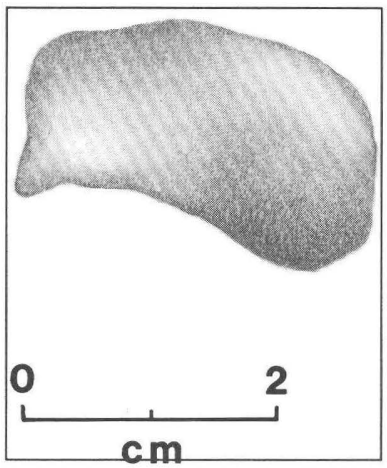

Figure F9. Rhabdognathus sp., no. 37A-CR-1. Distal (articular) end of left quadrate (superior surface at top).

expanded periotic bullae are well described by Swinton (1930), Lavocat (1955), and Buffetaut (1982), and require no further elaboration. The virtual median contact achieved between opposite periotic bullae within the endocranial chamber must have resulted in a curious separation of the longitudinal head sinus from the dorsal surface of the hindbrain. The sinus must have risen up through an oval passageway posterodorsal to the bullae, thence passing forward above them through a restricted channel, and then rejoined the brain, so to speak, near the cerebellum in a large vaulted area of the endocranial roof. Foramina, which transmitted various branches of the longitudinal sinus, can be seen in the walls of this space.

A striking feature of the braincase is its forward attenuation (fig. F10). The laterosphenoids unite in the midline beneath the forebrain, and join the parietals and frontals dorsolaterally. This produces an elongate bony tunnel through which passed the olfactory peduncles (in all other mesosuchians and eusuchians the corresponding area is mostly cartilaginous, Hopson, 1979). Below this olfactory tunnel is another enclosed passageway, which carried the optic nerves forward. This passageway is formed by upward and forward expansion of the basisphenoidal rostrum, which, unlike the condition in other crocodilians, unites suturally with ventrolaterally expanded ridges of laterosphenoid. At its anterior end, this optic tunnel has about the same diameter as the exit of the olfactory tunnel, but the olfactory tunnel expands greatly posteriorly into a vertically oval space, whereas the optic tunnel remains about the same diameter throughout its length. The optic tunnel is shorter than the olfactory tunnel, ending anteriorly about $27 \mathrm{~mm}$ from the end of the fused laterosphenoids in no. 33-CR-10. Paired channels on the ventral surfaces of the combined laterosphenoids lodged the optic nerves for a short distance beyond their exit from the optic tunnel. Here, the basisphenoidal rostrum probably separated from the laterosphenoids and projected a short distance forward as a process. This process, however, appears to have been slender and rod shaped, and not a vertically expanded, laterally compressed basisphenoidal rostrum as seen in other crocodilians.

The hypertrophy and other structural modifications in the anterior part of the braincase and basicranial axis may have strengthened the axis in a region otherwise weakened 


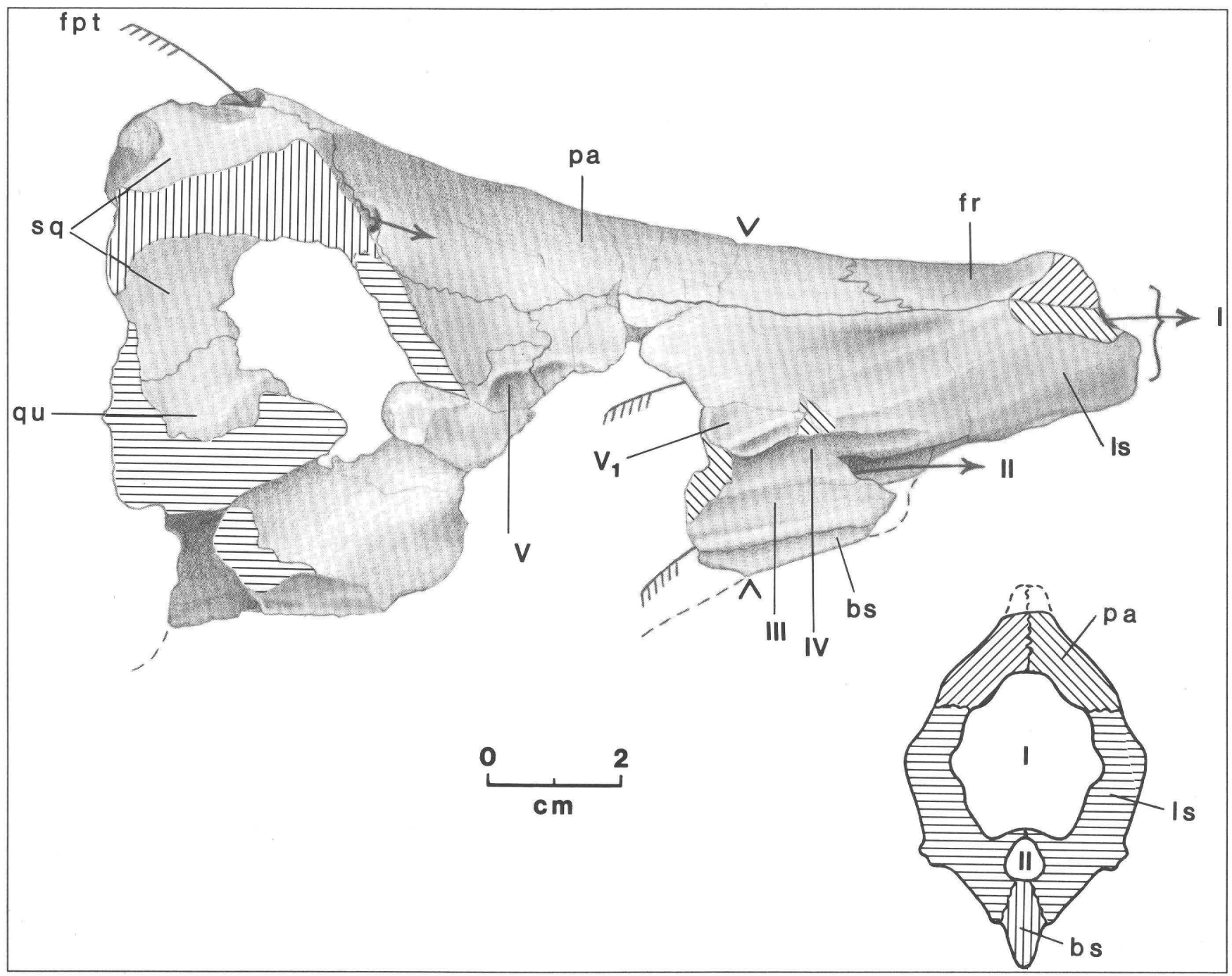

Figure F10. Rhabdognathus sp., no. 33-CR-10. Braincase from the right side. Lower right, transverse section at $\stackrel{\vee}{\wedge}$; bs, basisphenoid; fpt, posttemporal fenestra; fr, frontal; ls, laterosphenoid; pa, parietal; qu, quadrate; sq, squamosal; I-V, paths of cranial nerves. Passages through bones indicated by arrows (see text).

by attenuation of the temporal region and its relatively narrow lateral bony arcades.

Except for those just described, cranial foramina are not visible in the specimens. A large lateral excavation posteriorly on the laterosphenoid probably housed part of the trigeminal ganglion. Farther forward, on the ventrolateral surfaces of the laterosphenoid-parasphenoid complex, are various longitudinal channels that probably lodged the ophthalmic ramus and the motor branch of the trigeminal nerve to the levator bulbi muscle (see Hopson, 1979).

Foramina associated with the eustachian system are as discussed by Lavocat (1955).

Although the proportions of the braincase are unusual, it must be stressed that all structures except the dorsal longitudinal sinus retain the usual crocodilian interrelationships. The unique features are owing to proportional differences and not to deviations from the crocodile plan of organization. The braincase has simply been stretched forward, or backward, as the case may be, in conjunction with the elongation of the temporal fossae. The tubular construction of the anterior braincase is no doubt related to a need to strengthen this part of a long slender head against the stresses generated by very powerful jaw muscles. While such attenuated braincases may be expected in crocodilians with elongated temporal fossae, I am unaware of any detailed description of such. Somewhat similar conditions are described in Metriorhynchus, but according to Wenz (1968) the extent and relationships of the laterosphenoid are comparable to those in existing crocodilians. Nothing is said about a tunnel for the optic nerves as occurs in the dyrosaur neurocranium. The condition appears analogous to that which produced the closing of the secondary palate in crocodilians (see Langston, 1973). 
Interestingly, the braincase of the recently described Late Triassic protosuchian, Eopneumatosuchus, which does not have excessively elongate supratemporal fenestrae, nevertheless possesses an attenuated laterosphenoid and various longitudinal lateral sulci for cranial nerves on the side of the braincase somewhat evocative of the dyrosaur conditions (Crompton and Smith, 1980).

Mandible.-Some features of the anterior end of the mandible have already been noted. The rostrum is not expanded anteriorly. The seventh tooth is reduced in size. The rostrum widens gradually posteriorly. The splenial symphysis ends anteriorly at the level of the tenth dentary tooth, on the dorsal side of the rostrum in no. 58-CR-1. On this basis the length of the presplenial rostrum of no. 37-CR-1 is estimated at about $215 \mathrm{~mm}$. Ventrally, the splenial appears to end in a point somewhere near the level of the 11th tooth; however, in the specimens where sutures can be seen there is a certain asymmetry in their arrangement, which gives the impression that one splenial bone extends much farther forward than the other. In no. 37-CR-1 this is the left splenial, whereas in no. 2-CR-2 it is the right. The tip of the shorter splenial is not visible in either specimen. Swinton (1930) speaks of splenials being visible on the ventral side of the jaw, but not on the oral side in a specimen referred to Sokotosaurus nopcsai, and of splenials in the same species, which lack any trace of a midline suture. A well preserved segment of rostrum no. 43-CR-1 shows no trace of either splenial in the ventral side at the level of the 12th tooth. The splenials in Hyposaurus bequaerti are regular in development (Swinton, 1950, pls. 2-4); however, aberrations in very long and slender splenials are not surprising. Thevenin (1911) believed that the angular and not the splenial formed the posterior part of the symphysis on the ventral side of the mandible in Dyrosaurus, but this has not been confirmed and is almost certainly in error.

A large part of the left articular bone and some of the adjacent surangular (fig. F11) are present in no. 37-CR-1. A small piece of the angular is attached. The dyrosaur surangular is unique in its large contribution to the glenoid fossa (Buffetaut, 1975). In the present specimen it forms almost half of the glenoid fossa and is thus even more extensive than in a dyrosaurid from the Paleocene of Mali figured by Buffetaut (1975, fig. 2a). The fossa is about $56 \mathrm{~mm}$ wide. It is limited behind by a low transverse elevation. A massive blunt process on the medial side projects forward to a greater degree than in any nondyrosaurian crocodile known to me. A comparable feature is evident in the jaw of Hyposaurus bequaerti (see Swinton, 1950, pl. 4) and in an unnamed dyrosaur from Mali (Buffetaut, 1975, fig. 2a). Buffetaut's drawing indicates that the medial condylar basin occupies only part of this projection, but no. $37-\mathrm{CR}-1$ has a smooth articular surface extending over its entirety. The anteroventral process of the articular, which ended in cartilage, was a thick plate of bone that descended more vertically into the adductor fossa than in existing crocodilians.

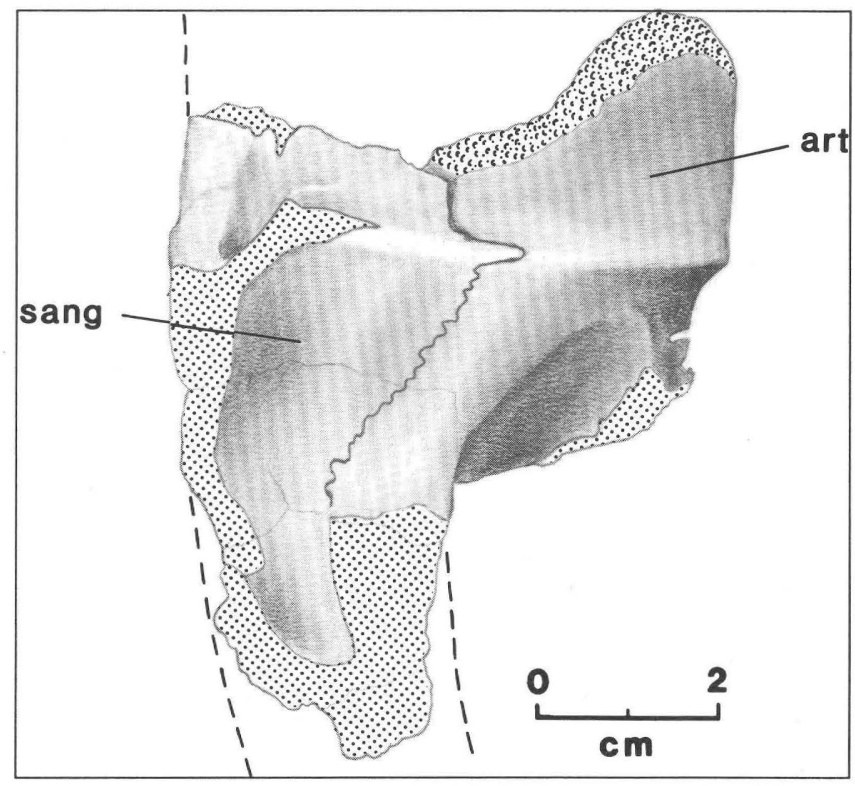

Figure F11. Rhabdognathus sp., no. 37-CR-1. Articular region of left mandible, from above. Art, articular; sang, surangular.

The articular forms the posterior side of this fossa, which is relatively much wider than in C. acutus, for example. Laterally, at the posterior edge of the glenoid fossa, is a large anteriorly directed foramen. This probably corresponds to a small foramen, which in existing crocodilians may enter the jaw from farther down in the adductor fossa, often in the suture between the surangular and the articular. It is far removed from this suture in no. 37-CR-1, however. Swinton (1950) reports a large foramen in the surangular of $H$. bequaerti, but says that it lies behind the hinder rim of the glenoid fossa. He compares it to the aeriferous foramen in other crocodilians. The opening cannot be the foramen for the siphoneum because its presence in the surangular and within the glenoid fossa makes no sense embryologically or functionally. On the other hand, no foramen for the siphoneum is evident on the preserved part of the articular in no. 37-CR-1. Behind the transverse posterior rim of the glenoid fossa, the articular expands diagonally across the base of the retroarticular process and no doubt took over most of the surangular's usual role in that process. The process is formed by the articular medially, the surangular dorsolaterally, and the angular ventrolaterally. It is evidently longer in dyrosaurs than in any other crocodilian (Swinton, 1950). The lateral surfaces of the surangular and angular bones are much more deeply pitted than other dermal bones of the head.

The mandibular alveoli are borne in salients that are formed by wide intervening notches in the dorsolateral edge of the dentary. The salients are often visible in ventral aspect, especially toward the front of the jaw.

The oral surface of the mandibular rostrum is arched transversely, and the alveoli open below the top of the jaw. 
Table F1. Interdental distances measured from the centers of the alveoli

[In millimeters]

\begin{tabular}{|c|c|c|c|c|c|c|c|c|c|c|c|c|c|c|}
\hline Alveolus & 1 & 2 & 3 & 4 & 5 & 6 & 7 & 8 & 9 & 10 & 11 & 12 & 13 & 14 \\
\hline 33-CR-9 .............. & & 17 & 23 & 21 & 26 & 23 & & & & & & & & \\
\hline 37-CR-1 ............... & & & 29 & 27 & & & & & & 31 & 31 & 31 & 31 & 31 \\
\hline 59-CR-1 ............... & & & & & & & 19 & 12 & 24 & 23 & 31 & 32 & & \\
\hline 37-CR-10 .............. & & 9 & 20 & 17 & & & & & & & & & & \\
\hline 37-CR-7 .................. & & 25 & & & & & & & & & & & & \\
\hline
\end{tabular}

Table F2. Anteroposterior diameters of alveoli

[In millimeters]

\begin{tabular}{lrrrrrrrrrr}
\hline Alveolus & 1 & 2 & 3 & 4 & 5 & 6 & 7 & 8 & 9 & 10 \\
\hline $33-$ CR-9 ........ & 9 & 7 & 9 & 12 & 8 & 9 & & & & \\
$137-$ CR-1 ....... & & 13 & 10 & 11 & & & & & & \\
$58-C R-1 \ldots \ldots \ldots$. & & & & & 9.5 & 6 & 9.5 & 11 & 9.5 & 9 \\
$37-C R-10 \ldots \ldots \ldots$. & 7.5 & 6 & 6.7 & 8.5 & & & & & & \\
$37-C R-7 \ldots \ldots \ldots$. & 16 & 10 & & & & & & & & \\
\hline
\end{tabular}

\footnotetext{
'The tip of this rostrum may be pathologically deformed and the second alveoli appear somewhat hypertrophied.
}

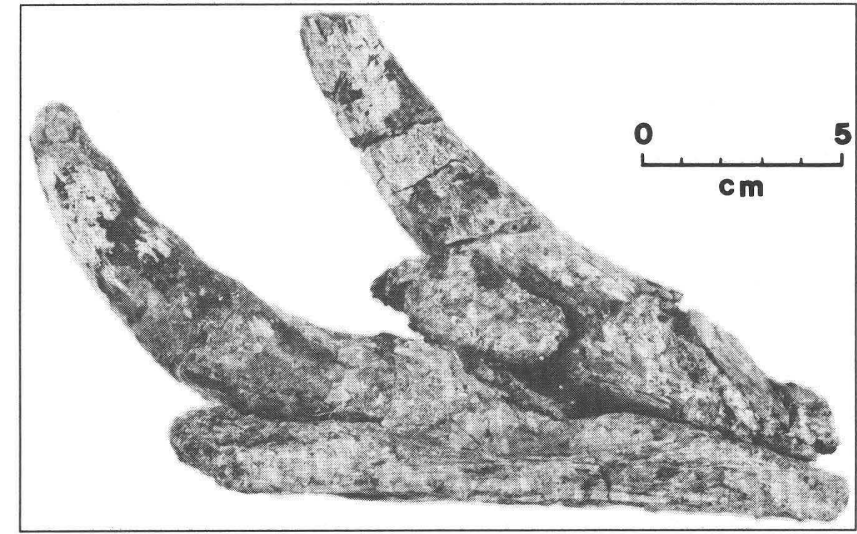

Figure F12. Rhabdognathus sp., no. 37-CR-1. First and second mandibular teeth showing recumbency and overlapping roots.

vertebrae, but it is not certain that the last vertebra preserved is the last presacral. Troxell (1925) reported 22 presacral vertebrae in a disarticulated skeleton of Hyposaurus natator, but he believed that some elements were missing. Swinton (1950) described selected vertebrae of $H$. bequaerti from an incomplete series, and Buffetaut (1980) has discussed regional variations in the column of Dyrosaurus from a functional point of view.

Most of the vertebral column of no. 37-CR-1 was found articulated, and I believe that all presacrals are represented. There is evidence for 25 vertebrae, but what is probably the ninth postcranial vertebra is very fragmentary and the third vertebra in front of the sacrum is represented only by the tip of a transverse process. Neural spines and zygopophyses are usually separated from their respective centra in this and other specimens in the collection, owing to loss of the more delicate parts of the neural arches. It has been possible, however, to reestablish contact between many of the transverse processes and their respective arches.

Lacking ribs, it is impossible to recognize the first thoracic vertebra in most crocodilians because the morphological changes between cervical and thoracic vertebrae are gradual. The eighth postcranial vertebra in no. 37-CR-1, however, bears a robust diapophysis confined to the side of the pedicle, the parapophysis is a distinct backwardly projecting process arising near the middle of the centrum. I take this to be the first thoracic. 


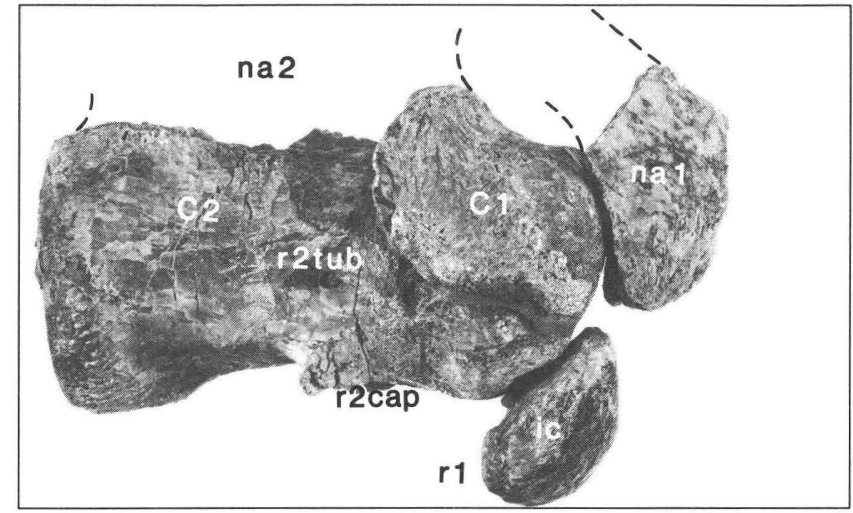

Figure F13. Rhabdognathus sp., no. 37-CR-1. Atlas and axis, right lateral view. $\mathrm{C} 1$, na1, ic, centrum, neural arch and intercentrum, respectively, of atlas; $\mathrm{C} 2$, na2, centrum and neural arch (broken off) of axis; r1, facet for first rib; r2 cap, capitular facet for second rib; $\mathrm{r} 2$ tub, facet for tuberculum of second rib.

There are probably three lumbar vertebrae. The first of these bears a winglike transverse process without any rib articulation, whereas the first well-preserved vertebra anterior to this has stronger transverse processes that clearly bore ribs. Among the associated fragments is the end of a transverse process that seems intermediate in shape between that of the lumbars and the rib-bearing thoracics; this probably represents the middle lumbar because a gap is clearly present between the other two lumbars preserved. If my interpretation is correct, the vertebral count for Rhabdognathus sp. is C-8, T-14, L-3, S-2. The first 6 caudal vertebrae were found articulated in no. 37-CR-1, and 15 others were collected with the specimen. Obvious gaps exist, however, and the total number of caudals in the dyrosaur tail remains unknown.

The atlas-axis complex of Hyposaurus bequaerti has been described, but not figured, by Swinton (1950). Troxell (1925) describes the central structures in $H$. natator, and provides a small illustration. Parris (1986) figures the proatlas of $H$. rogersii. The atlas-axis complex is present in no. 37-CR-1 (fig. F13), and the atlas and axis pleurocentra are preserved in no. 58-CR-1. Other atlas and axis centra are present in the collection, but no neural arches are preserved.

The intercentrum and the anterior part of the pleurocentrum of the atlas show every sign of having been embedded in cartilage. A deep, round notochordal pit is seen near the top of the anterior surface of the intercentrum. Correlated with a relatively huge occipital condyle, the atlantal pleurocentrum appears more massive in relation to the axial pleurocentrum than in extant crocodilians-its greatest transverse diameter (anterior) exceeds that of the axis (posterior) by about 30 percent. The pleurocentra of the atlas and axis are suturally united, as described in $H$. natator. In no. 58-CR-1 these bones have separated, revealing wellformed opposing tongue-and-groove surfaces (fig. F14).

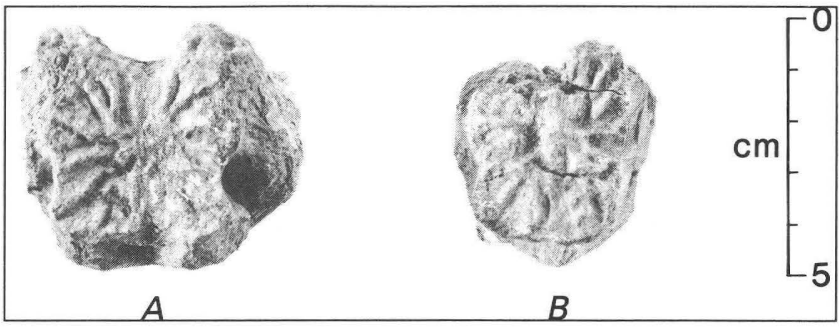

Figure F14. Rhabdognathus sp., no. 58-CR-1. Opposing articular ends of the atlantal and axial centra. $A$, posterior end of atlas; $B$, anterior end of axis.

Specimen no. 58-CR-1 is only a little smaller than no. 37-CR-1 where the bones are united, so their separation in no. 58-CR-1 may be owing to fortuitous preservation or individual variation. The atlas pleurocentrum is a blocky structure with a roughly equilateral wedge-shaped lateral profile. Its superior surface is largely occupied by the flat bottom of the neural canal. The canal narrows rapidly posteriorly where the dorso-lateral edges of the centrum are expanded to receive the anterior ends of the neural arch pedicles of the axis. Laterally, above midheight of the pleurocentrum, the robust diapophysis for the axial rib projects backward and downward as a discrete process. It is separated from the pleurocentrum distally by a deep pleurocentral depression that also separates the diapophysis from the ventro-lateral parapophysis below. The articular surface of the parapophysis is concave in ventral profile and is about twice as long as it is high. More than half of this parapophysis is on the pleurocentrum of the axis. Its posterior edge stands out sharply from the ventrolateral edge of the axis intercentrum.

The anterior face of the atlantal pleurocentrum is concave, and, with the neural demi-arches and the atlantal intercentrum, forms a deep, transversely oval cup for the occipital condyle. The right demi-arch is preserved in no. 37-CR-1, but its superior process and postzygapophysis have been broken off. It is mainly a wedge-shaped block excavated above by the neural canal. It appears to have been lower than the corresponding arch in existing crocodilians.

The pleurocentrum of the axis is sharply truncated anteriorly where it joins the pleurocentrum of the atlas and is much wider posteriorly than in front. Anteriorly, its sides are almost vertical and its bottom is flat. A system of strong ridges is developed on the ventral surface (fig. F15). A low tuberous hypapophysis occurs near the posterior end and extends forward for about one-third of the length of the pleurocentrum. A hypophyseal ridge, reported in $H$. 


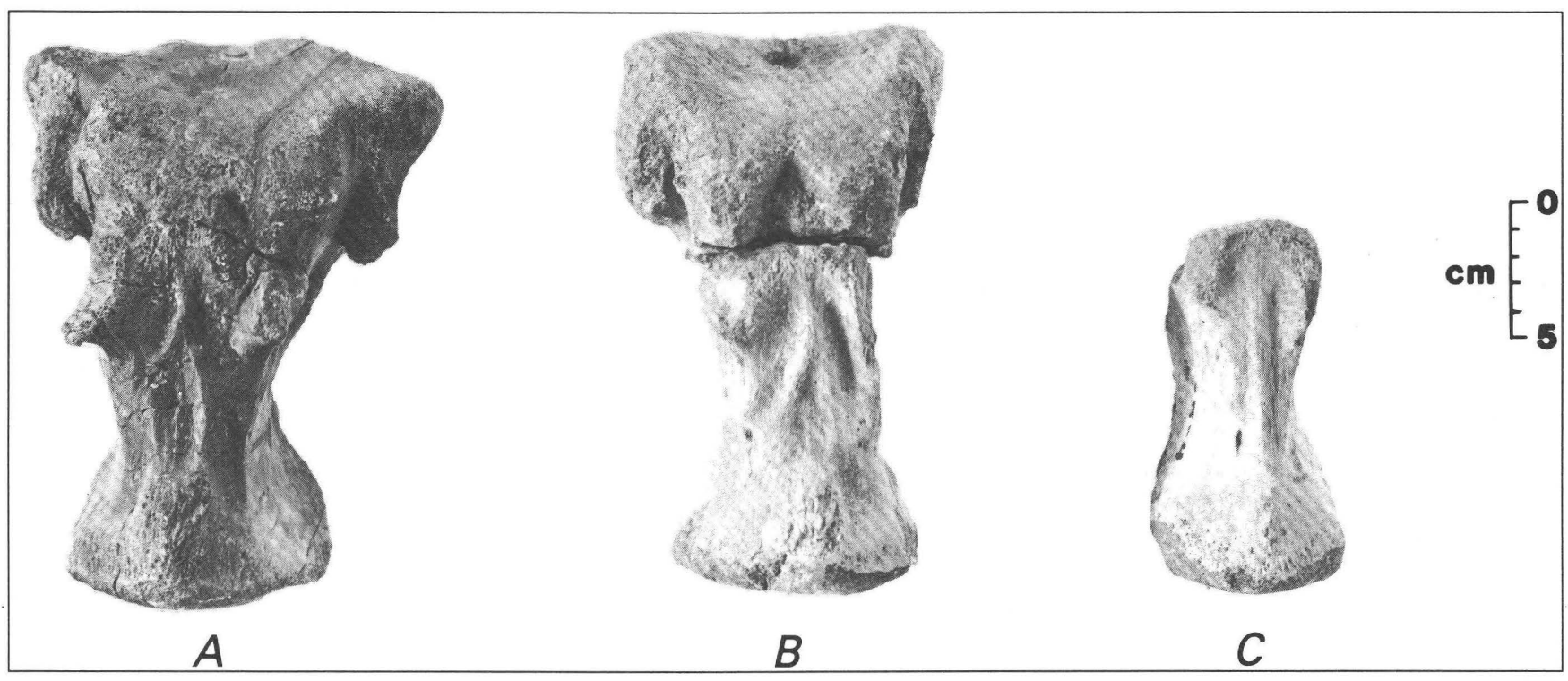

Figure F15. Rhabdognathus sp. Variation in the ventral ridge system on axial vertebrae. $A$, no. 37-CR-1; $B$, no. 58-CR-1; $C$, no. 3-CR-4.

Table F3. Measurements of atlas-axis

[In millimeters]

37-CR-1 58-CR-1

\section{Atlas}

Transverse diameter, dorsally, of intercentrum 44

Transverse diameter, ventrally, of intercentrum 27

Height of intercentrum

Length of intercentrum

18

Transverse diameter, dorsally, of anterior end of 74 pleurocentrum

Height of anterior end of pleurocentrum

Length, dorsally, of pleurocentrum

Height of posterior end of pleurocentrum

\begin{tabular}{|c|}
\hline 45 \\
\hline 40 \\
\hline 47 \\
\hline
\end{tabular}

Axis

Transverse diameter, dorsally, of posterior end of 47 pleurocentrum

Height, posterior end of pleurocentrum 46

Least transverse diameter of pleurocentrum $\quad 26$

Length of pleurocentrum

Greatest length of atlas-axis complex
44

45

28

60 10194

bequaerti by Swinton (1950), is not present in either no. 37-CR-1 or 58-CR-1 where the hypapophyseal tuberosity is bounded anteriorly by a median triangular depression. A median ridge is present, however, in a detached pleurocentrum (no. 3-CR-1). The posterior end of the pleurocentrum is amphiplatyan, with a shallow central excavation surrounded by a thickened discoid rim that occupies about onequarter of the surface. The floor of the neural canal is greatly constricted at midlength, but it flares out posteriorly,

reflecting the configuration of the pleurocentrum. At midlength, the bottom of the canal is pierced by paired longitudinally oval foramina.

Swinton (1950, p. 19) describes the axis neural arch of $H$. bequaerti as being low anteriorly, but rising posteriorly, "...though the spine itself is nowhere high." For measurements of the atlas and axis see table F3.

Platycoelous centra are the most frequently found dyrosaurian remains. Several authors have noted the wedgeshaped lateral profile in which the cervical centra are longer at the bottom than above (table F4). The difference is particularly noticeable in the seventh cervical of no. 37-CR-1. The dimensions are about equal in the anterior thoracic vertebrae, but farther back the ventral edge becomes shorter than the dorsal edge (fig. F16). In the anterior caudals the dimensions are again about equal, but from the middle of the tail backward the wedging downward condition reappears and increases in the more distal vertebrae. One such centrum is $52 \mathrm{~mm}$ long ventrally and $55 \mathrm{~mm}$ long dorsally.

The sides of the cervical centra are excavated between the dia- and parapophyses. These pleurocentrous depressions are absent in the anterior thoracic vertebrae, but they reappear at about thoracic number 9 and thence become progressively larger back to the last lumbar. Here the depression is about the size of the end of one's thumb and is shared about equally by the centrum and the neural arch.

The ends of the centra consist of a thickened peripheral disc surrounding a central depression (figs. F16, F18). The thickness of the disc is greatest at the bottom of the centrum, and the central depression is deepest on the posterior face. The area of the disc may be as much as two-thirds of the area of the distal end in some anterior caudals. The exterior of the bone near the edges of the central disc is marked by many short parallel longitudinal ridges. 
Table F4. Measurements of vertebrae, specimen no. 37-CR-1

[In millimeters]

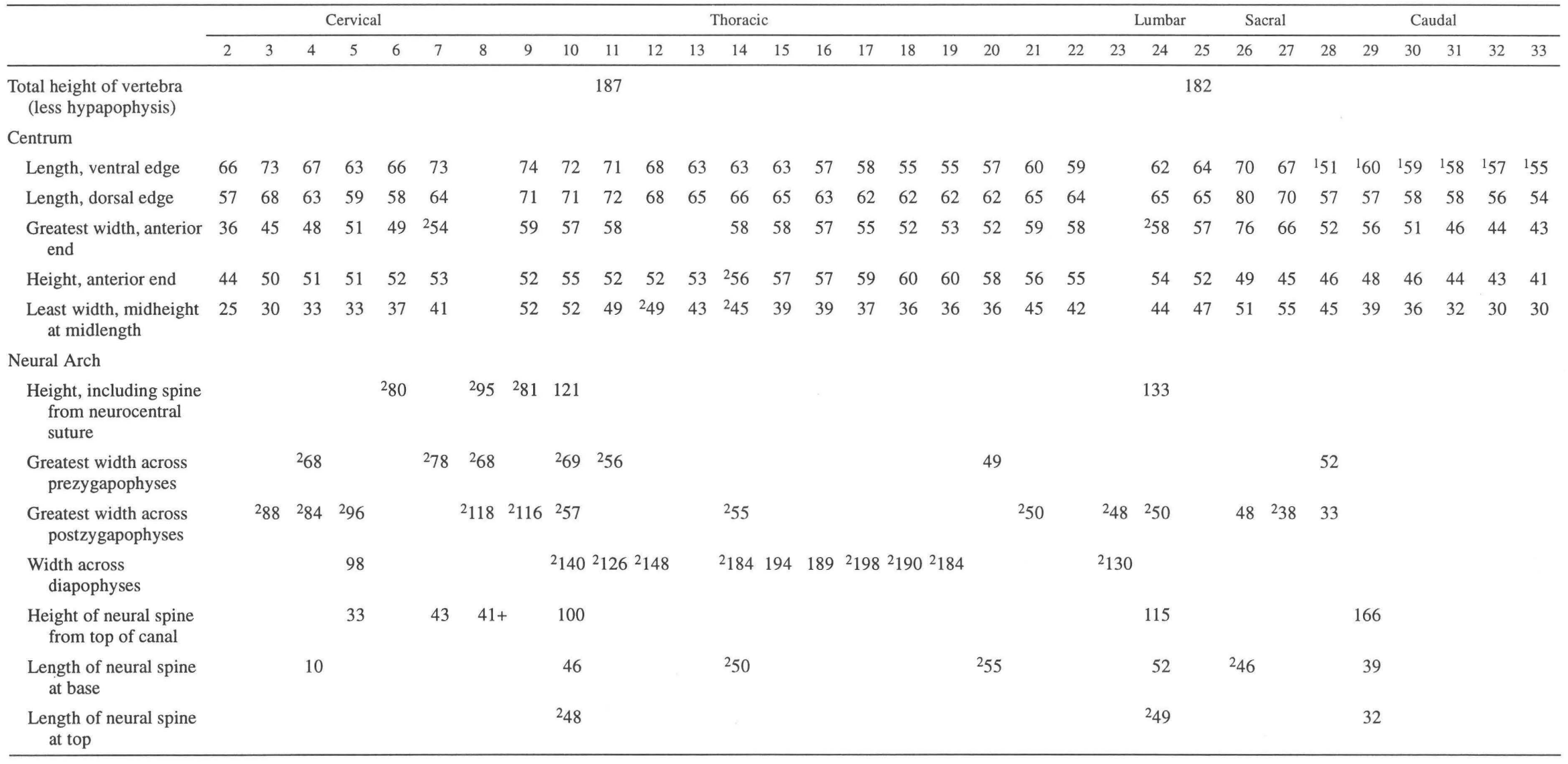

${ }^{1}$ In caudals greatest length toward bottom of centrum is used to avoid chevron facets.

${ }^{2}$ Estimates are given only when small pieces are missing. 


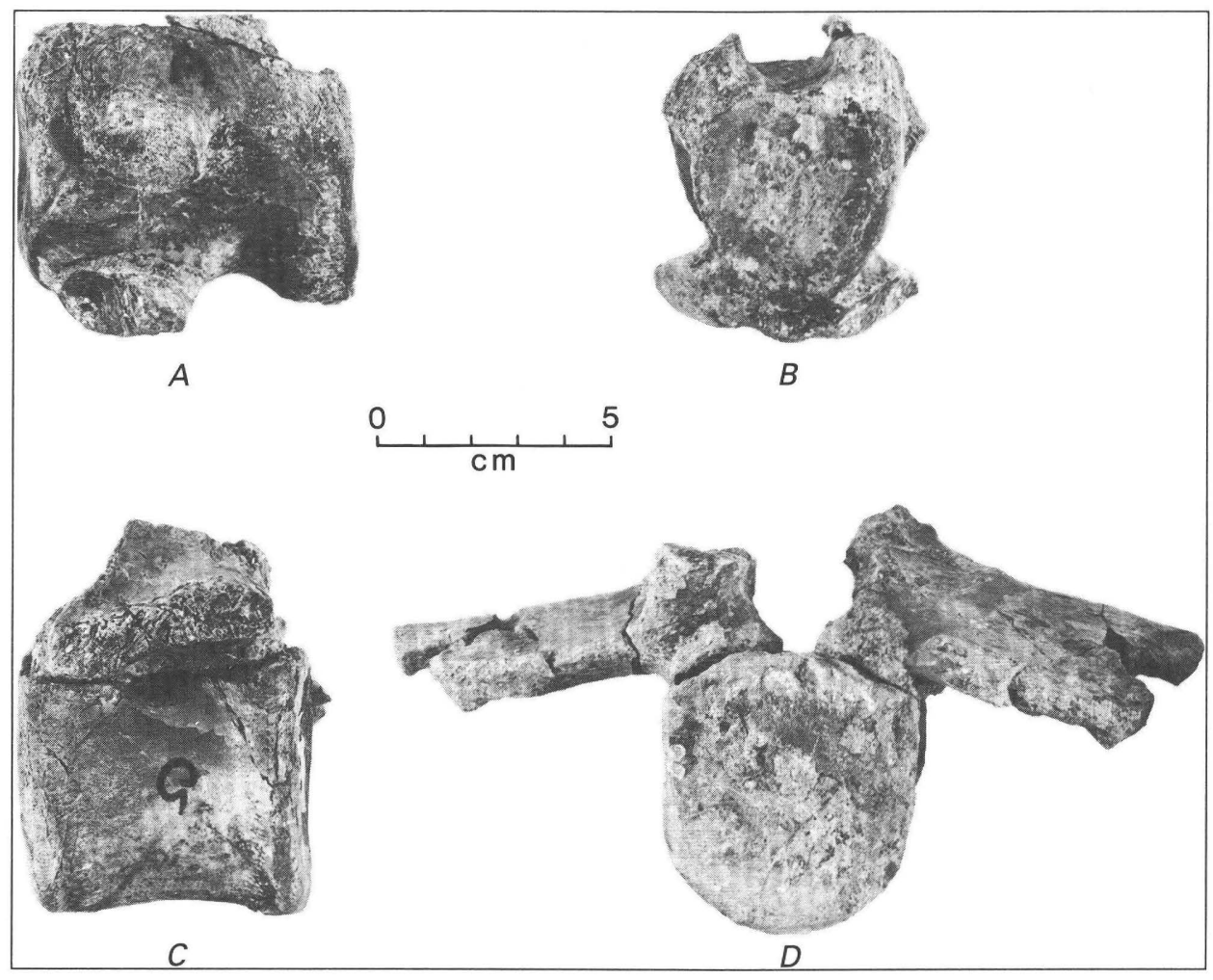

Figure F16. Rhabdognathus sp., no. 37-CR-1. A, centrum of the 3 rd cervical vertebra, left lateral aspect; $B$, the same, posterior aspect; $C$, incomplete 12th thoracic vertebra, left lateral aspect; $D, 9$ th thoracic vertebra, anterior aspect.

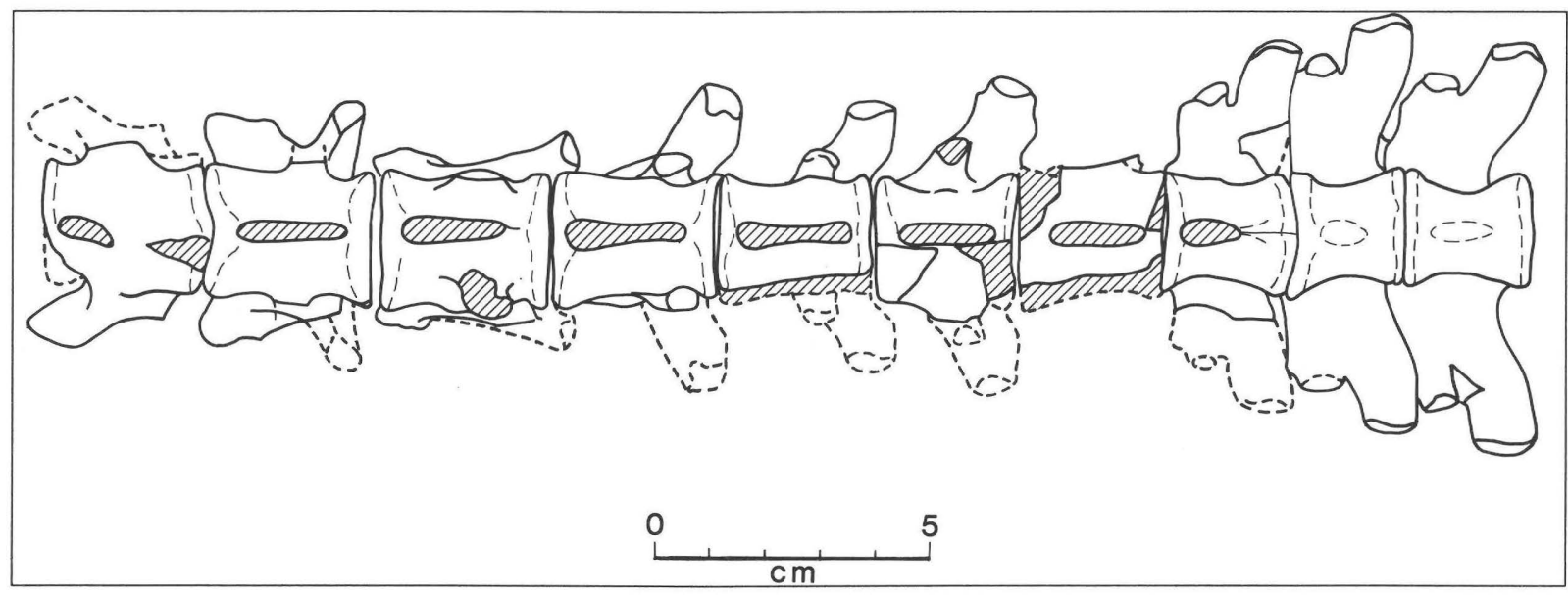

Figure F17. Rhabdognathus sp., no. 37-CR-1. Articulated 7 th cervical to 9 th thoracic vertebrae, ventral aspect, showing extent of hypapophyses (anterior is to the left). All hypapophyses are broken off at the base except those of thoracics

Caudal centra are distinctive in their square-cut, boxlike proportions, noted by Swinton (1950). It was such vertebrae, from the Eocene of Nigeria that Nopcsa (1925) mistook for hadrosaurian caudals. Widely beveled edges for insertion of chevrons appear first on the posterior ends of the second and third caudal centra. Beveling and the formation of facets first takes place on the fourth centrum, and continues posteriorly into the distal caudals.
8 and 9 , which are represented only by slight swellings in the ventral midline. Hypapophysis of the 7 th cervical is deformed and the right diapophysis is underdeveloped in this vertebra.

Hypapophyses - the root of the name Hyposaurus (Owen, 1849) - are more strongly developed in dyrosaurs than in any other group of crocodilians. Interestingly, however, as in other marine mesosuchians, the processes are less developed in the cervicals than they are in eusuchian crocodiles (fig. F17). In no. 37-CR-1 only low tuberosities are present at the posterior end of the axis, anteriorly and posteriorly on cervicals 3 and 4, and are virtually lacking on cervicals 5 and 6. Judging from its broken base, which 
extends about one-third of the length of the centrum, the first strong hypapophysis occurs at the anterior end of cervical 7. This is apparently one vertebra earlier than in the articulated series described by Storrs (1986). From here posteriorly to the fourth thoracic vertebra, the processes extend almost the full length of their respective centra. The centrum of the fourth thoracic is $51 \mathrm{~mm}$ long at its base. But then, in the sixth and seventh, the basal lengths decrease, and in the eighth thoracic, one later than in Storrs' specimen, the hypapophysis reverts to a small tuberosity about $23 \mathrm{~mm}$ long on the anterior third of the centrum. The remaining presacral vertebrae lack ventral projections and the bottoms of the centra become transversely angular, producing the ogival cross section noted by Arambourg (1952).

Troxell (1925) reported a moderate ventral keel on what he believed to be the sixth cervical vertebra in Hyposaurus natator. Keels are said to be present in the vicinity of the last cervical and the following four or five thoracic centra, with the hypapophyses increasing in size posteriorly. On the fifth thoracic the process is prominent and extends nearly the length of the centrum, but the hypapophysis is suddenly reduced to only half the length of the centrum on the sixth. Apparently hypapophyses do not exist posterior to the sixth thoracic vertebra in $H$. natator. This sequence agrees reasonably well with that of Rhabdognathus sp. and tends to confirm Troxell's arrangement of the incomplete vertebral column in $H$. natator.

The hypapophysis of the atlas is described as a slight ridge in $H$. bequaerti, that on the preserved fifth or sixth cervical as "slight... a little in advance of the middle length" (Swinton, 1950, p. 20). The conditions described by Swinton in the ?fourth dorsal and a middorsal are comparable to those in no. 37-CR-1.

Noting the crosslike impression of neurocentral surfaces, Thevenin (1911) was impressed by the lack of fusion between the neural arches and the centra in Dyrosaurus phosphaticus. This is now known to be the normal state in marine mesosuchians, including large dyrosaurs. Even the biggest centra in the Saudi Arabian collection have thus become separated from their arches. Only in the caudals does the neural arch regularly fuse with the centrum, a tendency shared with eusuchian crocodilians. The pedicles are long throughout the column and are broadly attached to the centra except in the caudals where their sides are thinwalled. The neural canal is wider than high and is largest in the anterior part of the column, but the difference is not great. The pedicles are more deeply notched posteriorly than anteriorly, where the prezygapophyses restrict the intervertebral channels.

Diapophyses and parapophyses are robust, especially on the cervicals and anterior thoracic vertebrae. Diapophyses spring from the centrum in the anterior cervicals, but in the fifth cervical a little more than half of the process is borne by the neural arch (it is near this vertebra that the resemblance of the neuro-central surface to that of Champ- sosaurus and nothosaurs, noted by early workers, is most striking). The parapophyses arise close to the ventral edges of the centra on the cervicals. They project outward, forward, and downward below the general plane of the bottom of the centra in the anterior vertebrae, rising a little above the baseline in the last two cervicals. There follows in the first thoracic an abrupt shift upward in the position of the parapophysis, to mid-height of the centrum. This shift is more pronounced than in Crocodylus. On the third thoracic, the parapophysis is partly divided by the neurocentral suture, and on the fifth it is almost completely transferred to the neural arch. On the eighth, the parapophysis lies almost in the same plane as the diapophysis, and this relationship is maintained caudad to the end of the series.

The diapophysis is completely on the side of the arch in the first thoracic vertebra. In the anterior part of the column these processes project outward, downward, and slightly forward, but on the first thoracic vertebra the diapophysis slants backward and only a little downward. The backward slant increases through thoracics $2-5$, but with number 7 , an angle of about 90 degrees to the sagittal plane is achieved and is maintained throughout the rest of the series.

Where united dia- and parapophyses form a transverse process, from thoracic 7 to 13 , this is broad and platelike. When these vertebrae are articulated, the space between succeeding transverse processes is only about $5 \mathrm{~mm}$. During dorsal or lateral flexion of the trunk, contact between adjacent processes is avoided because their planes are inclined a few degrees forward, so the trailing edge (diapophysis) always is higher than the leading edge (parapophysis) of the succeeding vertebra. The transverse processes seem remarkably short, the greatest transverse diameter across any of them being about $198 \mathrm{~mm}$, on thoracic number 10 . Transverse processes on the lumbar vertebrae are broad and blade-like and are roughly horizontal.

Transverse processes are absent on the anterior caudals, where ribs are inserted into facets on the sides of the centra and neural arches. The most posterior caudal centrum preserved in no. 37-CR-1 has a sharp longitudinal ridge in place of the caudal rib.

The zygapophyses seem less robust than in existing crocodilians. Toward the back of the neck, the angle between opposite articular faces is more acute than in Crocodylus acutus, for example. The processes are largest and most widely spread in the cervical-thoracic transition. They diminish in size from the first thoracic posteriorly. The articular surfaces are less expanded than in the posterior thoracic and lumbar vertebrae of existing crocodilians. The prezygapophyses in the posterior part of the trunk are inclined at an angle of only about 53 degrees to the sagittal plane, compared to a corresponding angle of 70 degrees in Alligator mississippiensis. Zygapophyses are not present in the distal caudals, but at what point they disappear is unknown. What remains of some neural arches, however, 


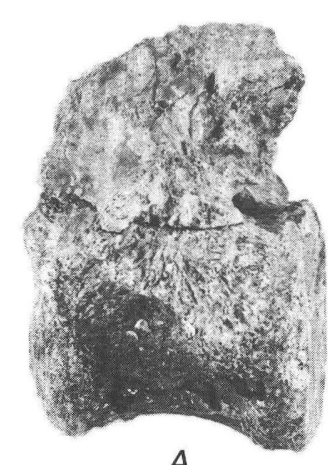

$A$

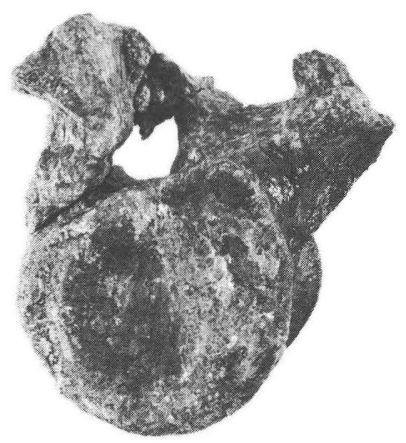

$D$

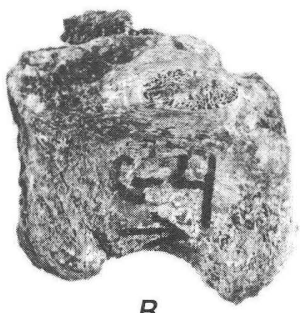

$B$

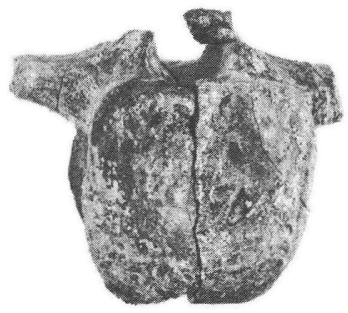

$E$
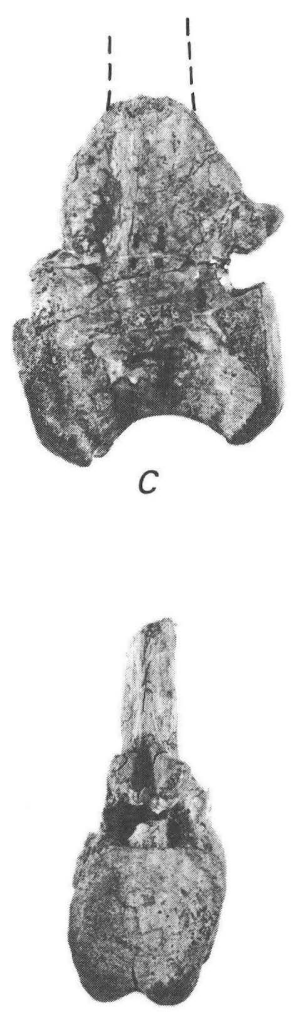

$F$

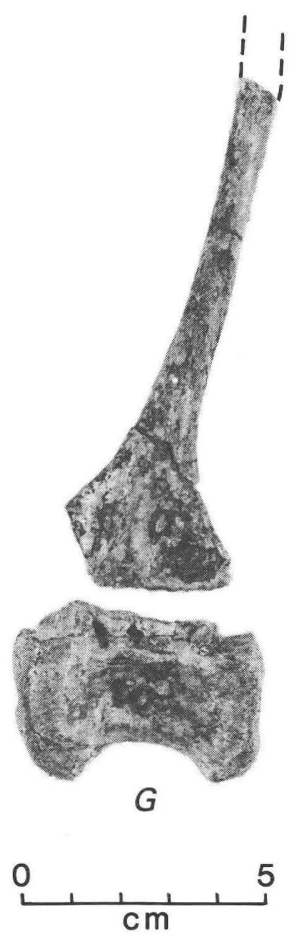

Figure F18. Rhabdognathus sp., no. 37-CR-1. Caudal vertebrae. $A$, first; $B$, fifth; $C$, medial centra, left lateral aspect; $D-F$, the same, posterior aspect; $G$, distal caudal centrum and neural spine.

suggests that prezygapophyses remain for a while after contact with their opposing postzygapophysis has been lost.

Although most of the spines in the presacral column appear to be represented in no. 37-CR-1, only the first and third thoracic and third lumbar spines are attached to their respective vertebrae. The anterior presacral spines were evidently similar to those figured for $H$. natator (Troxell, 1925, fig. 4) and for D. paucidens (Arambourg, 1952, fig. 60). The anterior cervical spines were low and triangular in lateral profile. The fifth or sixth cervical spine is bent slightly backward with the leading edge exceeding the trailing edge somewhat in length. The anterior thoracic spines were probably higher, wide and inclined backward as described in $H$. natator and $H$. bequaerti, but the best preserved spine, that of the third thoracic vertebra, is more upright and the leading edge is straighter than in the so-called eighth vertebra of $H$. natator figured by Troxell (1925, fig. 4C). The spine of the 3 rd lumbar vertebra is, however, much higher in relation to the length of the centrum than in the approximately 15th vertebra figured by Troxell (1925, fig. $4 D$ ). The height of the caudal spines is most remarkable. Swinton (1950) figures an anterior caudal of $H$. bequaerti in which the spine is five times as high as its centrum. The spine associated with caudal 4 in no. 37-CR-1 is a little more than three times the height of its centrum. The spine of a posterior caudal which corresponds in shape to the "late" caudal figured by Swin- ton $(1950, \mathrm{pl} .8 B)$ has a rodlike spine which, when complete, was probably similar to that of $H$. bequaerti. The main part of the spine is a pencillike rod with a thin median lamina on the anterior and posterior edges near its base (fig. $\mathrm{F} 18 \mathrm{G}$ ). The posterior lamina divides downward to form the postzygapophyses, but the forward lamina ends below in the roof of the neural canal. Retention of these extremely long slender neural spines far distally in the tail is unique to the dyrosaurs.

The sacral centra were apparently separated by a thin cartilage disc. The anterior articular face of the first sacral is almost round, but the sacral rib heads are expanded anteriorly and are inserted into posterolateral facets on the last lumbar centrum. This greatly increases the transverse articulating surface of the first sacral so that while it is $50 \mathrm{~mm}$ high, it is about $80 \mathrm{~mm}$ wide. A similar arrangement exists between the second sacral and the first caudal, with the sacral centrum having principal diameters of $46 \mathrm{~mm}$ high and about $56 \mathrm{~mm}$ wide. The intersacral articular surface is transversely oval. The bottoms of the centra are broadly rounded transversely, that of the first bearing a low rounded median ridge.

The detached neural arch of the second sacral is partly preserved in no. 37-CR-1. As in eusuchians, the prezygapophyses are slender and closer together than those of the lumbar vertebrae, and, contrary to conditions in the trunk 
vertebrae, their articular surfaces are horizontal and slightly concave along the axis of articulation. Postzygapophyses are larger but are closer together and their articular surfaces are somewhat more steeply inclined than in Crocodylus.

The spinal column of no. 58-CR-1 was partly articulated. Present are 7 cervicals, 14 thoracics, 2 lumbars, 1 sacral and 9 caudals. I find no significant differences between these vertebrae and those of no. 37-CR-1; however, the hypapophyseal tuberosity is less developed on the seventh thoracic centrum, and the bottoms of the succeeding centra seem a little more angular than in no. 37-CR-1.

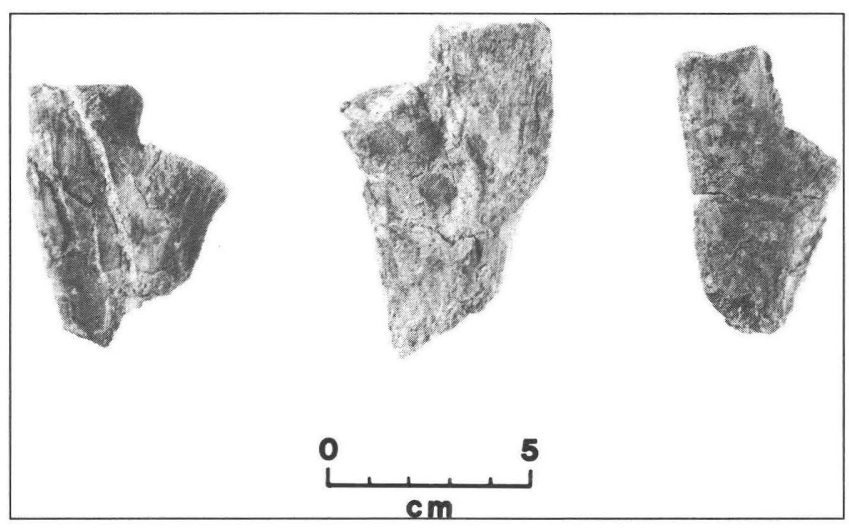

Figure F19. Rhabdognathus sp., no. 37-CR-1. Proximal ends of thoracic ribs.
Ribs.-Except for two cervical ribs, only fragments of ribs are available. One cervical rib (no. 33-CR-1) is not significantly different from midcervical ribs in Crocodylus, but it seems a little more robust. Judging from the disposition of the dia- and parapophyses, the last rib with a bifurcated head occurred at about the fourth thoracic vertebra. When the tubercular and capitular processes coalesce, the resulting rib head appears broader than in eusuchians and, as would be expected from the short transverse processes, the capitular process is much abbreviated (fig. F19). There is no evidence of uncinate processes. The thoracic ribs are expanded distally as in existing crocodilians.

It is clear from the attachment surfaces on the atlas intercentrum that the first cervical rib was single headed as in all mesosuchian and eusuchian crocodiles. Its head must have been largely imbedded in the cartilage that surrounded the atlas as no distinct facets are developed. The second cervical rib was double headed and, to judge from the strength of the diapophysis on the atlantal pleurocentrum, both the capitular and tubercular processes were much better developed than in existing crocodilians, where the tubercular articulation is often ligamentous (Wettstein, 1937). Indeed, I can find no example among mesosuchians or eusuchians in which the atlantal diapophysis is so strong as in no. 37-CR-1.

The sacral ribs appear almost as mirror images of one another from above, except that the second rib is smaller than the first (fig. F20). Their heads are firmly inserted into

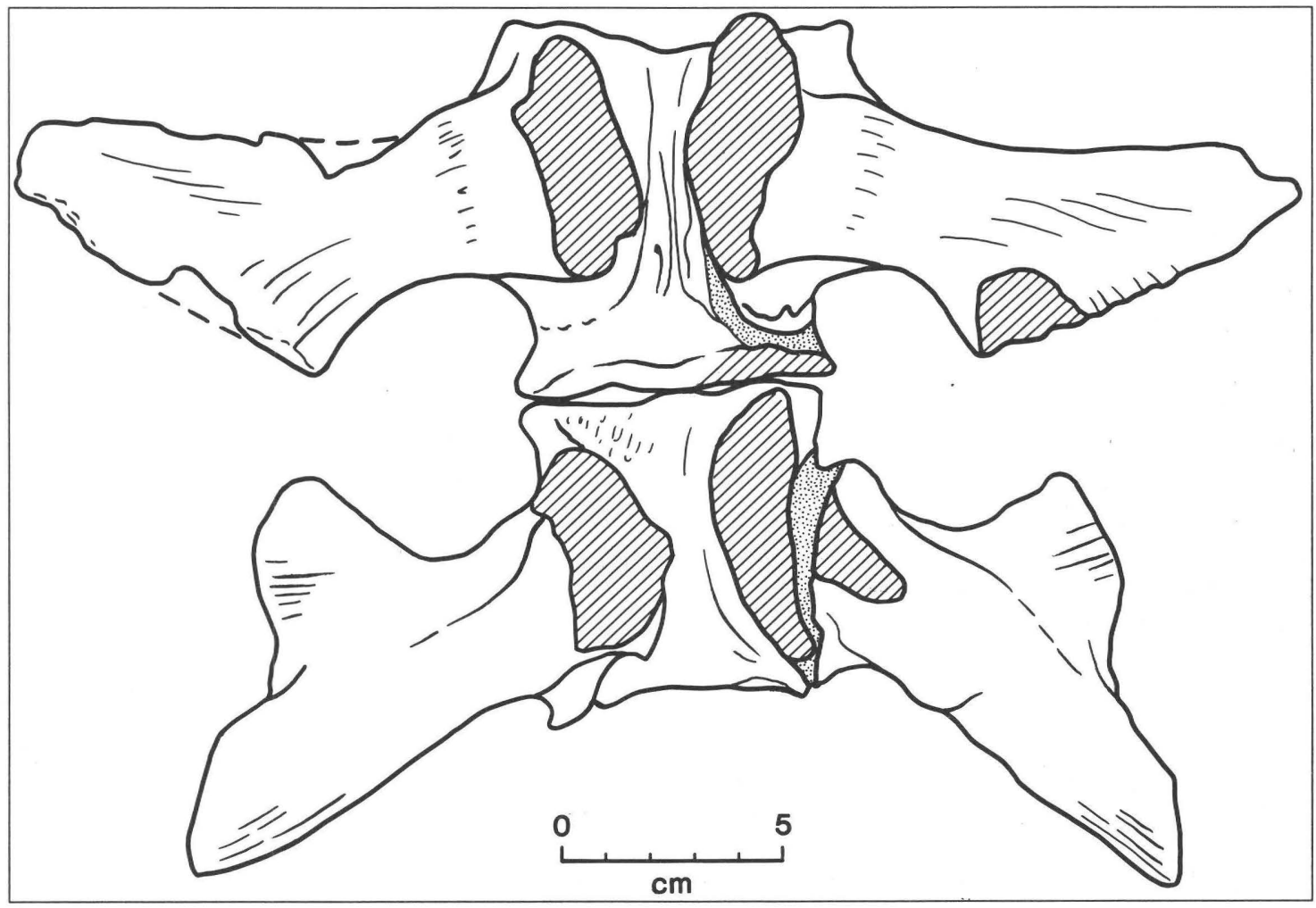

Figure F20. Rhabdognathus sp., no. 37-CR-1. Sacral vertebrae and ribs, dorsal aspect. Anterior at top. 


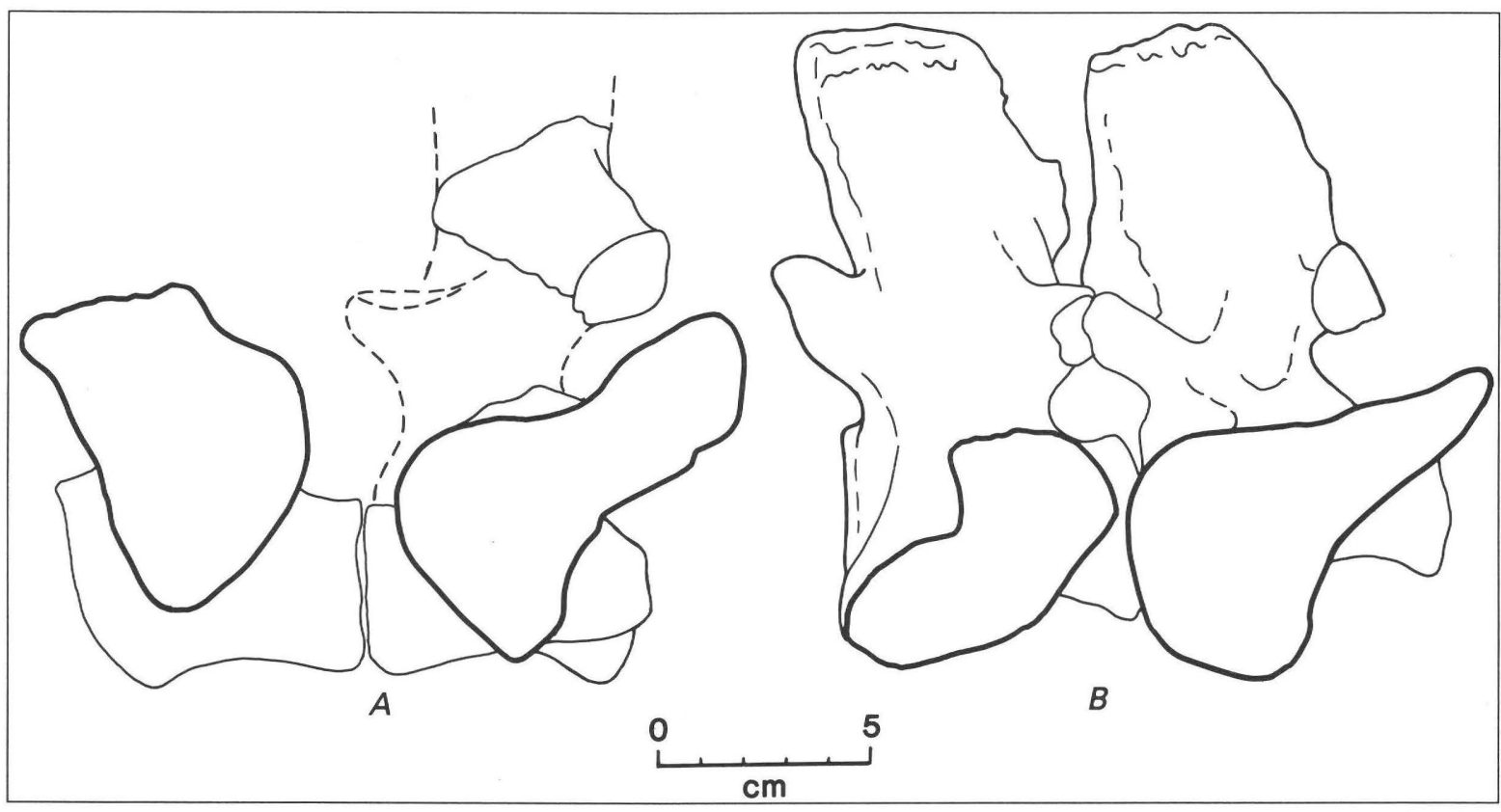

Figure F21. Dyrosaur and eusuchian sacra, left lateral aspect. A, Rhabdognathus sp., no. 37-CR-1; $B$, Crocodylus acutus, drawn to the same scale to contrast shapes of the first sacral ribs. Position of neural arch in $A$ is conjectural.

sockets on the sides of the centra and the neural arch pedicles. Nevertheless, the bones readily separated in most specimens after death. The first sacral rib is distinctively different from that of Crocodylus; its iliac end is roughly triangular, with its antero-dorsal corner projecting both anteriorly and laterally far out beyond the level of its ventral angle (fig. F21). The iliac surface of the second rib resembles that of Crocodylus. The anterior part of the articular surface is convex and was inserted into a corresponding excavation on the medial side of the ilium. The rib end is drawn out posterodorsally into a long process whose iliac surface is broadly excavated. This excavation received a correspondingly rounded diagonal ridge of the ilium.

Caudal ribs, best seen in no. 37-CR-1, are thick and wide. Their heads occupy almost the full length of the centrum in the anterior caudals. They are suturally attached to excavations in the sides of the centrum and neural arch. The last vestiges of the suture are seen in the fourth caudal, after which the ribs appear as transverse processes. No caudal rib or transverse process is complete, but the thickness of the bases of the anterior ribs suggests that these structures were of substantial size as far back as the midcaudals.

Haemapophyses.-Several fairly complete haemapophyses are preserved in no. 37-CR-1 (fig. F22). What is probably the second chevron is slender and tapers to a point distally. It possesses vertebral facets only on the posterior side of the arch. This chevron, lacking the distal tip, is 150 $\mathrm{mm}$ long. The haemal canal has principal maximum diameters of 33 and $9 \mathrm{~mm}$. Farther down the tail the chevrons become shorter and broader, flaring out distally into an asymmetrical spatulate blade. All chevrons preserved have the haemal canals closed above, but in at least some the two halves of the arch are not coalesced. Proximal ends of the arches are robust and, except for the first few chevrons, have well-developed facets both fore and aft. Viewed from the side, the broadly triangular proximal ends are inserted into the correspondingly wide intervertebral spaces. In the more distal chevrons the distal end becomes paddle shaped. One such bone from no. 37-CR-1 is $70+\mathrm{mm}$ high with anteroposterior diameters at the top, midheight, and bottom of 24,13 , and $27 \mathrm{~mm}$, respectively. Far distal chevrons are not represented, and it is not known at what position chevrons disappear.

Gastralia.-One almost complete gastral rib was found with no. 58-CR-1. It is thick and on one side, presumably posterior, displays two deep grooves. I believe it is the lateral segment of the last gastral rib and the larger of the two grooves lodged the anterior cartilaginous edge of the pubis. The second, smaller, and more medial groove received the posterolateral end of the medial segment of the rib. The thickest part of the bone occurs in the short space between the opposing ends of the two grooves. Here its maximum diameter is $9.5 \mathrm{~mm}$. The preserved segment, lacking both ends, is $134 \mathrm{~mm}$ long.

Pectoral arch.-The pectoral arch of dyrosaurs is impressively massive and is relatively much larger and better ossified than in the other marine mesosuchians. The scapula and coracoid display some unique features.

No complete pectoral elements are available in the Saudi Arabian collection. Either a badly weathered proxi- 


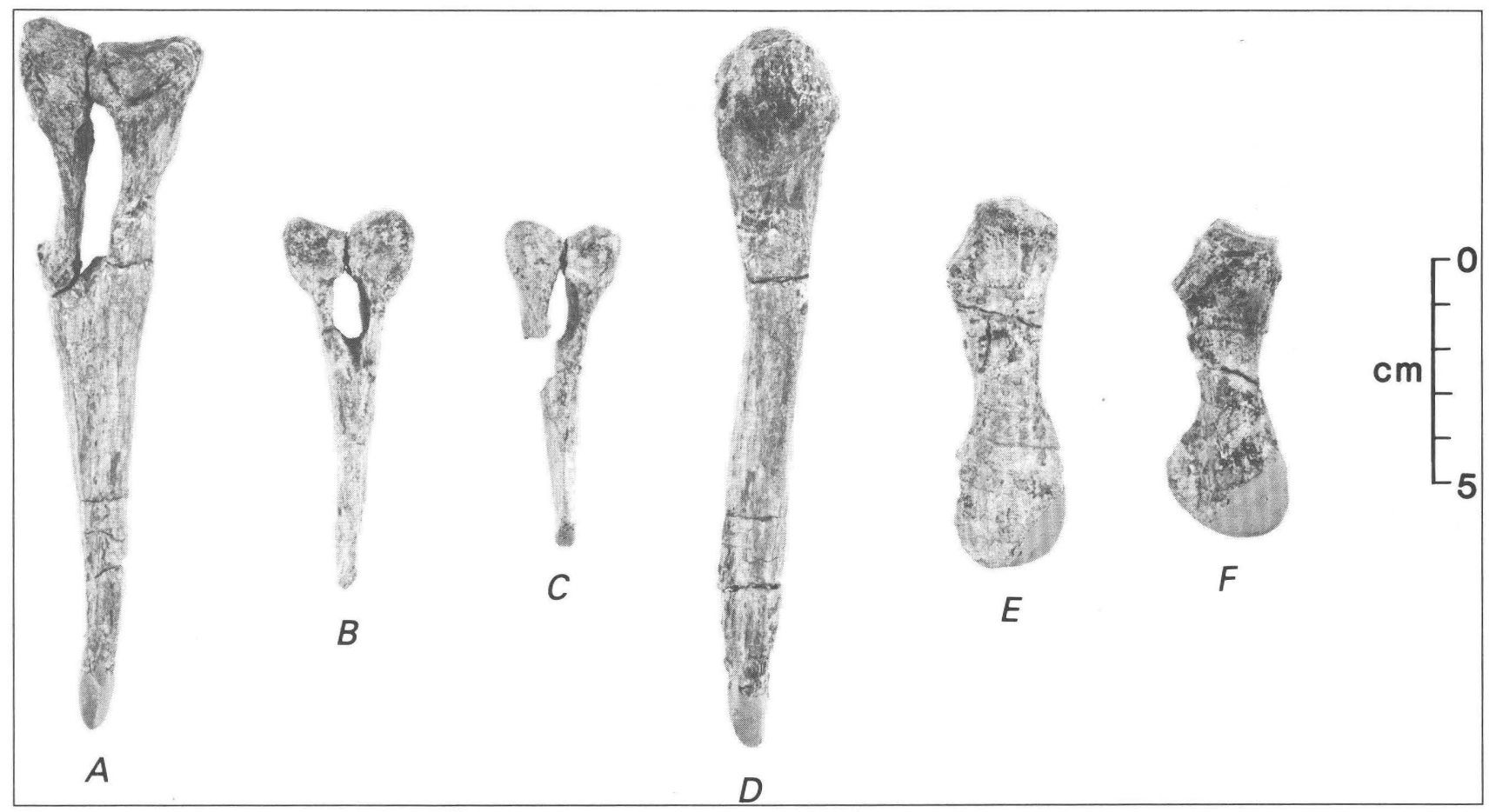

Figure F22. Rhabdognathus sp., no. 37-CR-1. Haemapophyses. A, proximal, possibly second chevron; $B$, mid-caudal chevron; $C$, distal mid-caudal chevron, posterior aspect; $D-F$, the same, right lateral aspect.

mal end of a large scapula (no. 37-CR-3) or a slightly smaller proximal end of a coracoid (no. 37-CR-2) may belong to the skeleton no. 37-CR-1. Better preserved, but probably too small to belong to no. 37-CR-1, is the proximal end of a left scapula (no. 37-CR-4). The proximal end of a very small left scapula (no. 37-CR-5) is also present. A left coracoid (no. 37E-CR-1) lacks only the anteroproximal lobe. Also present is the sternal end of a larger coracoid (no. 36W-CR-1), and a fragment of a proximal end (no. 2-CR-1).

The coracoid (no. 37E-CR-1) resembles that of $H$. natator and confirms Troxell's reconstruction (fig. F23A). It is also similar to the coracoid of $H$. bequaerti. It is much more slender, has a straighter shaft, and the distal end is less expanded than in eusuchians. When oriented in life position, the shaft projects posteromedially and, curving away from the glenoid cavity, becomes almost recumbent distally. Seen from the side (fig. F23B), less of the coracoid is visible than in existing crocodiles. Specimen no. 37E-CR-1 is $205 \mathrm{~mm}$ long, but is incomplete. The greatest diameter of the distal end is $52 \mathrm{~mm}$, and the least diameter of the shaft near midlength is $20 \mathrm{~mm}$. The somewhat larger coracoid (no. 37-CR-2) has a greatest proximal diameter of $122 \mathrm{~mm}$.

Enough is preserved of the scapulae (nos. 37-CR-4 and -5 ) is preserved to indicate a close resemblance to the peculiar bone of $H$. natator figured by Troxell (1925, fig. 7A). Evidence of the exceptionally developed coracoid lobe is seen in no. 37-CR-5 (fig. F23B). It is likely that in adult individuals this process was even more accentuated, as indi- cated in Troxell's illustration. The scapular spine is short, lies posterior to the leading edge of the scapula, and is largely confined to the coracoid lobe. The beginning of the great dorsal expansion of the scapular blade is also evident, and between the blade and the coracoid lobe the bone is deeply emarginated, as in $H$. natator.

The glenoid cavity is formed by subequal parts of the scapula and coracoid. It has the usual saddle-shaped character, but is somewhat hourglass-shaped owing to a considerable narrowing of the middle (fig. F23C). The glenoid, formed by uniting nos. 37E-CR-1 and 37-CR-4, which are about the same size, has a dorsoventral diameter of $60 \mathrm{~mm}$.

Forelimb.-Massive ends of humeri are frequently preserved, but there is not one complete humerus in the collection. The most nearly complete example is a small isolated right humerus, no. 3-CR-1 (fig. F24B). Its proximal end is missing, but there is an end from a humerus of similar size from locality 33 (no. 33-CR-3) (fig. F24A). Large right proximal and distal ends of differing size were collected at locality 37 , but whether either of them belongs to no. 37-CR-1 is unknown. Specimen no. 3-CR-1 is a little longer than the humerus of $H$. natator figured by Troxell (1925, fig. 8), but it is nevertheless more slender in the shaft and the distal end is less expanded. However, the head (no. 33-CR-3) seems almost identical to the Hyposaurus humerus. The only difference I can see between the Saudi Arabian specimens and the humerus of $H$. bequaerti (Swinton, 1950, pl. 6) is that the shaft of no. 3-CR-1 is straighter and the distal end is less expanded on the posterior (medial) 


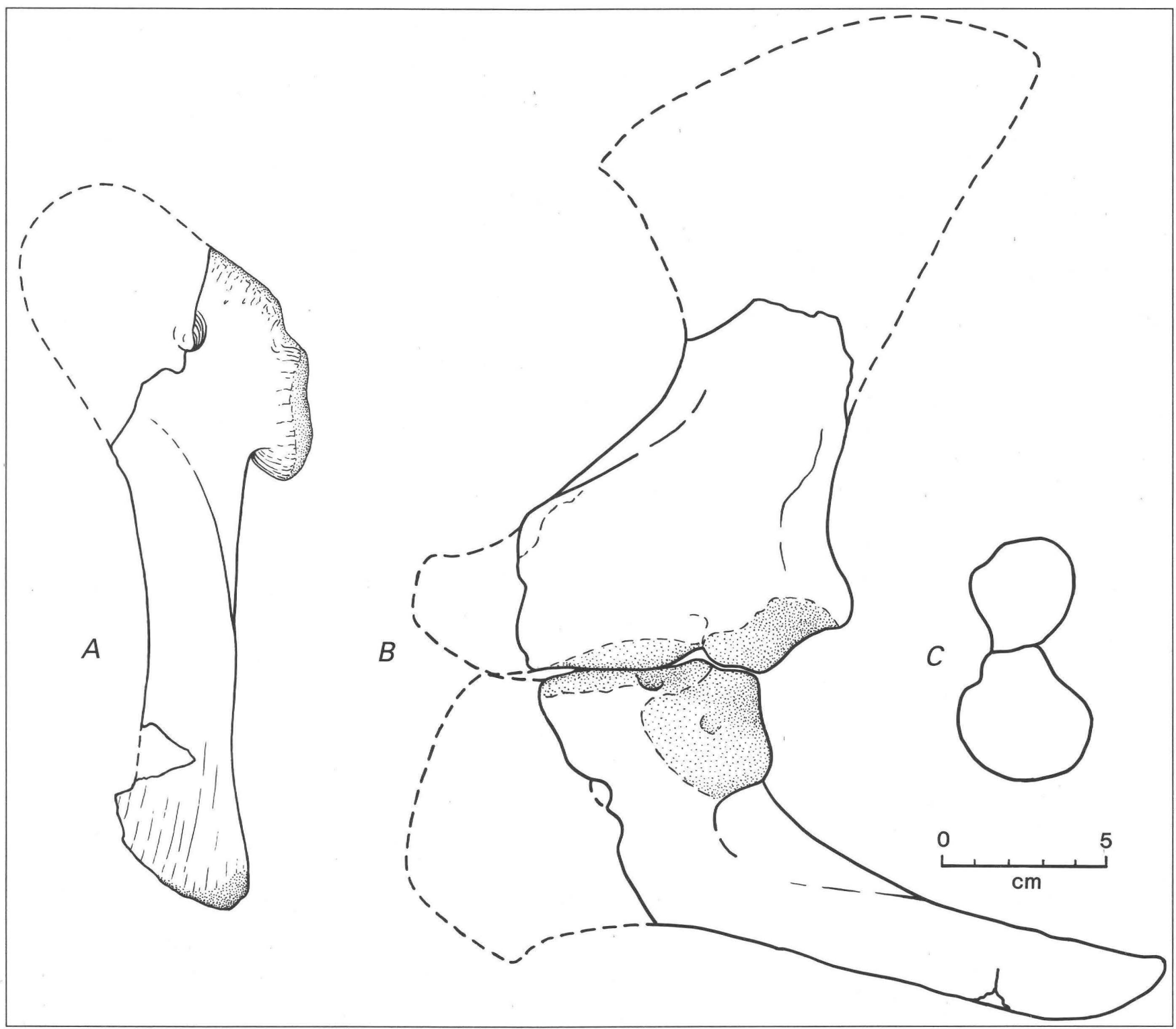

Figure F23. Rhabdognathus sp., pectoral girdle. A, left coracoid, no. 37E-CR-1, anteroventral aspect to show shape of sternal ramus; $B$, left scapula and coracoid, lateral aspect, reconstructed from nos. 37E-CR-1, 37-CR-4, 37-CR-5, and the scapula of Hyposaurus natator; C, glenoid surface showing pronounced hourglass outline.

side. Expansion of the ends and the resulting curvature of the sides of the shaft evidently increase with size, as the larger specimens in the collection agree better with the Hyposaurus humerus in these regards.

Both Troxell and Swinton remarked upon the long and low delto-pectoral ridge in Hyposaurus as compared to the ridge in Crocodylus. Their comments apply as well to the humerus of Rhabdognathus sp. Those authors were, however, impressed with the general similarities between the Hyposaurus and Crocodylus humerus. These similarities are less apparent to me. The humerus of $H$. bequaerti as well as the specimens from Saudi Arabia are longer, straighter, and more slender than in the crocodile. The distal end is also less expanded.
The proximal end of the humerus no. 37-CR-7 is evocative of that in some ornithopod dinosaurs (fig. F25B). The large smoothly rounded caput is more distinct on the dorsal surface. The posterior tuberosity, which in eusuchians slants sharply away from the caput posterolaterally, forms a rounded mass only a little smaller than the caput at the posterior corner of the head. The anterior tuberosity is not differentiated from the caput, so all three elements are confluent and lie roughly in a single plane. Thus, when viewed from above or below, the proximal end of the humerus has the squared-off appearance noted in Hyposaurus by Troxell (1925) and Swinton (1950).

A distal end of a right humerus (no. 37-CR-6) is especially well preserved (fig. F25A). The smooth-surfaced 
Table F5. Measurements of selected humeri

[In millimeters]

\begin{tabular}{|c|c|c|c|c|c|c|}
\hline & 2-CR-1 & 33-CR-3 & 3-CR-1 & $37-\mathrm{CR}-6$ & 37-CR-8 & $36 \mathrm{~W}-\mathrm{CR}-2$ \\
\hline Anteroposterior diameter, proximal end & 111 & 57 & & & 110 & 72 \\
\hline Greatest dorsoventral diameter of caput & 57 & 27 & & & 65 & 40 \\
\hline Greatest dorsoventral diameter of posterior tuberosity & 49 & 22 & & & 38 & 36 \\
\hline Greatest height of deltopectoral crest (including shaft) & & & 27 & & & \\
\hline Least diameter of shaft & & & 22 & & & \\
\hline Greatest anteroposterior diameter, distal end & & & 40 & 85 & & 54 \\
\hline Greatest dorsoventral diameter of capitulum & & & 26 & 64 & & 45 \\
\hline Greatest dorsoventral diameter of ulnar condyle & & & 24 & 50 & & 31 \\
\hline
\end{tabular}

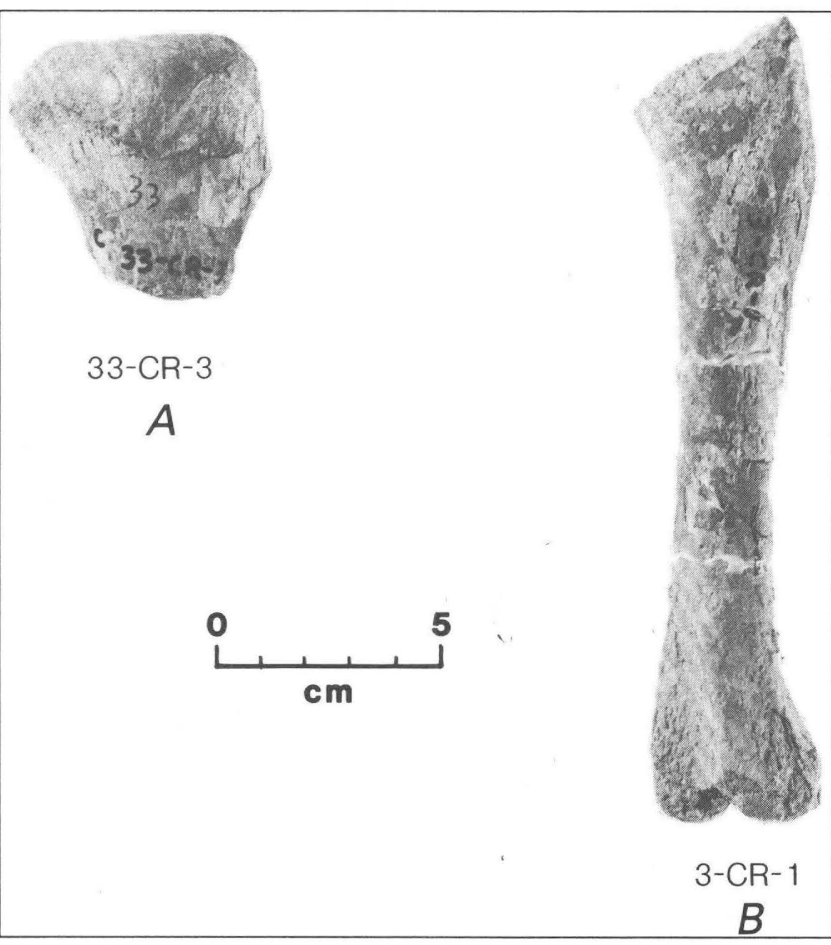

Figure F24. Rhabdognathus sp. $A$, proximal end of right humerus; $B$, right humerus lacking head. Both specimens are from small and relatively immature individuals.

condyles are better rounded than in Crocodylus. They are separated by a broad and shallow intercondylar sulcus that extends onto the dorsal surface of the bone instead of ending in a depression half way up on the distal end as in $\mathrm{Cro}$ codylus. The ulnar condyle is relatively smaller, and the radial condyle (capitulum) relatively larger than in Crocodylus. The ulnar condyle projects beyond the end of the radial condyle.

Measurements of various humeri are given in table F5.

Of forearm bones, only the proximal end of a very large ?left ulna (no. 33-CR-4), the distal end of a much smaller left ulna (no. 33-CR-3), and the distal half of a ?radius (no. 58-CR-1) have been identified.

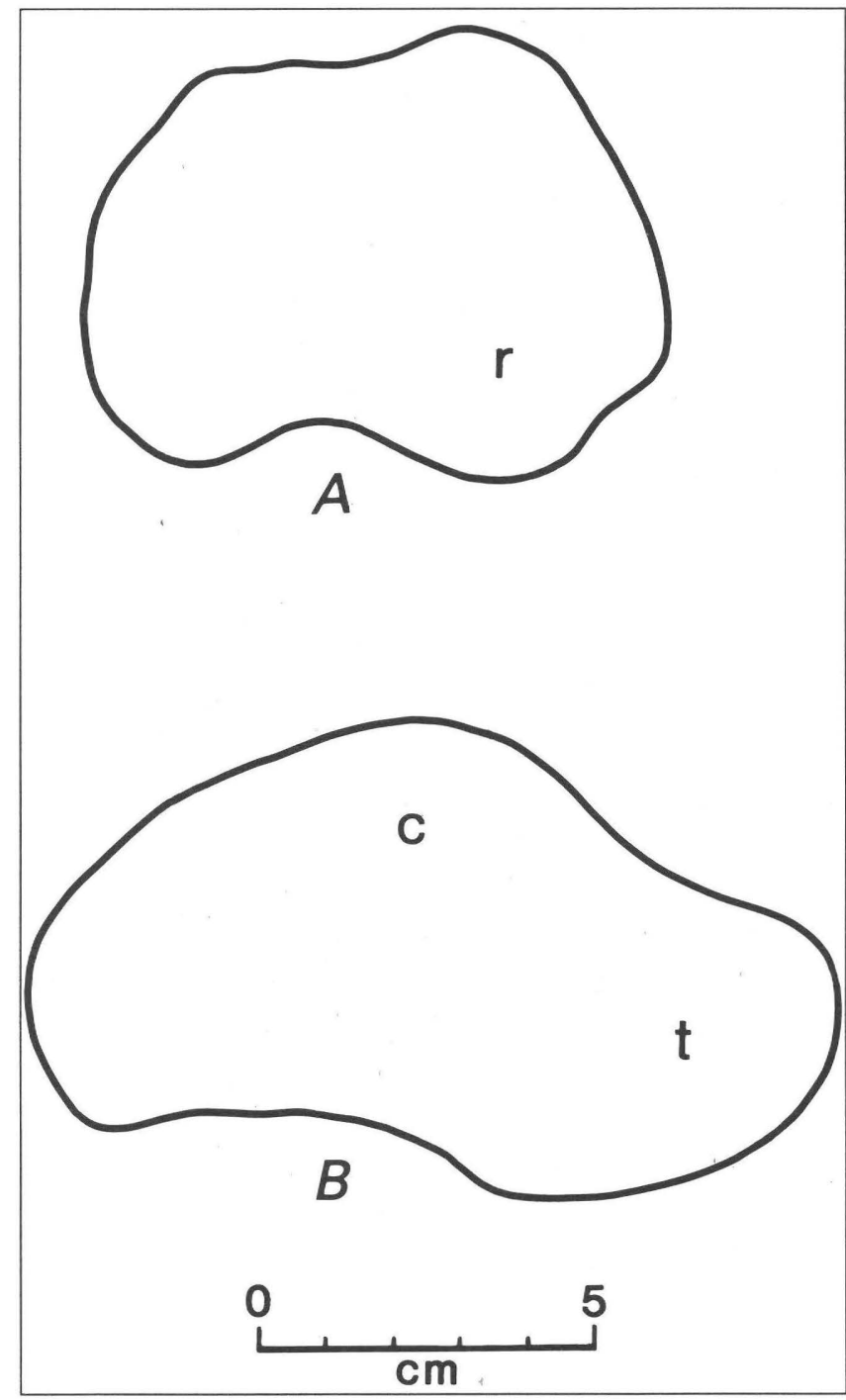

Figure F25. Rhabdognathus sp., articular ends of the humerus of large individuals. $A$, no. 37-CR-6, distal end; $B$, no. 37-CR-6, proximal end; c, caput; $r$, radial condyle; $\mathfrak{r}$, posterior tuberosity. 
Swinton (1950) stated that the ulna of $H$. bequaerti was so typically crocodilian that it required no detailed description. Parris (1986) figures an ulna of Hyposaurus rogersii that confirms Swinton's appraisal. The distal end of the ulna no. 33-CR-3 differs from that of $C$. acutus only in the stronger development of the anterior part of the ulnare surface. This bone is $47 \mathrm{~mm}$ in its quasi-transverse diameter and from 20 to $30 \mathrm{~mm}$ in the direction normal to this measurement.

No manual elements have been recognized in the collection.

Pelvic arch.-Like the pectoral arch, the pelvis in dyrosaurs is more robust than that of other marine mesosuchians and more like the pelvis in eusuchians. Remains of the pelvic bones are available from several localities, but except for the iliac of no. 37-CR-1 none of them is complete. Both sides of the pelvis of no. 37-CR-1 were found semiarticulated with the sacrum. The left ilium is better preserved than the right. It is a thick and massive bone, having the general proportions seen in eusuchians. It differs from the bone of $H$. natator figured by Troxell (1925, fig. 13) mainly in the lesser anterior development of the costalis process, which appears much blunter in no. 37-CR-1. Noteworthy is the depth and narrowness of the acetabulum, which in the right ilium of no. 37-CR-1 is $75 \mathrm{~mm}$ high, 70 $\mathrm{mm}$ anteroposteriorly at the ventral edge of the ilium, and about $45 \mathrm{~mm}$ deep. The acetabular notch on the ventral edge of the ilium is, however, relatively wider than in Crocodylus. The lateral edge of the strong posterior ischiadic peduncle projects outward forming a broad posterior wall for the acetabulum. The articular end of this peduncle contains, laterally, a mammillary process and, medially, a depression, which fit closely the corresponding features of the ischium. The anterior peduncle is similar, but it is more distinctly divided between convex and concave parts by a narrow and shallow channel. The opposing surface on the anterior process of the ischium has an unfinished roughened end without a corresponding pit or mammillary process. This area was, as in existing crocodilians, deeply imbedded in cartilage. The posterior end of the iliac blade resembles in lateral profile that of a $C$. acutus ilium at hand, but its posterior end is a little more broadly rounded. The whole iliac blade is more expanded vertically and is not so thick as in the crocodile. It is broadly excavated laterally. On the medial side, the scars for attachment to the sacral ribs reflect the shape of the ends of those ribs. The area for the second sacral rib resembles that in $C$. acutus, but the facet for the first rib is shallow and higher than wide. In agreement with the configuration of the end of the first sacral rib, it is completely unlike the first sacral rib facet in the crocodile. The left ilium of no. 37-CR-1 is $187 \mathrm{~mm}$ long and 116 $\mathrm{mm}$ high at the level of the posterior ischiadic peduncle.

The proximal end of the ischium resembles that in $C$. acutus, but the area for articulation of the pubis is a low rounded knob at the anteroventral corner of the pubic pro-

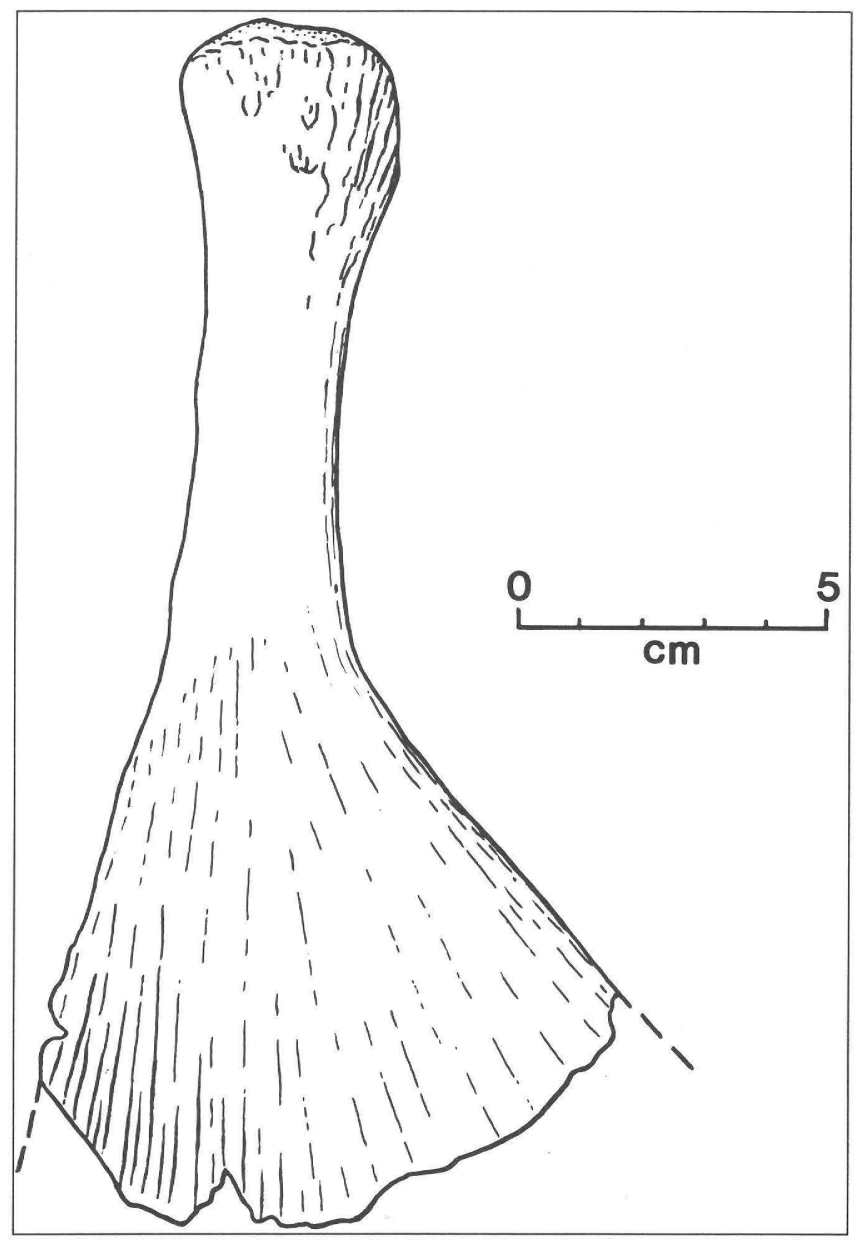

Figure F26. Rhabdognathus sp., no. 58-CR-1, right pubis, ventral aspect.

cess, whereas in C. acutus it is a wide V-shaped facet. The distal part of the ischium is not preserved on any specimen. The ischium surrounds the lower two-thirds of the vertically ovate acetabular foramen. The opening in the right half of the pelvis is $44 \mathrm{~mm}$ high and $25 \mathrm{~mm}$ long. According to Troxell (1925, p. 510), this part of the ischium in H. natator is "...narrow and pointed and not broad as in the true crocodiles, and, having a sharp edge and an acute termination, it appears never to have actually joined its fellows on the midline." Swinton (1950), on the other hand, describes the distal end of the ischium in $H$. bequaerti as much expanded, the more usual crocodilian condition.

Parts of several pubes are available, including proximal ends of opposite elements and the distal end of one belonging to no. 37-CR-1. The most complete pubis in the collection is the right element of no. 58-CR-1, which is missing only a little from around the distal end (fig. F26). The pubis is spatulate with a thick round shaft and a slightly enlarged blunt proximal end, which is excavated in the center of the articular surface to receive the corresponding low rounded knob on the ischium. Distally, the bone flares out to 
Table F6. Comparative measurements of dyrosaurian femora

[In millimeters]

\begin{tabular}{|c|c|c|c|c|c|}
\hline & $\begin{array}{l}\text { 37-CR-1 } \\
\text { right }\end{array}$ & $\begin{array}{c}\text { 37-CR-1 } \\
\text { left }\end{array}$ & $58-\mathrm{CR}-1$ & $\begin{array}{l}\text { H. bequaerti } \\
\text { from Swinton }\end{array}$ & $\begin{array}{l}\text { D. paucidens } \\
\text { from } \\
\text { Arambourg }\end{array}$ \\
\hline Length & 349 & 351 & & 300 & 339 \\
\hline Antero-posterior diameter of head & 84 & & 77 & 75 & 81 \\
\hline Greatest dorso-ventral diameter of head & 50 & 51 & 47 & 48 & 49 \\
\hline Greatest diameter across condyles & 170 & & 67 & 70 & 73 \\
\hline Least diameter of shaft & 40 & 41 & 35 & & 40 \\
\hline Distance from proximal end to highest point of fourth trochanter & 118 & 119 & 108 & 105 & \\
\hline Distance from distal end to highest point of fourth trochanter & 231 & 232 & & 195 & \\
\hline
\end{tabular}

${ }^{1}$ Estimate

Figure F27. Rhabdognathus sp., tibia. A, no. 37-CR-1, right $\rightarrow$ tibia, anterior aspect; $B$, outline of distal end of left tibia (reversed) drawn to same scale as $A$. Ant., anterior.

a greater degree than indicated in H. natator (see Troxell, 1925, fig. 12), and the distal edge, seen in the left pubis of no. 37-CR-1, is not so square cut as there. I find no evidence that opposite pubes touched each other in the midline distally as shown by Troxell. The pubis of no. 58-CR-1, lacking its distal edge, is $200 \mathrm{~mm}$ long as preserved. Its proximal end has principal diameters of 34 and $37 \mathrm{~mm}$, and the least transverse diameter of the shaft is $23 \mathrm{~mm}$. Its distal end is $95 \mathrm{~mm}$ across, that of no. 37-CR-1, which is incomplete, is $114 \mathrm{~mm}$.

Hind limb.-The hind limb is best represented by both femora, one complete and one incomplete tibia, and an incomplete fibula of no. 37-CR-1. Specimen no. 58-CR-1 includes the proximal and distal ends of the right femur and the distal end of the left, as well as various pieces of the tibiae. Other incomplete hind limb bones from other localities, including many pieces of tibiae, are also present.

Dyrosaurian femora have been described by several authors (Arambourg, 1952; Troxell, 1925; Swinton, 1950). Arambourg notes a number of features that distinguish the femur of Dyrosaurus paucidens from those of nondyrosaurian crocodiles. These features include an almost circular cross section of the shaft (I believe of questionable significance); the strong anterior projection of the head, and backward curvature of the distal end; and the oblique twisting of the axial plane of the head. The last feature has been reported frequently by other authors as well.

The femora of Rhabdognathus sp. conform to Arambourg's description and resemble the femora of $H$. bequaerti (see Swinton 1950, pl. 7), and H. natator (Troxell 1925, fig. 9). Although the Rhabdognathus bones appear more slender than those mentioned above, this is not borne out by comparative measurements (table F6).

The dyrosaur tibia and fibula have not been usefully described. The right tibia of no. 37-CR-1 (fig. F27A) is the only complete tibia in the collection, but the ends of the left

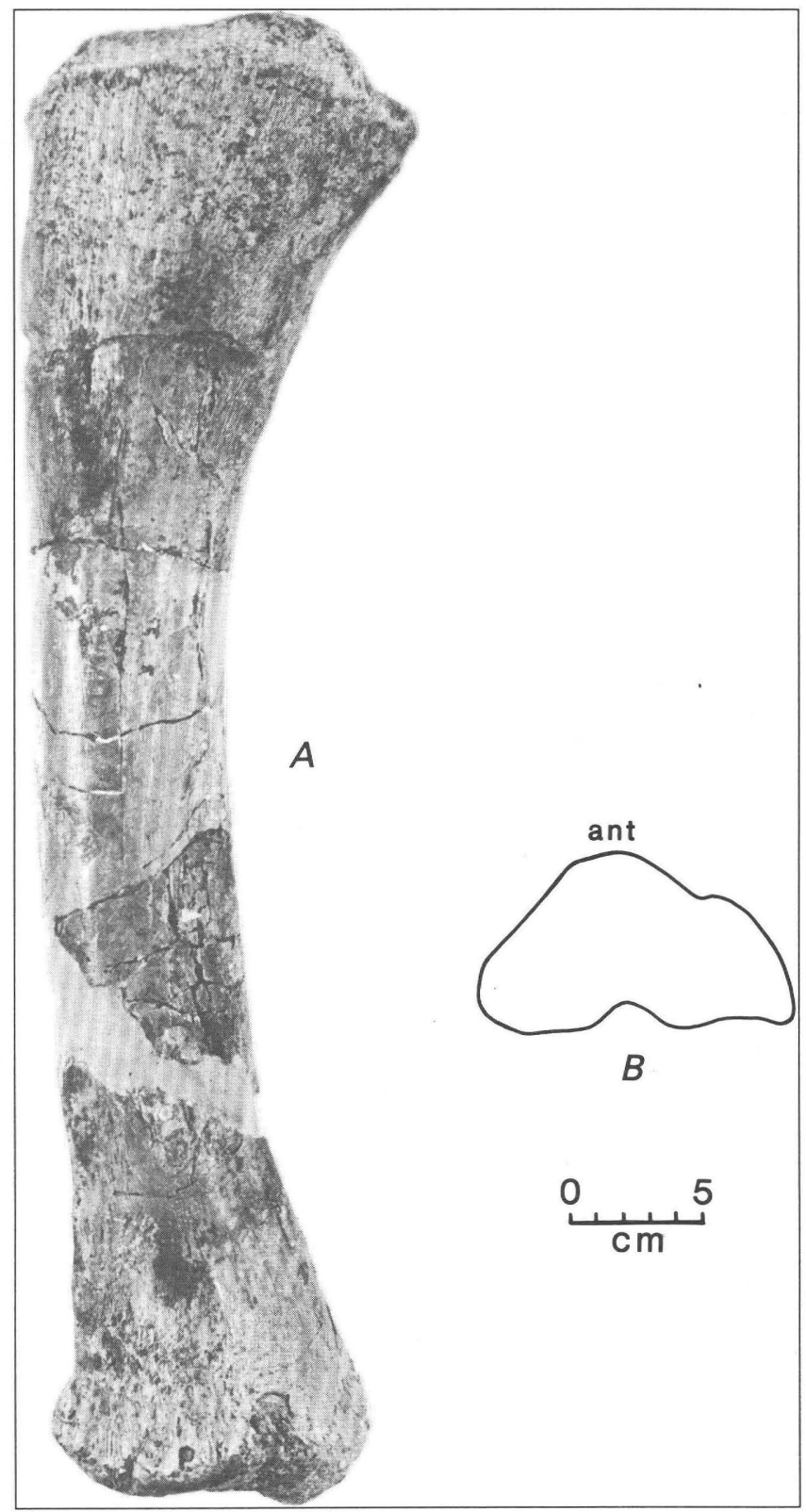


Table F7. Measurements of tibiae

[In millimeters]

\begin{tabular}{|c|c|c|c|c|c|c|c|c|}
\hline & $\begin{array}{c}\text { 37-CR-1 } \\
\text { right }\end{array}$ & $\begin{array}{c}\text { 37-CR-1 } \\
\text { left }\end{array}$ & 58-CR-1 & 31-CR-1 & 33-CR-5 & $60-\mathrm{CR}-1$ & $60-\mathrm{CR}-2$ & 33-CR-8 \\
\hline Length & 281 & & & & & & & \\
\hline Transverse diameter proximal end & & & & 55 & & & $66+$ & 56 \\
\hline Least diameter of shaft & 23 & & & & & & & 22 \\
\hline Transverse diameter distal end & 35 & 35 & 30 & & 40 & 44 & & 30 \\
\hline
\end{tabular}

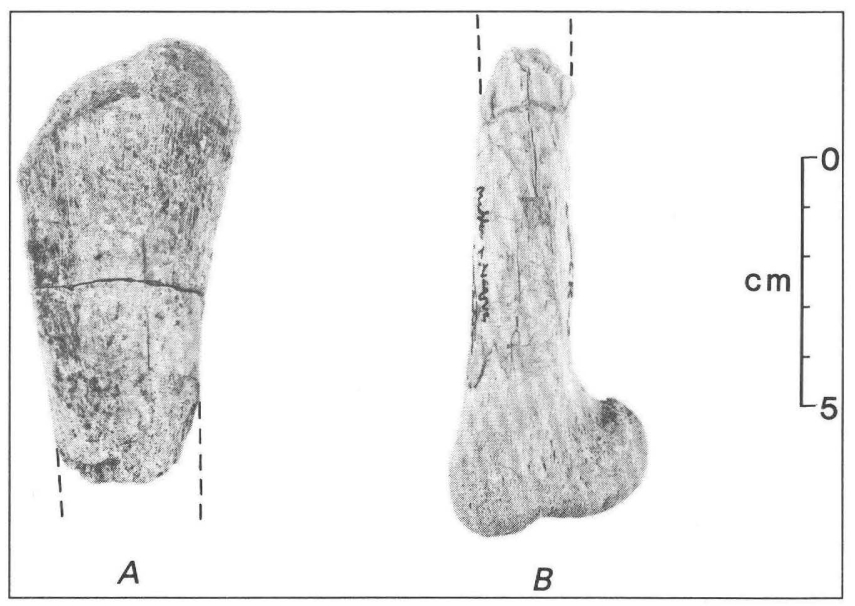

Figure F28. Rhabdognathus sp., A, no. 37-CR-1, proximal end of left fibula, left lateral aspect; $B$, no. 60-CR-3, distal end of right fibula, posterior aspect.

tibia are better preserved. There are, in addition, ends of several tibiae from other localities. The tibia of no. 37-CR-1 is four-fifths the length of the femur and is thus relatively a little shorter than the tibia in most existing eusuchians (see data in Knusel, 1944). The shaft is transversely oval throughout and appears gracile when compared to the femur. The proximal end is as in eusuchian crocodiles. The articular head, thickly capped by cartilage in life, shows the characteristic hummocky surface with a central depression. The cnemial crest, as usual in crocodiles, is ill defined, but the anterolateral edge of the bone is thickened proximally. The expansion of the head, rising from the shaft, is more gradual than in Crocodylus. The distal end of the tibia is thicker, and the fibular crest is sharper and straighter than in C. acutus. This condition is accentuated distally by the broad excavation of the posterior side of the shaft. In the crocodile tibia there is here a limited triangular pit proximal to the astragalar articulation, but this is lacking in Rhabdognathus sp. The distal articular surface is broader and shows considerably more relief than in the crocodile (fig. F27B), but it resembles Alligator mississippiensis somewhat more. That part of the bone which lodges in the dorsomedial facet of the astragalus is very broad relative to the rest of the articular surface. This part is set off from the ventro-medial angle of the distal end by shallow longitudinal sulci on the anterior and posterior faces of the diaphysis. The anterior groove dies out shortly above the end, whereas the posterior one is confluent upward with the broad posterior excavation mentioned above. The two grooves do not extend across the ventral end of the bone, however. Ventromedially, and composing about one-quarter of the area of the distal end, is a convex triangular surface. This surface is bounded laterally by a rounded triangular prominence that extends below the level of the rest of the bone. Medial to this prominence, the area is traversed by a broad but shallow channel that carried the flexor tendon of the hallux. For measurements of tibiae see table F7.

The fibula of Dyrosaurus paucidens was described and figured by Arambourg (1952). This bone is remarkably stout and bears an obtuse ridge proximally on its lateral surface.

Proximal and distal ends of the left fibula are preserved in no. 37-CR-1, and there is also a perfectly preserved distal end of a left fibula, no. 60-CR-3. Viewed from the side (fig. F28A), the expanded proximal end of the fibula has the same oblique top seen in existing crocodilians, but this grades downward more gradually into the shaft than in a $C$. acutus fibula. The facet that receives the posterior condyle of the femur is less deeply excavated than in the crocodile. What remains of the shaft is irregularly oval in cross section. The bone appears to have been relatively stout, as in $D$. paucidens, but there is no trace laterally of the obtuse ridge that occurs in $D$. paucidens near the proximal end of the bone. The surface here is flat and featureless in Rhabdognathus sp. The distal end of the fibula is less flattened anteroposteriorly, and the astragalar condyle is much better developed than in eusuchians. The whole distal end possesses more relief and in some respects is evocative of the head of a mammalian humerus (fig. F28B). The astragalar condyle is large and well rounded and stands out from the shaft at an angle of 90 degrees. The surface that rests on the calcaneum is slightly concave, and posterolaterally there is a slight ventral projection that overlaps the lat- 
eral edge of the fibular head of the calcaneum. This process is ill defined in the Crocodylus fibula.

The diameters of the proximal end of no. 37-CR-1 are $46 \mathrm{~mm}$ (anteroposterior) and $15 \mathrm{~mm}$ (transverse); those of the distal end of no. 60-CR-3, which is about the same size as no. 37-CR-1, are $29 \mathrm{~mm}$ (anteroposterior) and $38 \mathrm{~mm}$ (transverse).

Pes.-Foot bones of Rhabdognathus sp. are well represented. Most of the tarsal elements of both feet are present in no. 37-CR-1, which also includes a number of incomplete metatarsals (fig. F29). The right astragalus, calcaneum and tarsal IV, and some incomplete metatarsals are also preserved in no. 58-CR-1. Isolated foot bones were encountered at several other localities.

The pedal skeleton of fossil crocodiles has been largely neglected until recent years, one suspects, because of the very complicated geometry of the tarsus. Cruickshank (1979), Brinkman (1981), and Hecht and Tarsitano (1983) have furnished useful descriptions of the tarsus in crocodilians and related archosaurs. In this description I shall follow the terminology used by Hecht and Tarsitano, which is modified from Cruickshank.

The tarsals of Rhabdognathus sp. are massive and well ossified. The astragalus and calcaneum are illustrated in fig. F30. The calcaneum does not differ much from that of a large Crocodylus or Alligator, but the tuber (fig. F30, Tc) is thicker and a little shorter than in those genera. A low, rounded ridge connects the tuber with the fibular condyle (fig. F30, Fc) laterally; this ridge is much more pronounced in the fossil than in either of the existing taxa, but the difference may be owing to the large size of the Rhabdognathus specimens. The distal end of the tuber is irregularly teardrop shaped when viewed from behind. The usual deep dorsoventral groove for the long flexor tendons of the foot is represented by an oval excavation surrounded by a tumid rim, much as in existing eusuchians. The root of the tuber gives the impression of being much flatter dorsoventrally and broader transversely than in Crocodylus or Alligator, owing to the dorso-lateral hypertrophy of the abovementioned ridge. The surface of the fibular condyle is, of course, convex; however, it is narrower than in the existing taxa, whereas the astragalar surface (which adjoins the surface for the fibula) is relatively broader and slants diagonally away mesad from the fibular condyle at an angle of about 45 degrees. The flattened anteroventral facet for the fourth distal tarsal (fig. F30, Dt4f) is broad and subreniform in outline. It does not display the irregular configuration sometimes seen in existing forms.

The astragalus displays several differences from the eusuchian condition. Most important is the broad, helical saddle-shaped tibial facet (fig. F30, Tf), which contrasts sharply with the narrow and irregularly band-shaped articular surface in eusuchians (see Hecht and Tarsitano, 1983their U-shaped tibial facet). The backwardly hooked posteromedial arm of the $\mathrm{U}$ and the deep astragalar fossa present

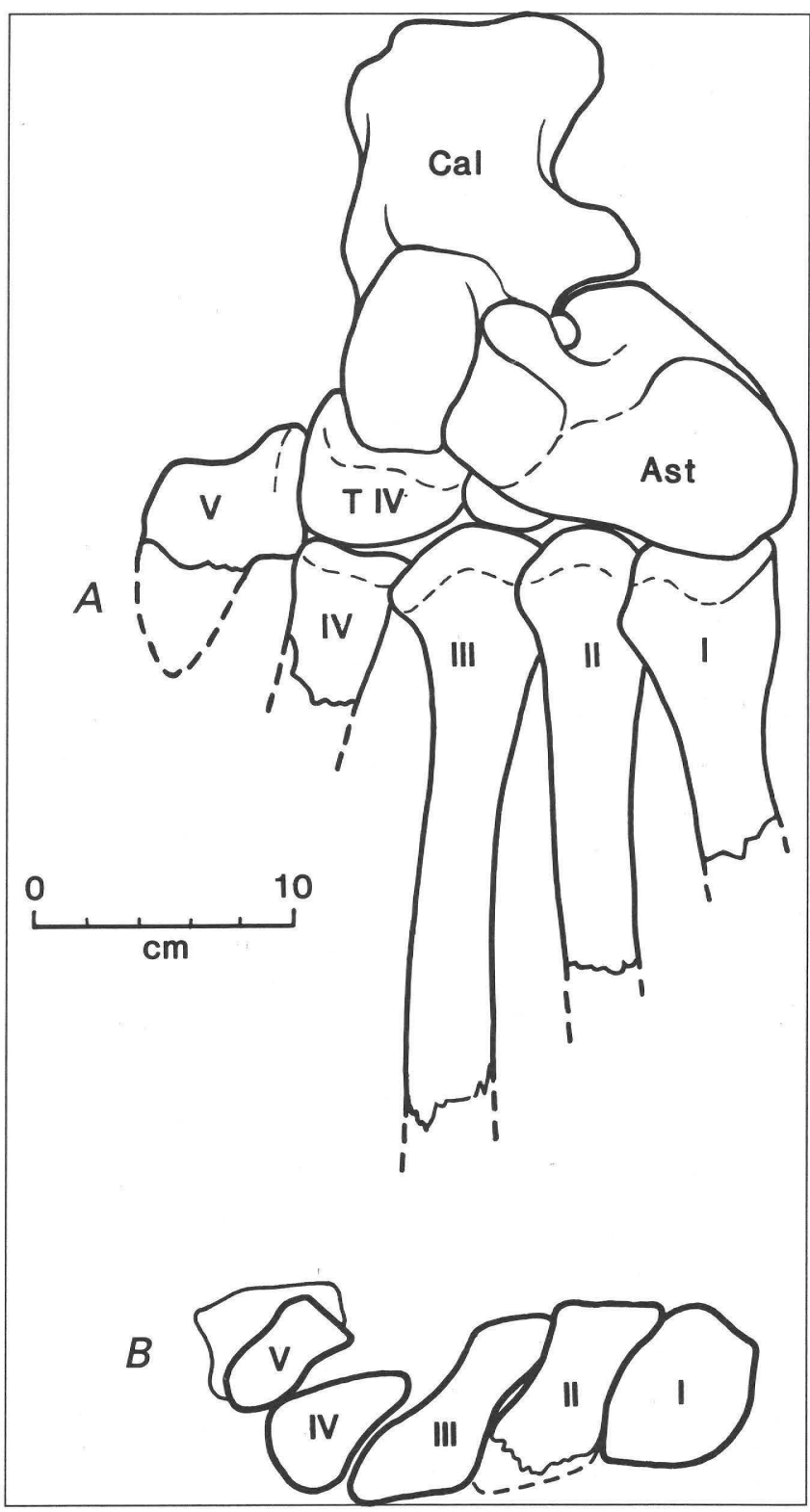

Figure F29. Rhabdognathus sp., right pes, reconstruction based largely on right and left elements of nos. 37-CR-1 and 58-CR-1. A, tarsus and incomplete metatarsus, dorsal aspect; $B$, articular ends of metatarsals. Ast, astragalus; Cal, calcaneum; TIV, fourth distal tarsal; I-V, metatarsals.

in eusuchians are lacking in Rhabdognathus sp. The fossa is represented by only a small, shallow, oval pit from which a narrow and very shallow diagonal sulcus issues in a posterolateral direction. The area of the tibial facet, which in eusuchians forms the slightly elevated posterior arm of the $\mathrm{U}$, curves smoothly over the anterodorsal surface of the bone. This arrangement should have permitted a greater degree of extension at the ankle joint than is usual in eusuchians. The fibular facet (fig. F30, Ff) is more regularly rectangular than in either Alligator or Crocodylus. 


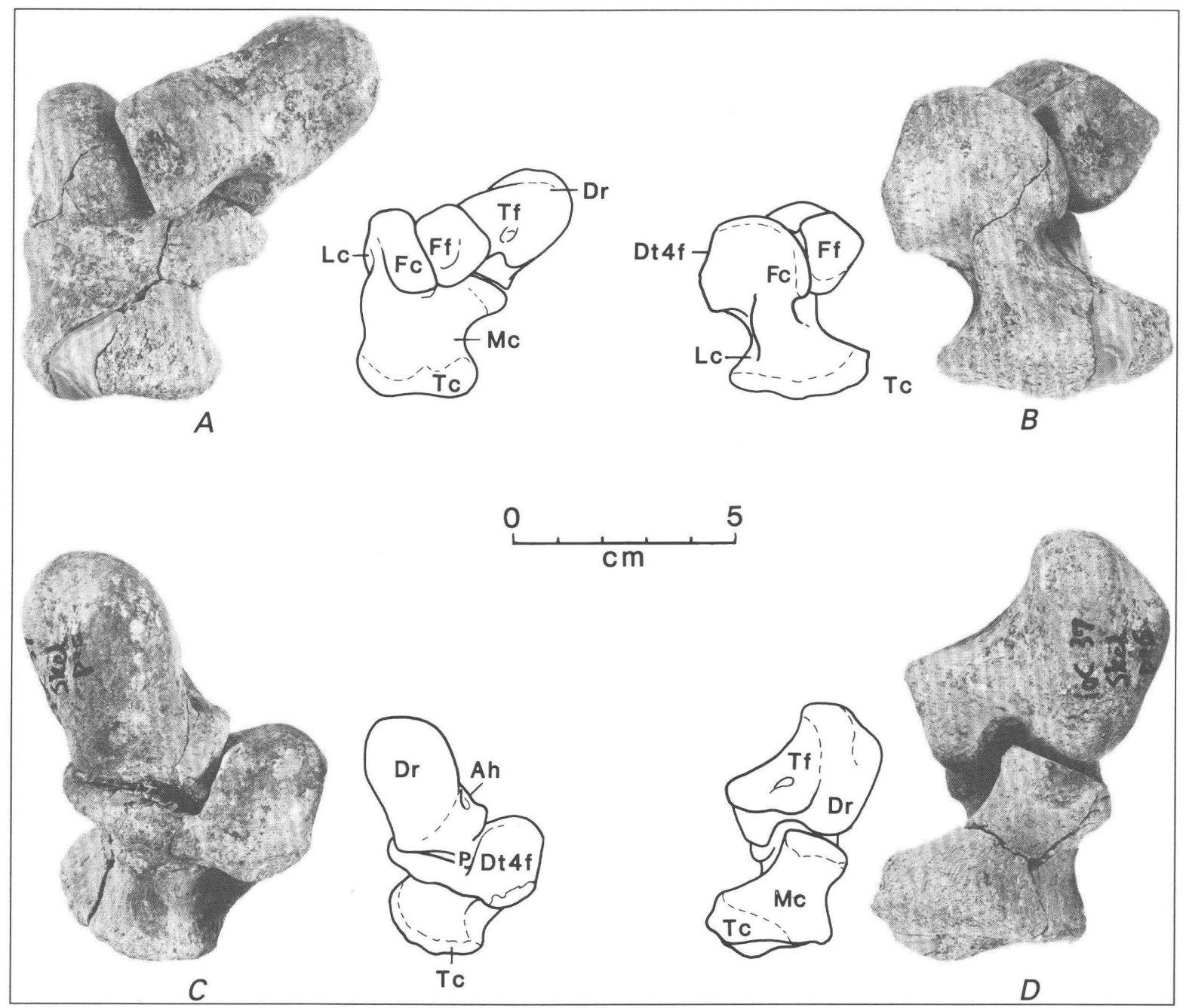

Figure F30. Rhabdognathus sp., no. 37-CR-1, left astragalus and calcaneum. $A$, proximal; $B$, lateral; $C$, distal, $D$, medial surfaces. Ah, anterior hollow of astragalus; Dr, distal roller of astragalus; Dt4f, facet for distal tarsal 4; Fc,

Distally, the so-called distal roller (fig. F30, Dr) surface, which articulates with metatarsals 1 and 2, resembles the roller in $C$. acutus, but it appears to project more strongly anteromedially in Rhabdognathus sp. This may be illusory, however, owing to the somewhat less expanded tongue of the calcaneum that abuts against the astragalar trochlea. The astragalar peg (fig. F30, P) is stouter than in either Crocodylus or Alligator and projects a little more strongly into the corresponding socket of the calcaneum. In eusuchians an articular surface on the astragalar trochlea is continuous from the fibular facet-from which it is set off by an obtuse angle- to the astragalar peg. This surface is in sliding contact with the tongue of the calcaneum. But in Rhabdognathus sp. the articulation between the calcaneum and astragalus appears to have permitted a greater range of motion and to have allowed more rotation around the trochlea and peg than in the eusuchians. fibular condyle; Ff, fibular facet; Lc, lateral channel of calcaneum; Mc, medial channel of calcaneum; P, astragalar peg; Tf, tibial facet of astragalus; Tc, calcaneal tuber.

The condition of the ankle joint suggests more freedom of motion of the foot in the fore and aft direction than occurs in existing crocodiles. At the same time, however, side-wise movement was evidently even more restricted in the dyrosaur than in eusuchians.

The fourth tarsal (fig. F29, TIV) is expanded in two planes at approximately right angles to each other. It articulates with the calcaneum along a flattened, roughly triangular posterior surface that curves slightly forward above. The dorsal surface onto which this curvature passes is mostly nonarticular. In contrast to the eusuchian state, this surface is extensive, higher in front than behind, and about twice as wide as it is long. Curiously, it does not extend completely to the anterodorsal edge of the opposing facet on the calcaneum. One would suppose that this allowed for some sliding of the fourth tarsal up and down against the calcaneum; however, movement in this direction is inhibited by a poste- 
riorly developed hooklike process on the ventral side of the fourth tarsal. This arrangement is puzzling because the articular surface on the calcaneum is well developed and the unopposed part does not differ from the area that is in contact with the fourth tarsal. The condition is natural and is also present in no. 58-CR-1. The ventral (plantar) part of the fourth tarsal is expanded anteroposteriorly and is narrow transversely, thus forming a blunt heellike edge quite different from the transversely expanded quadrangular surface in Crocodylus. Anterolaterally, a broad semilunar facet is present for attachment of the fifth metatarsal. In Crocodylus, on the other hand, the proximal end of this metatarsal is inserted into a wide groove which occupies virtually the entire side of the tarsal. The anterior surface of the fourth tarsal, which articulates with the fourth metatarsal, is curved upward allowing for a considerable arc of vertical rotation at this point. Laterally, the anterior half of the tarsal is set off from the posterior, anteroposteriorly-expanded part of the bone by an obtuse angle. This side of the bone carries a facet, shaped roughly like a figure 8 , that opposed the medial surface of the third tarsal (in no. 58-CR-1 the figure 8 is interrupted in the middle; thus, there are two facets).

The third tarsal is an irregularly shaped block of bone whose orientation in the tarsus is uncertain. As in existing crocodilians, it was no doubt surrounded by a considerable mass of cartilage.

Most of the metatarsals, lacking varying amounts of the distal ends, are preserved in no. 37-CR-1 (fig. F29). A distal end of one metatarsal of undetermined position is also present. The bones of the left side are less distorted than those of the right side. The first four metatarsals are massive bones with thick proximal ends. They do not differ much from the corresponding bones in eusuchians in their articular relationships to each other and in the outlines of the proximal ends (fig. F29B). The same may be said of the fifth metatarsal except that its proximal end is not inserted into a medial depression on the fourth tarsal. This metatarsal does not have the ventrolateral hook seen in eusuchians, but instead ends bluntly. The lengths of metatarsals one to four are unknown. However, the proximal phalanx of the fourth toe is complete and is $62 \mathrm{~mm}$ long. If the same relationship between metatarsal and phalangeal lengths seen in Crocodylus existed in Rhabdognathus sp. the metatarsus of no. 37-CR-1 would have been about $190 \mathrm{~mm}$ long.

Right IV-1 of no. 37-CR-1 and left I-1 of no. 45-CR-1 are the only phalanges in the collection. They are not noticeably different from those phalanges in the crocodile, but no. 37-CR-1 appears to be a little thicker than would be expected in a C. acutus of this size.

Costal cartilages.-Of unusual occurrence is the preservation of a number of pieces of the costal cartilages in no. 58-CR-1 (fig. F31). These are mostly flat, bladelike objects, expanded proximally to form facets for the ends of the ribs, and displaying a characteristic pitted appearance on all surfaces. Their respective positions in the chest wall have not

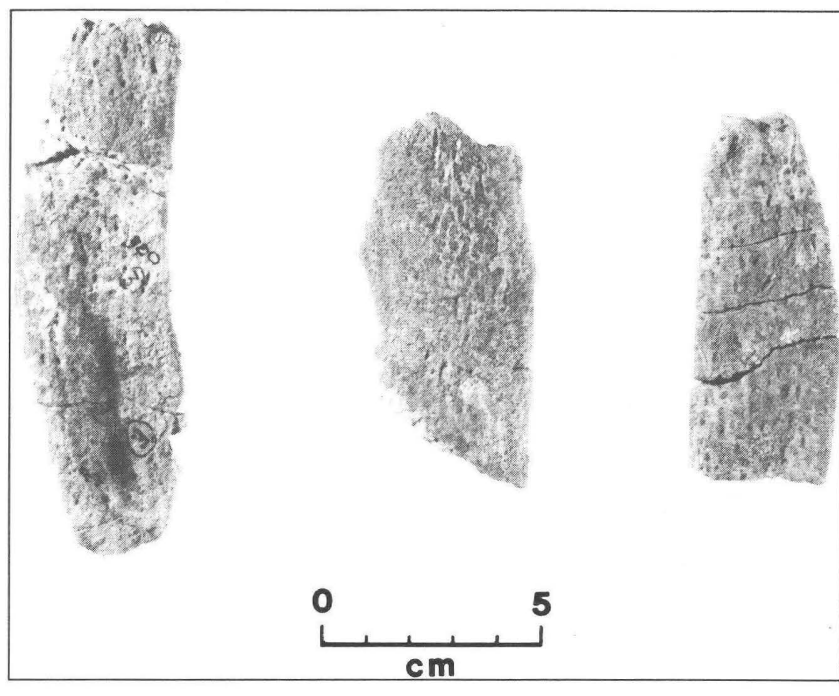

Figure F31. Rhabdognathus sp., no. 58-CR-1. Costal cartilages.

been determined. The largest piece, a proximal end, had a maximum anteroposterior diameter of more than $48 \mathrm{~mm}$. Like all other pieces preserved, this one is thicker toward the posterior edge (about $10 \mathrm{~mm}$ ) and thins to a relatively sharp edge anteriorly.

Osteoscutes.-Osteoscutes are fairly common in the collection, but most are fragmentary. The best examples belong to no. 58-CR-1. The armor of Rhabdognathus sp. consisted of, on either side of the midline, a longitudinal row of overlapping quadrangular plates, which were sutured laterally to a parallel series of undetermined shape (fig. F32). The thoracic scutes (fig. F $33 A-C$ ) bear no crests or peaks. A few of the plates, which are a little thicker and a little shorter than others, are slightly arched transversely. These may have been more anterior in position than the flatter plates. There is no trace of peg and socket articulations laterally. The superior surfaces are strongly pitted with fairly regular round to oval excavations on well over half the surface area. The fore and aft edges of these plates are generally parallel to each other, and the medial side lies at right angles to them. The lateral edge, however, forms an acute angle with the anterior edge and an obtuse angle with the edge behind. In cross section, these plates resemble the section of an airplane wing. A smooth, beveled transverse strip along the anterodorsal edge was overlapped by a thinner, beveled posterior edge of the plate in front. The medial edge is pinched off and nonsutural, but the lateral edge bears a strong suture. What is probably the medial part of a lateral scute, identified by the opposite course of its sutural edge, still shows both anterior and posterior beveling. It is thickest in the middle with the ventral surface being more convex anteroposteriorly than the dorsal side. The lateral outline of this plate is unknown, but there is some evidence that its posterior edge may have been curved gently forward toward the end. Whether a third row of scutes existed laterally is unknown. 




Figure F32. Rhabdognathus sp., reconstruction of dorsal armor, based on osteoscutes from no. 58-CR-1. The lateral extent of the lateral plates is unknown. M, midline.

It is generally believed that dyrosaurs lacked neck shields. Fragments of some very massive plates from locality 60 are, however, less regular in outline and are more coarsely sculptured (they have relatively fewer and more widely spaced pits) than the thoracic plates of no. 58-CR-1. They may be neck shields, but they may belong to Phosphatosaurus. One of the fragments is $23 \mathrm{~mm}$ thick. Another plate, in no. 33-CR-6, has two adjoining sutural edges, and its irregular shape suggests that it may have been part of a nuchal shield (fig. F33D).

Ventral armor consists of irregularly hexagonal to quadrangular osteoderms completely bounded by sutural edges (fig. F33E, F). These scutes are flat. The radiating pattern of the surficial pits is more obvious than in the dorsal scutes. An impressively massive scute, no. 36E-CR-1 (fig. F33E) is $22 \mathrm{~mm}$ thick. One osteoscute, no. 33-CR-7, (fig. F33G), differs from all the others described. It is subrectangular, shows no clear signs of overlapping relationships, and bears no sutures. It is slightly arched in the middle, contains a relatively large number of small regular suboval pits, and, for its size, is remarkably thin $(8 \mathrm{~mm})$. The position of this plate is unknown.

Selected scutes from no. 58-CR-1 have the following measurements (in millimeters; e, estimate; the ordering is not necessarily sequential).

$\begin{array}{llllll}\text { Length medial edge } & 63 & 65^{\mathrm{e}} & 66 & 58 & 60 \\ \text { Length lateral edge } & 64^{\mathrm{e}} & 65 & 63 & 65^{\mathrm{e}} & 62 \\ \text { Transverse diameter anterior edge } & 86 & 98 & 93 & 84 & 88 \\ \text { Transverse diameter distal edge } & 71 & 89 & 77 & 68^{\mathrm{e}} & 75 \\ \text { Greatest thickness of scute } & 13 & 14 & 15 & 15 & 16\end{array}$

Thevenin (1911) believed Dyrosaurus lacked dermal armor, but Arambourg (1952) showed that this was incorrect. Swinton (1950) found nothing unusual about the dorsal scutes of Hyposaurus bequaerti. He describes them as squarish and biscuitlike (soda crackerlike), with diameters of about $70 \mathrm{~mm}$ and $60 \mathrm{~mm}$. They are, therefore, more nearly square than any of the scutes preserved with nos. 58-CR-1 or 37-CR-1, but the description seems to conform more nearly to the anomalous osteoscute no. 33-CR-7. Dollo's (1914) characterization of the ventral scutes of $H$. bequaerti as quadrangular and arranged in imbricating transverse rows is difficult to reconcile with the known plates of Rhabdognathus sp. It is possible that differences in plate design reflect differing positions in the armor, or they may indicate systematic differences as are displayed by the scutes of Alligator and Caiman, for example (Ross and Mayer, 1983).

\section{PATHOLOGY}

Crocodilians are notorious for their viability in the face of massive trauma and pathological conditions. The dyrosaur remains from Saudi Arabia show little evidence of pathology. However, a left femur (no. 3-CR-3) is grossly deformed in the distal half, which is broken off some distance above the end (fig. F34). What remains of the shaft distal to the fourth trochanter is hypertrophied, and a large necrotic sinus occupies about one-fourth of the broken end. 


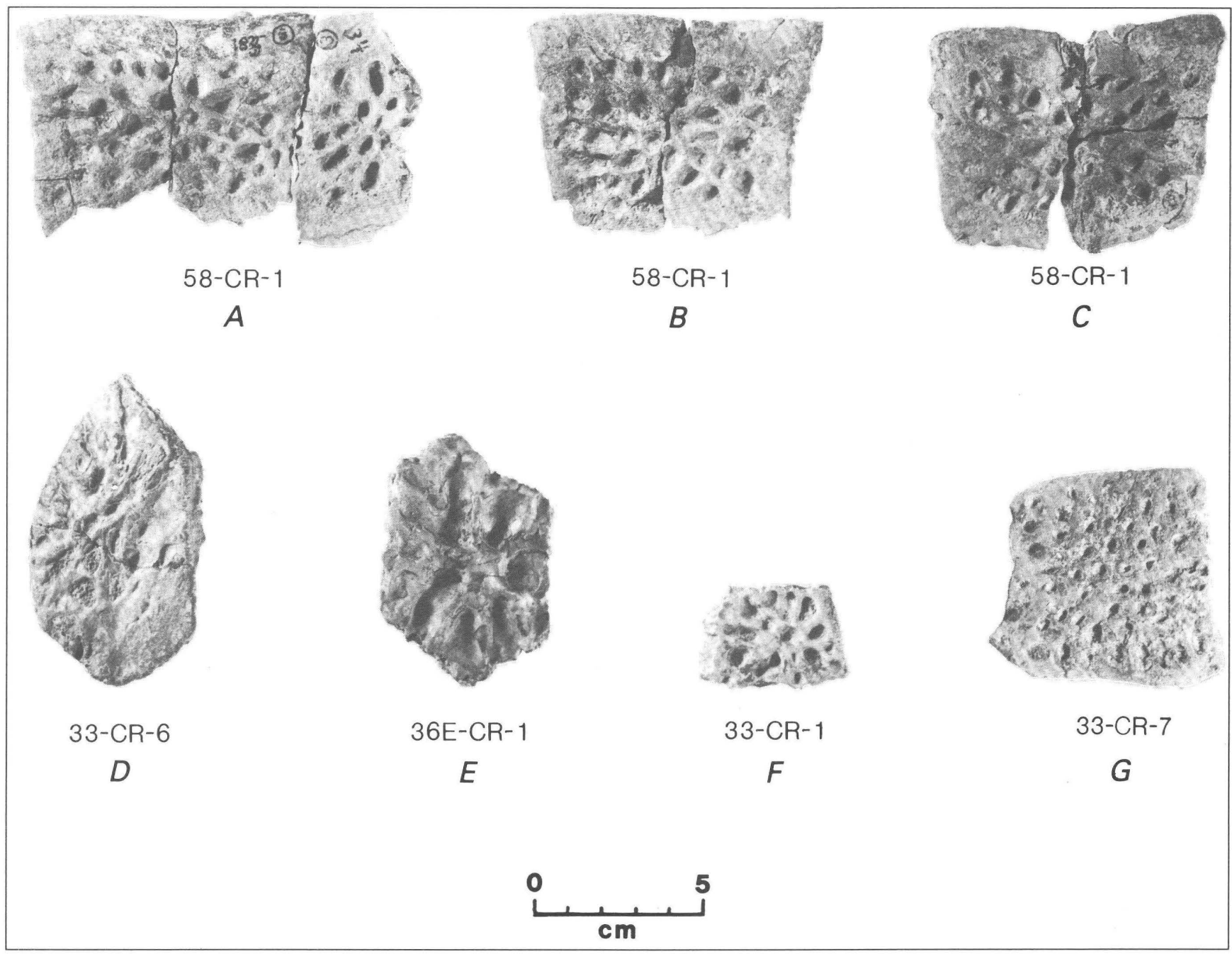

Figure F33. Crocodilian osteoscutes from Saudi Arabia. $A-F$, Rhabdognathus sp., $G$, unidentified taxon. A, medial and lateral thoracic plates of the right side (lateral plate incomplete); $B, C$, right medial plates; $D$, ? nuchal plate; $E, F$, ventral scutes; $G$, osteoscute of uncertain position and taxon, lacking sutures and evidence of overlapping relationships.

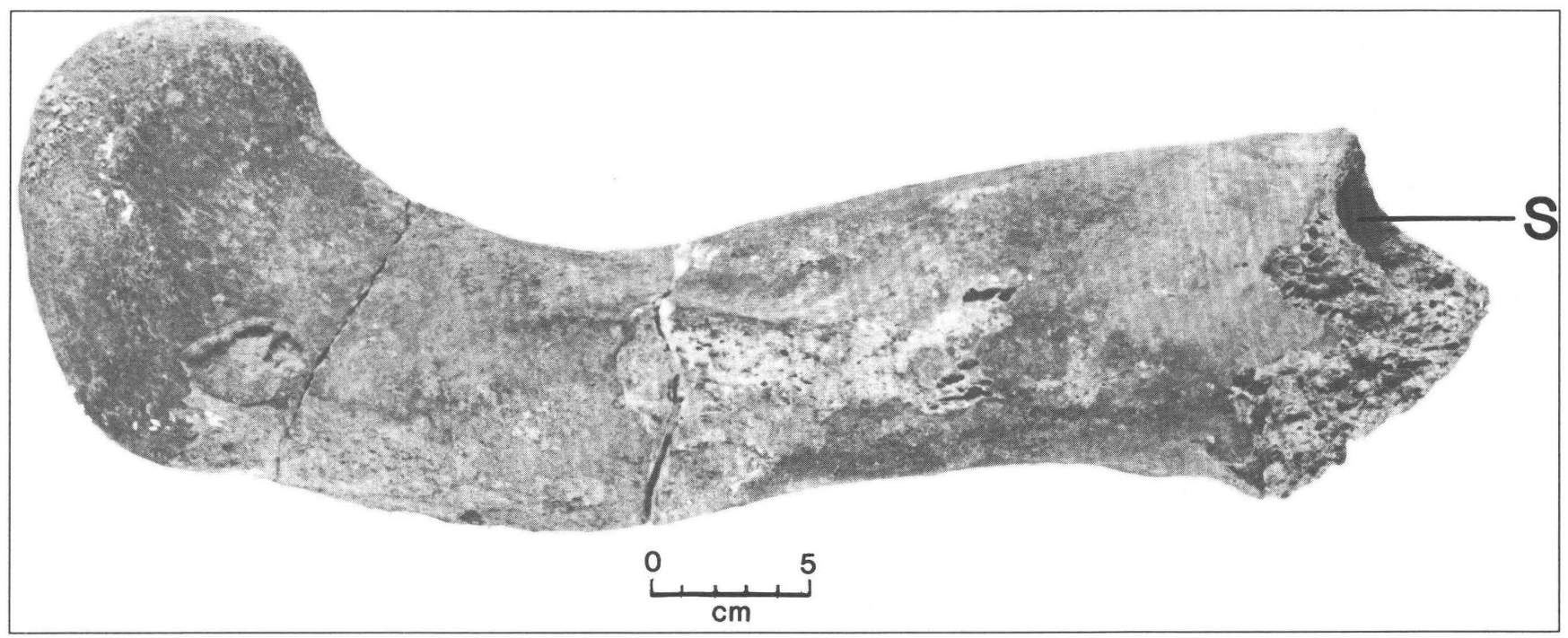

Figure F34. Rhabdognathus sp., no. 3-CR-3. Pathological left femur. S, large necrotic sinus in amputated distal shaft. 
The remainder of this end exposes the spongy interior of the base. It is possible the animal survived for a time after amputation occurred.

Buffetaut (1983) has reported evident lesions in the rostrum of a middle Eocene dyrosaur, Tilemsisuchus lavocati, which he attributes to injuries received during intraspecific fighting. The hypertrophy of the distal part of the femur suggests, however, that the lesions in no. 3-CR-3 resulted from a pathological condition of some duration and loss of the distal leg was not in this instance a direct result of trauma.

\section{GASTROLITHS}

Several smooth irregular quartzite pebbles were found in the pelvic region of the articulated skeleton no. 37-CR-1. The largest pebble has principal diameters of 97 and $82 \mathrm{~mm}$ and weighs $380 \mathrm{~g}$. All edges and corners are rounded off and some of the faces of the stones carry a dull polish, but chatter marks are not evident. Such rocks are not native to the Umm Himar Formation or to the surrounding terrain, so it is presumed that the pebbles are gastroliths.

\section{COPROLITES}

About a dozen coprolites were found at locality 37. Shapes include oval, discoidal, irregular, and kidney shaped (see Hantzschel and others, 1968). Most specimens resemble coprolites of carnivorous mammals. A few show evidence of compaction in the intestinal tract. They range from about 12 to $32 \mathrm{~mm}$ in diameter. A somewhat larger example thought to be from locality 1 is $38 \mathrm{~mm}$ in diameter. The coprolites vary in color from ivory to dark purple-brown and are generally lighter around the exterior than internally. The masses are very dense and compact, and they display a strong tendency toward conchoidal and flinty fracture into flakes, sometimes resembling chert. Faint random striations and short gouges on the surface of a number of the specimens are of unknown origin, but some may be evidence of arthropod or insect activity. All specimens contain small gas vugs, which are most abundant toward the outer surfaces. At least three of the coprolites contain quantities of finesand size green clay pellets, and in one these pellets made up a significant part of the mass. The pellets are well rounded and may represent remnants of pieces of shale ingested by accident or as gastroliths. One specimen contains a small localized mass of comminuted fish bones. Otherwise the fecal masses are devoid of recognizable organic structures. This is consistent with their assignment to the Crocodilia in which most organic material is destroyed by powerful gastric juices during digestion.

\section{SIZE, SKELETAL RECONSTRUCTION, AND INTERPRETATION}

The Saudi Arabian dyrosaurs display a considerable range in size. The smallest individuals, represented by isolated fragments of vertebrae, limb bones, and rostra were only about half as big as the largest examples in the collection. Buffetaut $(1979,1980)$ has estimated the lengths of various dyrosaurs up to 6-7 $\mathrm{m}$, based on Wermuth's proportional tables for recent crocodiles (Wermuth, 1964). Thevenin (1911) estimated the average length of Dyrosaurus at 5-6 m. Such estimates depend on the presumption that the body proportions were similar to those in better known fossil and recent longirostrine taxa, presently an uncertain proposition. All that can be said of Rhabdognathus sp. from Saudi Arabia is that some individuals were near the upper limits of size for known dyrosaurs, and they may have exceeded the length of $R$. rarus estimated by Buffetaut (1980) as around $4.5 \mathrm{~m}$; the proximal end of a tibia figured by Thevenin (1911, pl. XVI, fig. 6) is, however, about 30 percent larger than the largest tibia from Saudi Arabia (no. 60-CR-7), and a femur (pl. XVI, fig. 5) is even larger, surpassing the femur of no. $37-\mathrm{CR}-1$ by at least 40 percent. The distal end of a massive humerus (no. 43-CR-2) is about 20 percent larger than the same part of the humerus of Hyposaurus bequaerti figured by Swinton (1950, pl. VI). If the proportions were the same, this humerus would have been about $355 \mathrm{~mm}$ long.

Figure F35 is a generalized reconstruction based upon the Rhabdognathus sp. specimens described above, supplemented by published data from Dyrosaurus, Hyposaurus and other Rhabdognathus material. Mistakes, particularly in scaling and detail, are inherent in this kind of reconstruction, but I believe the drawing conveys a reasonable impression of the slender-snouted (hyposaurine) dyrosaur skeleton. Areas of uncertainty include the heights of the neural spines, lengths of the ribs, and the proportions of the forearm and forefoot (which are virtually unknown). The number of caudal vertebrae and arrangement of the chevrons is conjectural. The superior part of the scapula is drawn from Hyposaurus; the skull and jaw are largely from Dyrosaurus after Thevenin, with proportions adjusted to match Rhabdognathus, after Buffetaut.

The skeleton is depicted in semiprone resting pose with the head in alert position, a stance no doubt achieved either on land or while resting on the bottom of a body of water. The piscivorous habits attributed to Dyrosaurus are unquestioned, but the body movements involved in swimming and capture of prey can only be surmised. Axial flexibility may have been more restricted in the trunk than in their present day analogues Gavialis and Tomistoma owing to relatively heavier and more extensive and better articulated dorsal armor, to the amphiplatyan vertebral centra, and to the broad and closely spaced transverse processes in the thoracic series. Allocation of 14 vertebrae to the thoracic 
series (6 more than in eusuchians) and reduction of the length of the lumbar series are consistent with this interpretation. The neck on the other hand may have been more flexible, especially in the sagittal plane. This is suggested not only by the suspected absence of nuchal shields, the wedge-shaped cervical centra, and marked inclination of the zygapophyseal articulations, but also by the triangular cervical neural spines and massive but relatively posterior hypapophyses. Indeed, the articulated spinal column of a dyrosaur from Pakistan (Storrs, 1986) appears to have the neck bent more strongly backward than is possible even in a dried skeleton of any existing crocodilian.

Buffetaut (1982), noting the transversely expanded occipital condyle and the broad elevated occipital surfaces for the cervical flexor muscles, concluded that the head had a greater range of motion in the sagittal plane in dyrosaurs than in existing eusuchians, which have more hemispherical condyles. This is consistent with the above mechanical interpretation of the neck. With reduced lateral and torsional components it seems less likely that the dyrosaurs could indulge the common eusuchian (except gavials) practice of picking up objects with the side of the mouth.

Buffetaut (1982) regarded the mainly vertical rotation of the head as evidence of a diving habit analogous perhaps to cetaceans, but this is not so obvious to me. Although a seemingly less efficient maneuver, it is conceivable that in capturing fish the dyrosaurs threw their heads up and down rather than striking from side to side as gavials mainly do. This could also help in breaking, dismembering, and swallowing prey.

Although many neural spines are preserved in the Saudi Arabian collection, only a few remain attached to their respective vertebrae. The heights of the spines in the reconstruction are based largely on the articulated presacral column described by Storrs (1986), and on data from Swinton (1950) for Hyposaurus bequaerti. Anterior caudal spines are, however, somewhat lower than indicated for $H$. bequaerti because it was not possible to reach the two-fold increase in height from the known height of the third lumbar spine in no. 37-CR-1 without creating an unreasonably sudden change in the dorsal profile of the pelvic region.

High neural spines have long been recognized as a distinctive feature of Dyrosaurus and presumably of other dyrosaurs. However, only a few spines in the shoulder region and in the tail are greatly hypertrophied. Cervical spines are a little higher in relation to their respective centra than in some existing eusuchians (the seventh neural arch of no. 37-CR-1 is slightly more than 2.5 times as high as its centrum compared to about 2.25 times in a large Crocodylus acutus).

It has been assumed that, like existing crocodiles, the dyrosaurs propelled themselves in the water by lateral undulations of the body and tail. Although I have drawn the tail in a conventional fashion, the wedging of the caudal centra suggests some downward bending of the tail, though 
nothing approaching the condition in Geosaurus should be inferred. The uniquely lengthened spines may have provided support for a vertical finlike structure. The long and distinctively broadened tail therefore probably furnished the forward thrust in swimming. The relatively inflexible trunk was evidently narrower than in living eusuchians, to judge from the short thoracic transverse processes. Perhaps this served somehow as a vertical stabilizer, opposing the lateral torque generated by the swimming tail.

The limb proportions are puzzling. Usually in amphibious crocodilians and particularly in marine mesosuchians the forelimbs are substantially shorter than the hindlimbs. Although the relative lengths of the limbs have not been recorded in dyrosaurs, the humerus is almost as long as the femur in Hyposaurus bequaerti and the humerus to femur ratio is 93 in H. rogersii (YPM 985). Among existing crocodilians the ratio ranges from 60 to 104, with the largest value occurring only in an immature Crocodylus porosus cited by Knusel (1944). Moreover, the humerus in the Saudi Arabian Rhabdognathus sp. seems remarkably massive. The functional significance of the relatively powerful forelimbs is not clear, but such a departure from the usual conditions in marine crocodiles suggests that dyrosaur ancestors should be sought among Jurassic and Early Cretaceous terrestrial mesosuchians, which are but poorly known. The massive conditions of the tarsals and metatarsals are consistent with this conclusion.

\section{STRATIGRAPHIC IMPLICATIONS}

Fossil crocodilians are generally not very helpful in stratigraphic correlation because of the relative longevity of genera and inadequate definition of most species. The Dyrosauridae, however, are known to have existed from late Maastrichtian to late Eocene times. Indeed, it was the dyrosaur remains at Jabal Umm Himar that first indicated that the rocks of the Umm Himar Formation were older than "probable Pliocene," as originally reported by Gonzales (1973). Among dyrosaurs most resembling the Saudi Arabian forms, Phosphatosaurus ranges from the upper Maastrichtian into the Ypresian, in which it is best represented. Rhabdognathus rarus, which seems very similar to the most abundant Saudi Arabian species, is known from the upper Paleocene Dange Formation of Sokoto Province in Nigeria and from Paleocene beds in Mali. Rhabdognathus compressus and Hyposaurus nopcsai, the only species positively identified in the Saudi Arabian collection, are found also in Paleocene rocks in Mali and Sokoto Province, most probably from the Dange Formation. It seems likely, therefore, that the Umm Himar Formation was deposited at about the same time as the Dange Formation, bearing in mind the limited resolution possible from the dyrosaur material present in these units.
There has been some controversy about the age of the Dange Formation and the fossil vertebrate remains from the Wurno area (Kogbe 1973, 1974, 1981; Halstead, 1979). Originally believed to be Eocene (Nopcsa, 1925), the deposits were identified as probably Landenian, hence late Paleocene, by Swinton (1930) on the basis of the dyrosaur fossils themselves, which had all been found in talus near the village of Wurno. Petters (1978) assigned the Dange Formation to the Thanetian on the basis of contained Foraminifera.

This study of the Saudi Arabian dyrosaurs confirms the preliminary findings by Madden and others (1979), that vertebrate-bearing deposits of the Umm Himar Formation are of Paleocene age. The strong resemblance between the dyrosaurs of the Umm Himar and the Dange Formations further suggests that the Umm Himar beds may be assigned to the upper Paleocene. This conclusion is consistent with that based on stratigraphic ranges of Ceratodus humei and the siluriform fishes (Madden and others, Chap. A, this volume).

\section{PALEOGEOGRAPHIC IMPLICATIONS}

Until Buffetaut (1976a) redefined the Dyrosauridae, the group was believed to have been restricted to North Africa. With the recognition of the Late Cretaceous Hyposaurus as a dyrosaur, however, the range was extended to North and South America (Buffetaut, 1976b). With the later discovery of dyrosaurs in Pakistan and Burma, the family is seen to have had a southern Tethyan distribution. Indeed, Buffetaut (1982) has proposed the new infraordinal name Tethysuchia for the family Dyrosauridae.

Dyrosaurs are generally regarded as marine crocodilians whose principal habitats were restricted to coastal and estuarine environments. Only recently have dyrosaur remains been encountered in nonmarine deposits (Buffetaut, 1978b, 1978c). These occurrences are comparatively late in dyrosaurian history (middle to late Eocene) and may represent retreat of relict species into fresh water just prior to extinction. It is possible, however, that the group was more euryhaline than the fossil evidence suggests, because Upper Cretaceous and Paleocene continental vertebratebearing deposits that might contain dyrosaur remains are all but unknown in Africa, for example (Buffetaut, 1978c). The wide variety of shark and pycnodont remains associated with the dyrosaur bones around Jabal Umm Himar, however, leaves little doubt that the fossiliferous ferruginous claystones here were deposited under marine influences (Madden and others, 1979; Chap. A, this volume). But, as those authors note, the presence of Ceratodus humei in the deposits indicates closeness of fresh water, if only seasonally. The presence of Rhabdognathus, Hyposaurus, and ?Phosphatosaurus in the Umm Himar Formation seems consistent with the conclusion that the paleoenvironment in 
the Jabal Umm Himar area was estuarine instead of lacustrine as supposed by Gonzales (1973). The lithology of the rocks associated with the bone-bearing strata (see Madden and others, Chap. A, this volume) suggests a less welldrained environment than is indicated by the gypsum-rich, thin-bedded shales of the dyrosaur-bearing Dange Formation in Nigeria - which are interpreted as tidal flat deposits (Petters, 1978) and as a "transitional facies equivalent of the open marine calcareous Kalambaina Formation" by Kogbe (1981).

Prior to the joint USGS-Saudi Arabian work, the Late Cretaceous and early Paleogene sedimentary history of the western edge of the Arabian Peninsula was not well known (see Powers and others, 1966). Current paleogeographic reconstructions of the region appear to show only land here during Paleocene time (for example, see Smith, Hurley, and Briden, 1981; Barron and others, 1981). The Umm Himar fossils may therefore indicate slower than suspected retreat of the Maastrichtian Red Sea embayment of the southern Tethys (see Sander, 1970), and the persistence of a coastal connection along a northern African shelf between western Arabia and the West African seaway as recently as the late Paleocene. Perhaps this would extend the eastern edge of the Paleocene embayment a little farther east and south across Egypt than is indicated in Petters' paleogeographic reconstruction (Petters, 1978, fig. 9).

\section{REFERENCES}

Arambourg, Camille, 1952, Les vertébrés fossiles des gisements de phosphates (Maroc-Algérie-Tunisie): Service des Mines du Marco, Rabat, Notes et Mémoires, 92, 372 p.

Barron, E.J., Harrison, C.G.A., Sloan II, J.L., and Hay, W.W., 1981, Paleogeography, 180 million years ago to the present: Ecologae Geologicae Helvetiae, v. 74, no. 2, p. 443-470.

Bergounioux, F.M., 1955, Les crocodilians fossiles des dépôts phosphatés du Sud-Tunisien: Comptes-rendus de l'Académie des Sciences (Paris) Rt. 240, no. 19, 1917-1918.

Brinkman, D., 1981, The origin of the crocodyloid tarsi and the interrelationships of thecodontian archosaurs: Breviora no. 464, p. 1-23.

Buffetaut, Eric, 1975, Sur l'articulation entre le quadratojugal et le surangulaire de certains crocodiliens fossiles: Comptesrendus de l'Academie des Sciences, Paris, v. 280, p. 2741-2743.

1976a, Une nouvelle definition de la famille des Dyrosauridae de Stefano, 1903 (Crocodylia, Mesosuchia) et ses consequences: inclusion des genres Hyposaurus et Sokotosuchus dans les Dyrosauridae. Geobios, v. 9, p. 333-336.

1976b, Sur la répartition géographique hors d'Afrique des Dyrosauridae, crocodiliens mésosuchiens du Crétacé terminal et du Paléogène: Comptes-rendus de l'Academie des Sciences, Paris, v. 283D, p. 487-490.

1978a, Les Dyrosauridae (Crocodylia, Mesosuchia) des phosphates de l'Eocene inférieur de Tunisie: Dyrosaurus,
Rhabdognathus, Phosphatosaurus. Provence, Université, Annales, Géologie Méditerranéene, v. 5, no. 2, p. 237-256.

1978b, A dyrosaurid (Crocodylia, Mesosuchia) from the Upper Eocene of Burma: Neues Jahrbuch für Geologie und Paläntologie, Monatshefte, v. 5, p. 273-281.

1978c, Crocodilian remains from the Eocene of Pakistan: Neues Jahrbuch für Geologie und Paläntologie, Abhandlungen, v. 156 , no. 2 , p. $262-283$.

1979, Sokotosuchus ianwilsoni and the evolution of the dyrosaurid crocodilians: Nigerian Field, Monograph, v. 1, p. $31-41$.

1980, Les crocodiliens paleogenes du Tilemsi (Mali), un aperçu systematique: Palaeovertebrata, Mémoires Jubil R. Lavocat, p. 15-35.

1982, Radiation évolutive, paléoécologie et biogéographie des crocodiliens mésosuchiens: Mémoires de la Société Géologique de France, N.S. 60, Memoir 142, p. 1-88.

-1983 , Wounds on the jaw of an Eocene mesosuchian crocodilian as possible evidence for the antiquity of crocodilian intraspecific fighting behavior: Paläontologische Zeitschrift, v. 57 , p. 143-145.

Crompton, A.W., and Smith, K.K., 1980, A new genus and species of crocodilian from the Kayenta Formation (Late Triassic?) of northern Arizona, in Jacobs, L.L., ed., Aspects of vertebrate history, Flagstaff, Museum of Northern Arizona Press, p. 193-217.

Cruickshank, A.R.I., 1979, The ankle joint in some early archosaurs: South African Journal of Science, v. 75 , no. 4, p. $168-178$.

Dollo, L., 1914, Sur la découverte de Téléosauriens tertiares au Congo: Académie Royale des Sciences, des lettres et des beaux-arts de Belgique, Bulletin, p. 288-298.

Gonzalez, Louis, 1973, Geologic map and section of the Jabal 'In quadrangle: Saudi Arabian Directorate General of Mineral Resources Geologic Map GM-2, 7 p.

Halstead, L.B., 1979, Type sections of the Cretaceous-Tertiary transition of Sokoto: Nigerian Field Monograph, no. 1, p. $50-63$.

Halstead, L.B., and Middleton, J., 1976, Fossil vertebrates of Nigeria, Part III: The Nigerian Field, no. 41, p. 166-174.

Hantzschel, W., El-Baz, F., and Amstutz, G.C., 1968, Coprolites, an annotated bibliography: Geological Society of America Memoir 108, $132 \mathrm{p}$.

Hecht, M.K., and Tarsitano, S.F., 1983, The tarsus and metatarsus of Protosuchus and its phyletic implications, in Rhodin, A.G.J., and Myata, Kenneth, eds., Advances in herpetology and evolutionary biology: Cambridge, Mass., Museum of Comparative Zoology, p. 332-349.

Hopson, J.A., 1979, Paleoneurology, in Gans, C., Northcutt, R.G., and Ulinski, P., eds., Biology of the Reptilia 9: London and New York, Academic Press, p. 39-146.

Iordansky, N.N., 1973. The skull of the Crocodilia, in Gans, C., and Parsons, T.S., eds., Biology of the Reptilia 4: Academic Press, London and New York, p. 201-262.

Knusel, P.L., 1944, Beitrage zur Morphologie und Funktion der Crocodiliden-Extremitaten: Sarnen, Louis Ehrli, 88 p.

Kogbe, C.A., 1973, Geology of the Upper Cretaceous and Tertiary sediments of the Nigerian sector of the Iullemeden Basin (West Africa): Geologische Rundschau, v. 62, no. 1, p. 197-211. 
1974, Palaeoecologic distribution of the vertebrate fossils in the Dukamaje and Dange Formations (Maestrichtian and Palaeocene) of North-Western Nigeria: Journal of Mining and Geology, Nigerian Mining and Geology Society, v. 8, p. 49-55.

-1981 , Cretaceous and Tertiary of the Iullemeden Basin in Nigeria (West Africa): Cretaceous Research, v. 2, p. $129-186$

Langston, W., Jr., 1973, The crocodilian skull in historical perspective, in Gans, C., and Parsons, T.S., eds., Biology of the Reptilia 4: London and New York, Academic Press, p. 263-284.

Lavocat, Rene, 1955, Observations anatomiques nouvelles sur le genre de crocodilien Dyrosaurus Pomel: Comptes-rendus de l'Académie des Sciences, Paris, v. 240, no. 26, p. 2549-2551.

Madden, C.T., Naqvi, I.M., Whitmore, F.C., Jr., Schmidt, D.L., Langston, Wann, Jr., and Wood, R.C., 1979, Paleocene vertebrates from coastal deposits in the Harrat Hadan area, At Taif Region, Kingdom of Saudi Arabia, U.S. Geological Survey Saudi Arabian Mission Project Report 269, 29 p.

Moody, R.T.J., and Buffetaut, E., 1981, Notes on the systematics and palaeoecology of the crocodiles and turtles of the Metlaoni Phosphates (Eocene) of southern Tunisia: Tertiary Research, v. 3, no. 3, p. 125-140.

Nopcsa, F., 1925, On some reptilian bones from the Eocene of Sokoto: Occasional paper of the Geological Survey of Nigeria, v. $2,15 \mathrm{p}$.

Owen, R., 1849, Notes on remains of fossil reptiles discovered by Prof. Henry Rogers, of Pennsylvania, U.S., in Green-sand formation of New Jersey: Quarterly Journal of the Geological Society of London, v. 5, p. 380-383.

Parris, D.C., 1986, Biostratigraphy of the fossil crocodile Hyposaurus Owen from New Jersey: New Jersey State Museum, Investigation no. 4, $16 \mathrm{p}$.

Petters, S.W., 1978, Ancient seaway across the Sahara: The Nigerian Field, v. 42 , p. 22-30.

1979, Stratigraphic history of the south-central Saharan region: Geological Society of America Bulletin, pt. I, v. 90, no. 8 , p. $753-760$.
Piveteau, Jean, 1935. Le Dyrosaurus crocodilien de l'Éocène inférieur de l'Afrique du Nord. Annales de Paléontologie, v. 24, p. 51-71.

Powers, R.W., Ramirez, L.F., Redmond, C.D., and Elberg, E.L., Jr., 1966, Geology of the Arabian Peninsula, Sedimentary geology of Saudia Arabia: U.S. Geological Survey Professional Paper 560-D, 147 p.

Ross, F.D., and Mayer, G.C., 1983, On the dorsal armor of the Crocodilia, in Rhodin, A.G.J., and Miyata, K., eds., Advances in herpetology and evolutionary biology: Cambridge, Mass., Museum of Comparative Zoology, p. 305-331.

Sander, N.J., 1970, Structural evolution of the Mediterranean region during the Mesozoic Era, in Sonnenfeld, Peter, ed., Tethys, the ancestral Mediterranean, 1981: Stroudsburg, Pa., Hutchinson Ross Publishing Co., p. 100-189.

Smith, A.G., Hurley, A.M., and Briden, J.C., 1981, Phanerozoic paleocontinental world maps: London, Cambridge University Press, $102 \mathrm{p}$.

Steel, Rodney, 1973, Crocodylia, Encyclopedia of Paleoherpetology: Stuttgart, G. Fischer Verlag, 116 p.

Storrs, G.W., 1986, A dyrosaurid crocodile (Crocodylia: Mesosuchia) from the Paleocene of Pakistan: Postilla 197, $16 \mathrm{p}$.

Swinton, W.E., 1930, On fossil Reptilia from Sokoto Province: Geological Survey of Nigeria Bulletins, v. 13, p. 9-61. 1950, On Congosaurus bequaerti Dollo: Annales du Musée du Congo Belge Tervuren (Belgique), Sciences Géologiques, v. 4, p. 9-34.

Thevenin, A., 1911, Le Dyrosaurus des Phosphates de Tunisie: Annales de Paléontologie, v. 6, p. 95-108.

Troxell, E.L., 1925, Hyposaurus, a marine crocodilian: American Journal of Science, v. 8, p. 489-514.

Wenz, Sylvie, 1968, Contribution a l'étude du genre Metriorhynchus Crâne et moulage endocranien de Metriorhynchus superciliosus: Annales de Paléontologie (Vertébrés), v. 54, no. 2, p. 149-183.

Wermuth, H., 1964, Das Verhaltnis zwischen Kopf-, Rumpf- und Schwanzlange bei den rezenten Krokodilen: Senckenbergiana Biologica, v. 45, p. 369-385.

Wettstein, O. von, 1937, Crocodilia, in Kukenthal, W., ed., Handbuch der Zoologie: Berlin and Leipzig, Walter de Gruyter and Co., 7/1 Sauropsida, p. 236-320. 


\section{SELECTED SERIES OF U.S. GEOLOGICAL SURVEY PUBLICATIONS}

\section{Periodicals}

Earthquakes \& Volcanoes (issued bimonthly). Preliminary Determination of Epicenters (issued monthly).

\section{Technical Books and Reports}

Professional Papers are mainly comprehensive scientific reports of wide and lasting interest and importance to professional scientists and engineers. Included are reports on the results of resource studies and of topographic, hydrologic, and geologic investigations. They also include collections of related papers addressing different aspects of a single scientific topic.

Bulletins contain significant data and interpretations that are of lasting scientific interest but are generally more limited in scope or geographic coverage than Professional Papers. They include the results of resource studies and of geologic and topographic investigations, as well as collections of short papers related to a specific topic.

Water-Supply Papers are comprehensive reports that present significant interpretive results of hydrologic investigations of wide interest to professional geologists, hydrologists, and engineers. The series covers investigations in all phases of hydrology, including hydrogeology, availability of water, quality of water, and use of water.

Circulars present administrative information or important scientific information of wide popular interest in a format designed for distribution at no cost to the public. Information is usually of short-term interest.

Water-Resources Investigations Reports are papers of an interpretive nature made available to the public outside the formal USGS publications series. Copies are reproduced on request unlike formal USGS publications, and they are also available for public inspection at depositories indicated in USGS catalogs.

Open-File Reports include unpublished manuscript reports, maps, and other material that are made available for public consultation at depositories. They are a nonpermanent form of publication that may be cited in other publications as sources of information.

\section{Maps}

Geologic Quadrangle Maps are multicolor geologic maps on topographic bases in 7.5- or 15-minute quadrangle formats (scales mainly 1:24,000 or 1:62,500) showing bedrock, surficial, or engineering geology. Maps generally include brief texts; some maps include structure and columnar sections only.

Geophysical Investigations Maps are on topographic or planimetric bases at various scales; they show results of surveys using geophysical techniques, such as gravity, magnetic, seismic, or radioactivity, which reflect subsurface structures that are of economic or geologic significance. Many maps include correlations with the geology.

Miscellaneous Investigations Series Maps are on planimetric or topographic bases of regular and irregular areas at various scales; they present a wide variety of format and subject matter. The series also includes 7.5-minute quadrangle photogeologic maps on planimetric bases that show geology as interpreted from aerial photographs. Series also includes maps of Mars and the Moon.
Coal Investigations Maps are geologic maps on topographic or planimetric bases at various scales showing bedrock or surficial geology, stratigraphy, and structural relations in certain coalresource areas.

Oil and Gas Investigations Charts show stratigraphic information for certain oil and gas fields and other areas having petroleum potential.

Miscellaneous Field Studies Maps are multicolor or blackand-white maps on topographic or planimetric bases for quadrangle or irregular areas at various scales. Pre-1971 maps show bedrock geology in relation to specific mining or mineral-deposit problems; post-1971 maps are primarily black-and-white maps on various subjects such as environmental studies or wilderness mineral investigations.

Hydrologic Investigations Atlases are multicolored or black-and-white maps on topographic or planimetric bases presenting a wide range of geohydrologic data of both regular and irregular areas; principal scale is 1:24,000, and regional studies are at $1: 250,000$ scale or smaller.

\section{Catalogs}

Permanent catalogs, as well as some others, giving comprehensive listings of U.S. Geological Survey publications are available under the conditions indicated below from the U.S. Geological Survey, Information Services, Box 25286, Federal Center, Denver, CO 80225. (See latest Price and Availability List.)

"Publications of the Geological Survey, 1879-1961" may be purchased by mail and over the counter in paperback book form and as a set of microfiche.

"Publications of the Geological Survey, 1962-1970" may be purchased by mail and over the counter in paperback book form and as a set of microfiche.

"Publications of the U.S. Geological Survey, 1971-1981" may be purchased by mail and over the counter in paperback book form (two volumes, publications listing and index) and as a set of microfiche.

Supplements for 1982, 1983, 1984, 1985, 1986, and for subsequent years since the last permanent catalog may be purchased by mail and over the counter in paperback book form.

State catalogs, "List of U.S. Geological Survey Geologic and Water-Supply Reports and Maps For (State)," may be purchased by mail and over the counter in paperback booklet form only.

"Price and Availability List of U.S. Geological Survey Publications," issued annually, is available free of charge in paperback booklet form only.

Selected copies of a monthly catalog "New Publications of the U.S. Geological Survey" are available free of charge by mail or may be obtained over the counter in paperback booklet form only. Those wishing a free subscription to the monthly catalog "New Publications of the U.S. Geological Survey" should write to the U.S. Geological Survey, 582 National Center, Reston, VA 22092.

Note-Prices of Government publications listed in older catalogs, announcements, and publications may be incorrect. Therefore, the prices charged may differ from the prices in catalogs, announcements, and publications. 
